Constança Maria Lima de Almeida Lucas

Desenho como palavra, desenho como imagem Experiências desenhadas

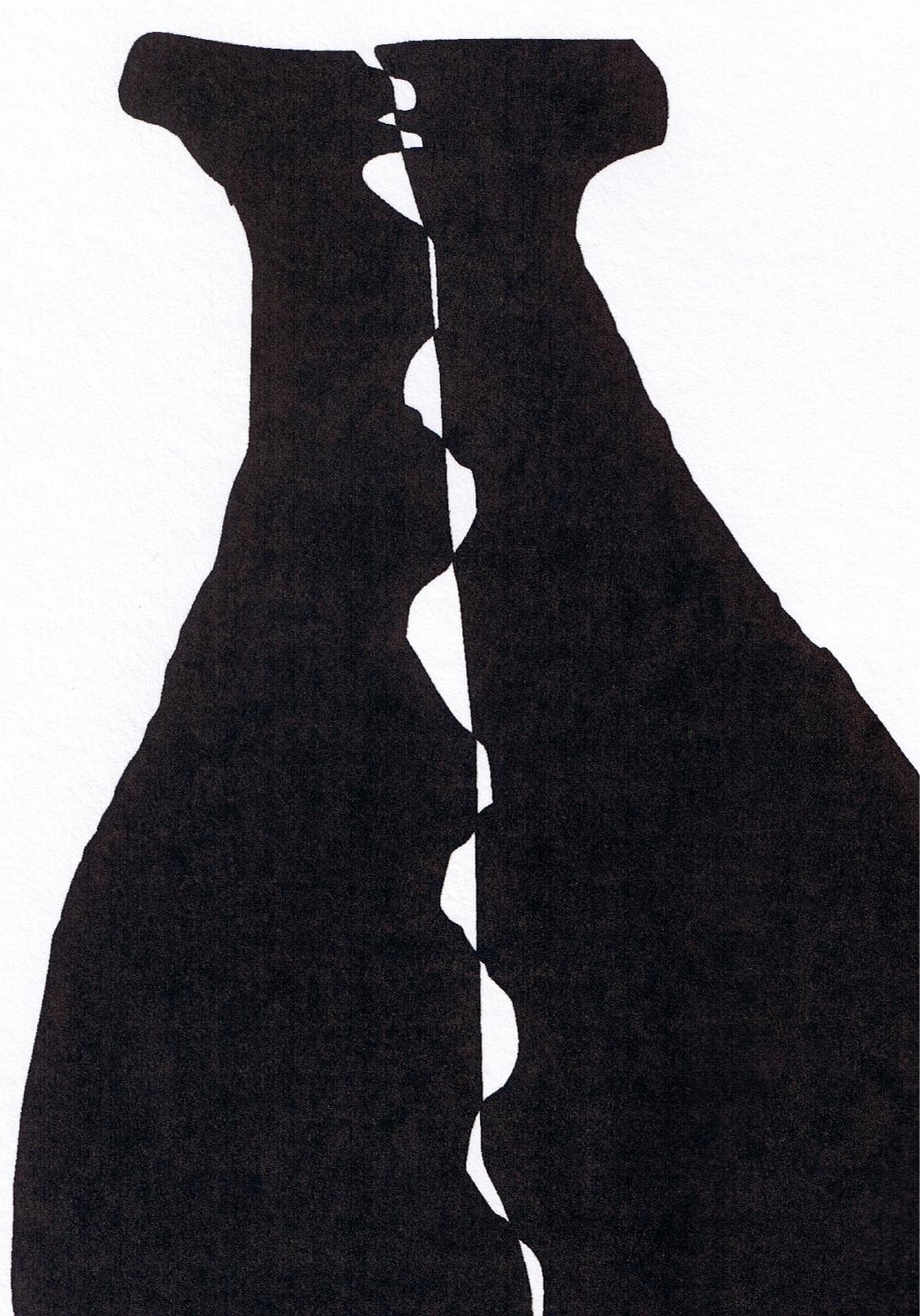




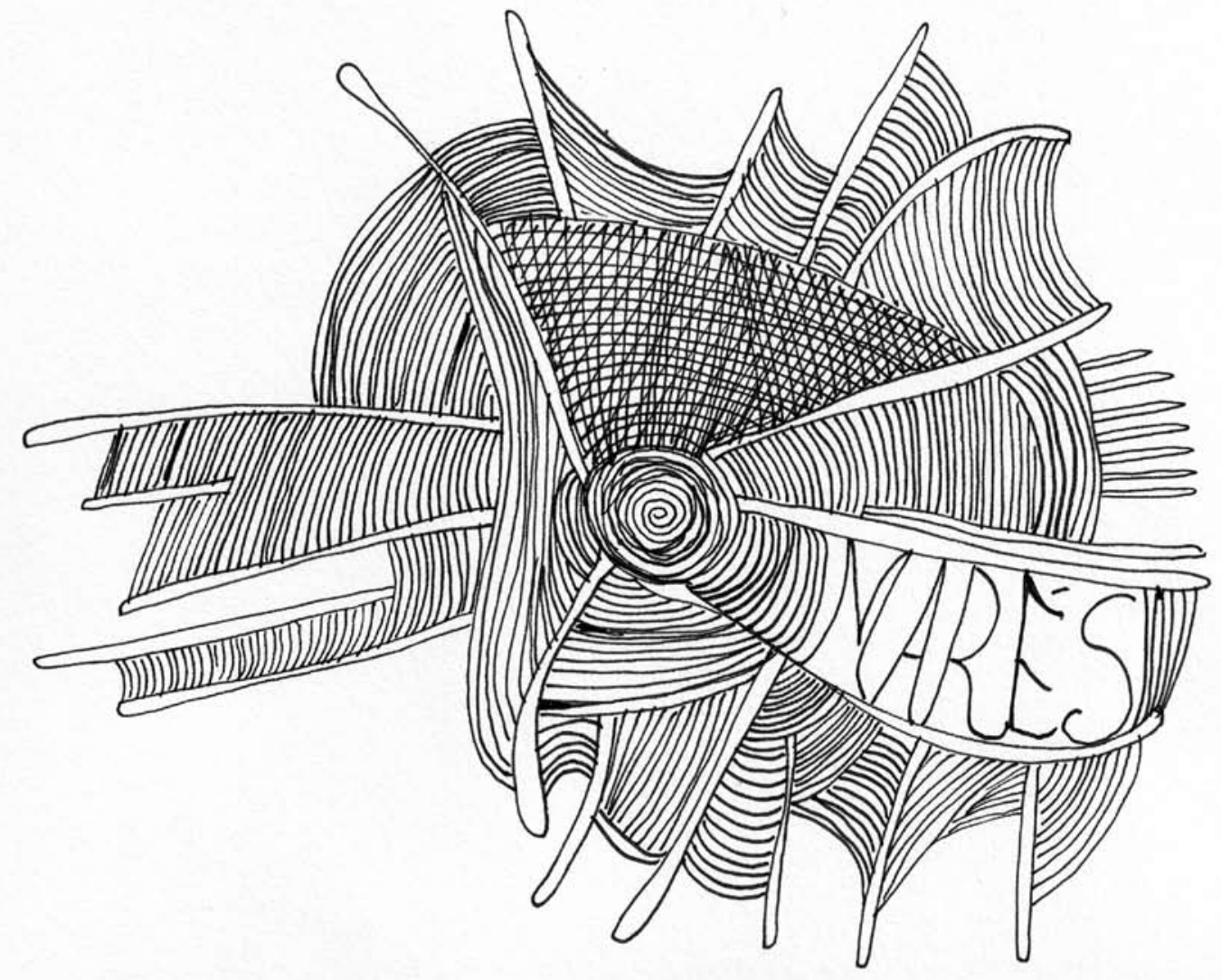



Constança Maria Lima de Almeida Lucas

\section{Desenho como palavra, desenho como imagem Experiências desenhadas}

Tese apresentada à Escola de Comunicações e Artes da Universidade de São Paulo como exigência parcial para a obtenção do título de Doutora em Artes Visuais

Área de Concentração: Poéticas Visuais Linha de Pesquisa: Processos de Criação em Artes Visuais

Orientador: Prof. Dr. Evandro Carlos Frasca Poyares Jardim

São Paulo, 2012 
Autorizo a reprodução total ou parcial deste trabalho por qualquer meio convencional ou eletrônico, para fins de estudo e pesquisa, desde que citada a fonte.

As 192 páginas deste volume foram impressas no papel color plus marfim $120 \mathrm{~g} / \mathrm{m}^{2}$. A fonte utilizada foi a Arial Narrow.

\section{Catalogação na publicação \\ Serviço de Biblioteca e Documentação \\ Escola de Comunicações e Artes da Universidade de São Paulo}

Lucas, Constança Maria Lima de Almeida

Desenho como palavra, desenho como imagem : experiências desenhadas /

Constança Maria Lima de Almeida Lucas - São Paulo : C. M. L. A. Lucas, 2012.

2 v. : il.

Tese (Doutorado) - Escola de Comunicações e Artes / Universidade de São

Paulo.

Orientador: Evandro Carlos Frasca Poyares Jardim

1. Desenho 2. Poesia visual 3. Livro de artista 4. Palavra e imagem 5. Poesia 6.

Artes visuais 7. Poéticas visuais I. Jardim, Evandro Carlos Frasca Poyares II. Título

CDD 21.ed. -700 
Banca examinadora 

Agradecimentos

Evandro Carlos Jardim

Rogério Carlos Gastaldo de Oliveira

CAPES - Coordenação de Aperfeiçoamento de Pessoal de Nível Superior 



\section{Resumo}

O meu projeto de pesquisa e criação artística tem como foco 0 desenho na minha produção pessoal. Desenhar como forma de pensamento, pensamento como ato de criação nos diários de desenhos, pinturas, gravuras, livros de artista, poemas visuais e cadernos de anotações, onde o desenho é palavra e imagem.

Palavras chave:

Desenho, poesia visual, livro de artista, palavra e imagem, poesia.

\section{Abstract}

The main focus of my research project and artistic creation is the drawing in my personal art work. To draw as a way of thinking, thinking as an act of creation in the drawing diaries, paintings, prints, artist books, and sketch-books, where the drawing is word and image.

Key words:

Drawing, visual poetry, artist book, word and image, poetry. 



\section{Sumário}

Desenho como palavra, desenho como imagem .................... 15

Poesia visual é partilha primordial............................................. 21

Poemas visuais em formato postal........................................... 57

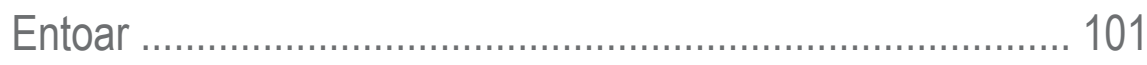

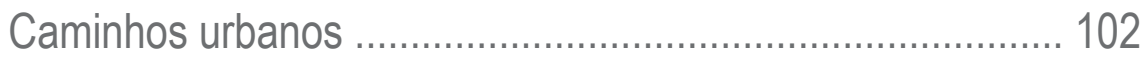

De quando em vez …........................................................ 103

As palavras mudam as batidas do coração a cada instante 123 Alinhavar sonhos .............................................................. 124

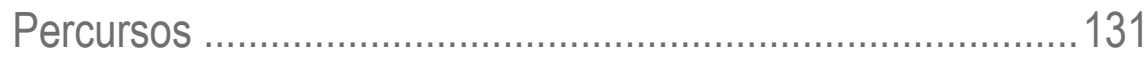

"O sonho é ver formas invisíveis" .......................................... 132

Desenhar ânforas é como entrar no mundo das demoras .... 146

Nos livros de artista experimento ......................................... 158

Tempo é pseudônimo de espera ........................................... 165

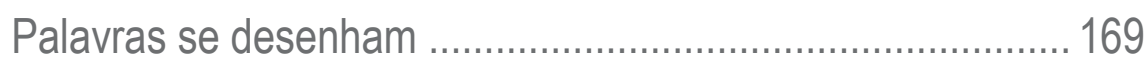

Onde as palavras nascem é segredo ................................... 173

Referências Bibliográficas ……………………………..... 181

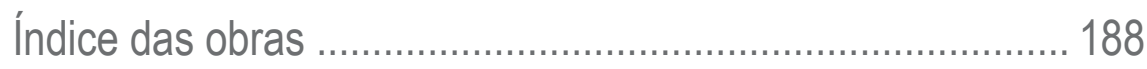

Anexo: Livro de Artista "Desenhar Hoje" 


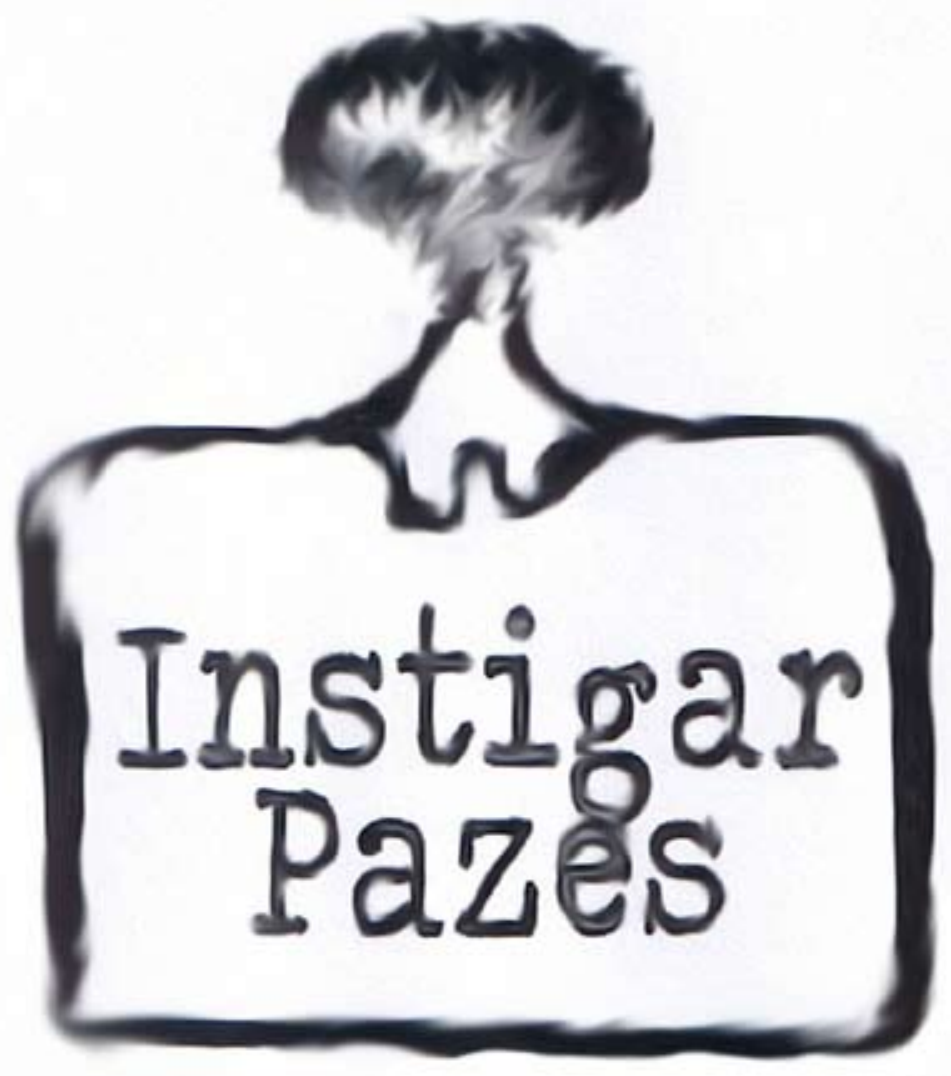




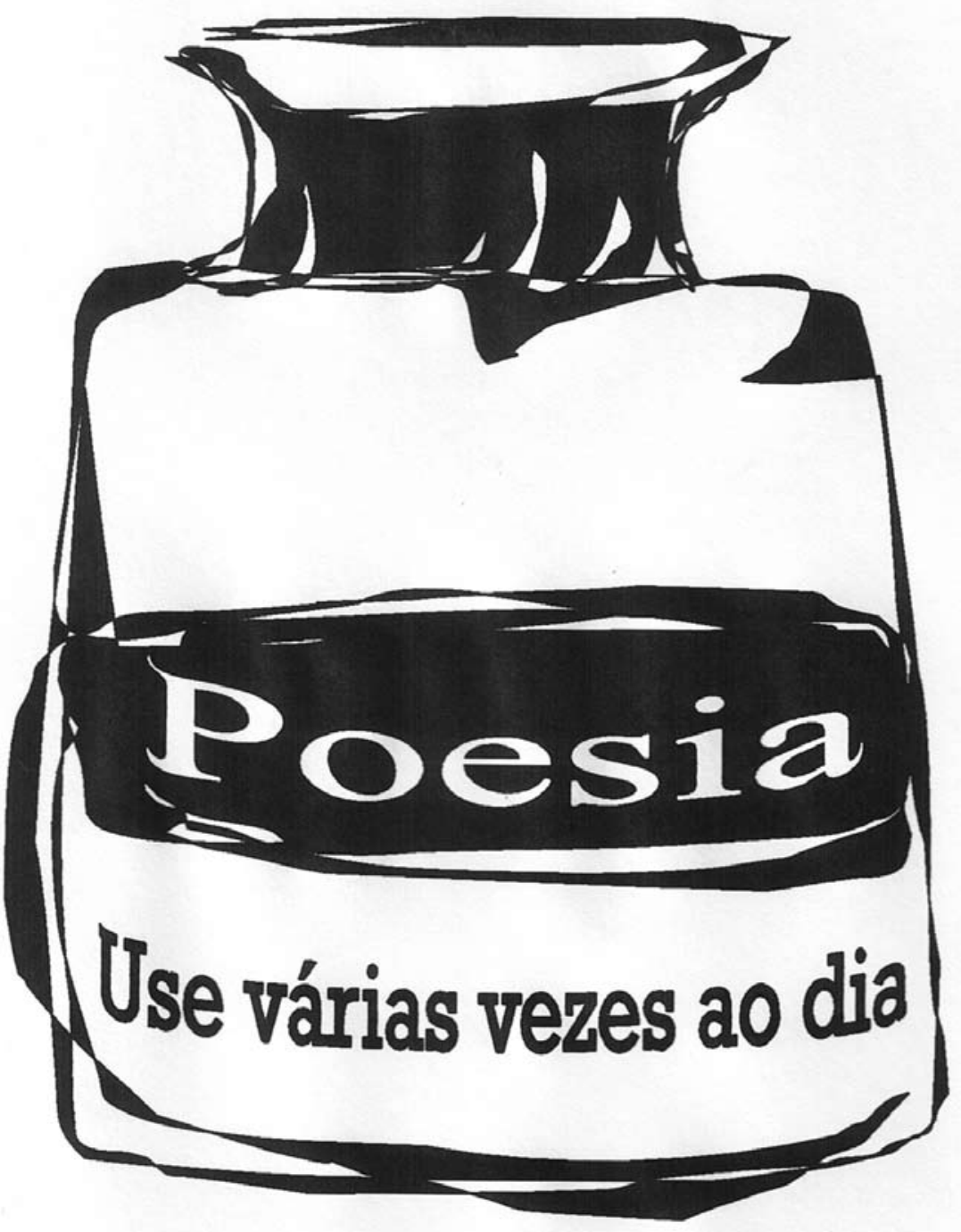




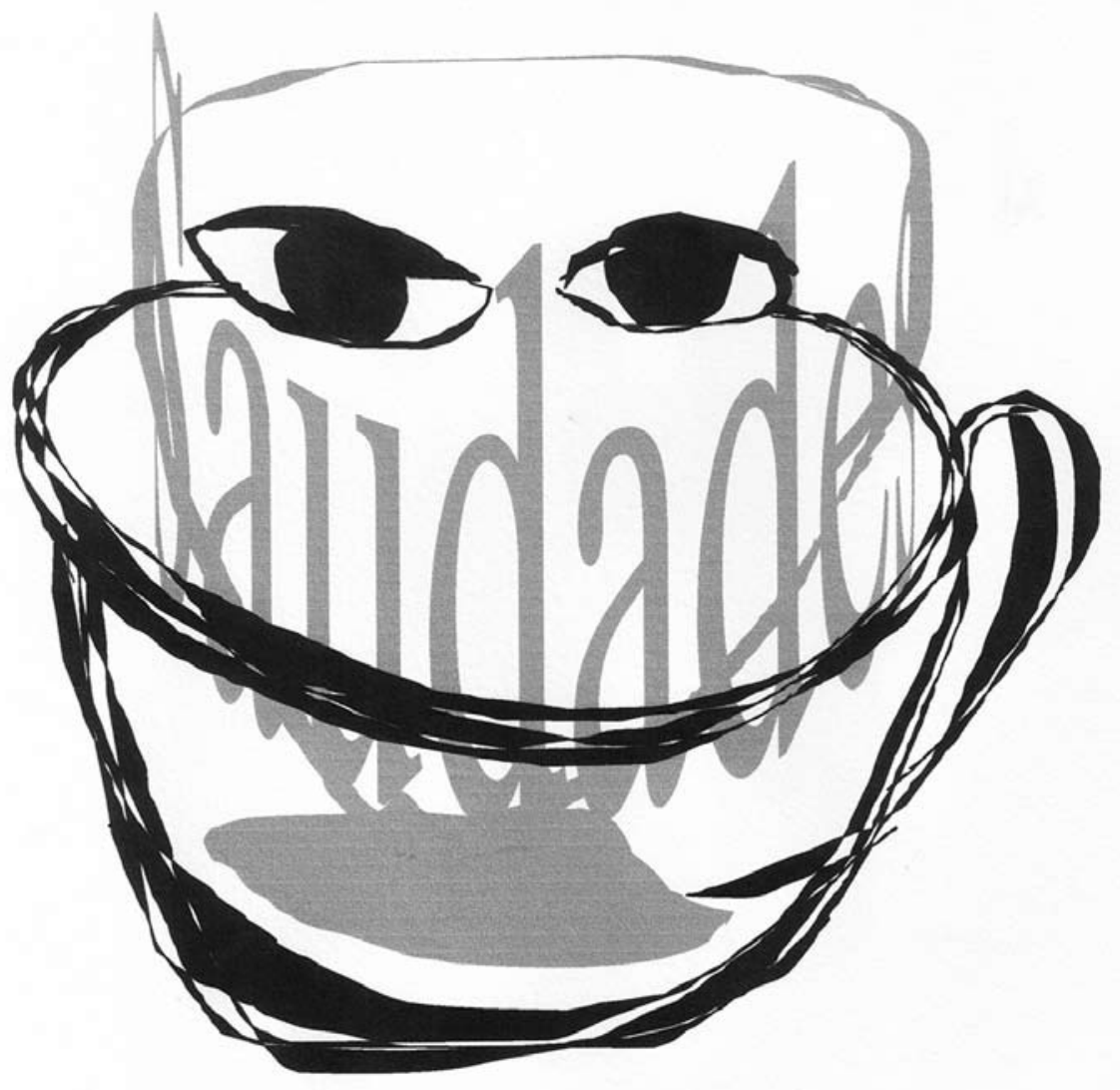




\section{Desenho \\ como palavra, \\ Desenho \\ como imagem.}

Ecoam em mim palavras desenhadas, melódicas, estridentes, telúricas, ausentes, gráficas, poéticas.

Palavras se recriam, dançam frases sopradas, calam, aprendem solidão, têm vozes entranhadas nas brisas, têm letras que adormecem no inverno seco, tropeçam nas folhas e gravam as flores das árvores distantes, no verão habitam frases onde as certezas 
se esvaem, não se lembram do rosto, nem do sal, moram na luz abraçada ao extremo do sonho onde nascem voos.

Palavras soam na memória longínqua de sorrisos e lágrimas, nos esquecimentos com sabores desenhados na maresia - inventam penumbras.

Palavras fazem frases invisíveis, criam rumores dentro das sílabas, exigem as sombras dos dias acariciados pelas cores e pelos ventos de linhas aguçadas onde estremecem canções internas - os corpos aquecem seu próprio canto, vozes passageiras reforçam o olhar soletrado até amanhecer.

Dentro das palavras caminho com 
pedras nos bolsos para não esquecer o traçado da viagem, e guardar a luminosidade das letras calcárias num horizonte pleno de cantigas de alento.

No lamento das ausências, desenhadas nas almas, nos poemas cantados, nas noites, nos amores adiados ou mortos - onde cada letra sorve as sílabas das vidas sonhadas ou desaparecidas - no mar o sal abraça as gargantas ao saber das lágrimas internas entoadas letra a letra num amar chamado fado.

No fado que é dado a alguns saber cantar, dança a voz em muitas notas para uma sílaba só, ornamentos melódicos com os poemas, fado que nos habita, ouvimos as vozes, com 
elas moramos, amamos mais longe, lamentamos o desconhecido, abraçamos docemente o bem querer do ser vivido, gostamos do fado para inventarmos amores e neles nos perdermos mares adentro, com as melismas a desenharem nossos saberes.

Nas paisagens guardadas, sons secretos, e mágicas formas emanadas dos granitos gravados pelos ventos seculares, rochas escultóricas, pedras habitantes com espelhos nas micas serranas.

As pedras desmoronam em convulsões, muros do cotidiano a cantarem experiências oníricas.

Obstinada e atenta observo as correntezas dos dias onde lapido 
dizeres, relato as folhas das palmeiras, observo os tons a balançarem ao vento, fotografo as nuvens fugidias, registro os estilhaços na paisagem sempre renovada.

Olho a cidade habitada com seus horizontes velozes, onde receptáculos, tais como vidros, frascos, ânforas, chávenas, caixas, etc., invadem os ritmos gráficos das paisagens do cotidiano. Desenho esses receptáculos de observação e de memória, recrio suas formas e reinvento seus contextos. Desenhos dos receptáculos e desenhos das palavras fundemse e formam poemas visuais, criando espaços de reflexão onde formas e conteúdos estão em plena sintonia. 


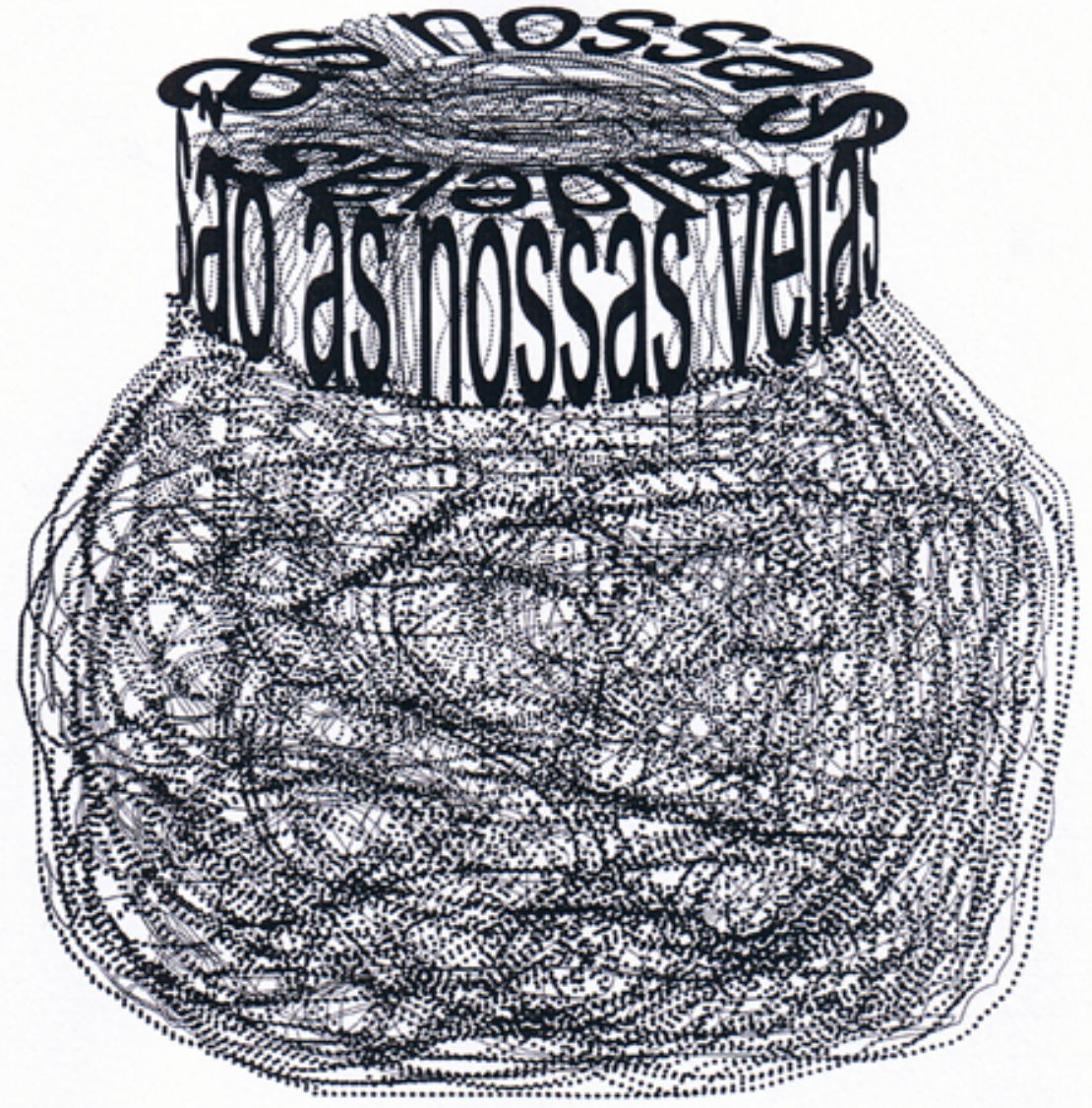


Poesia visual é partilha primordial

A poesia visual tem um espaço privilegiado dentro do meu trabalho artístico. A forma é ditada pela palavra e a palavra é forma. Estabeleço relações de intimidade gráfica e cultural entre a escrita e o desenhar.

A arte adquire sentidos mais amplos na esfera do sensível e da memória coletiva quando é partilhada.

Partilhei milhares de poemas visuais através do correio, os expus em diversas estações do metrô paulistano, foram publicados em livros, revistas, jornais culturais, redes sociais, sites, blogs e foram expostos em galerias, espaços públicos e ateliers.

Reúno aqui poemas visuais e desenhos realizados nos últimos quatro anos. 


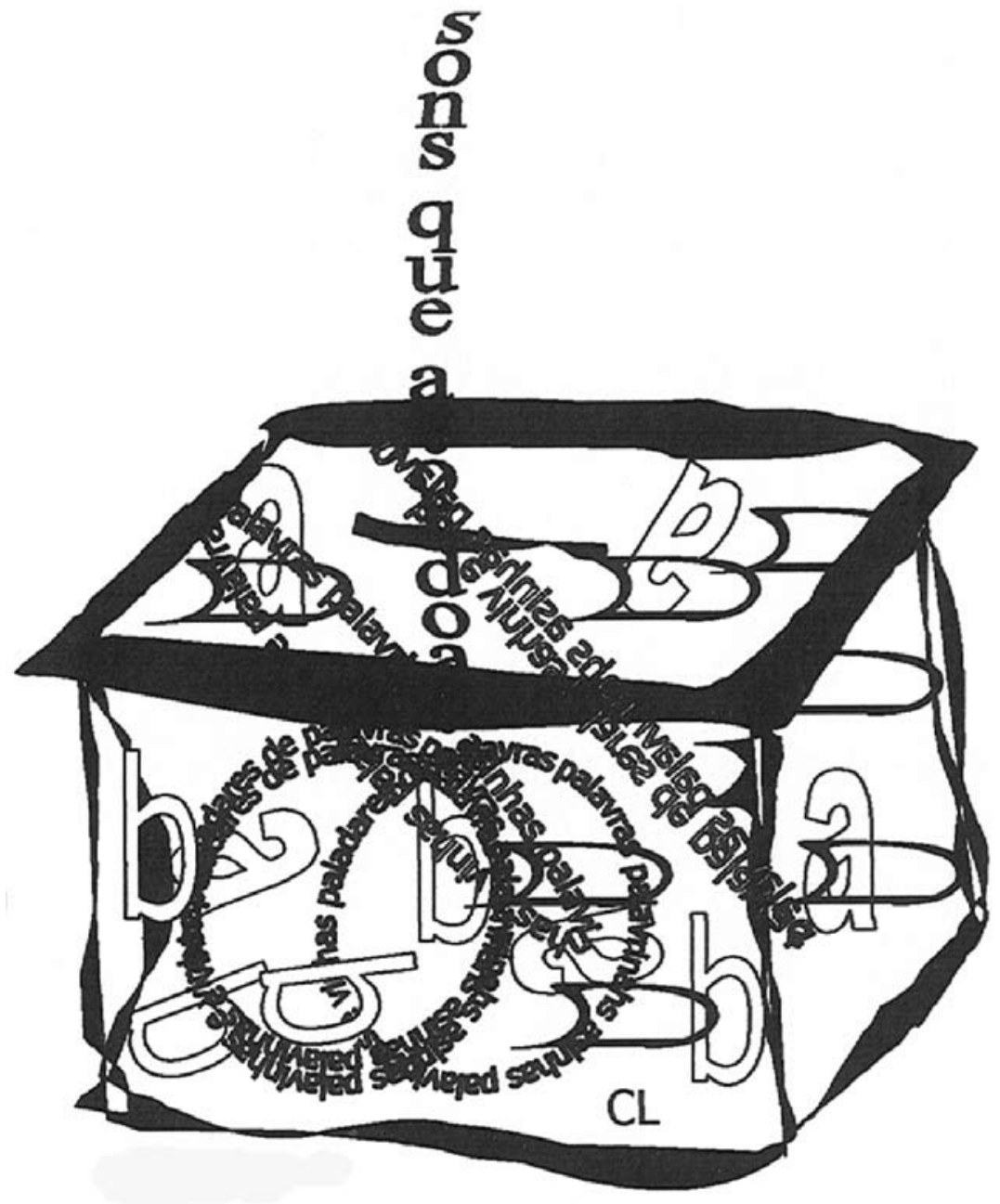




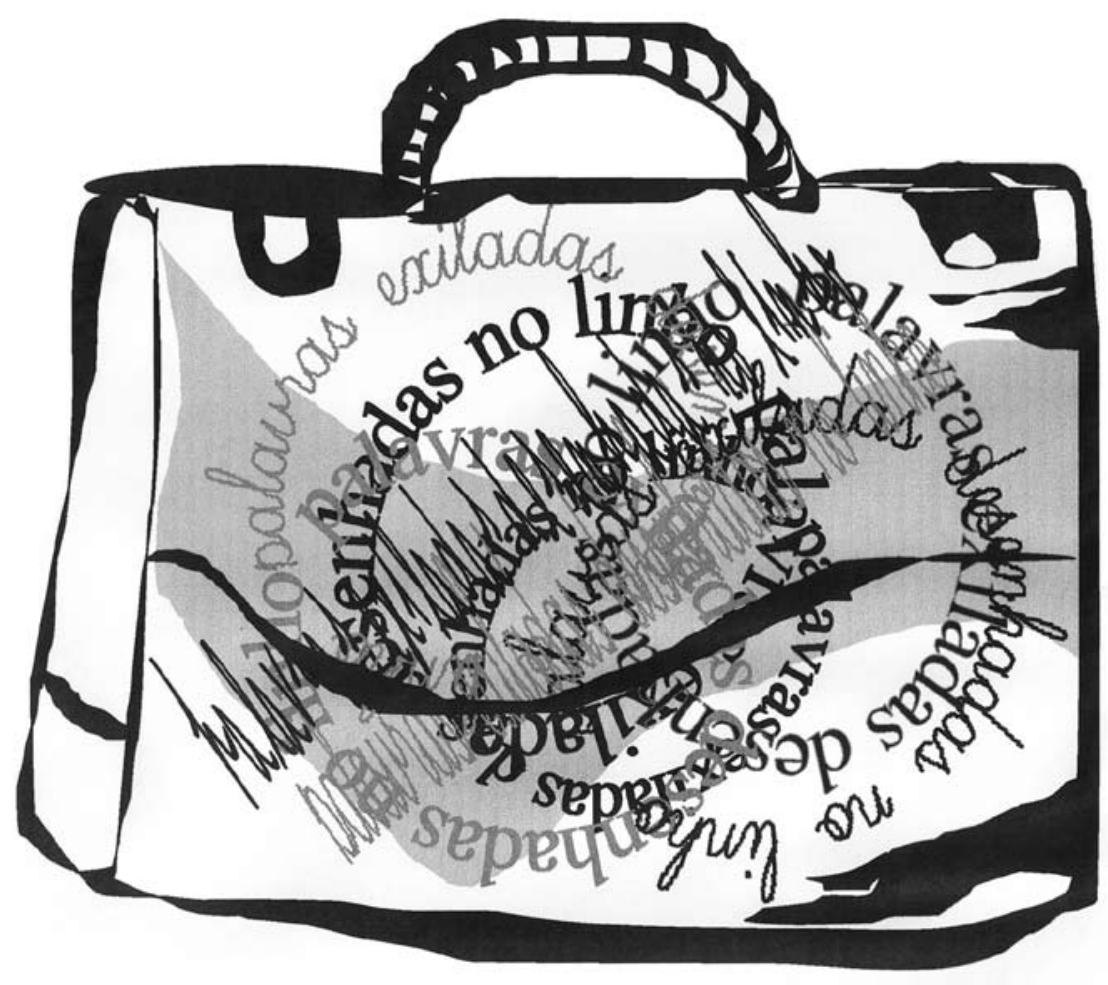




$$
8
$$




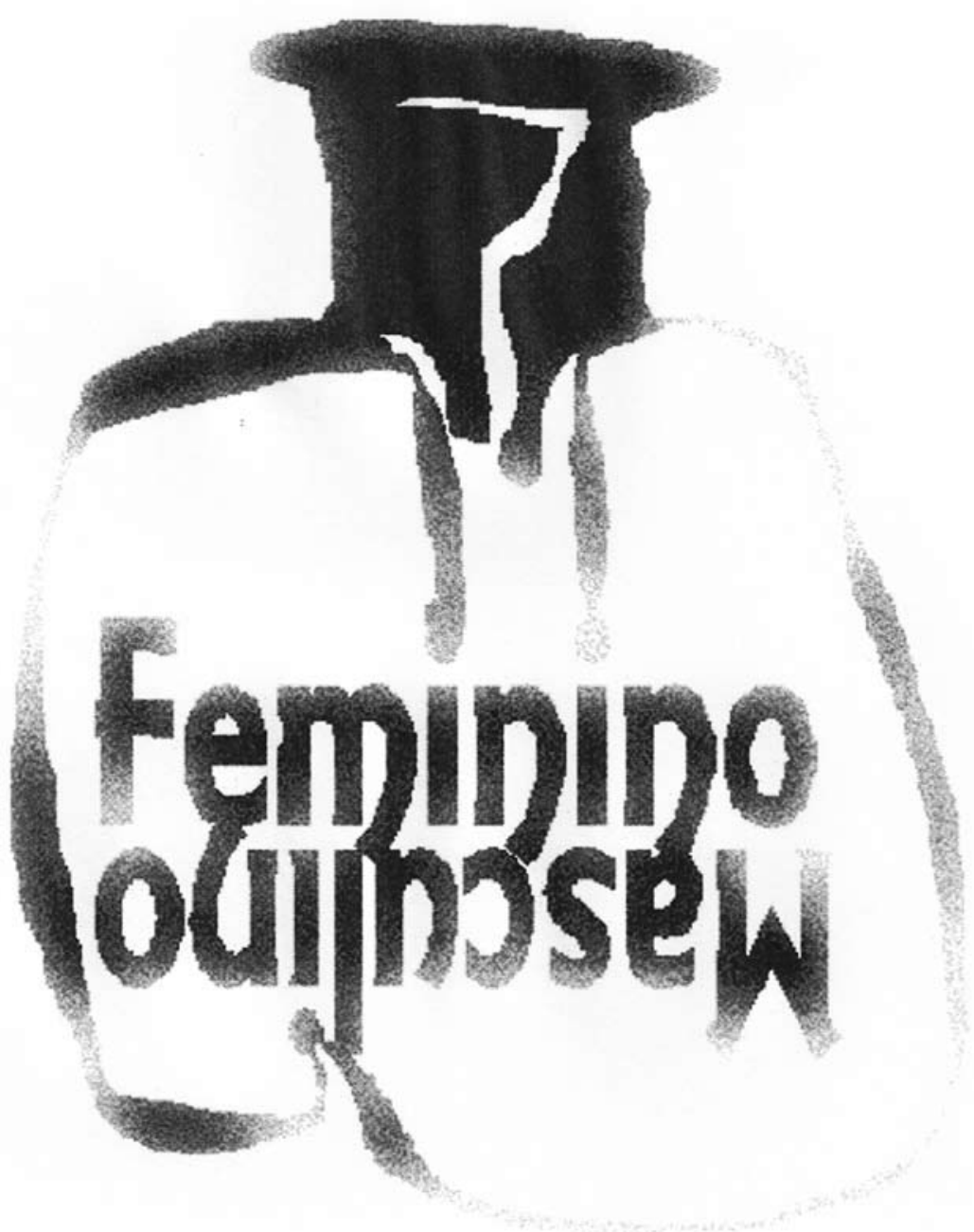




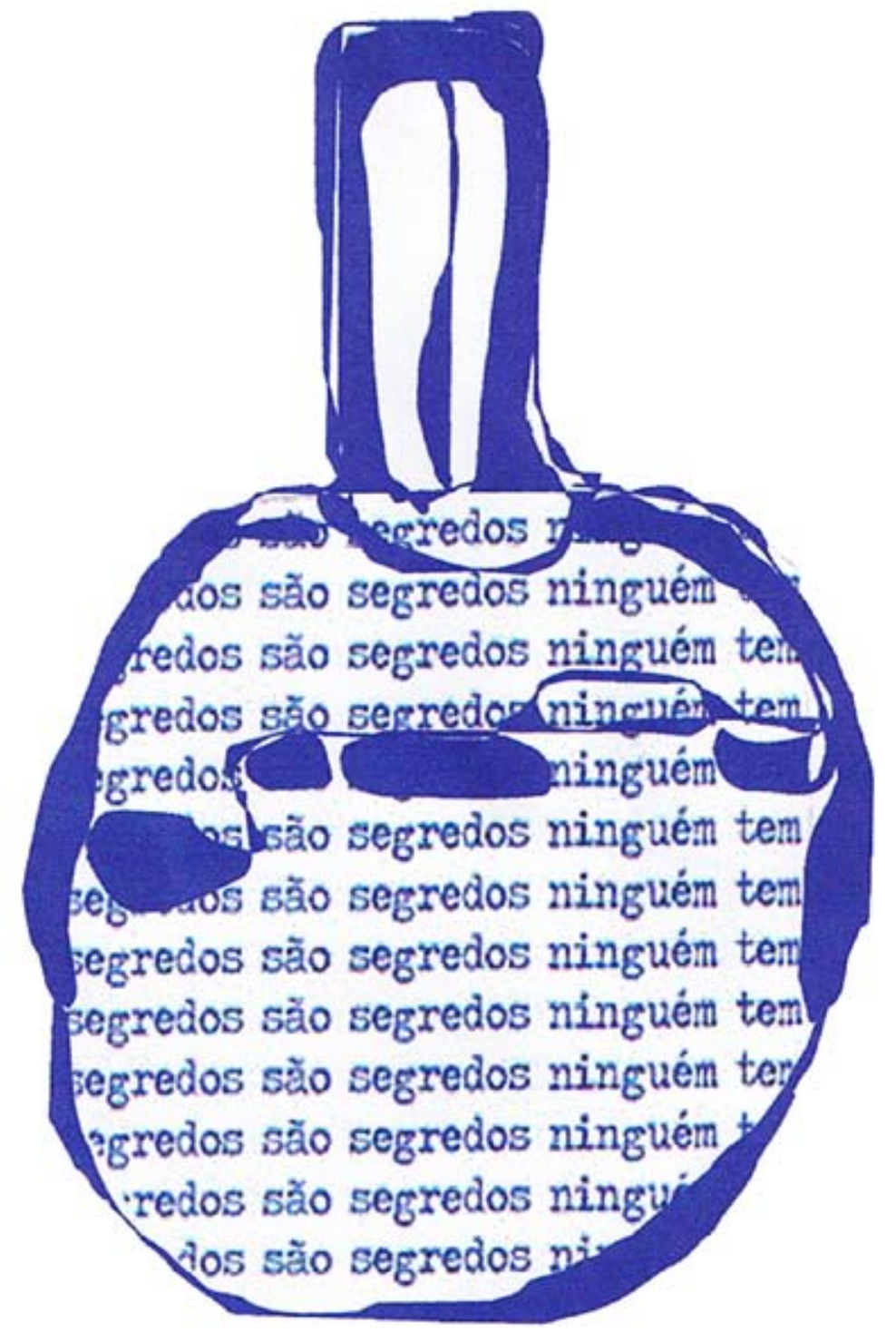




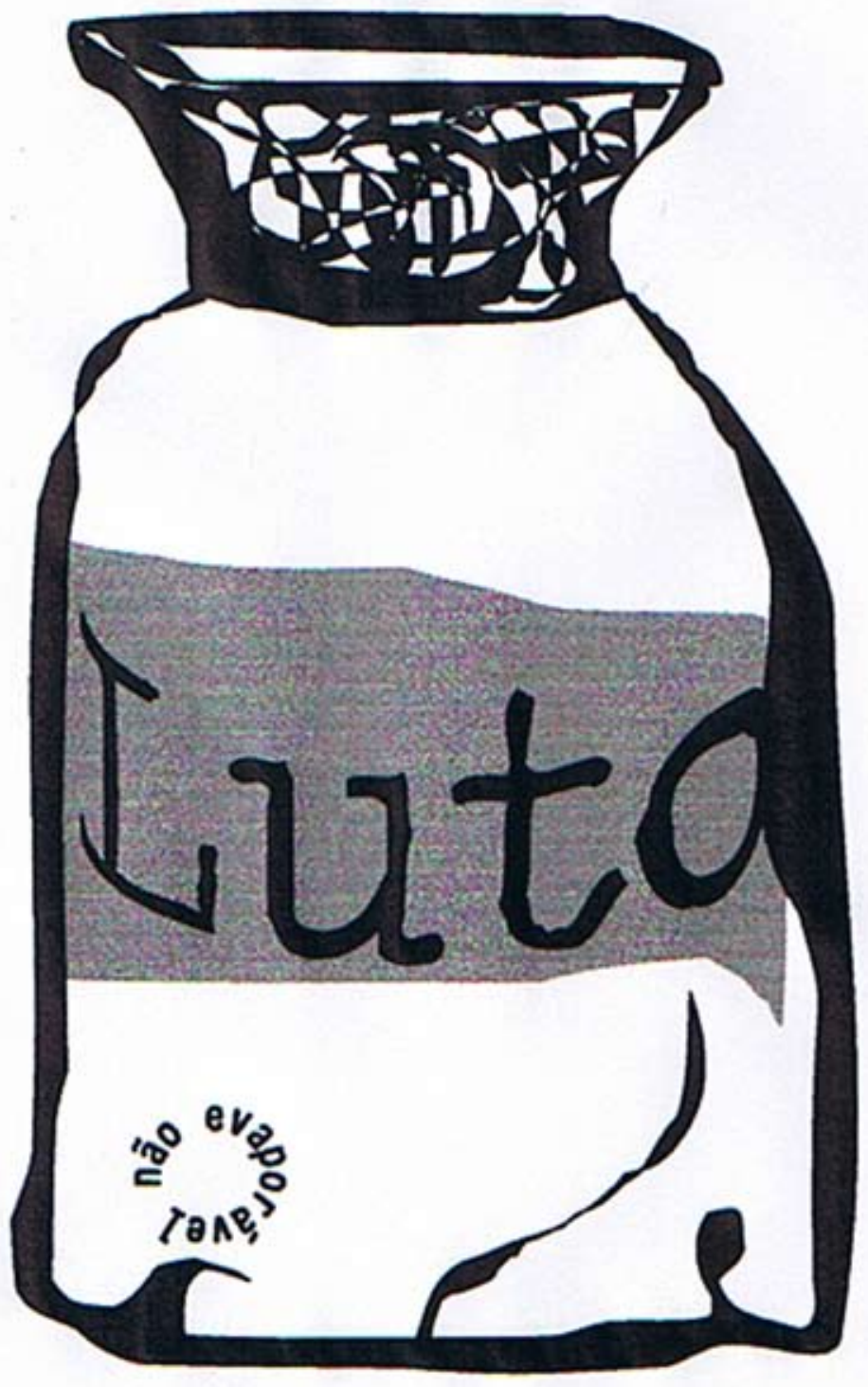




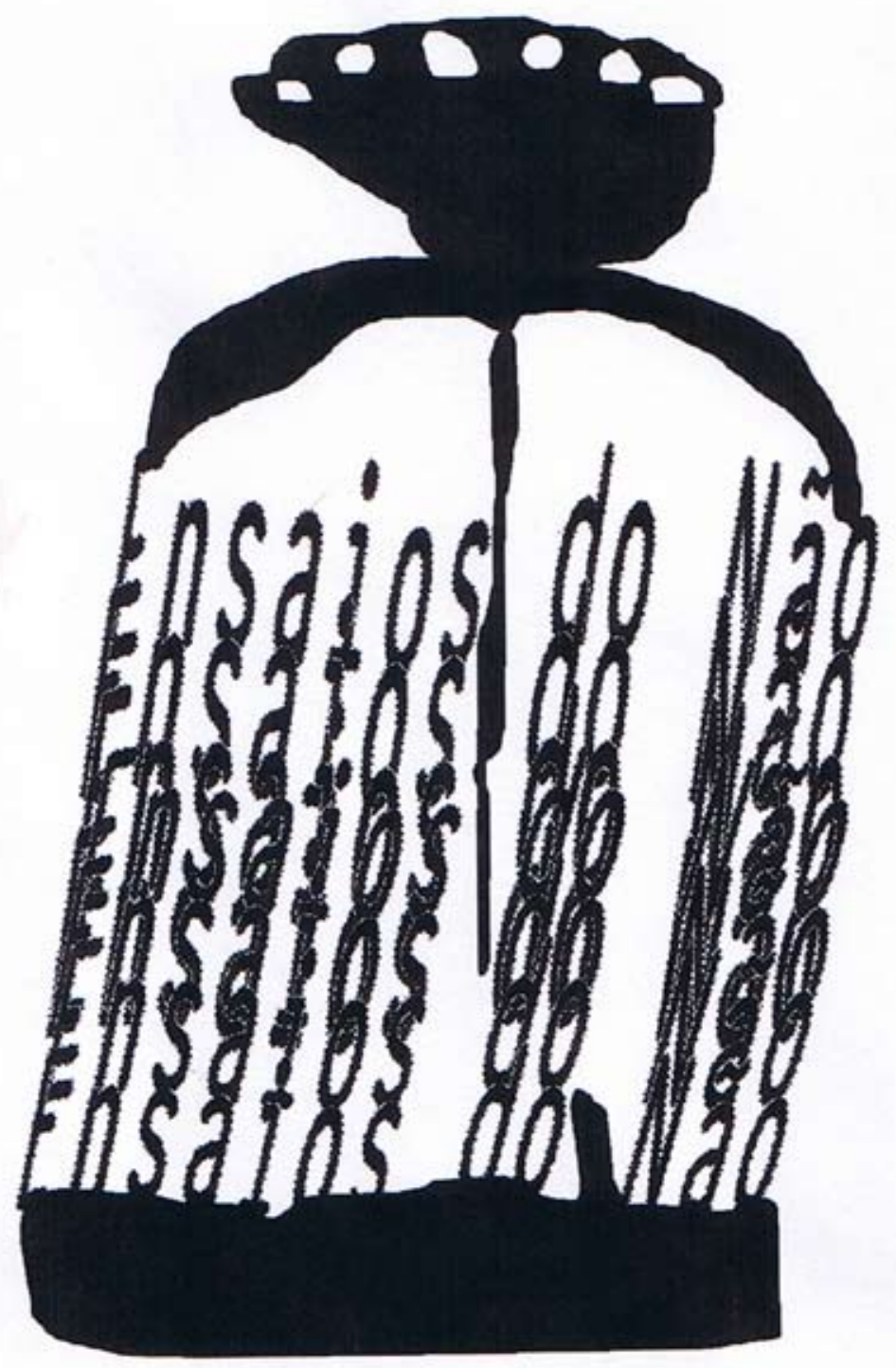




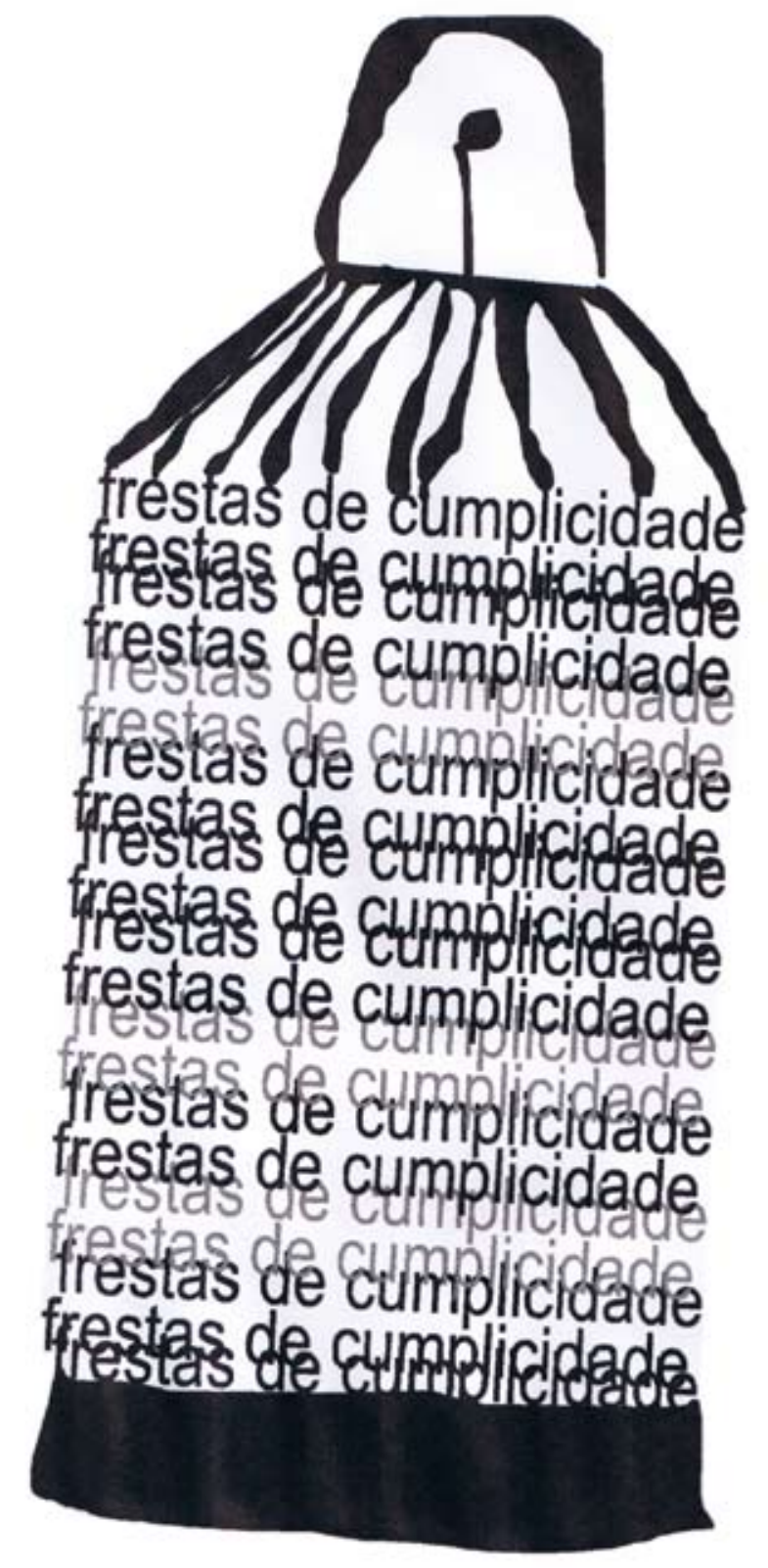




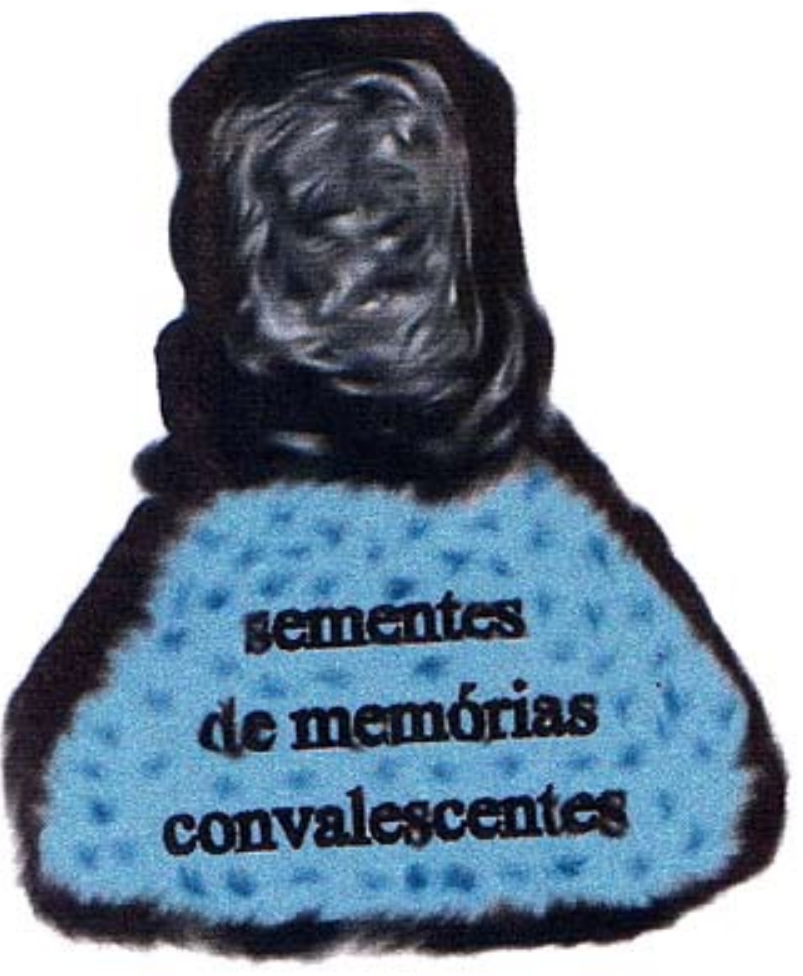




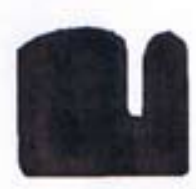

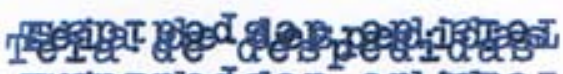

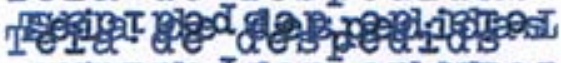

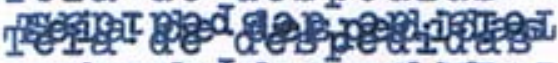
rigen

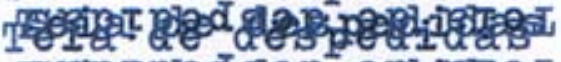
TE

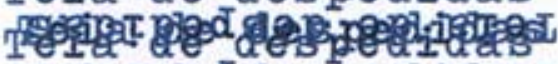

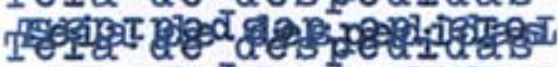

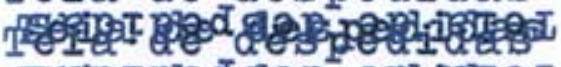

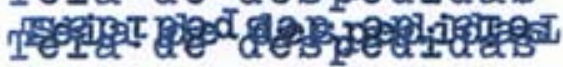




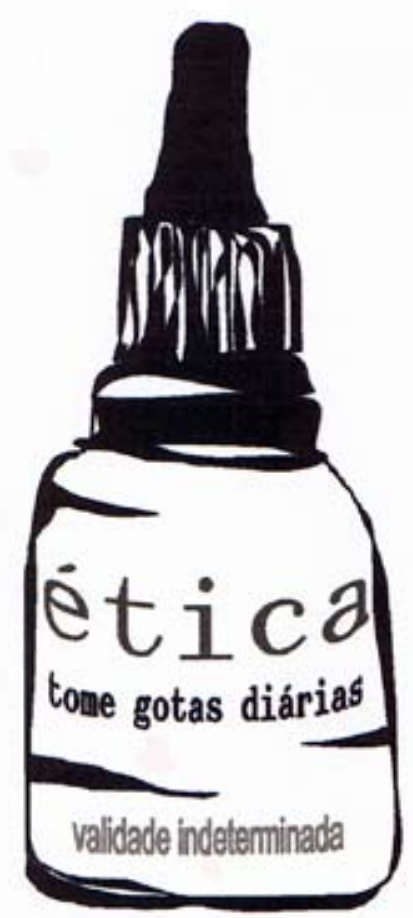




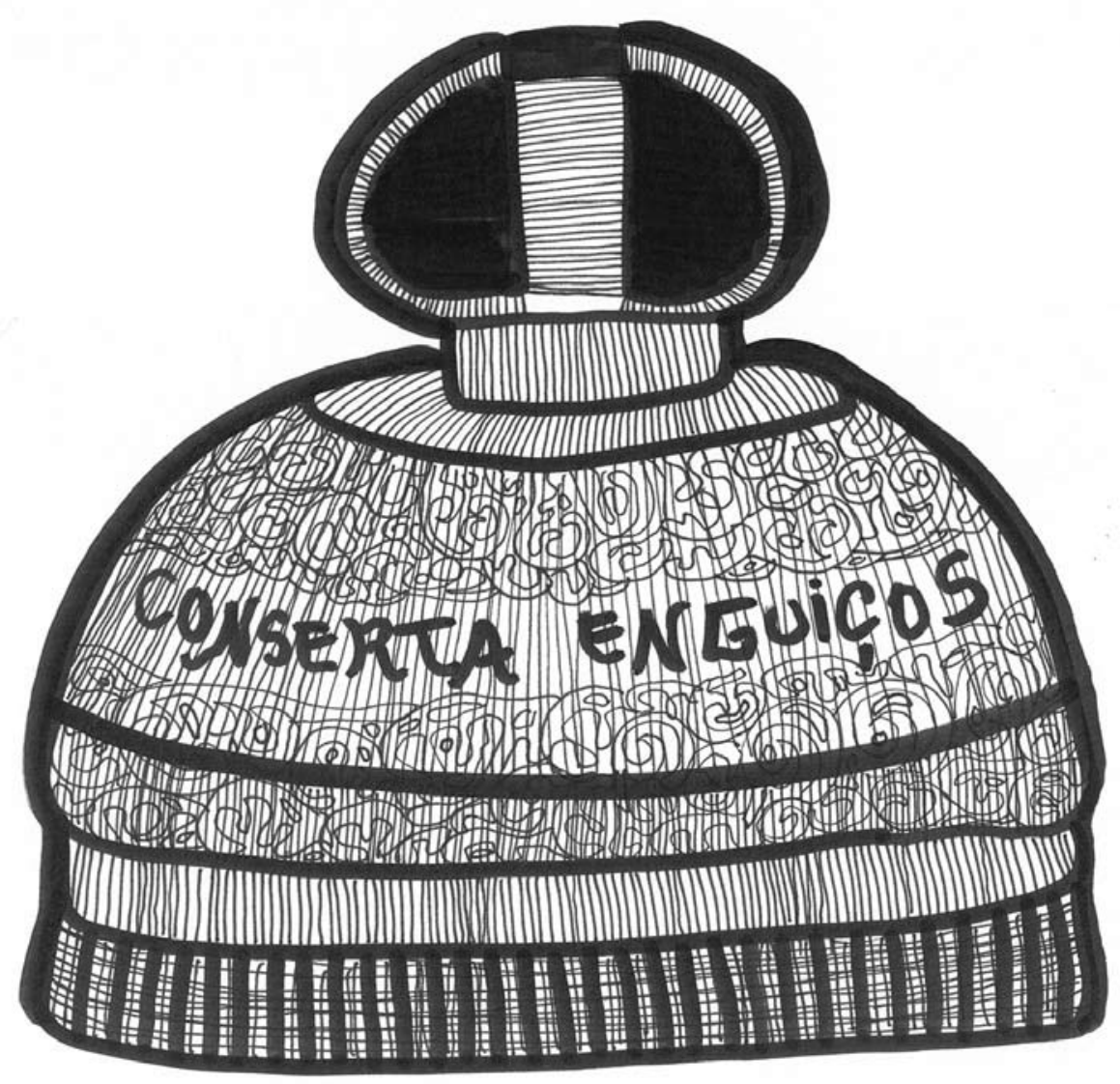




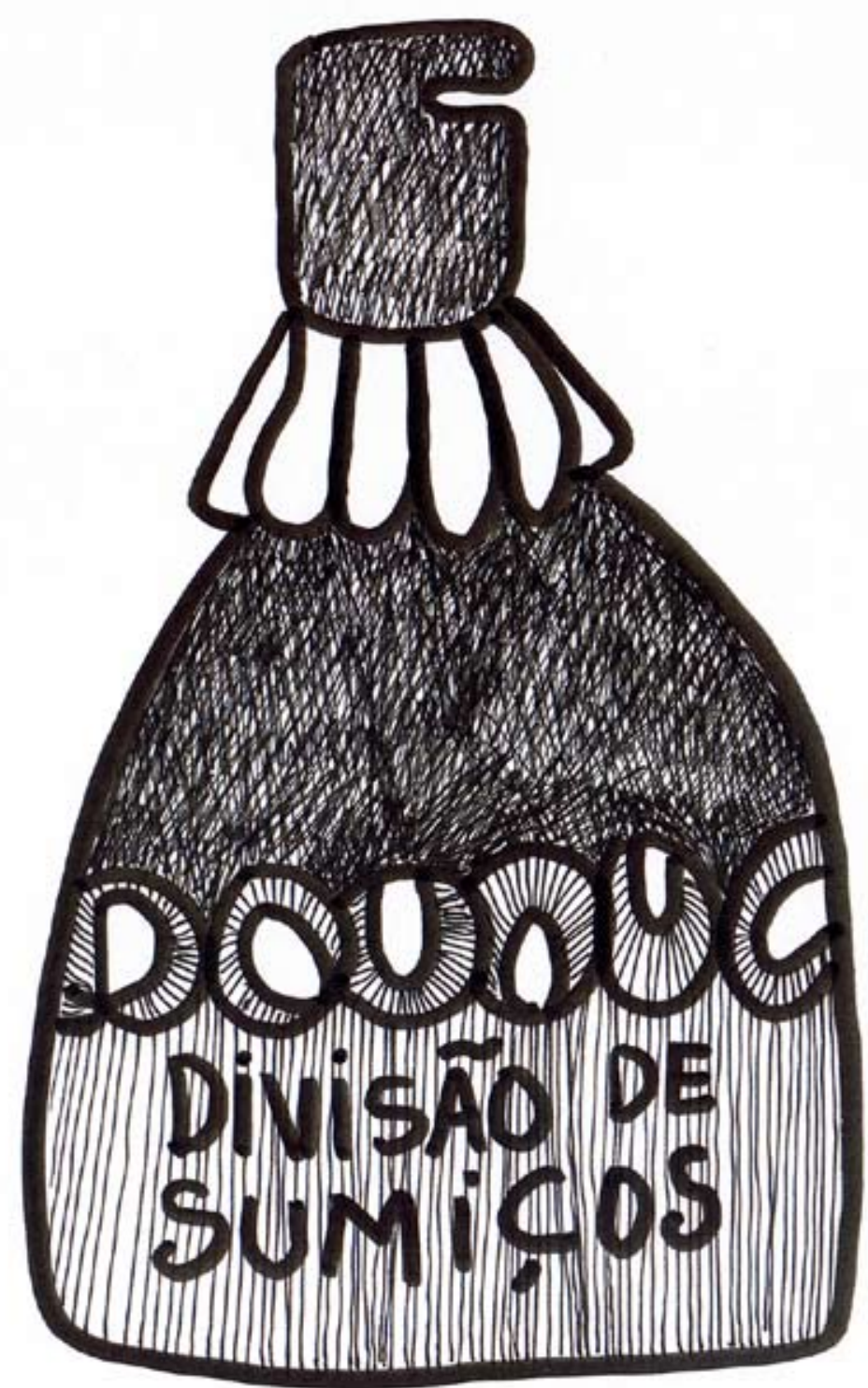




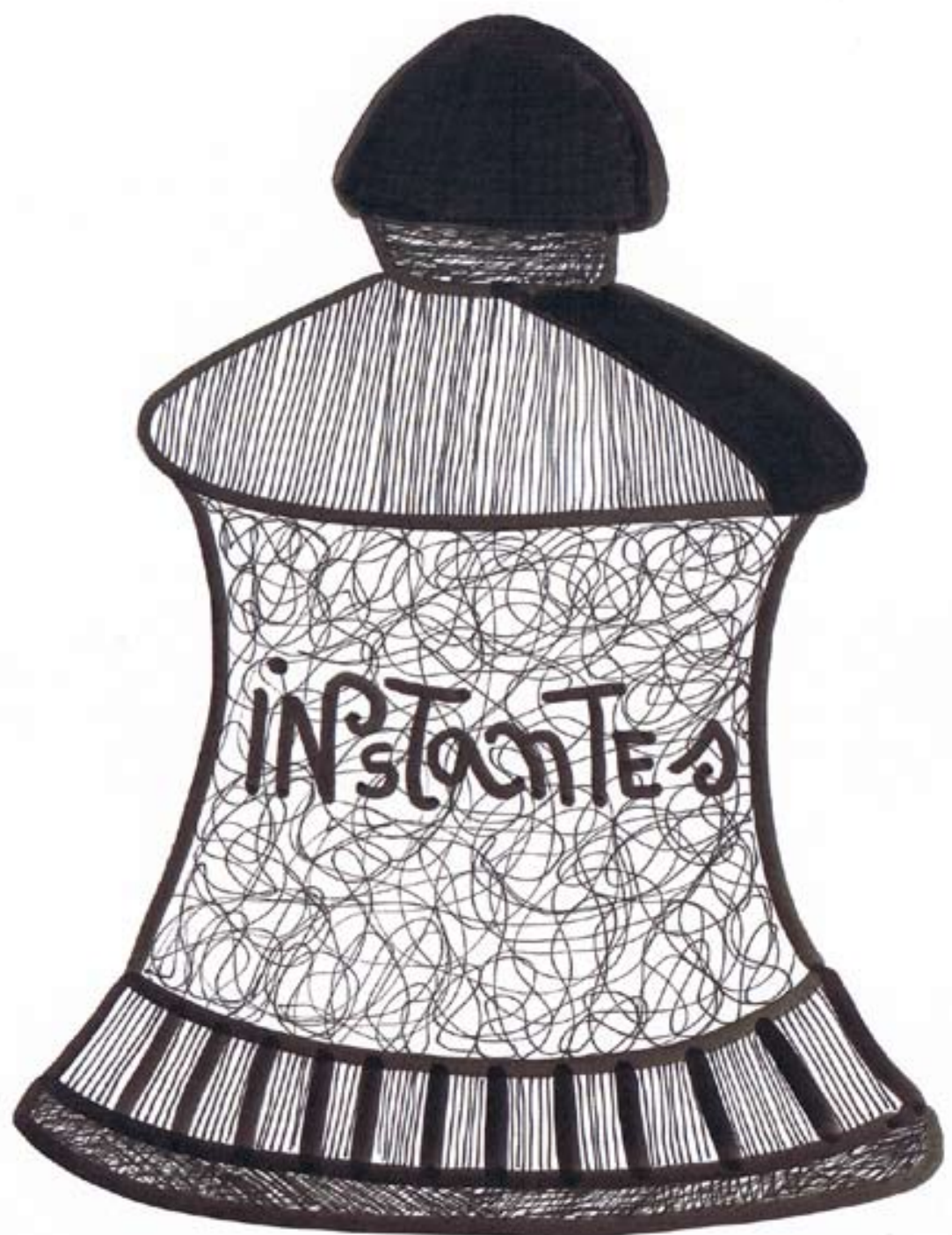




$$
9
$$




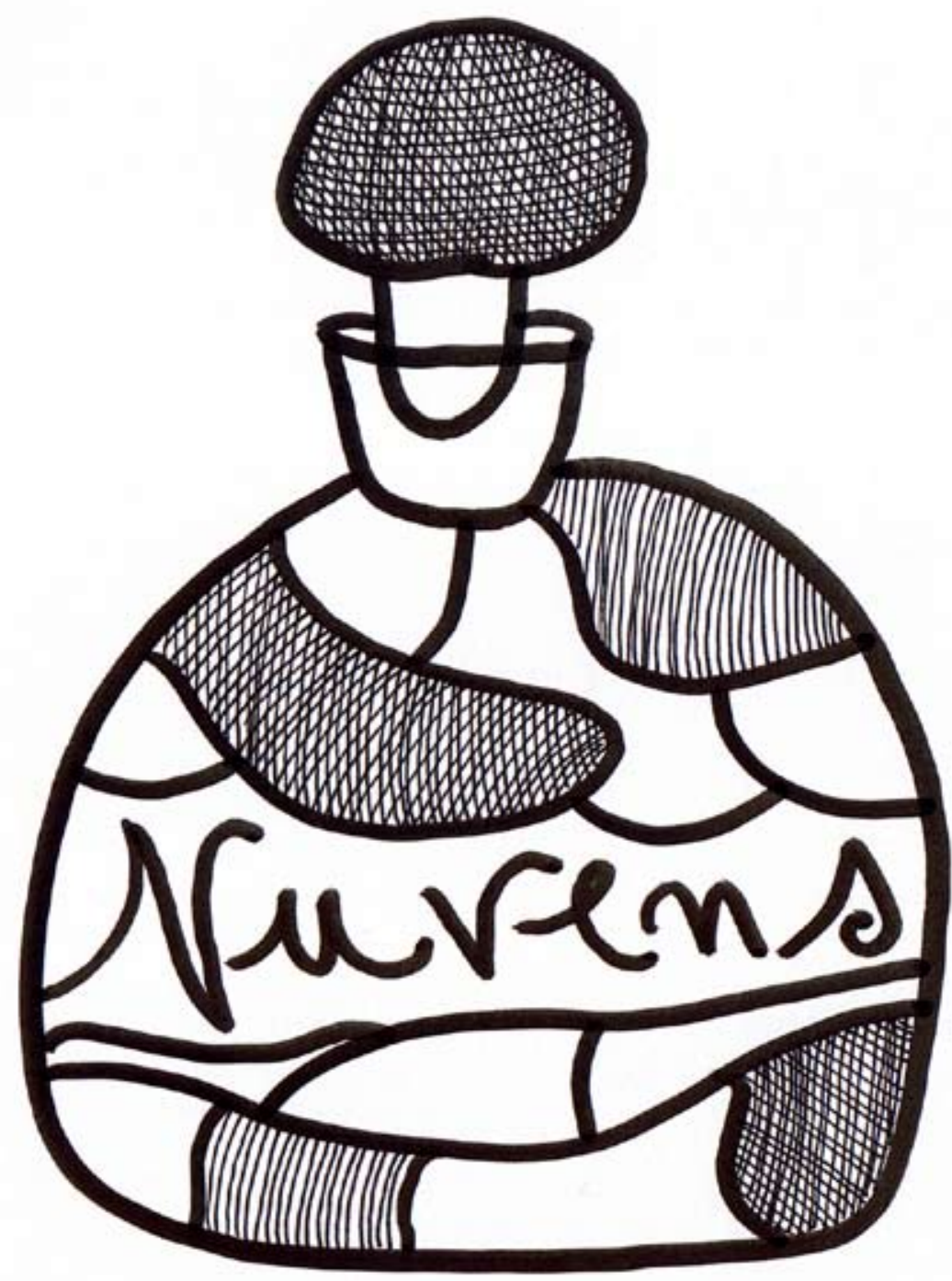




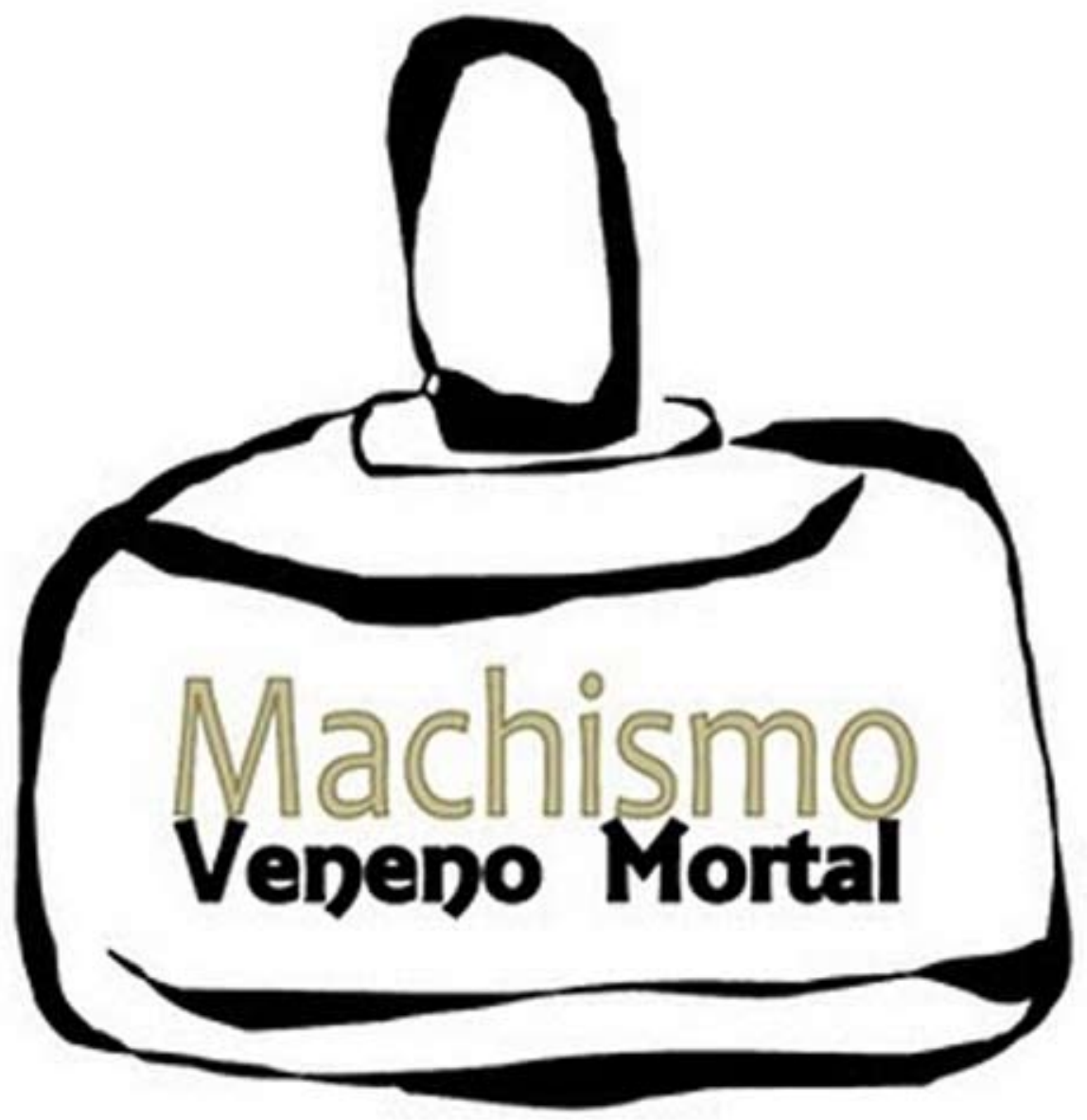




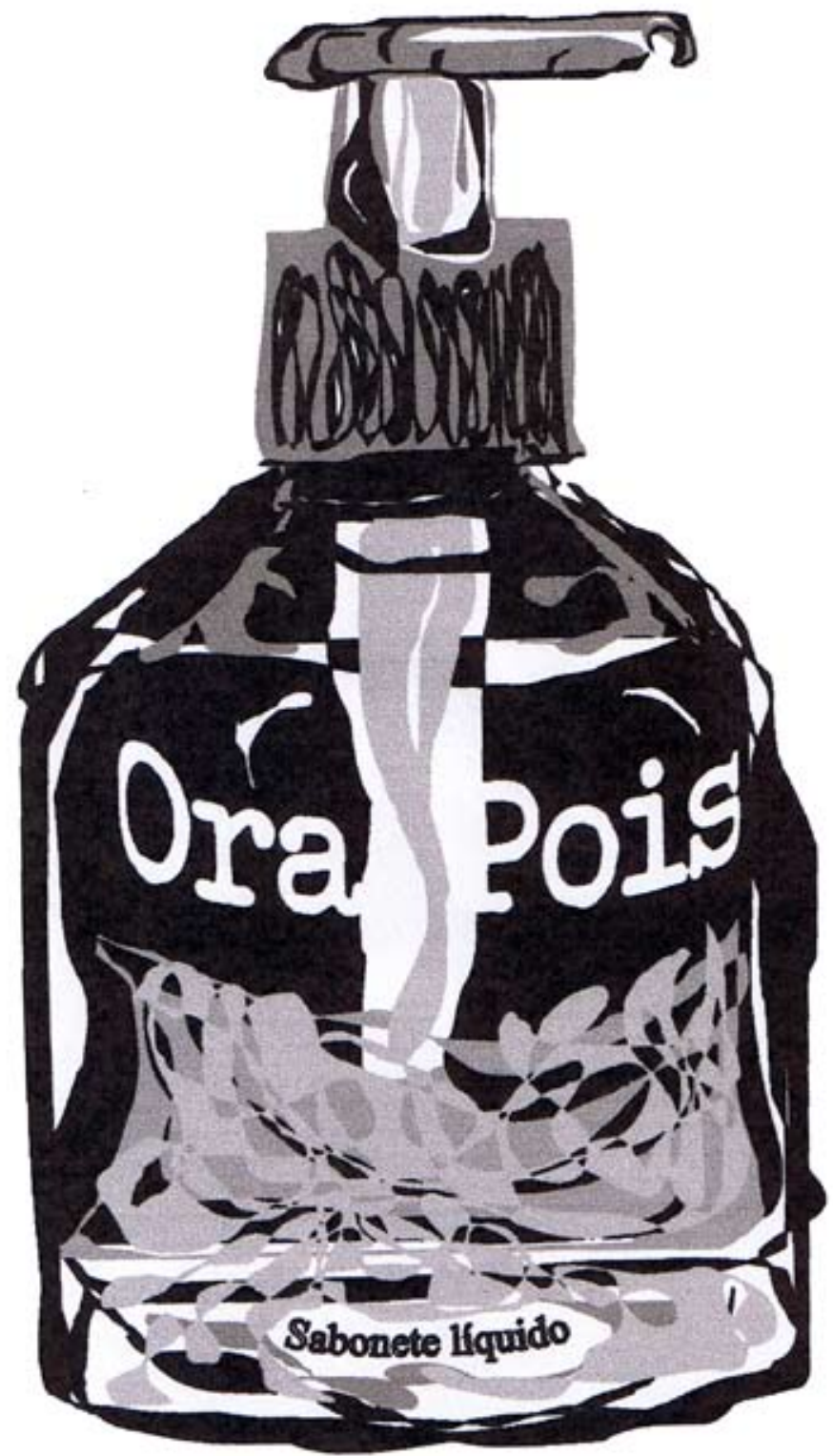





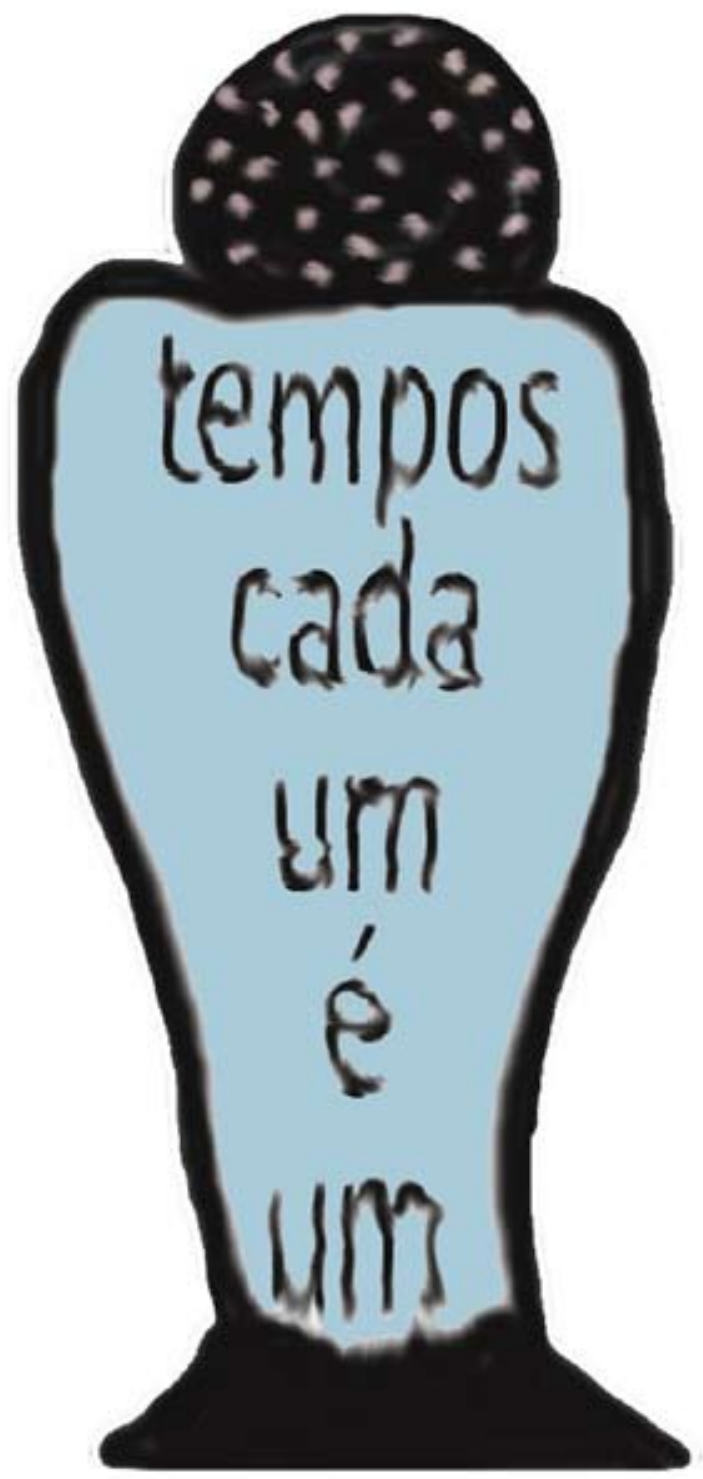




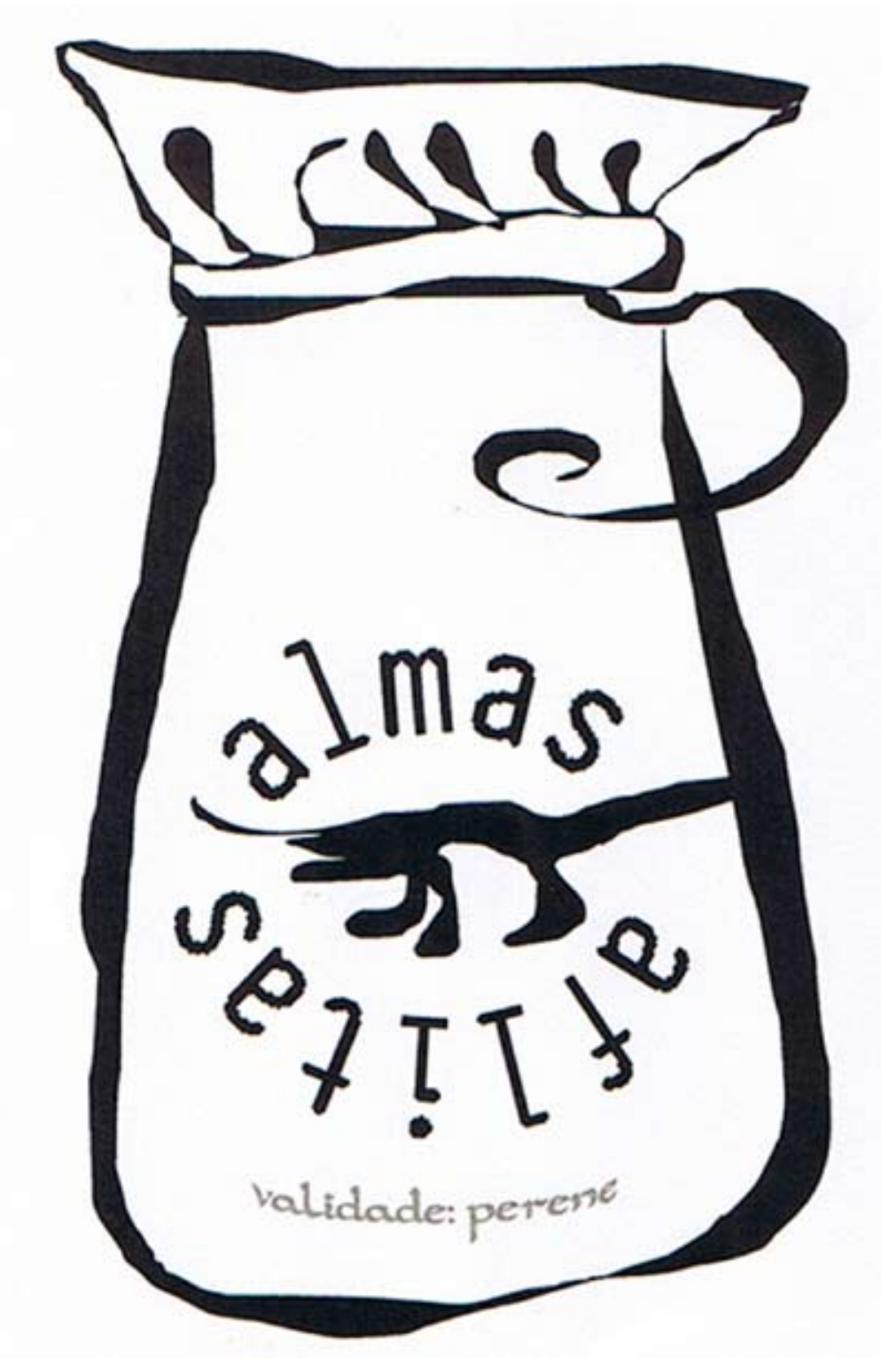




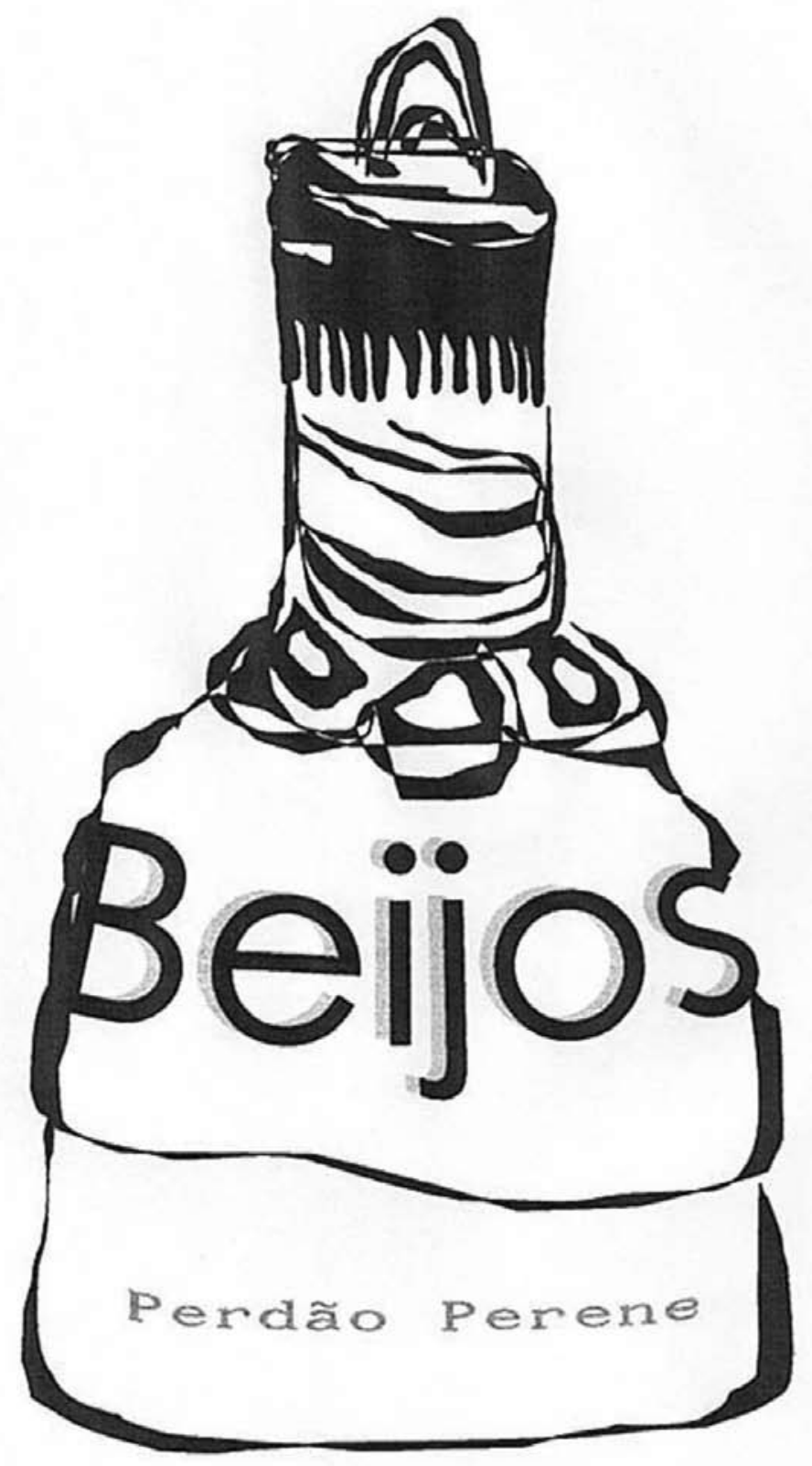



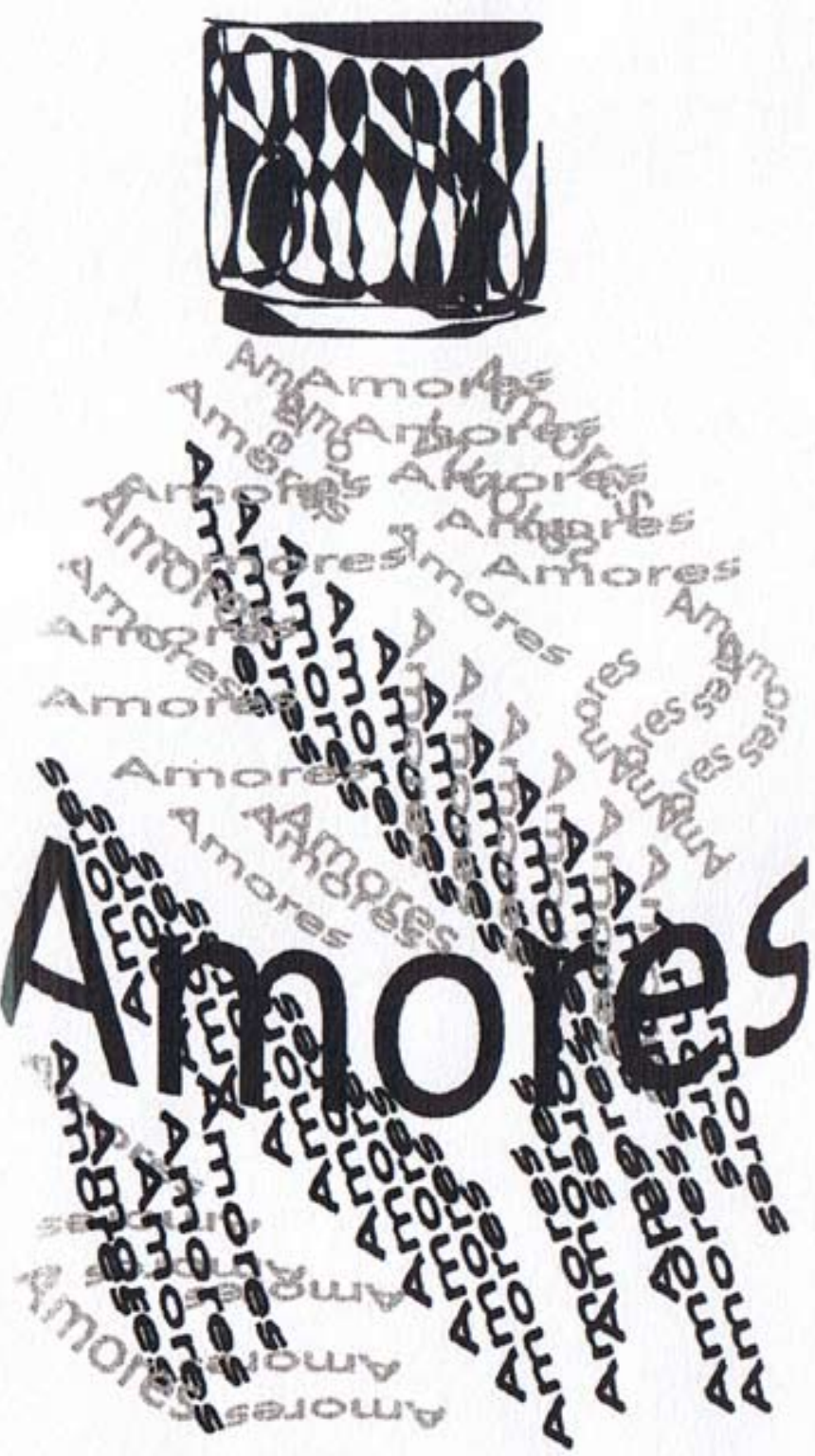


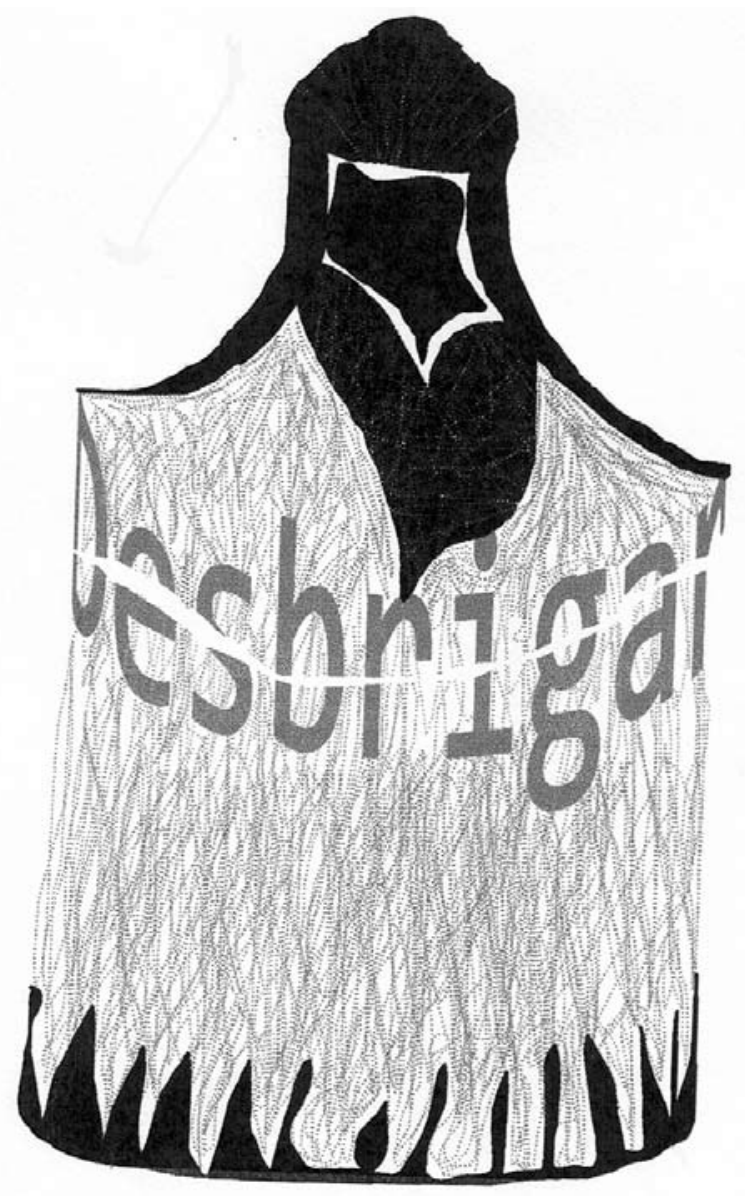




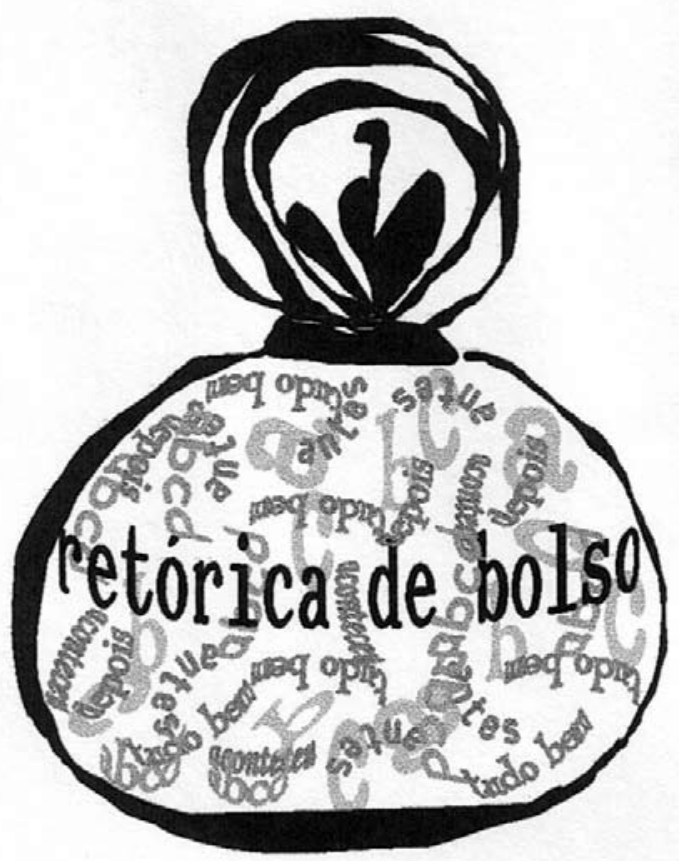




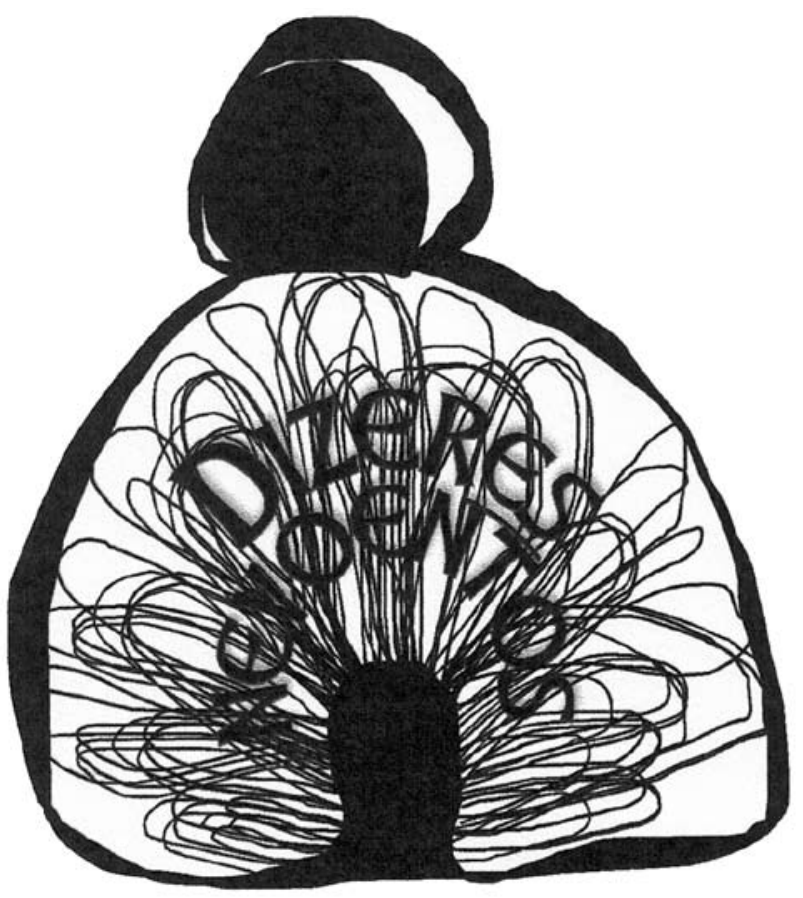




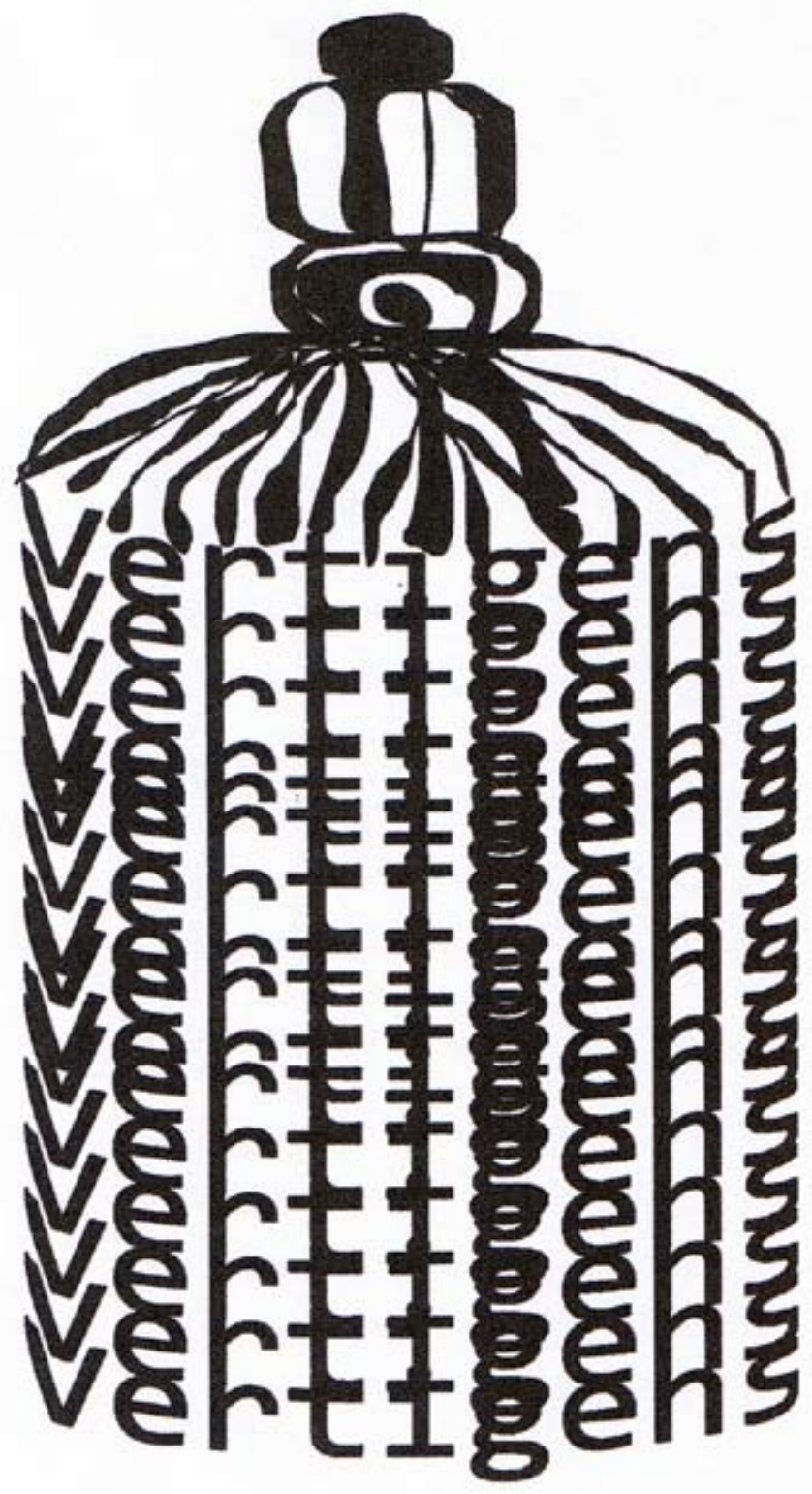




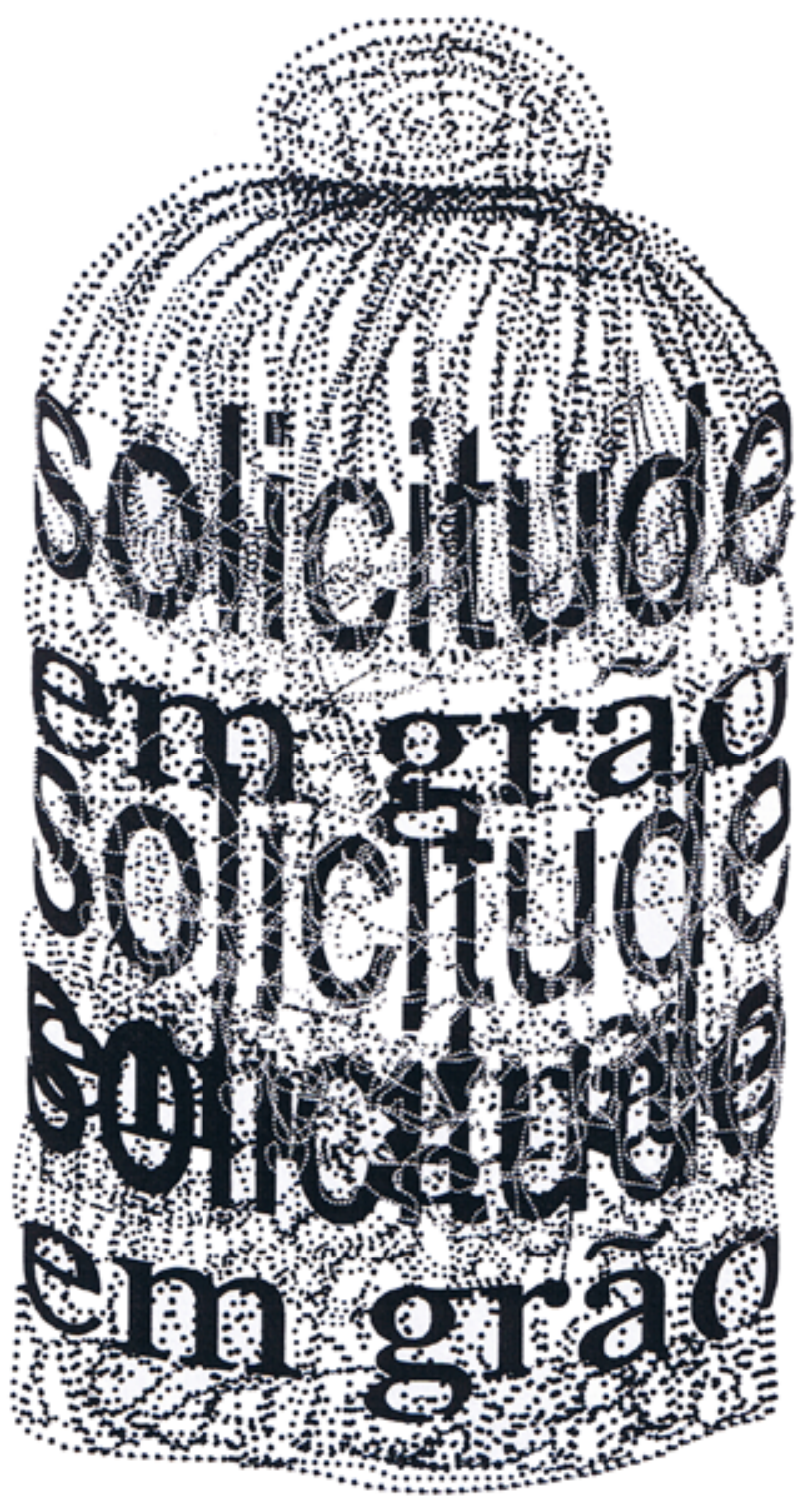




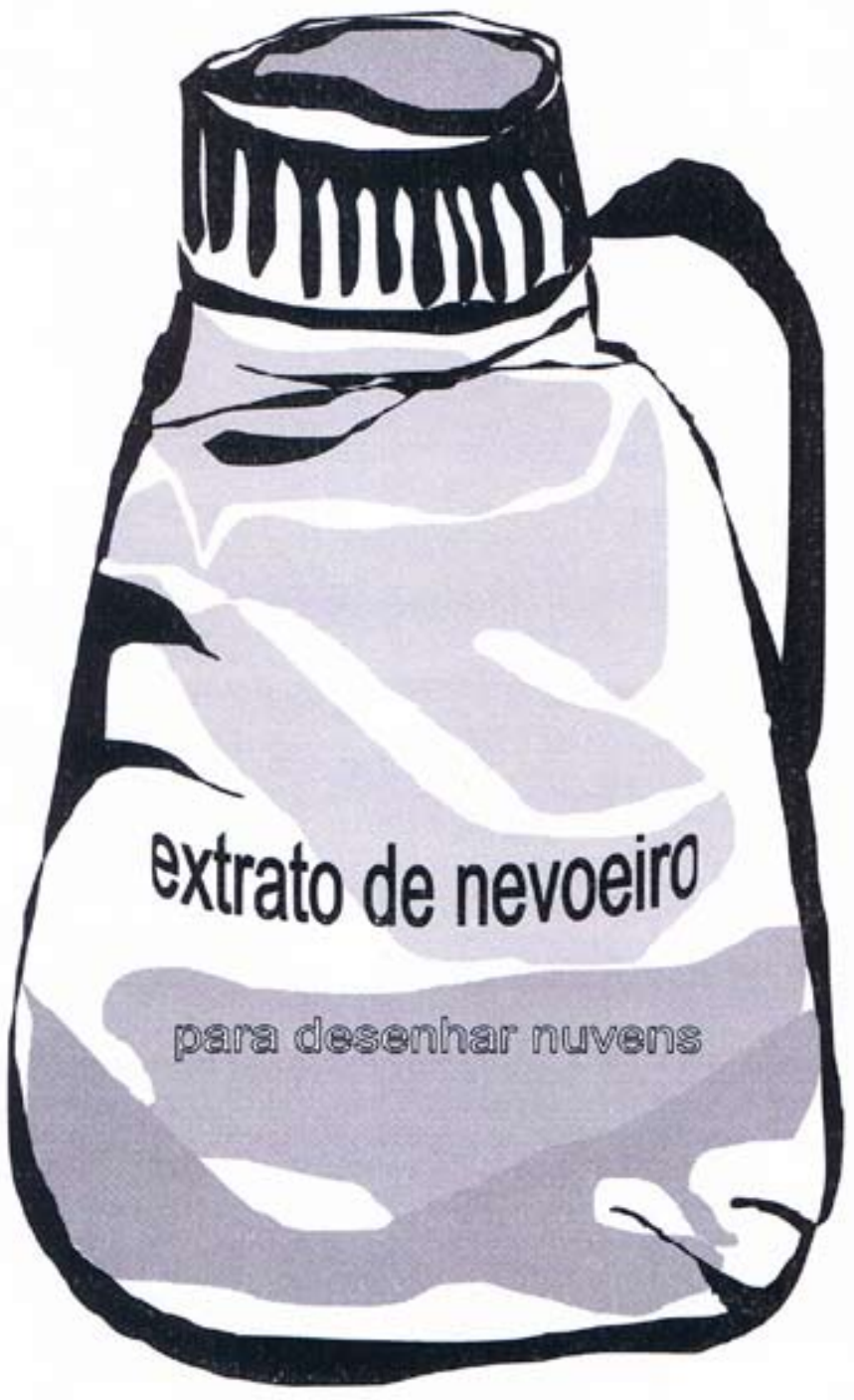




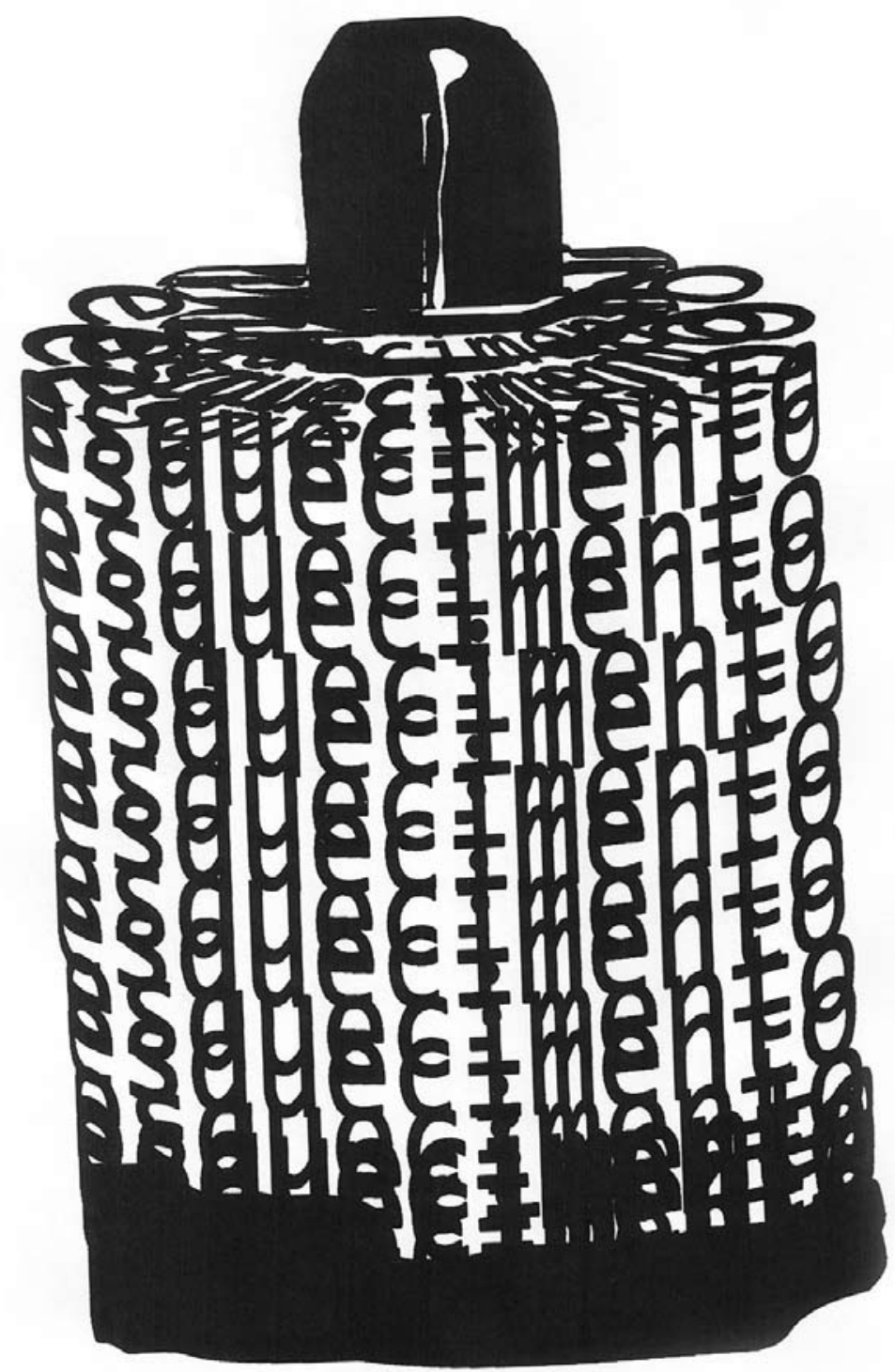




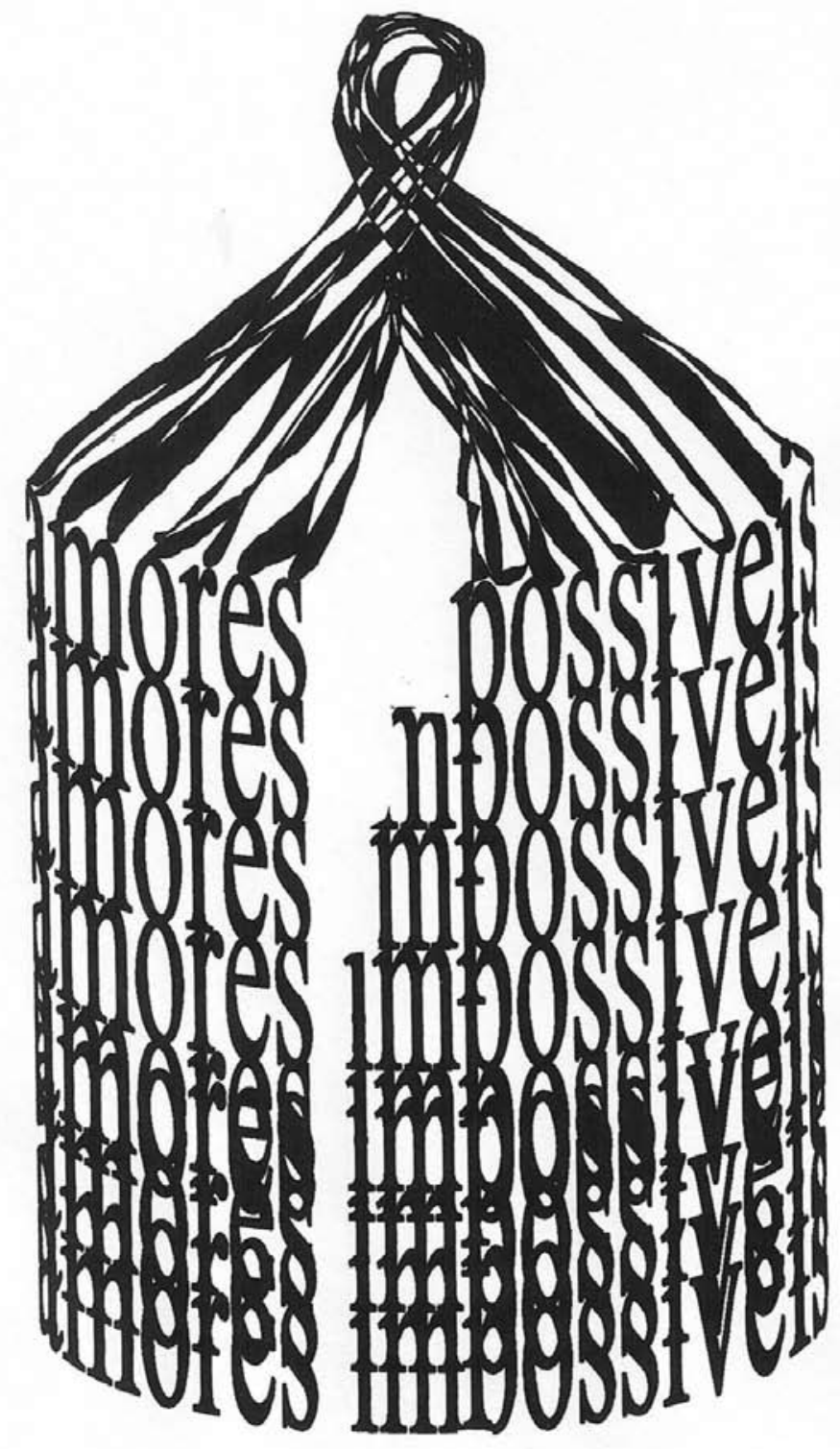




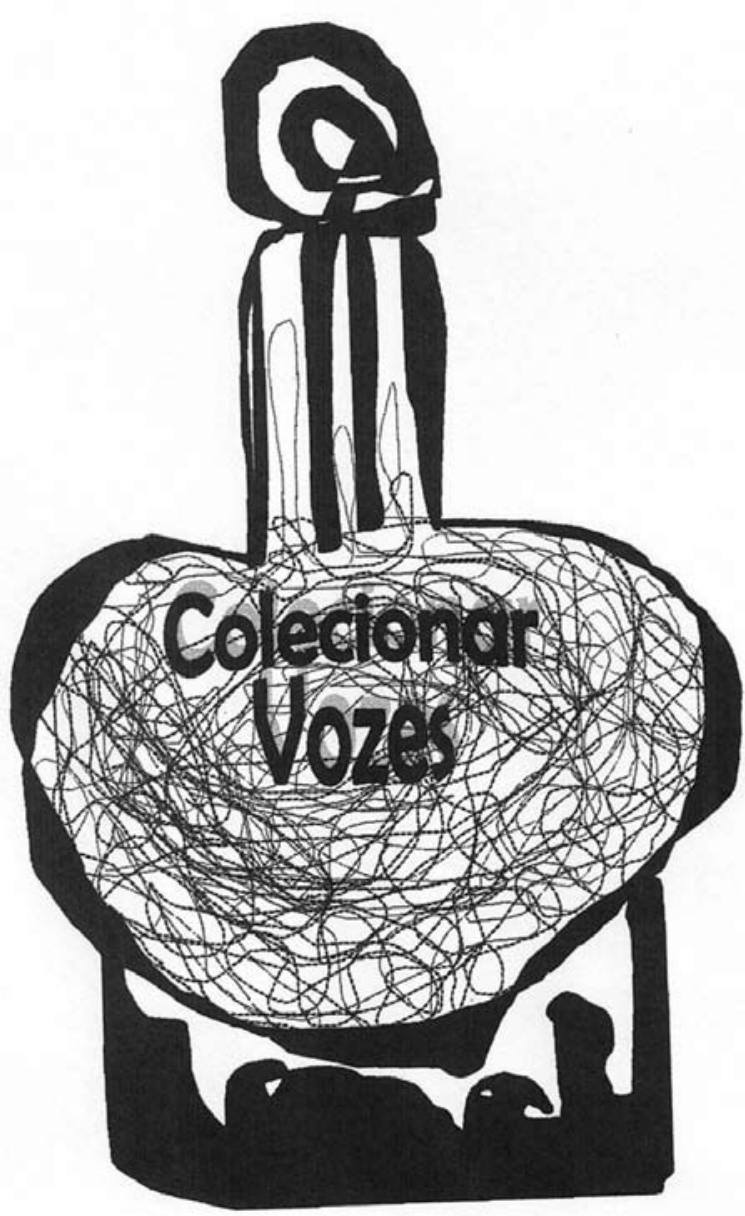




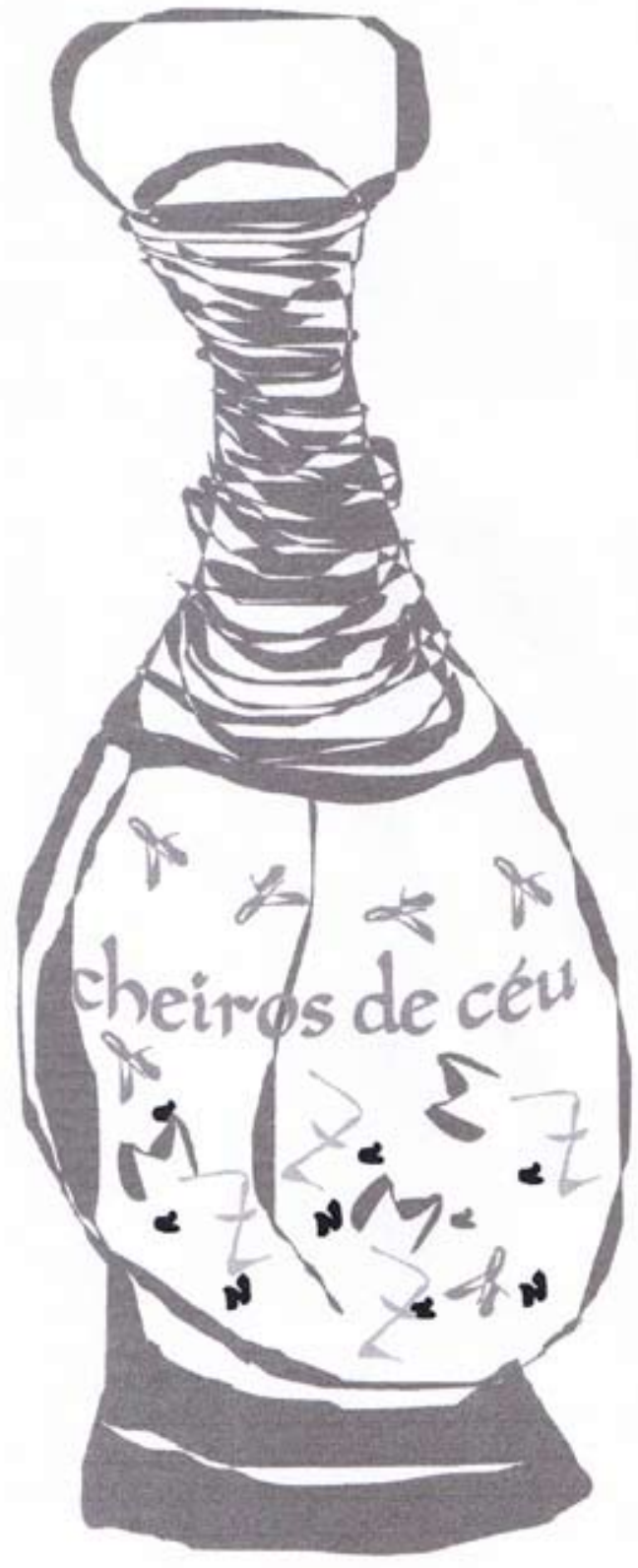




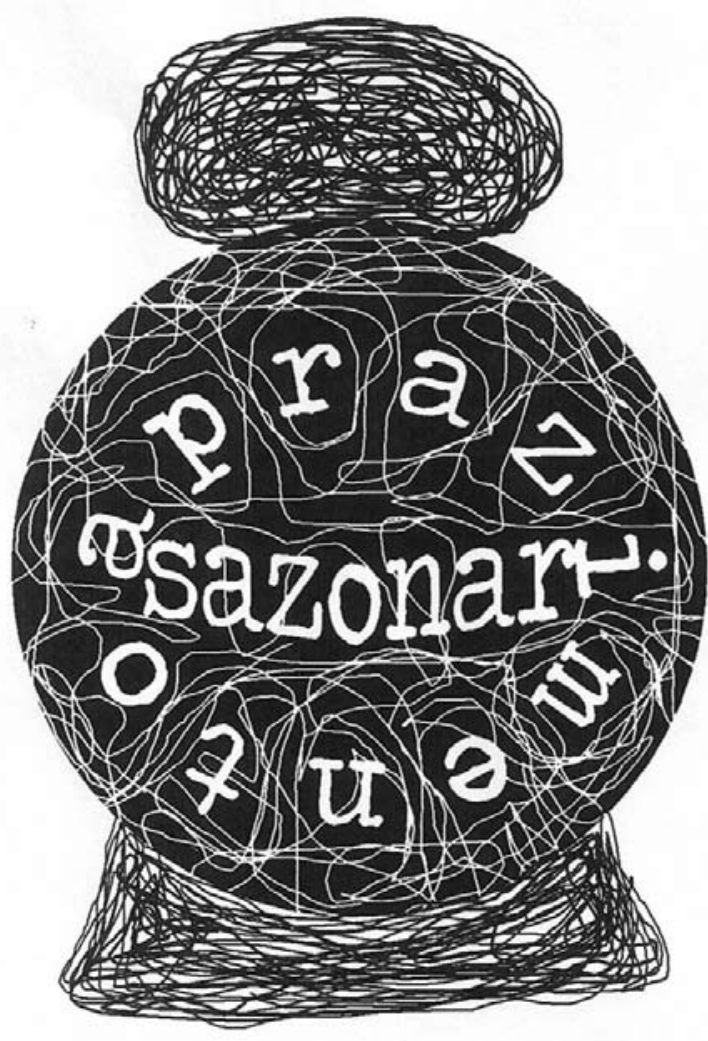




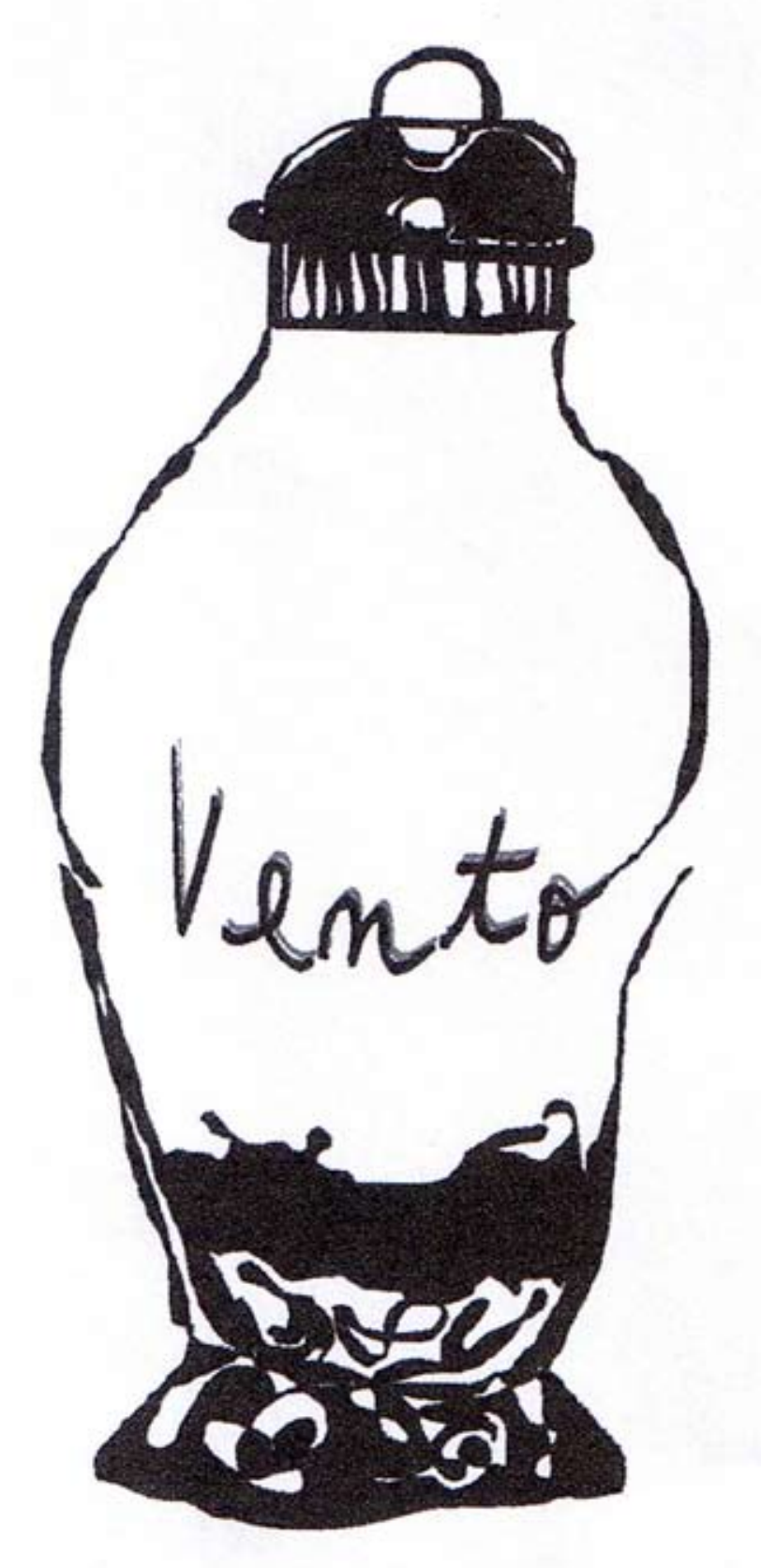




\section{Poemas Visuais em formato postal}

De 2009 a 2012, enviei 42 poemas visuais editados em formato de cartão postal. Postais como suporte de um projeto artístico específico. Tendo como premissa a partilha de realidades e pensamentos poéticos. O poema visual como obra de arte integrante de uma renovação contínua do meio cultural em que existe.

Usei os correios para o envio dos postais com poemas visuais a uma lista de poetas, historiadores, artistas visuais, jornalistas, professores, instituições e revistas culturais, no Brasil e no exterior. Criando assim uma rede de cumplicidade, onde cada participante tomou posse do poema visual recebido. 


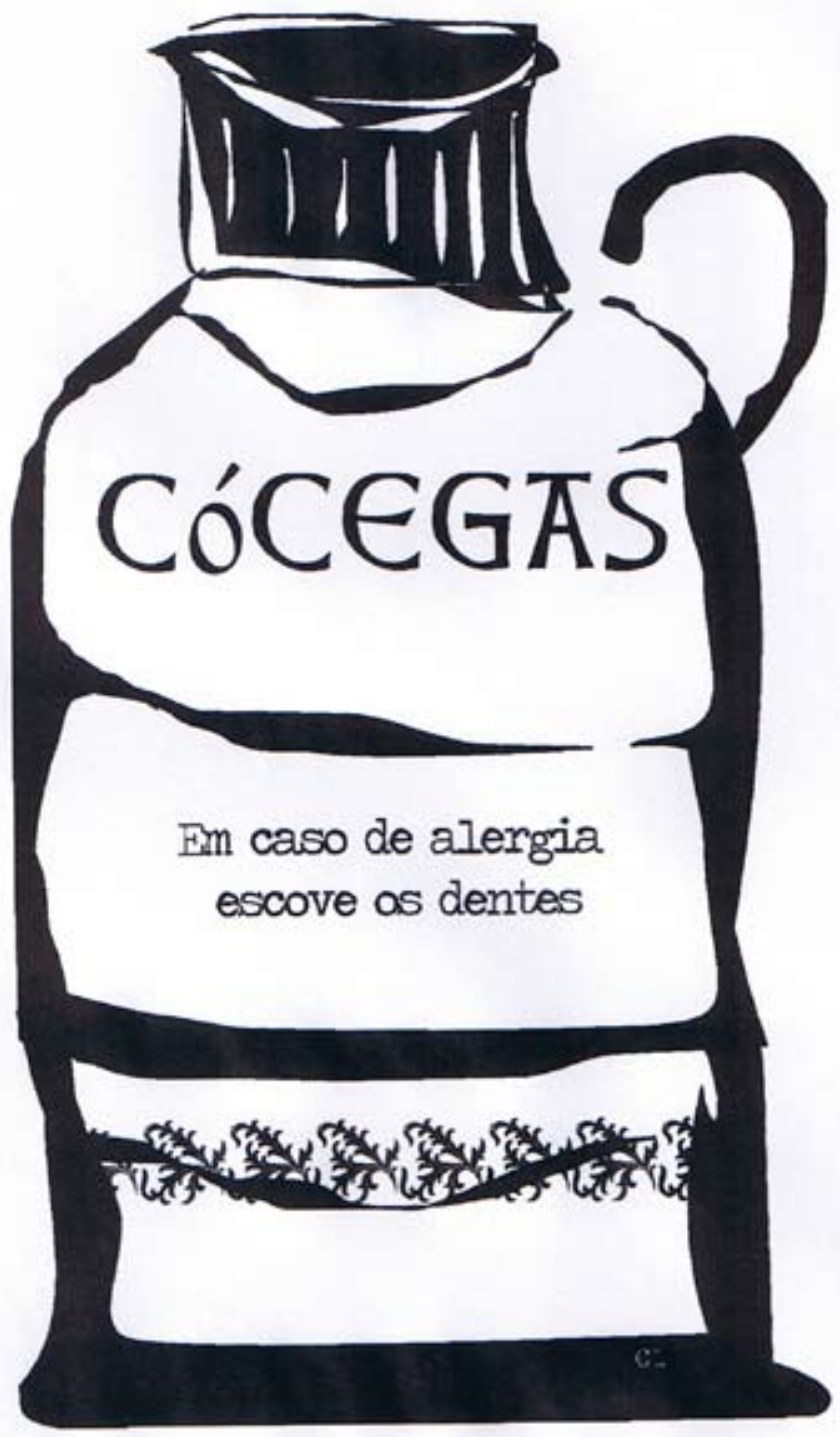




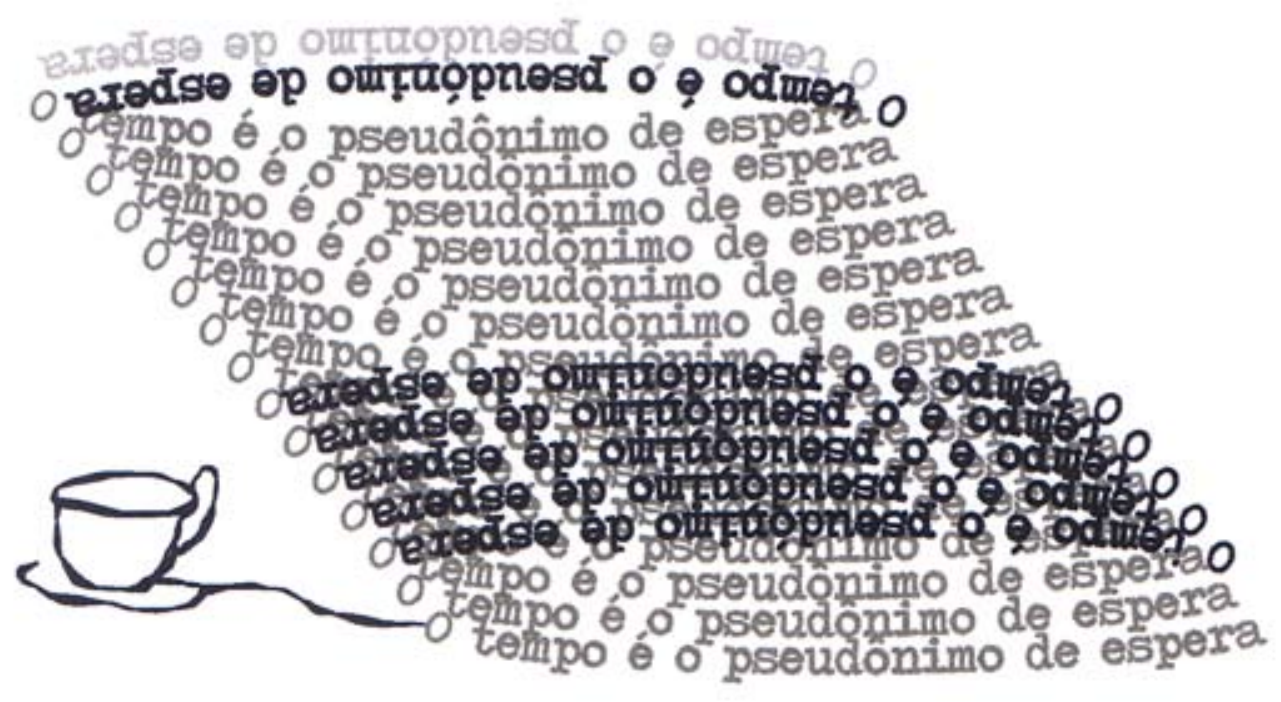




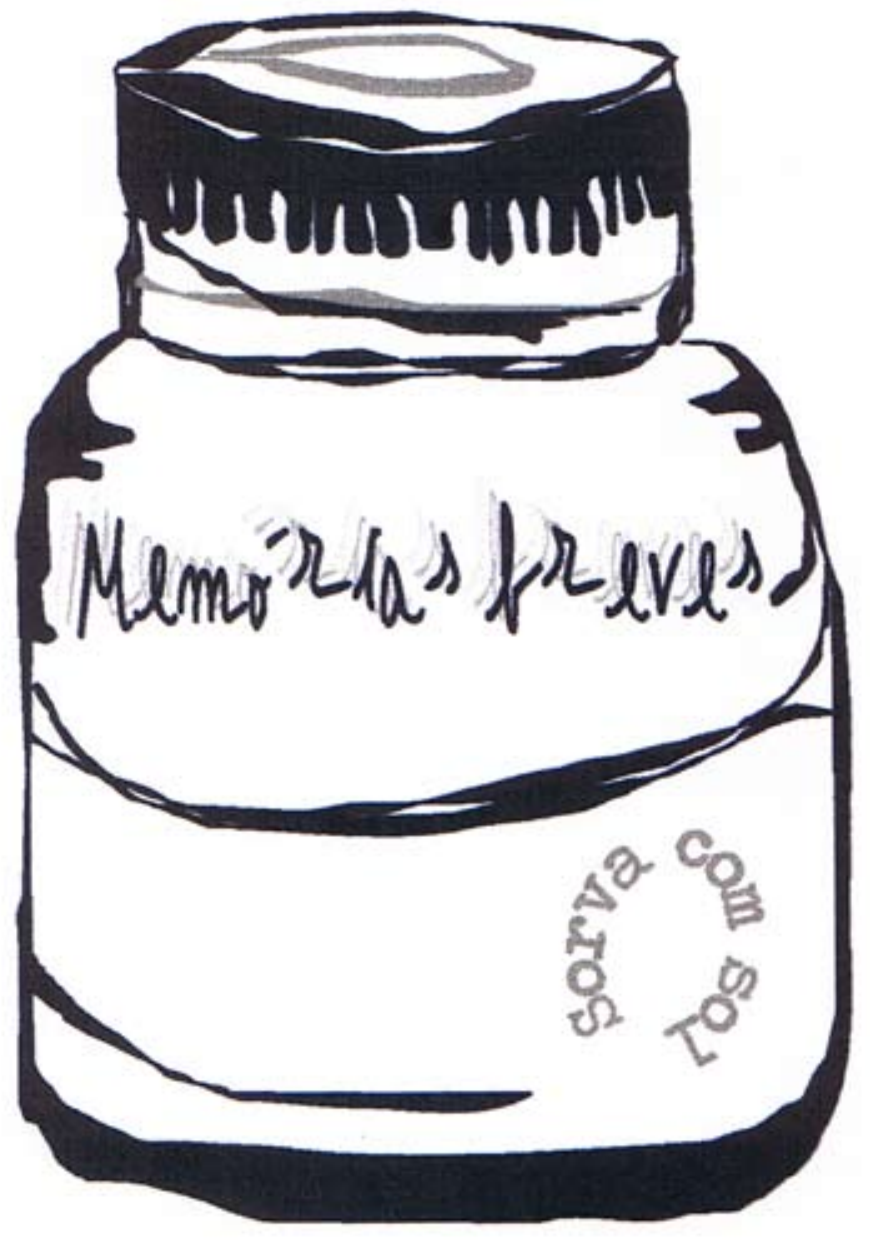




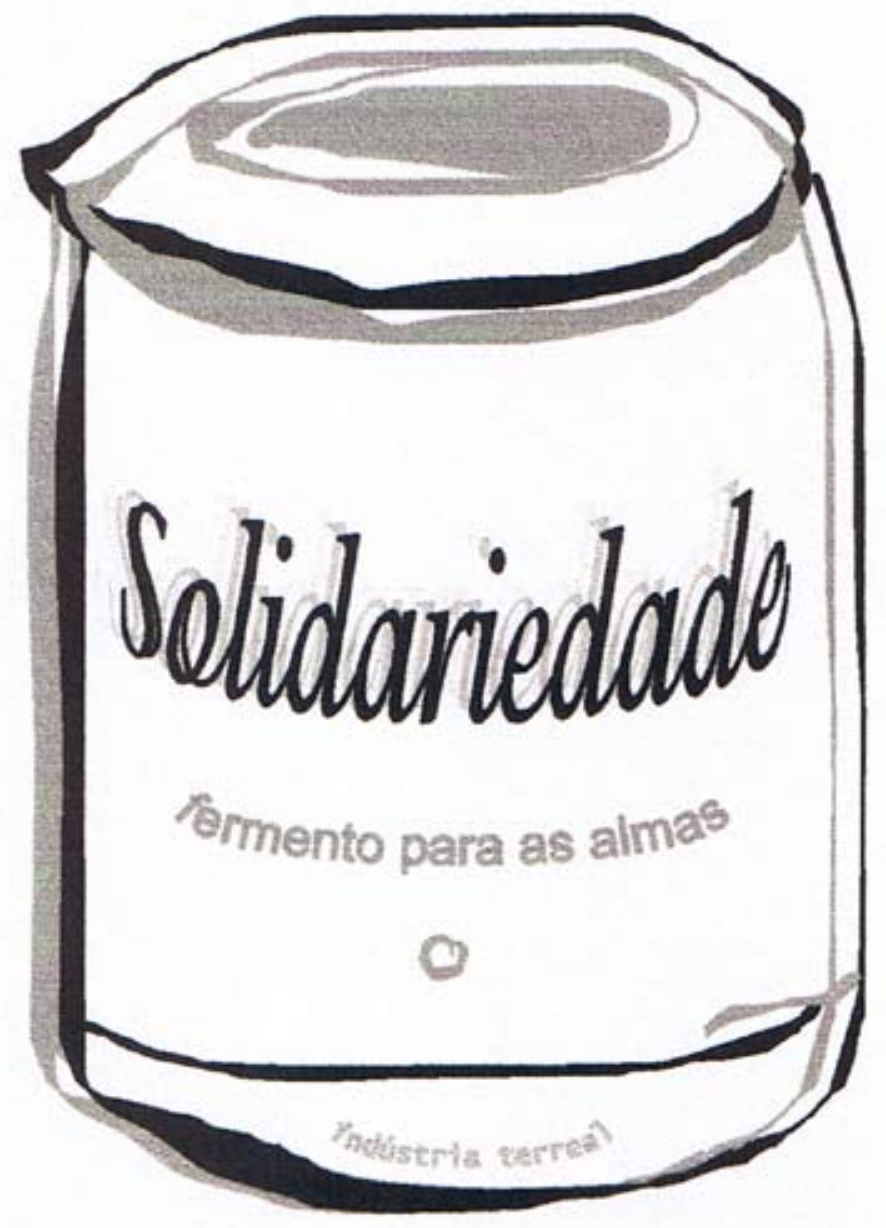




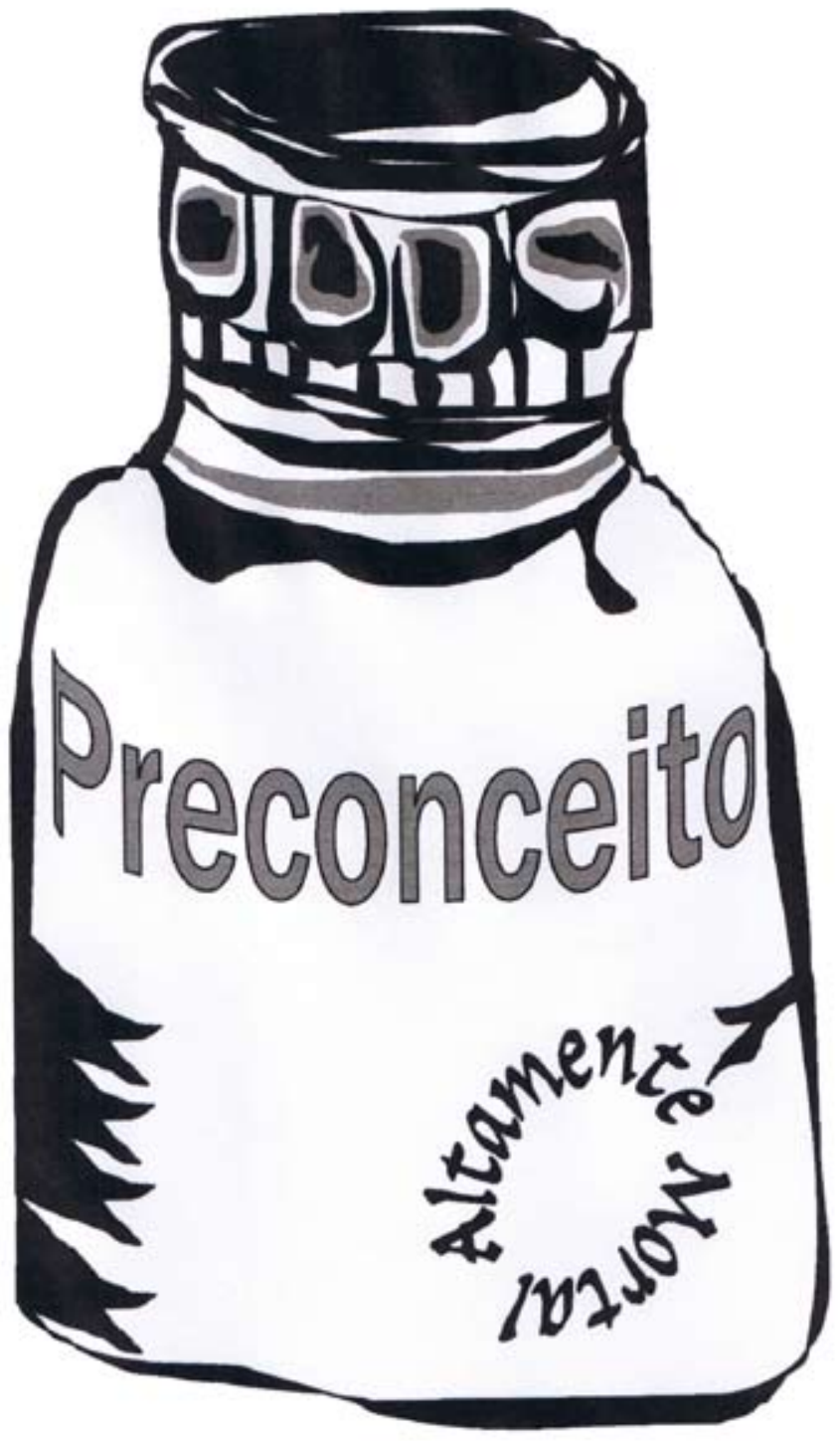




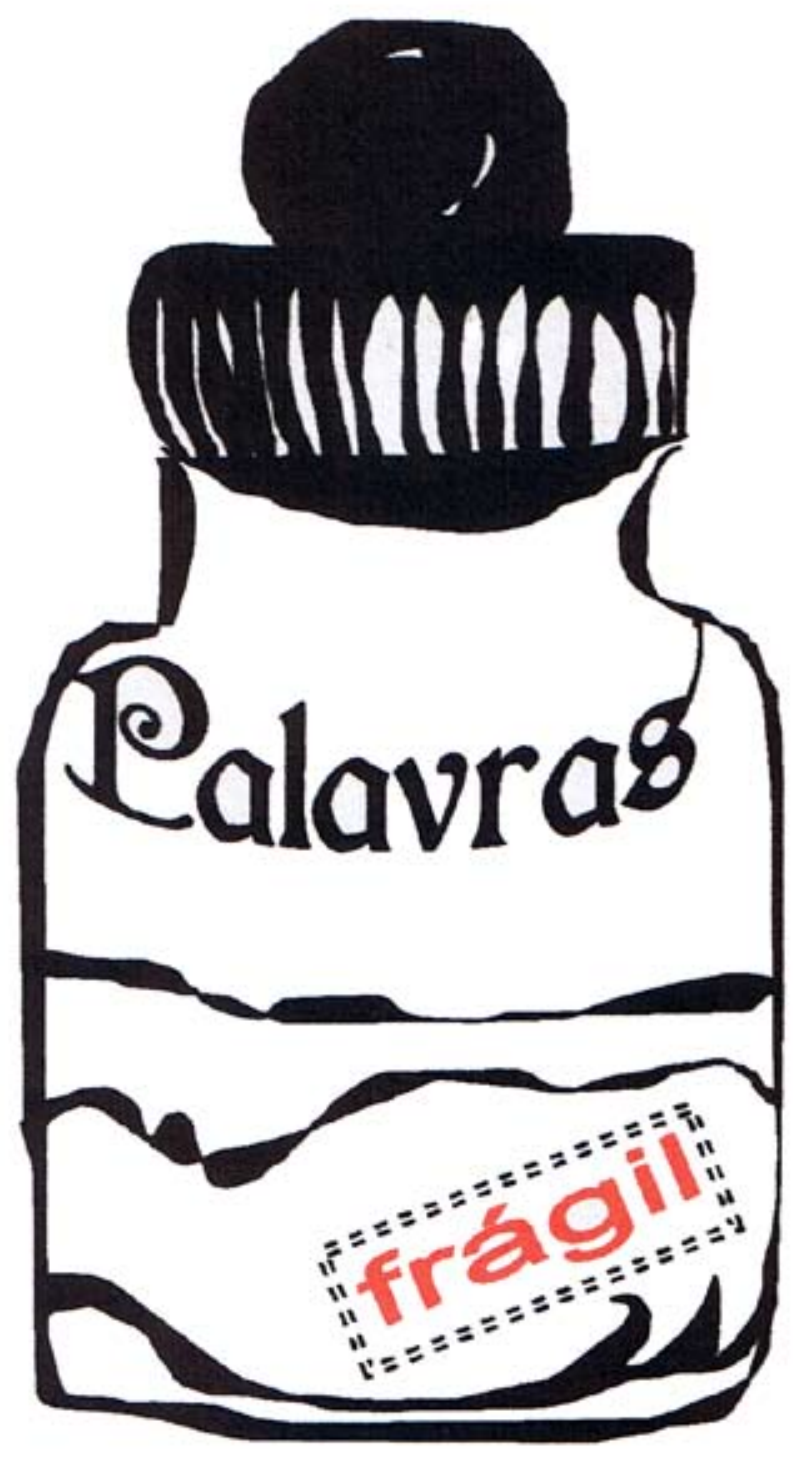




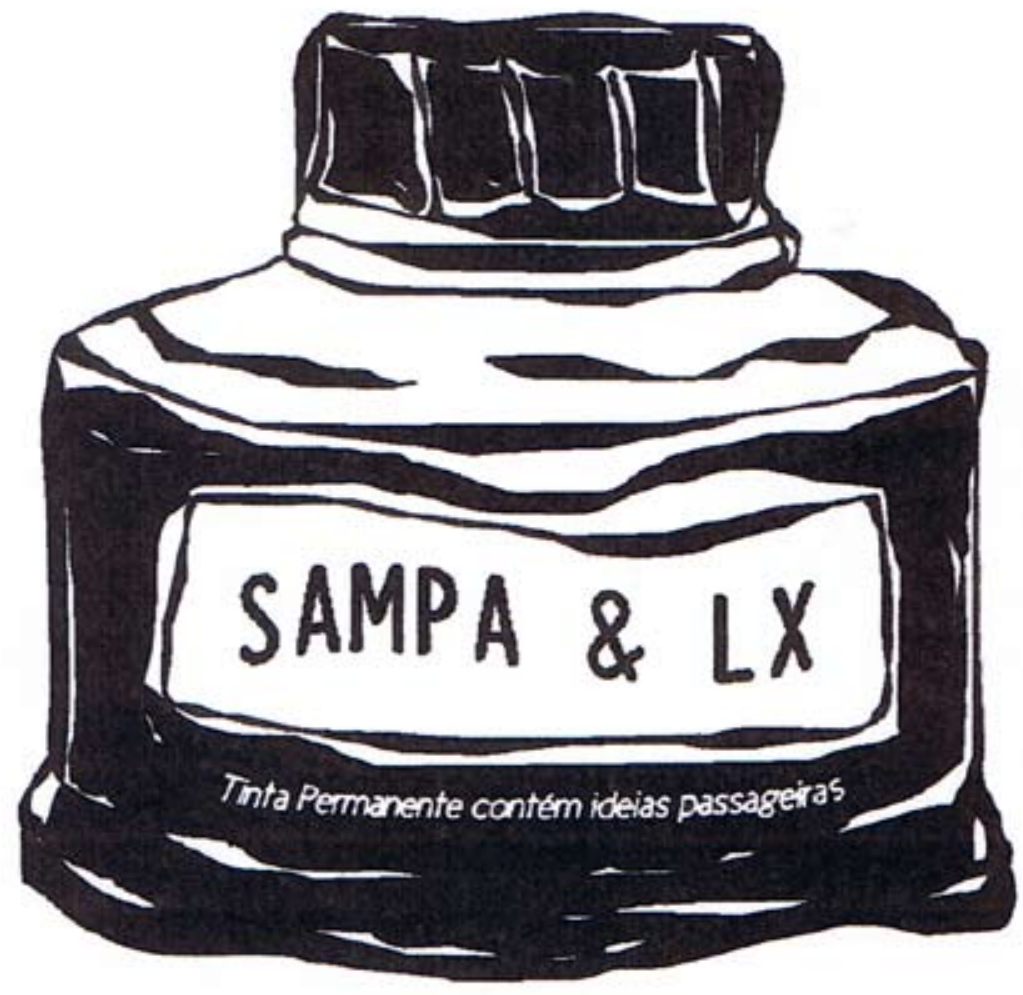




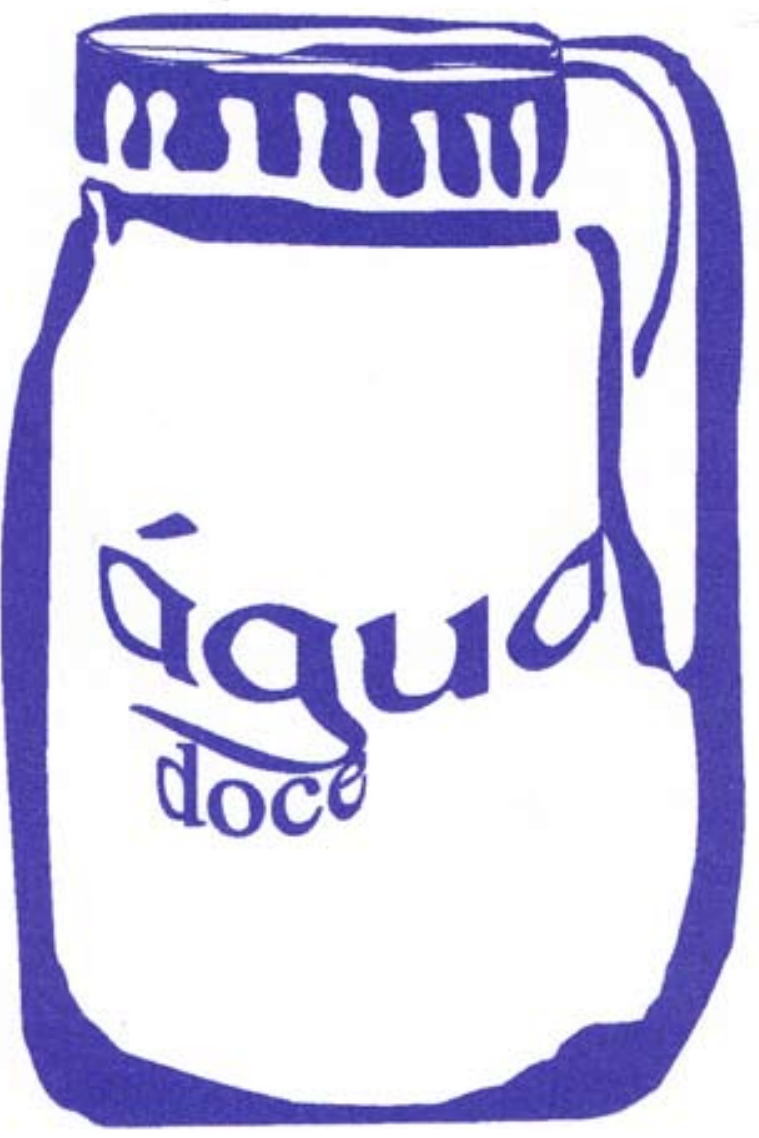




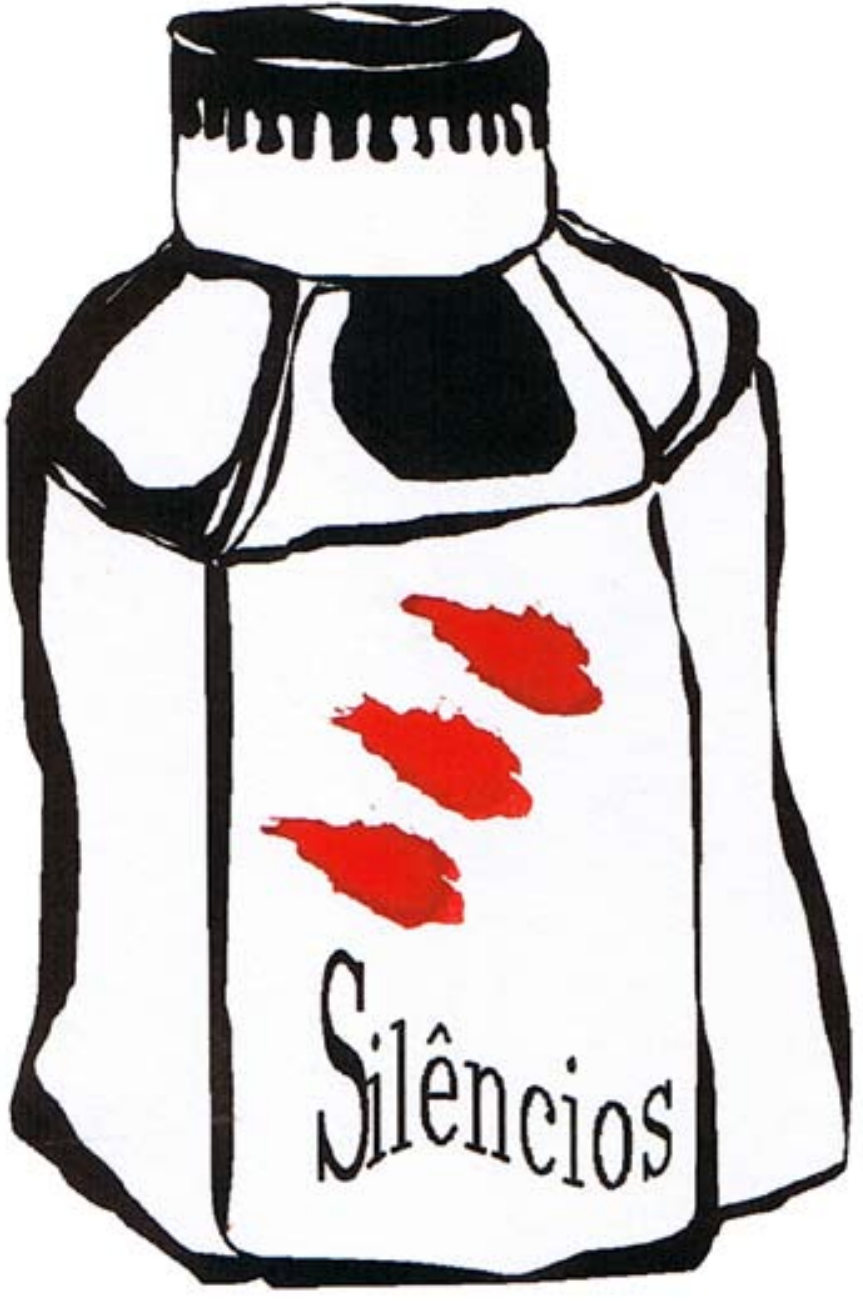




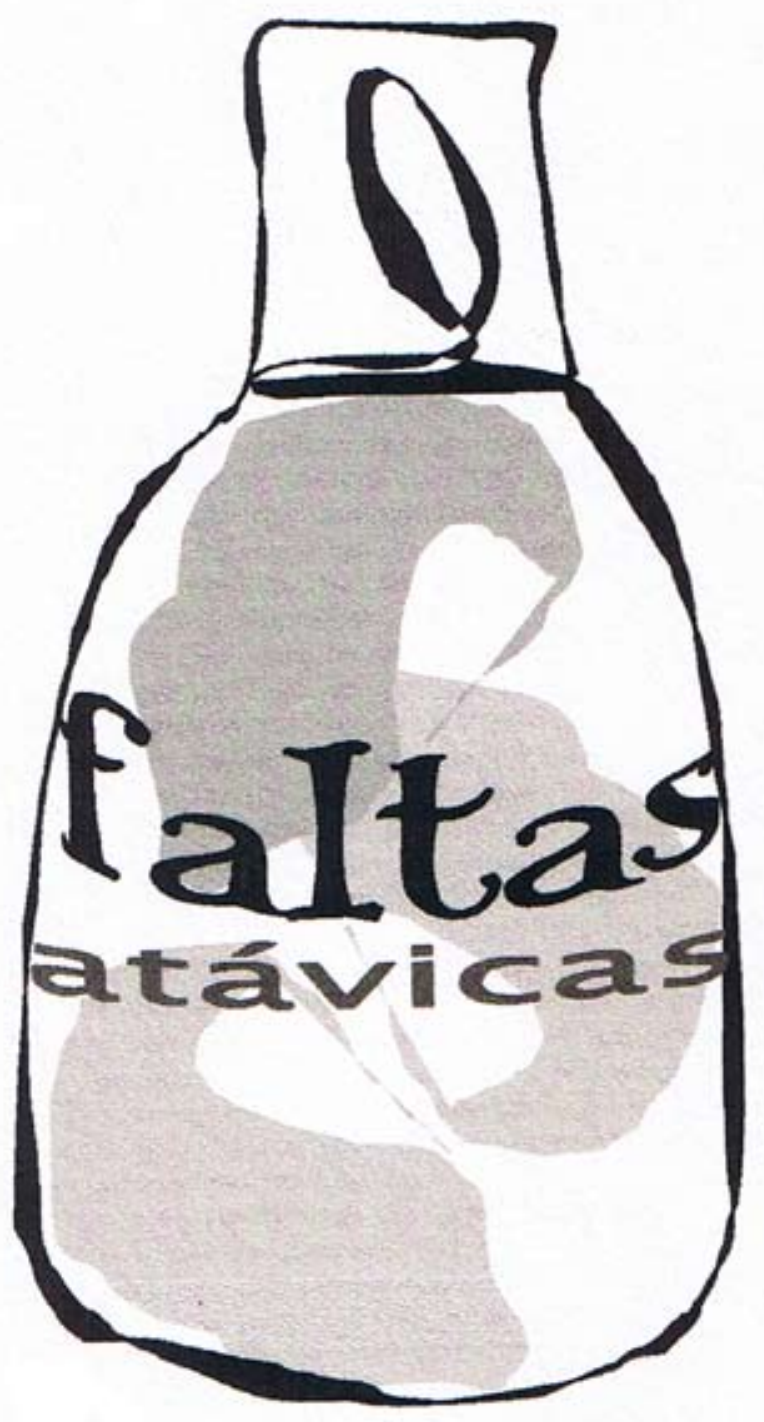




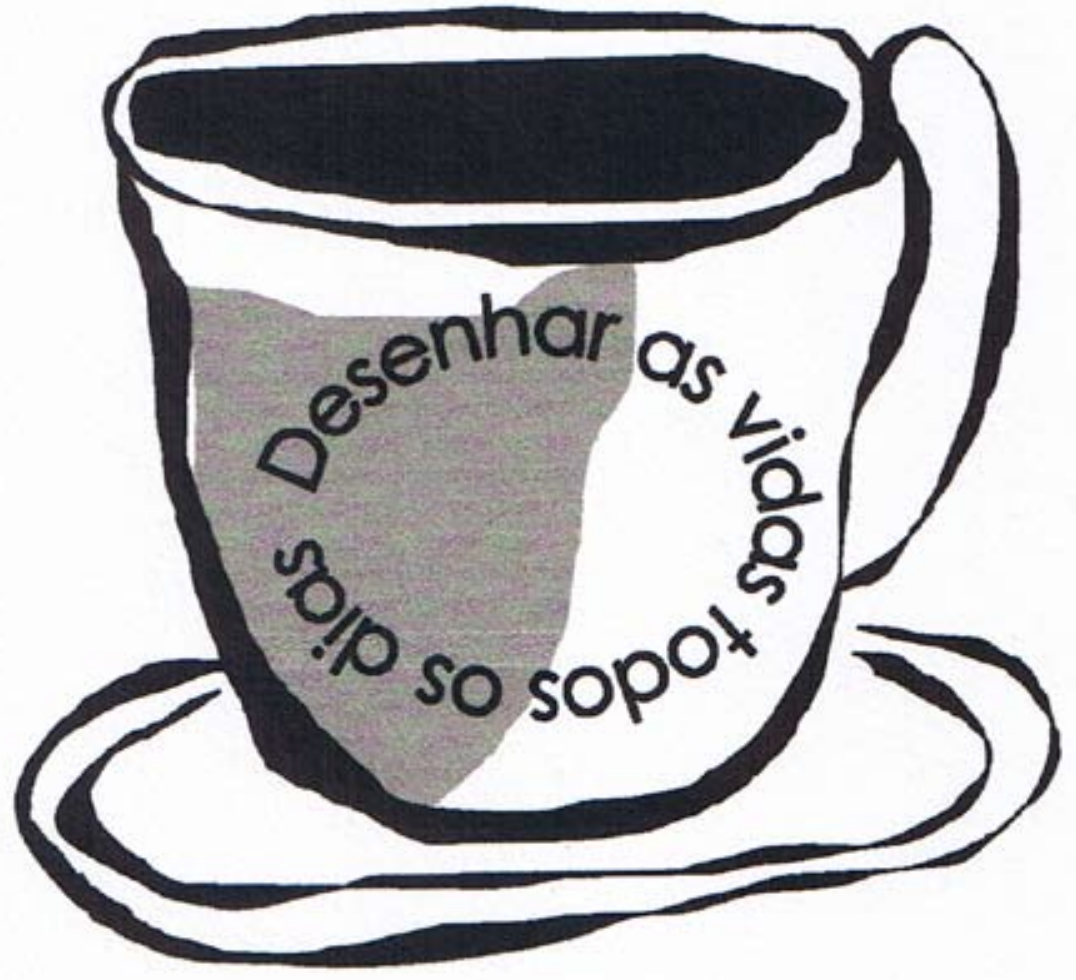




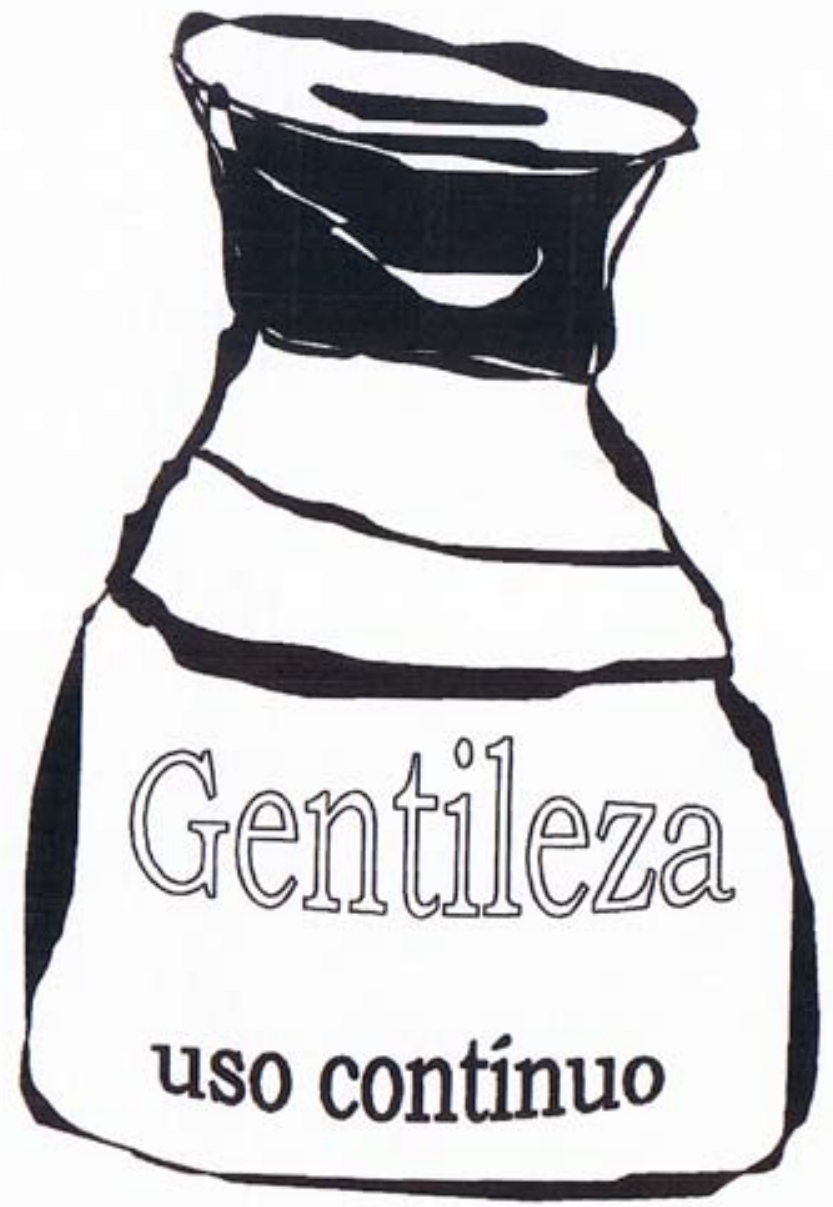




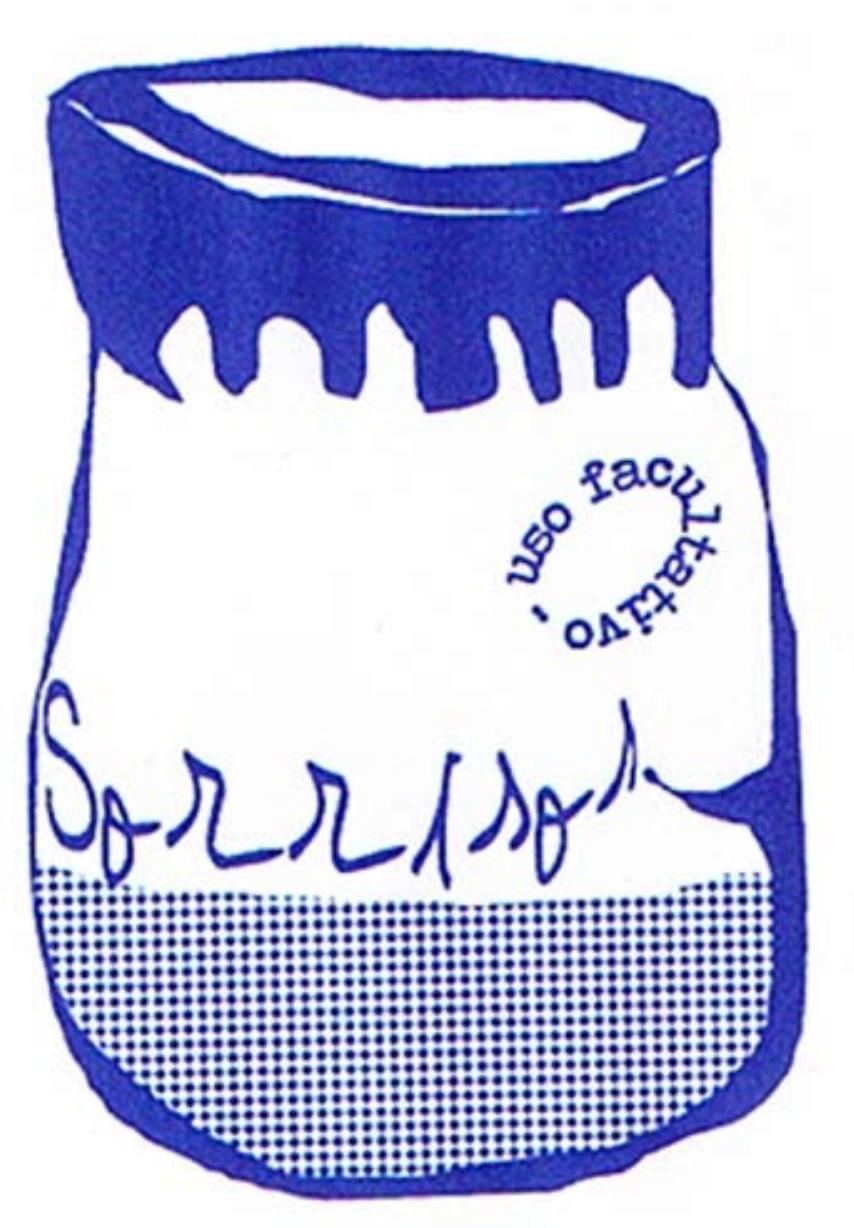




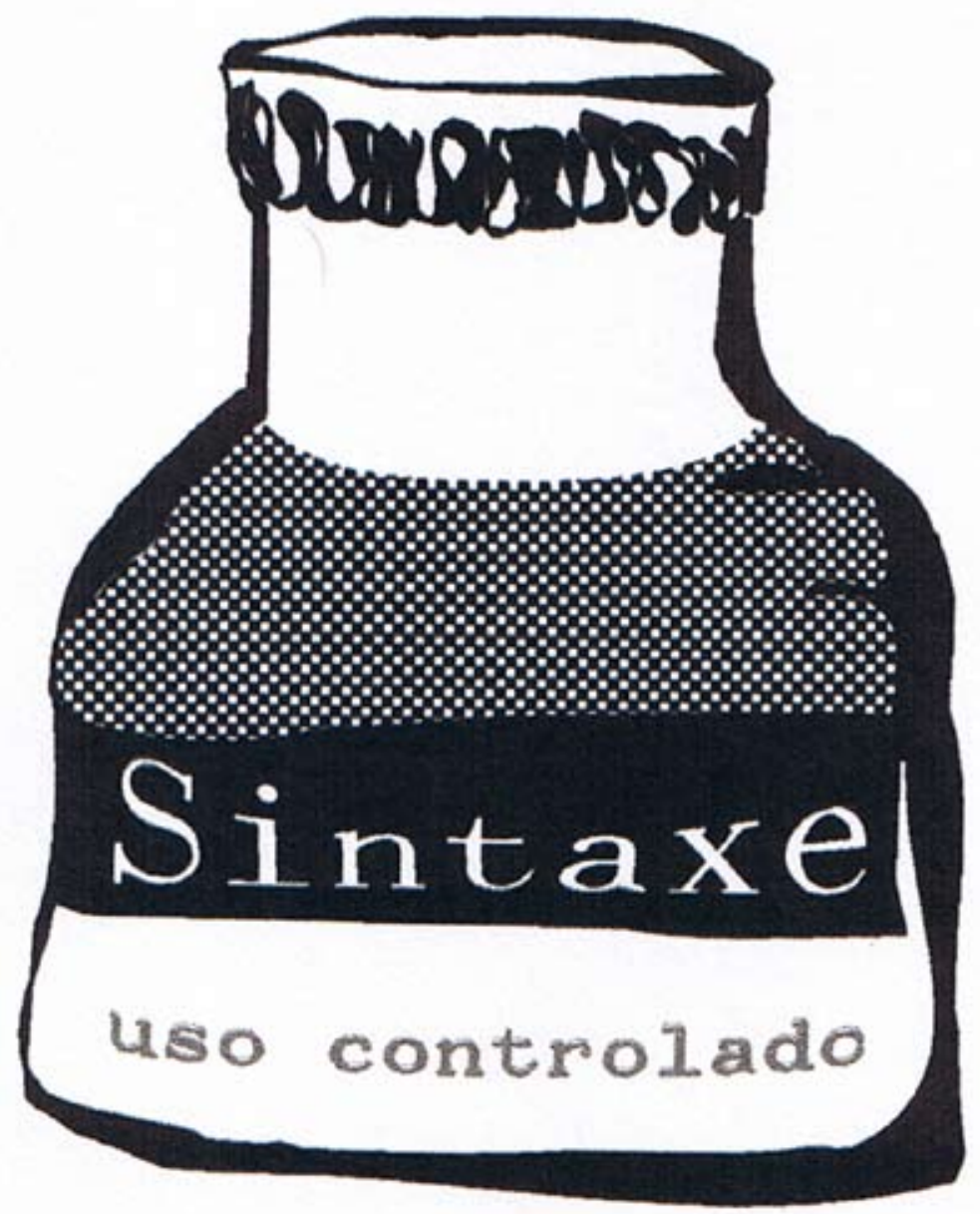




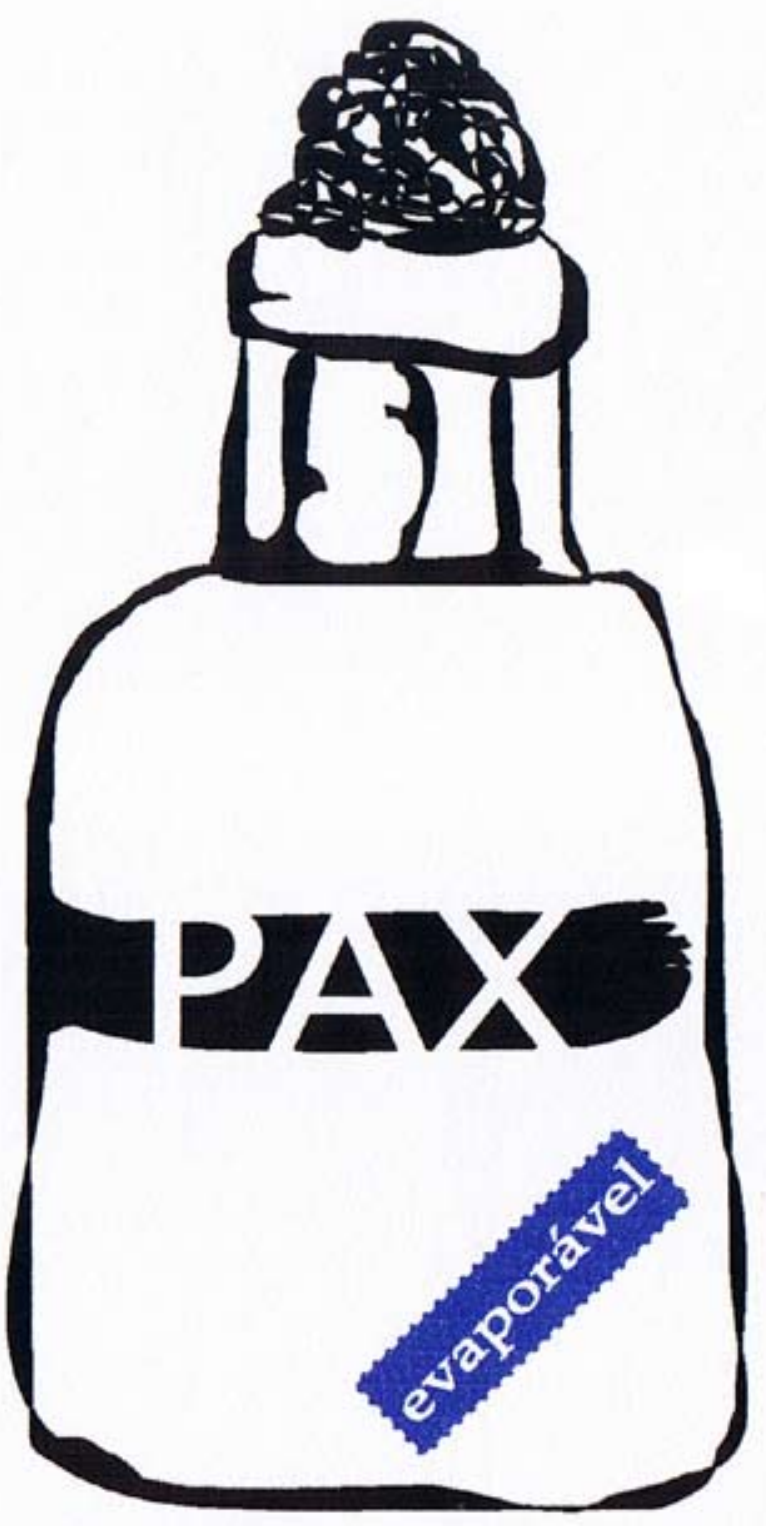




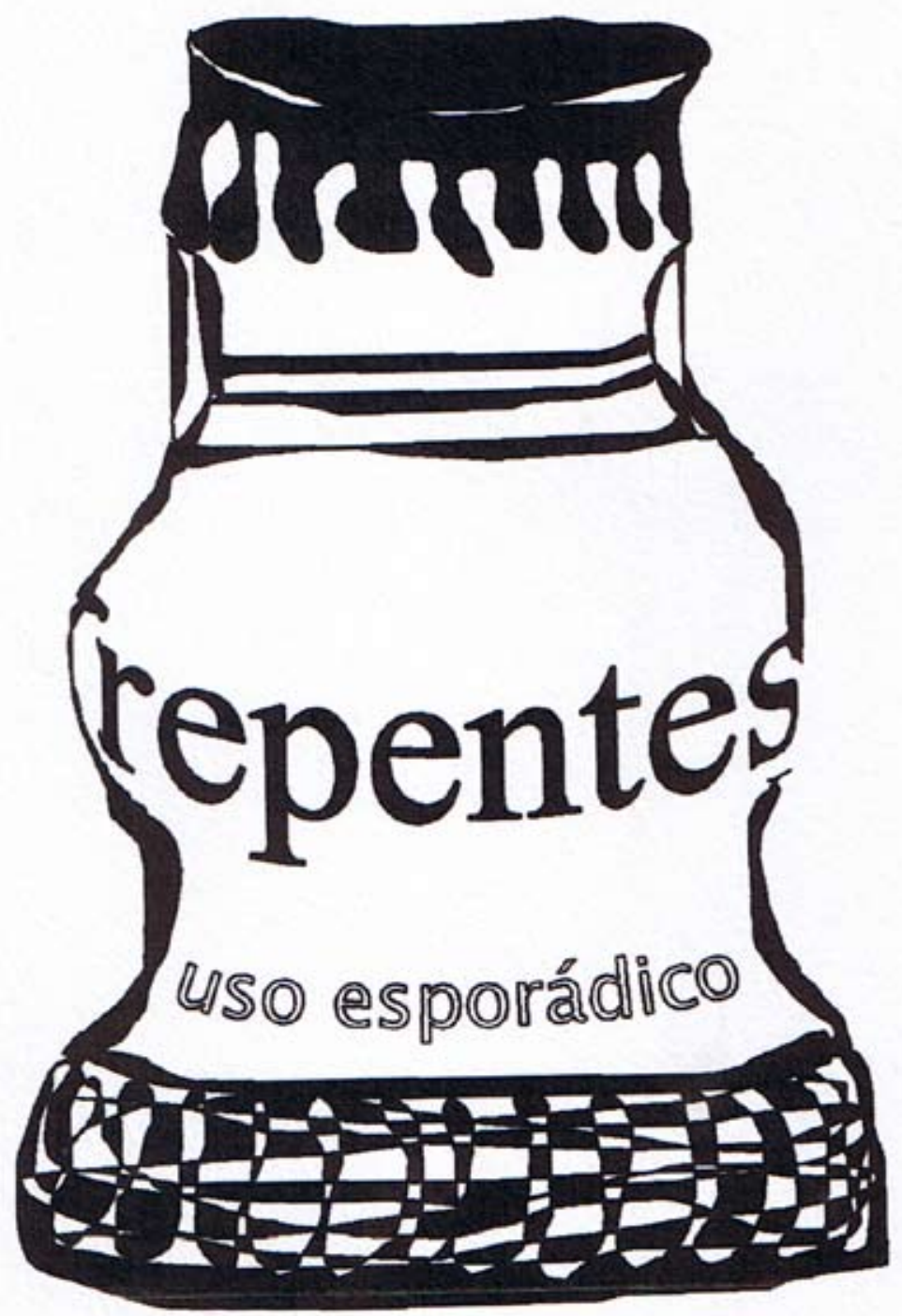




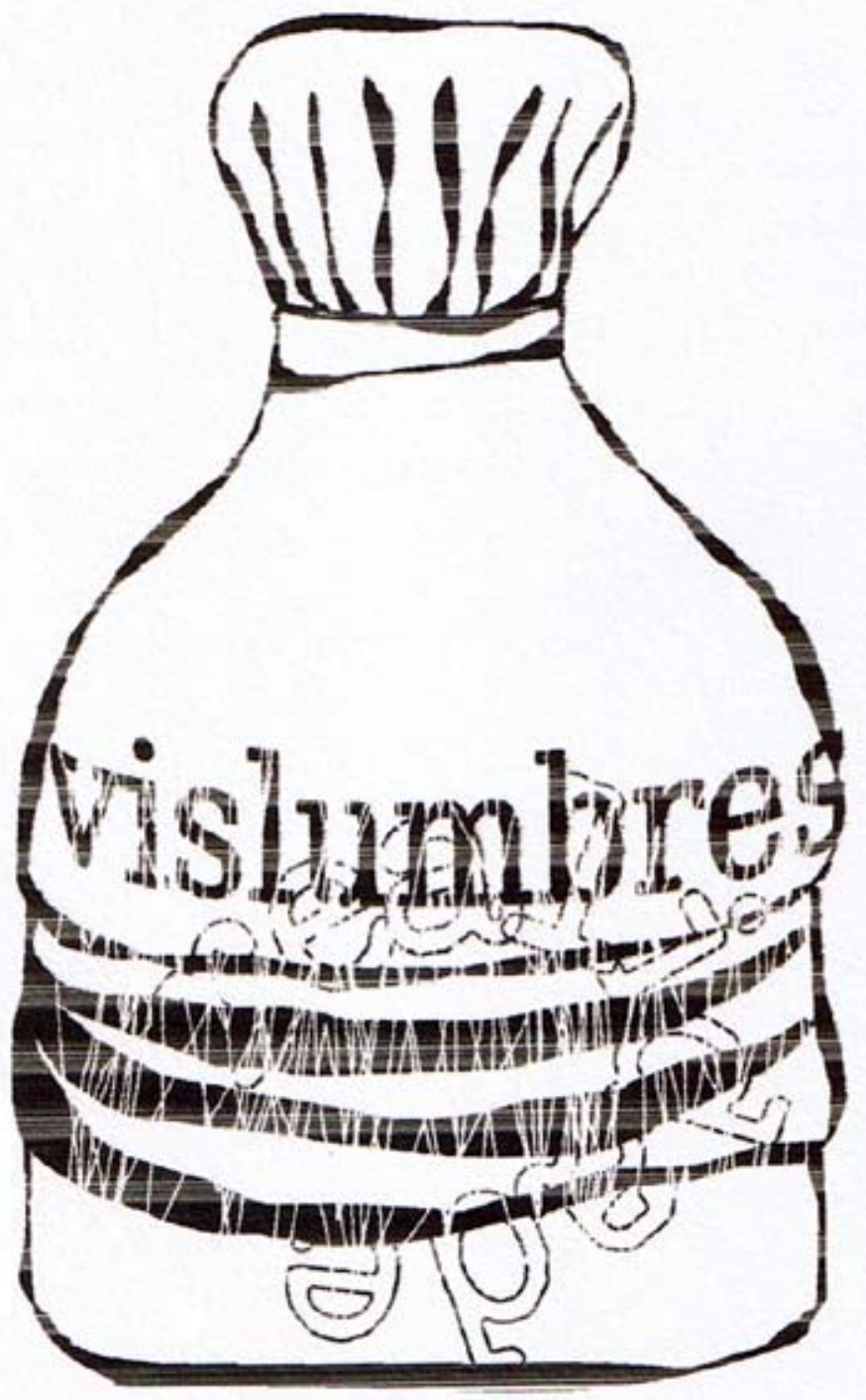




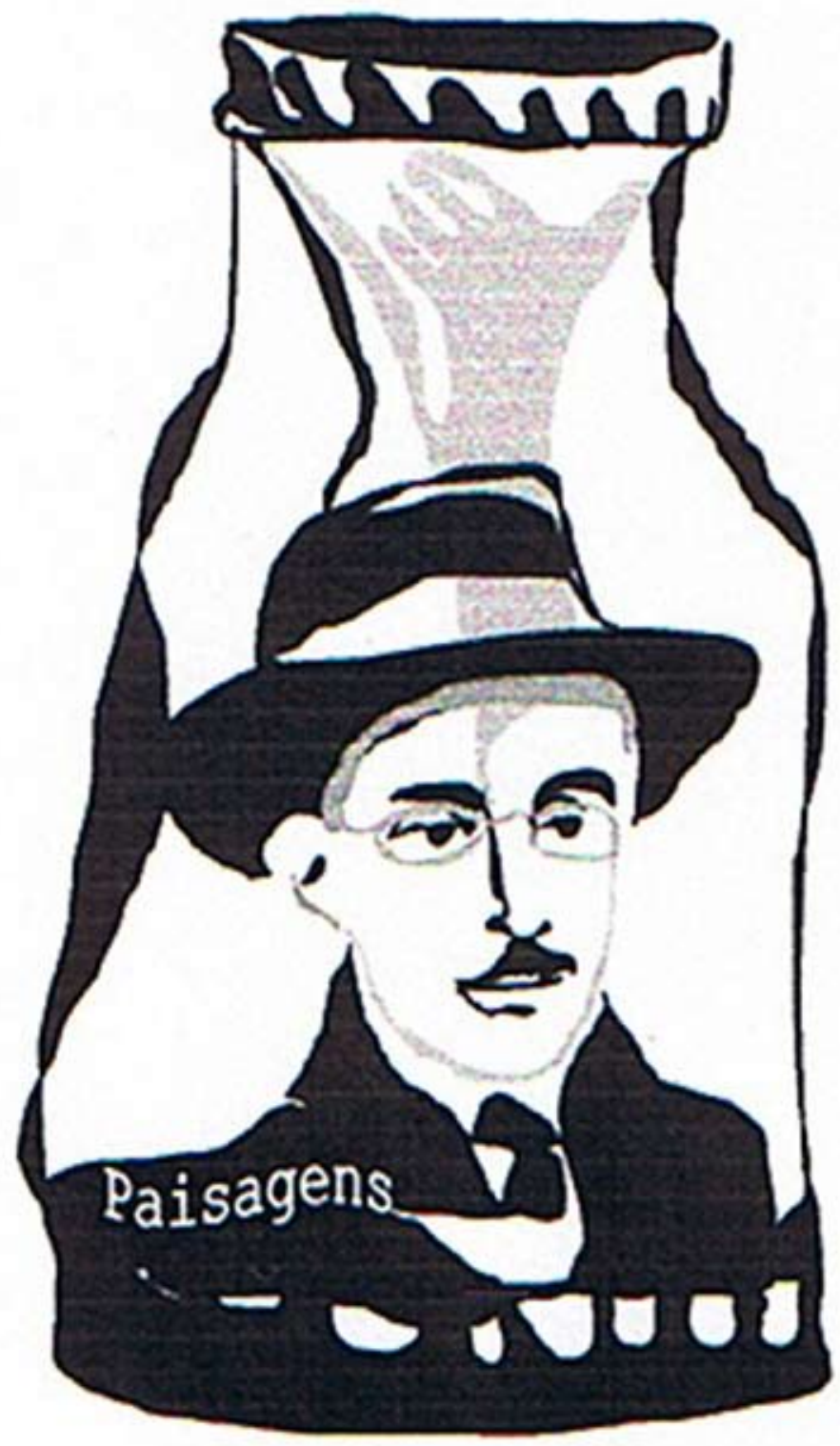




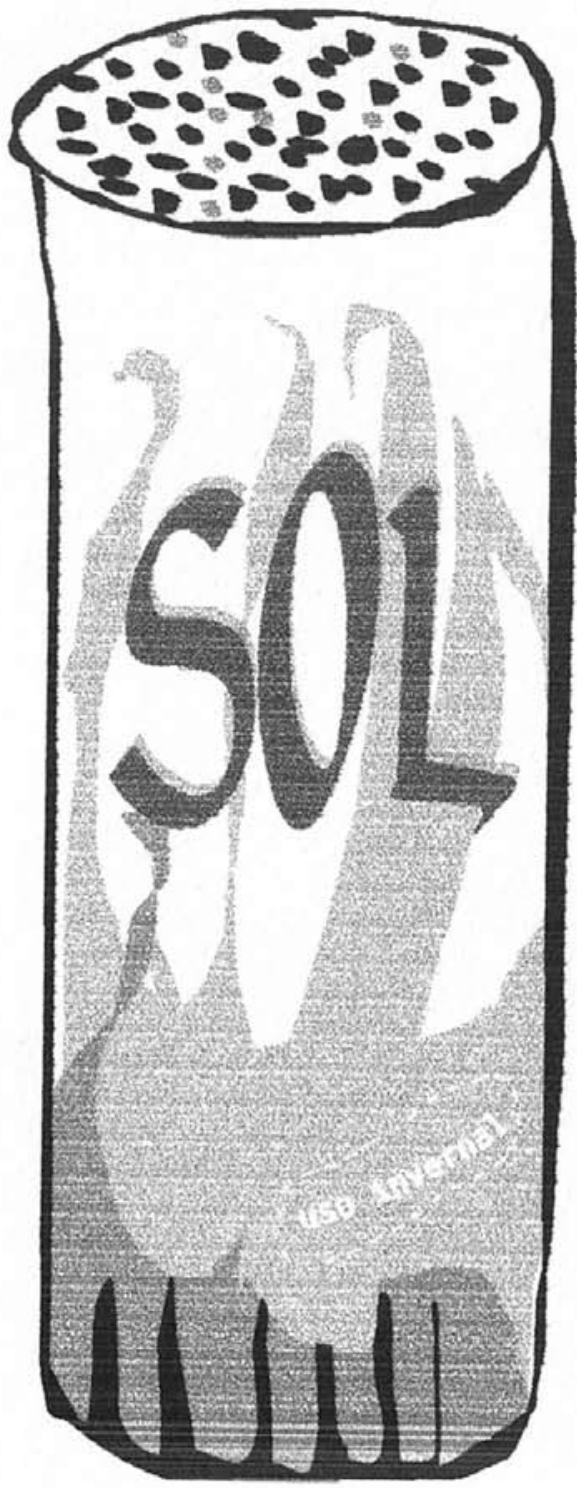




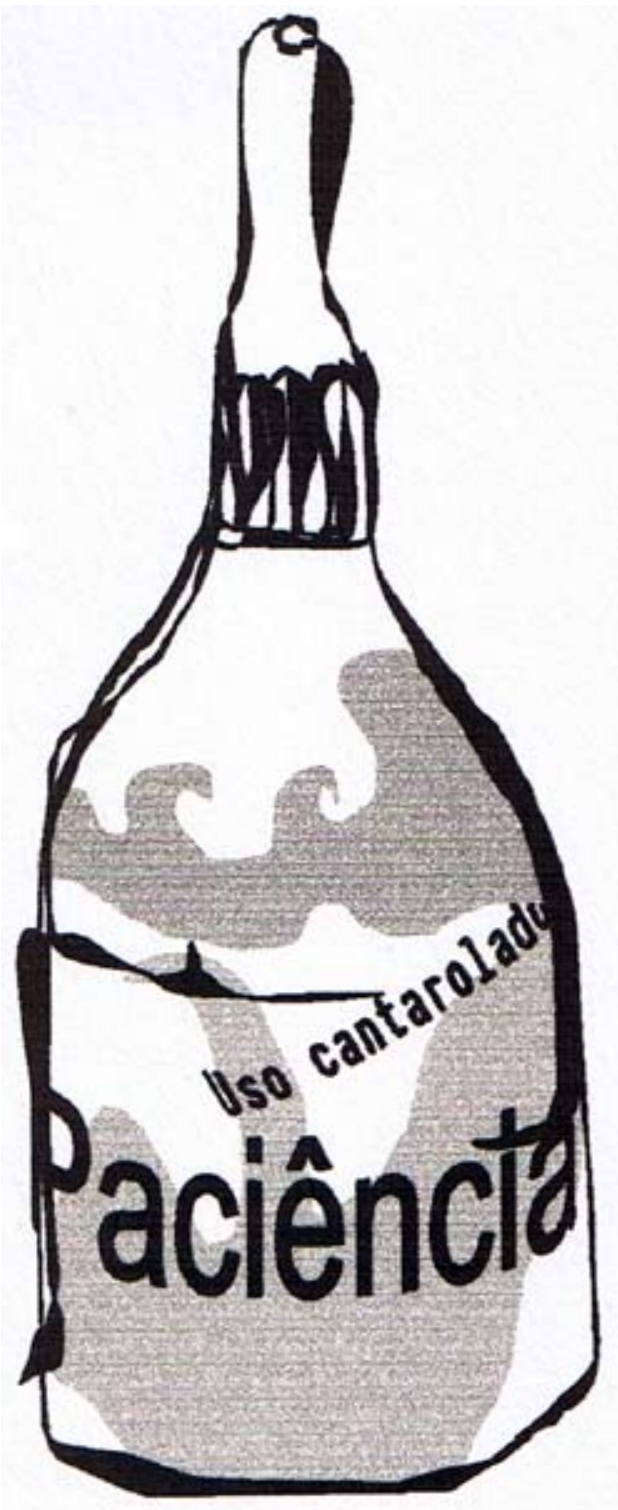




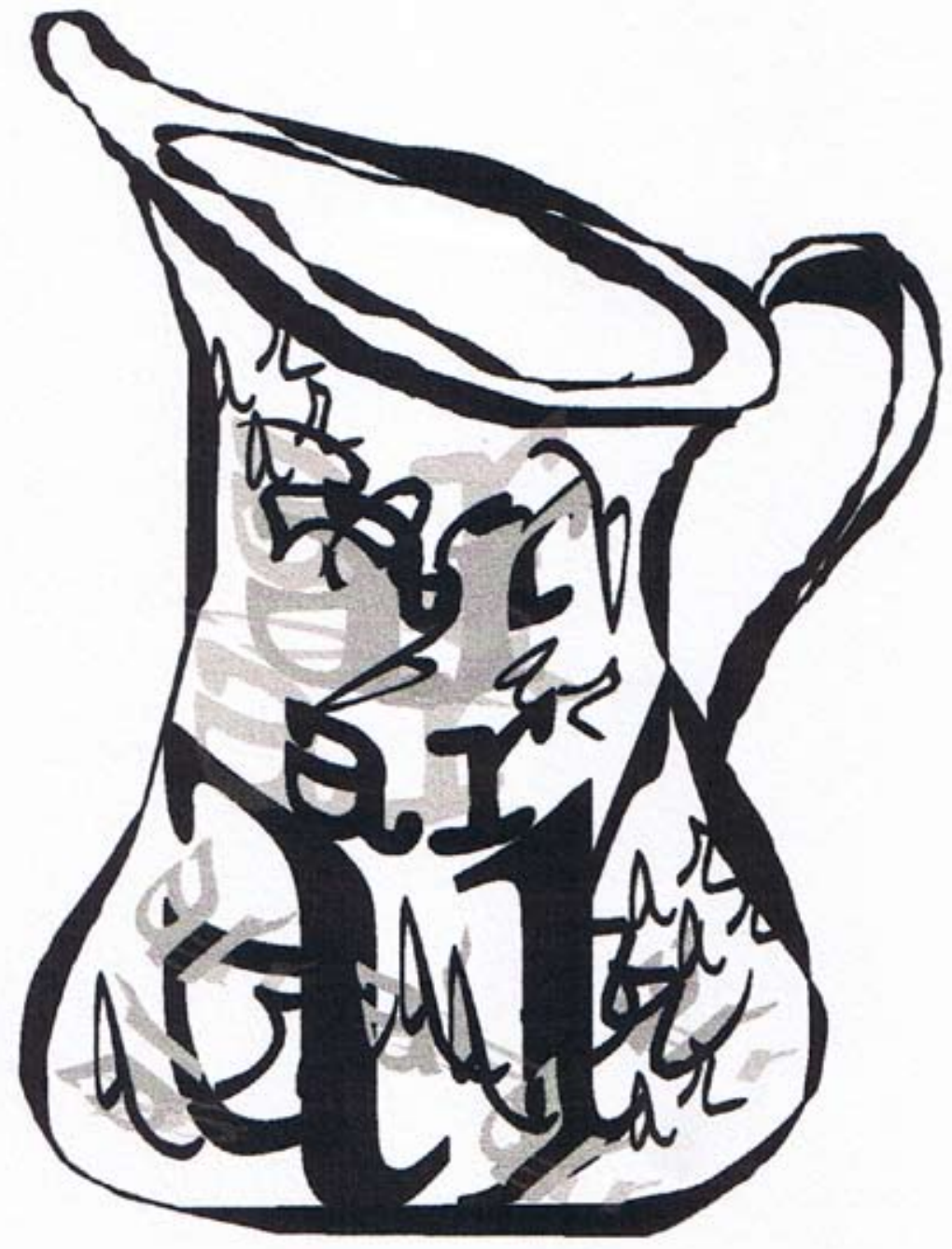




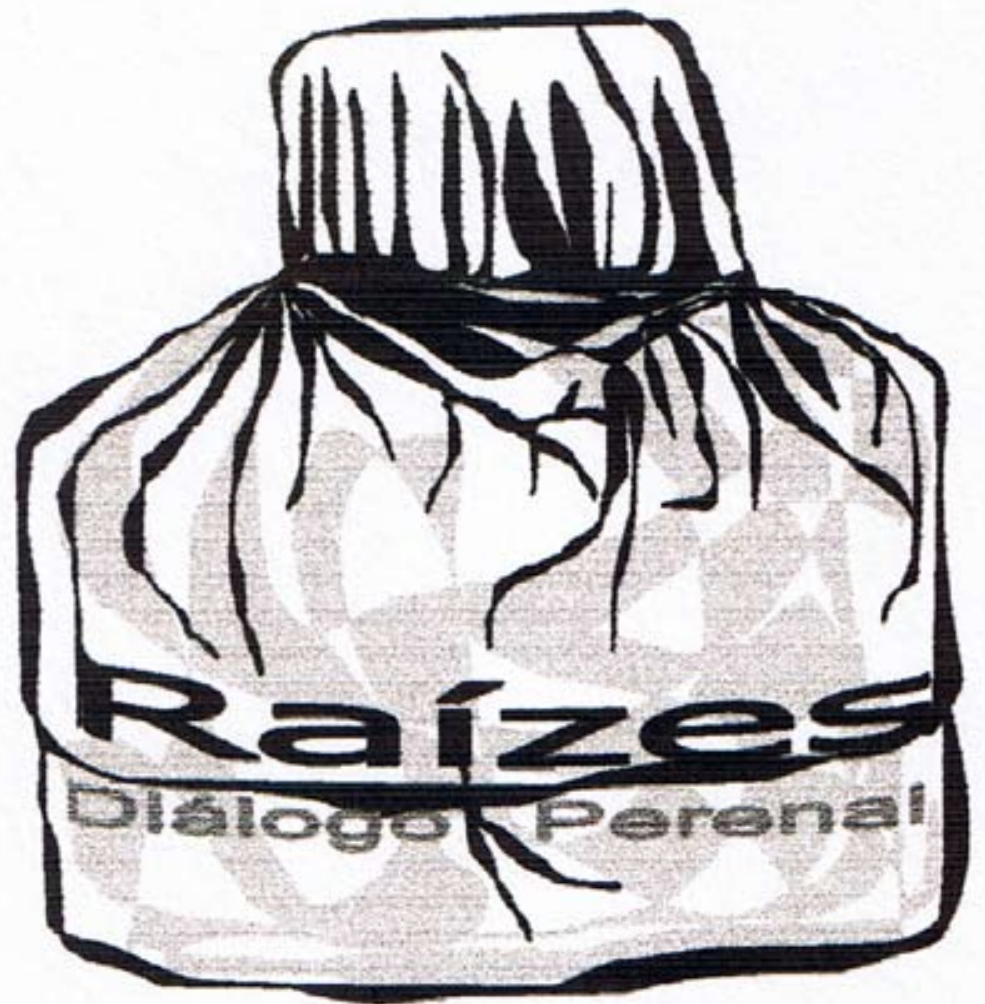




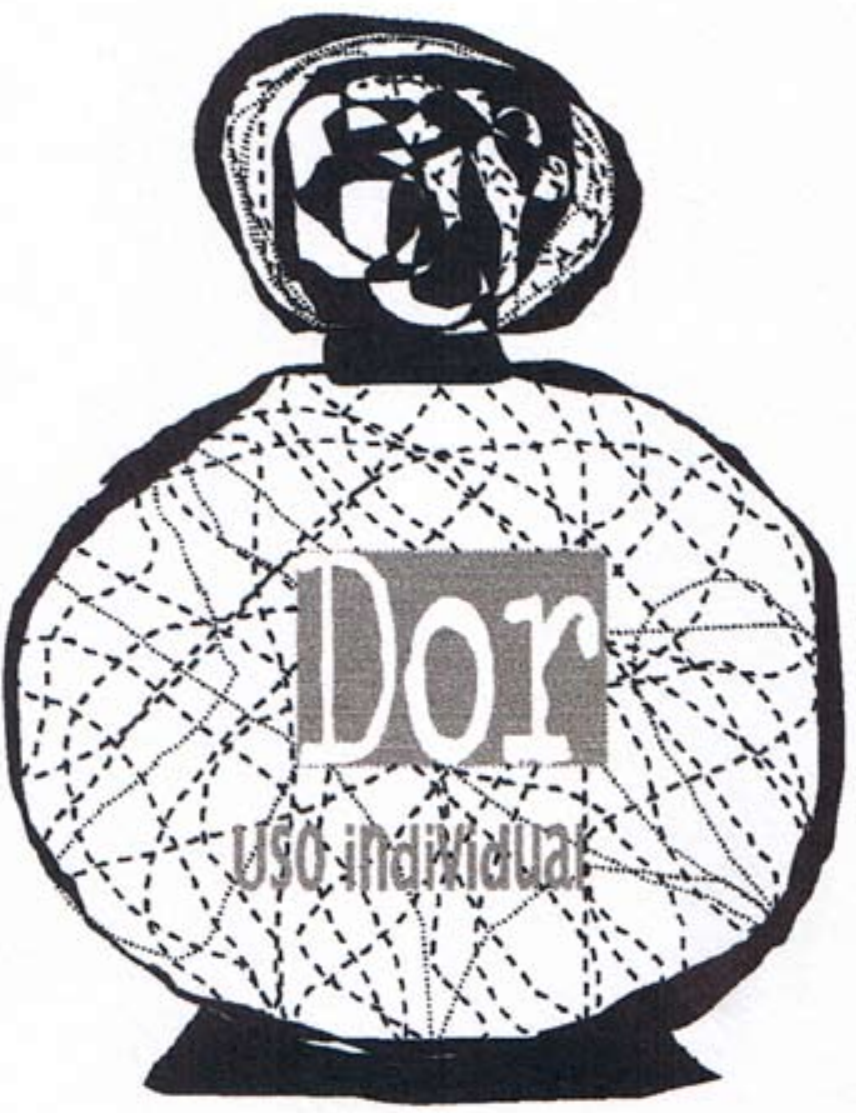




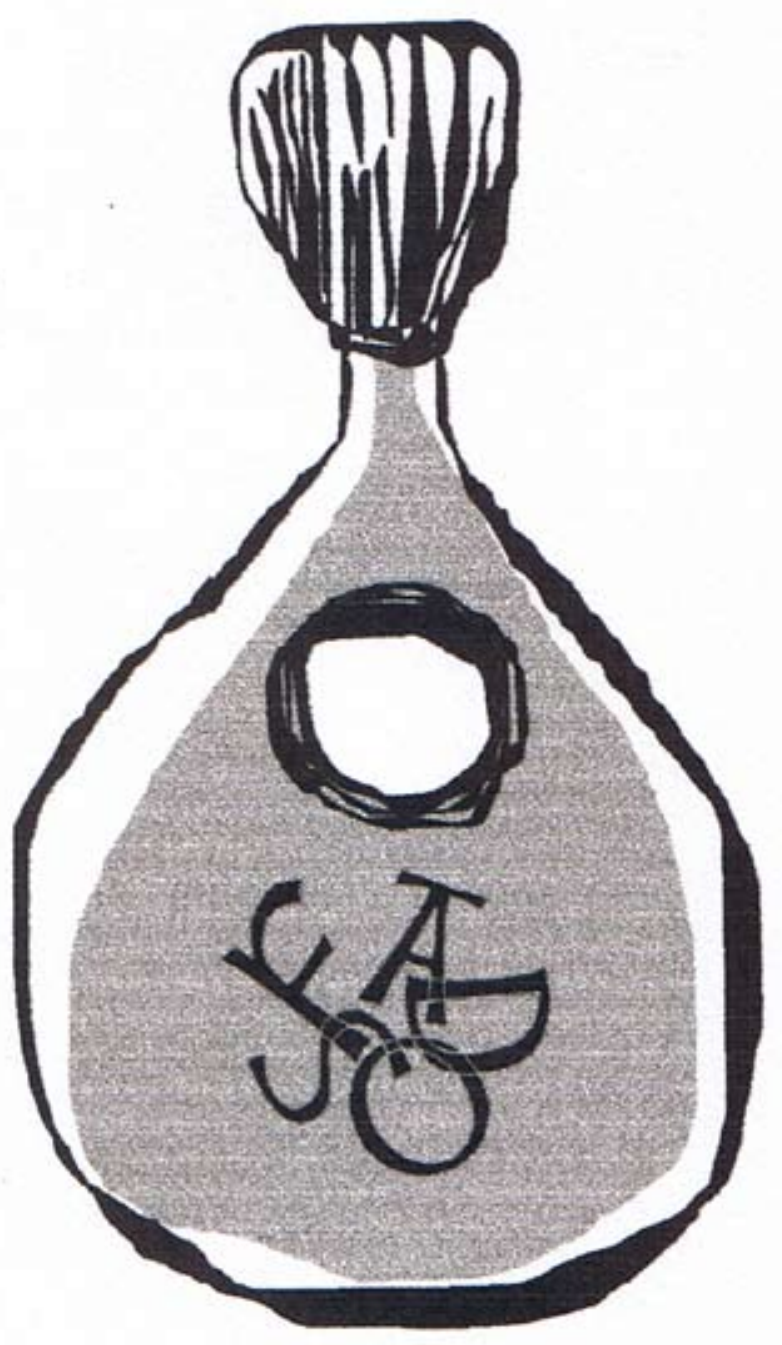




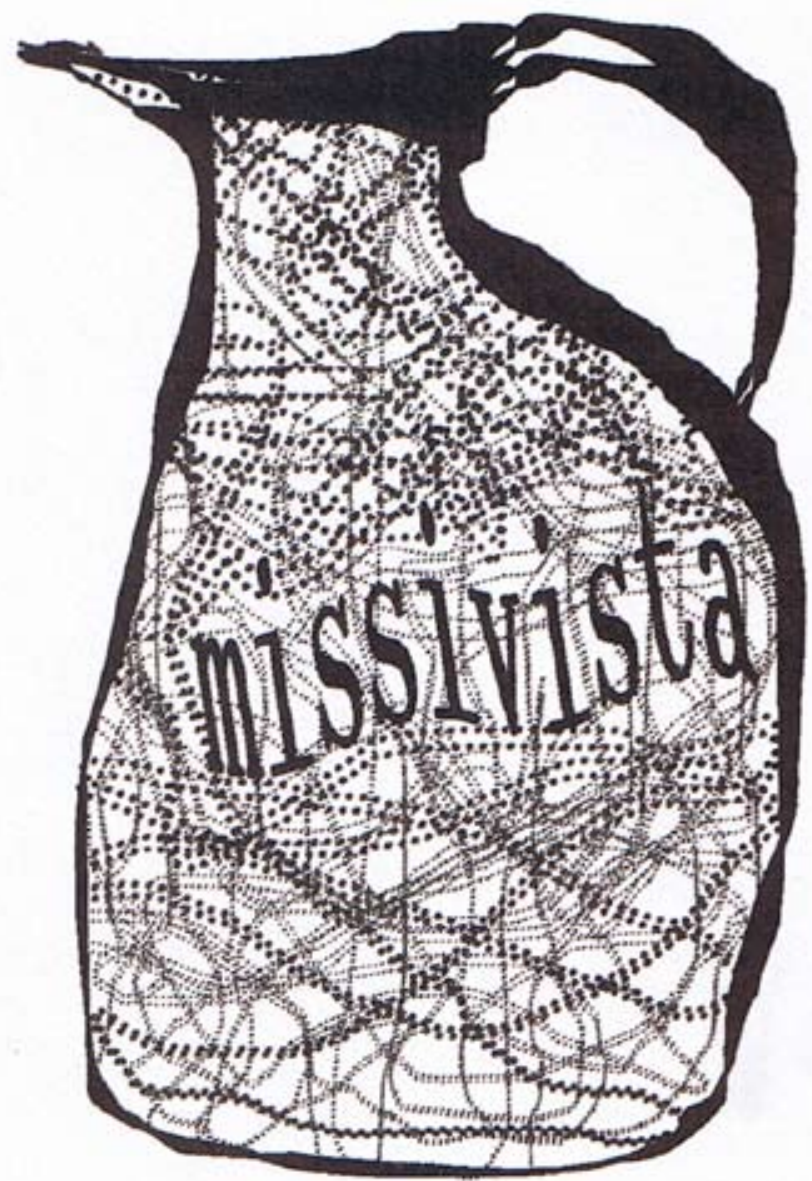




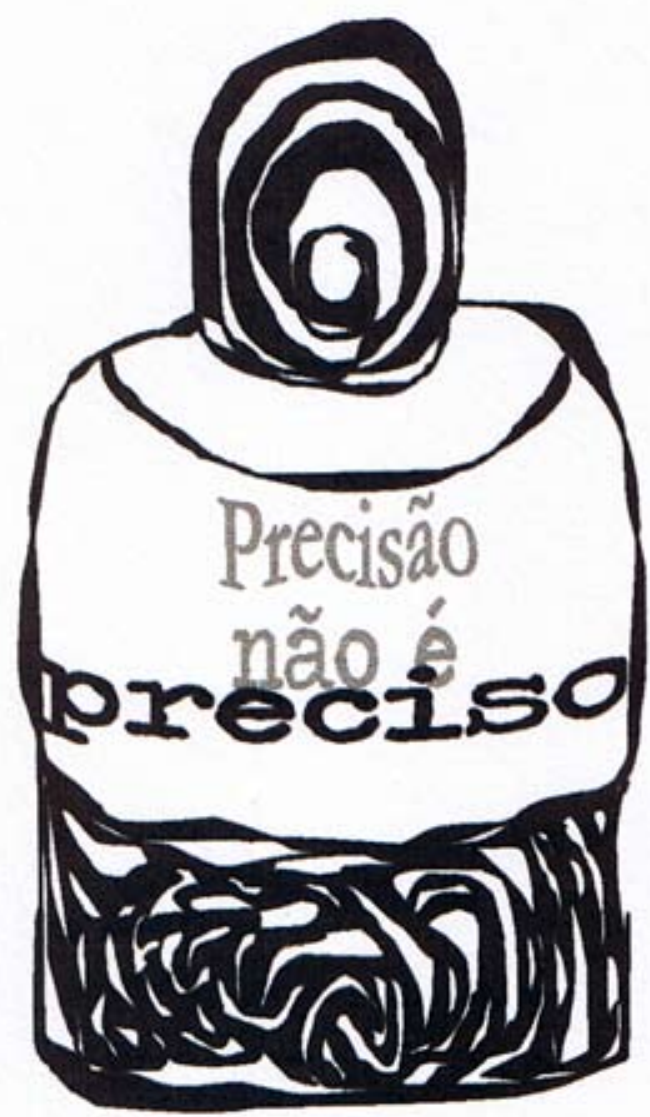




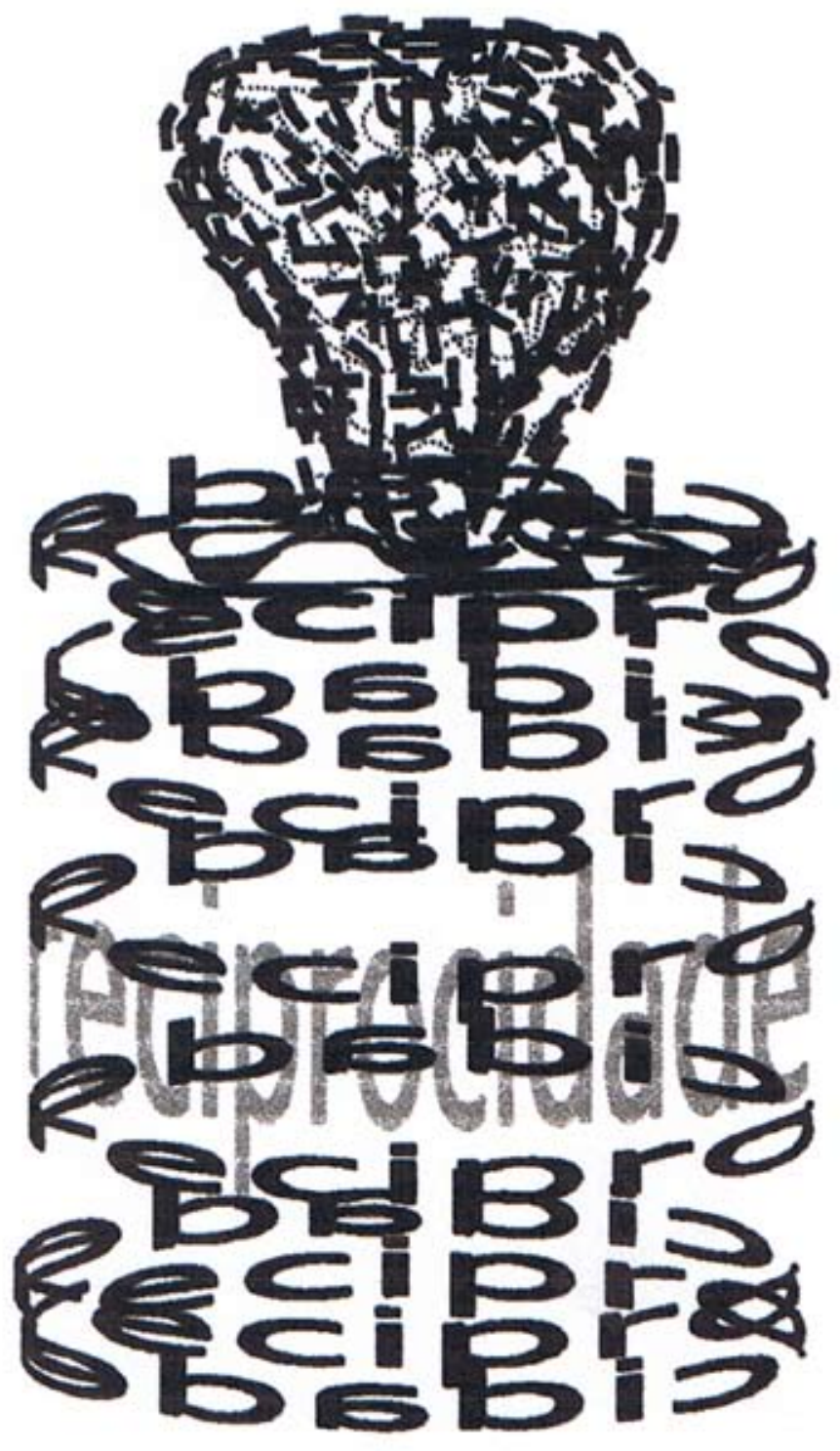




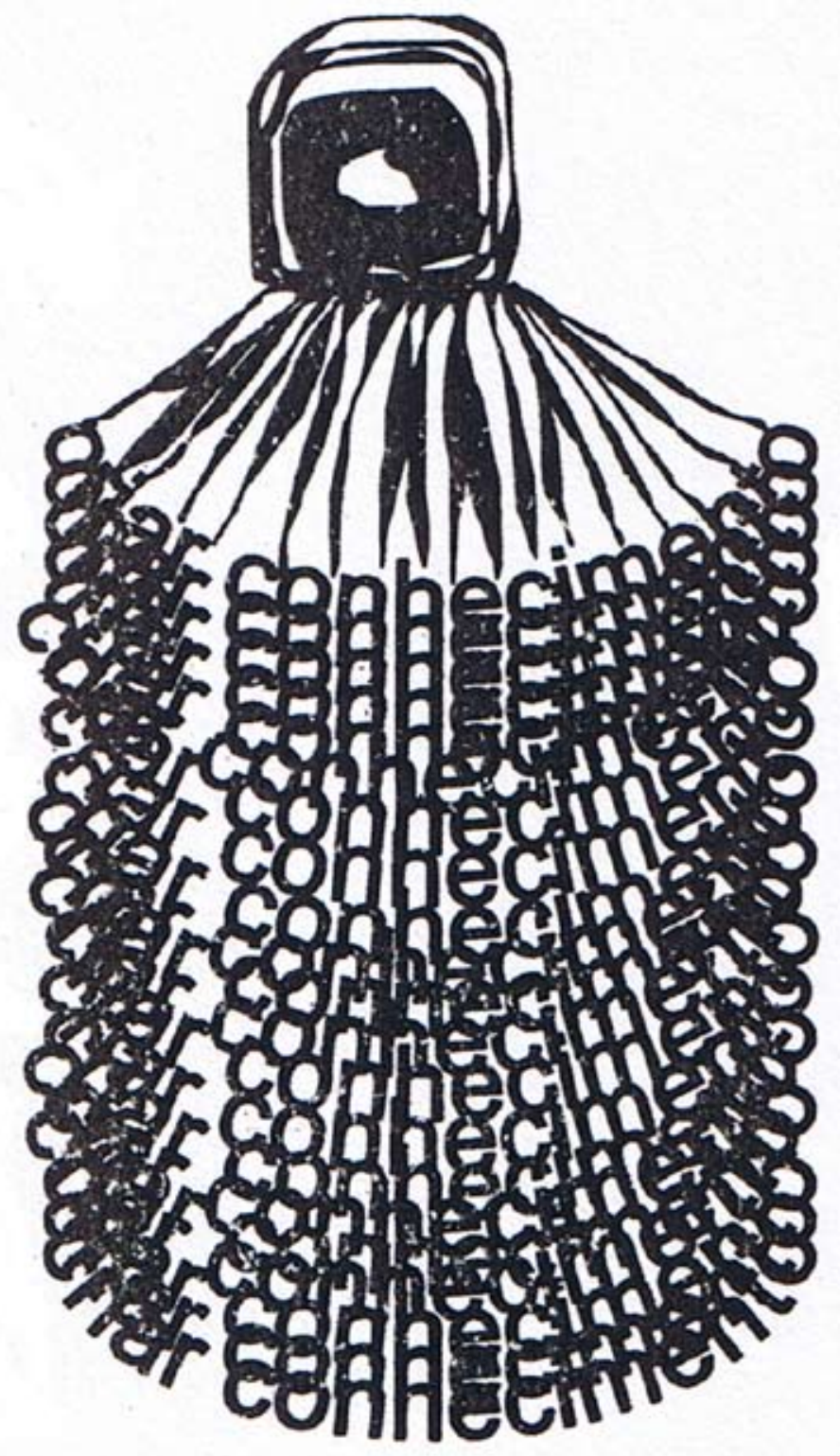




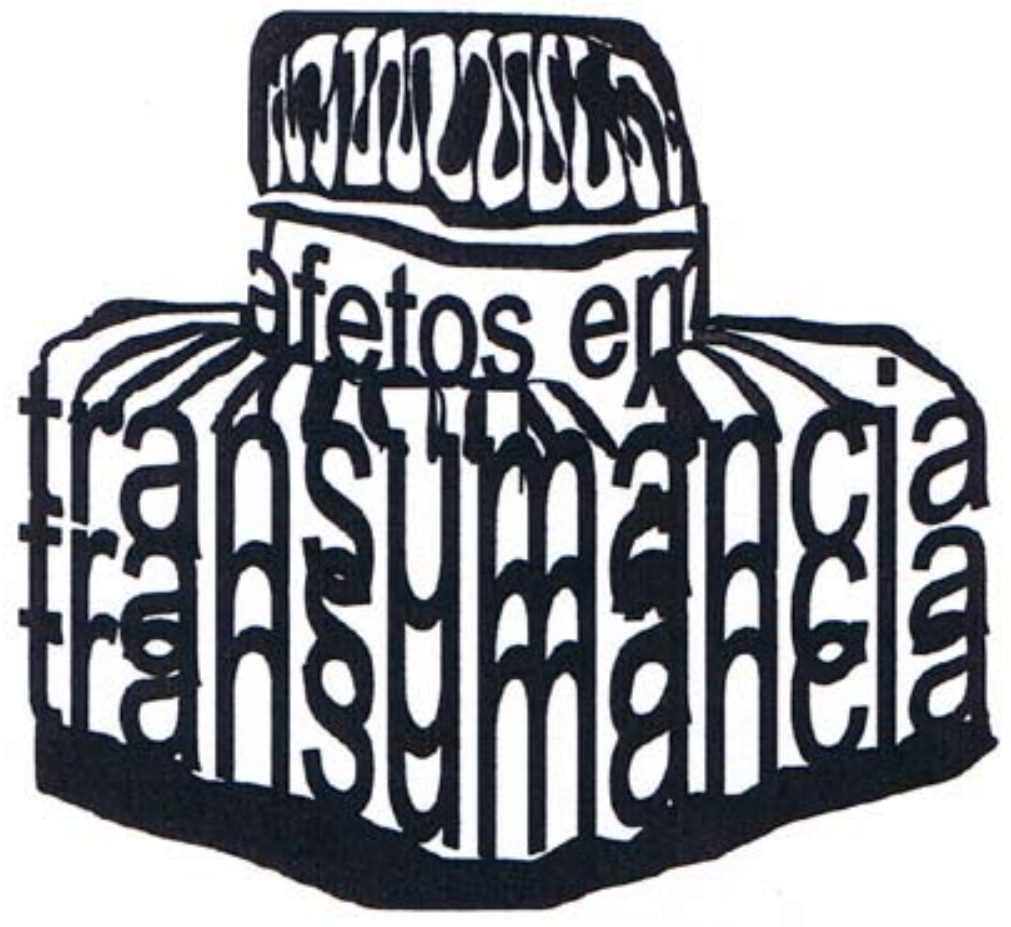




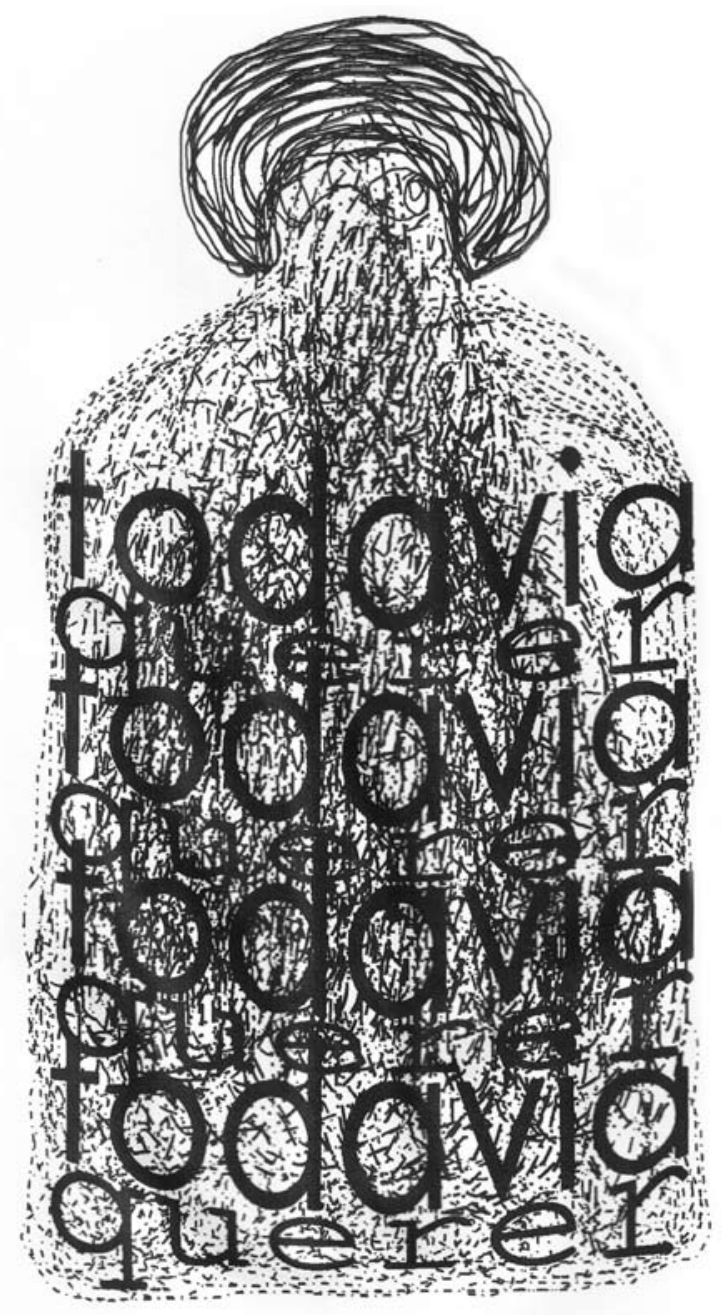




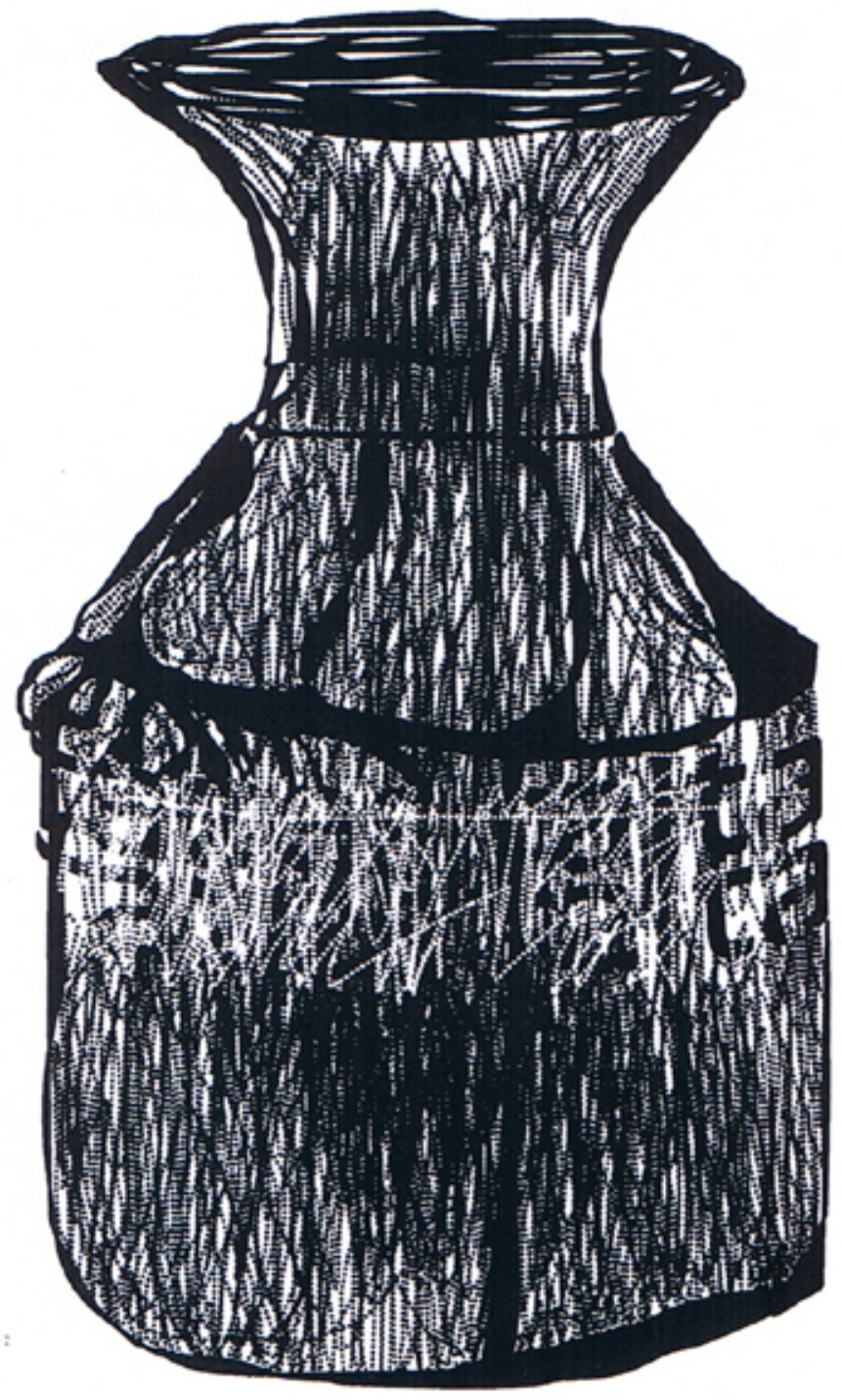




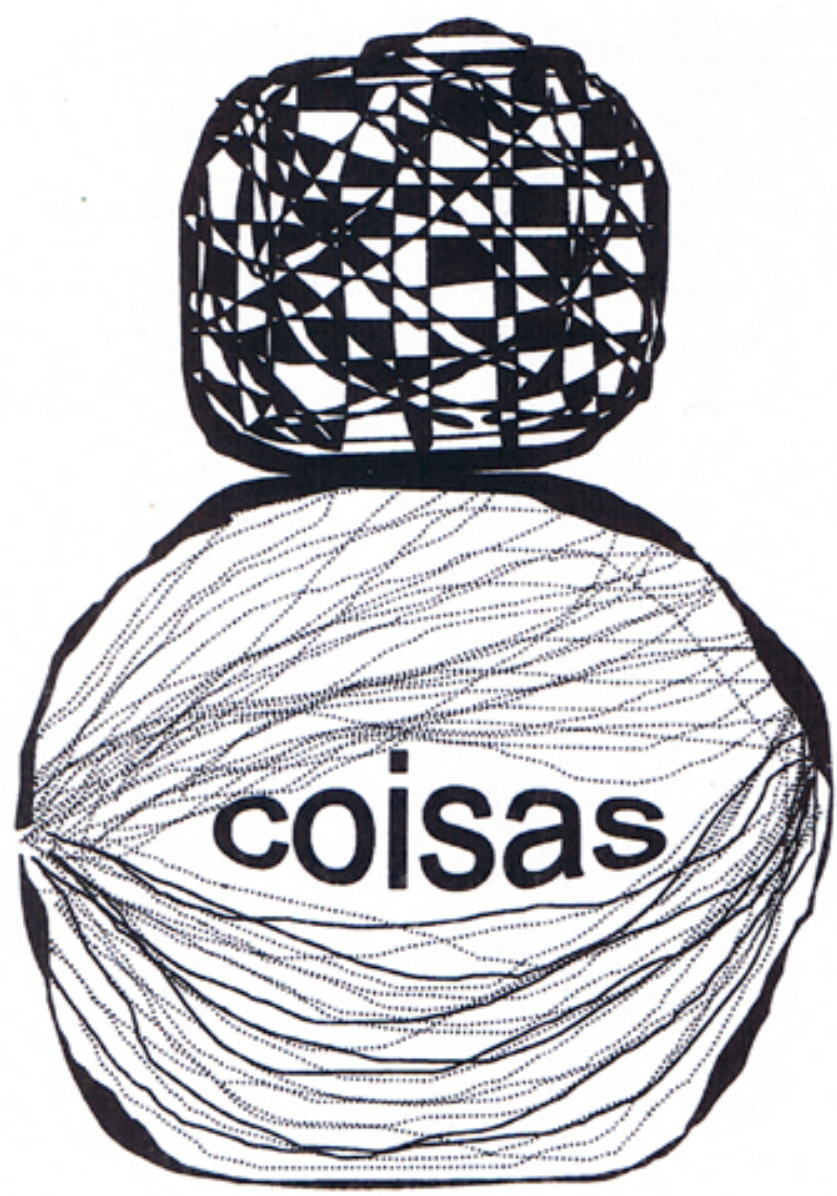




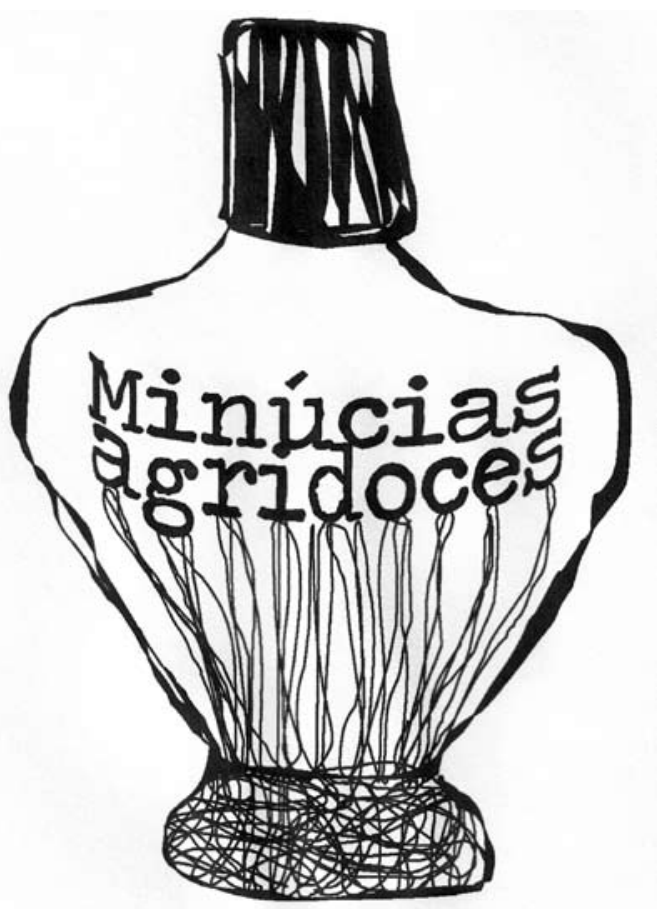




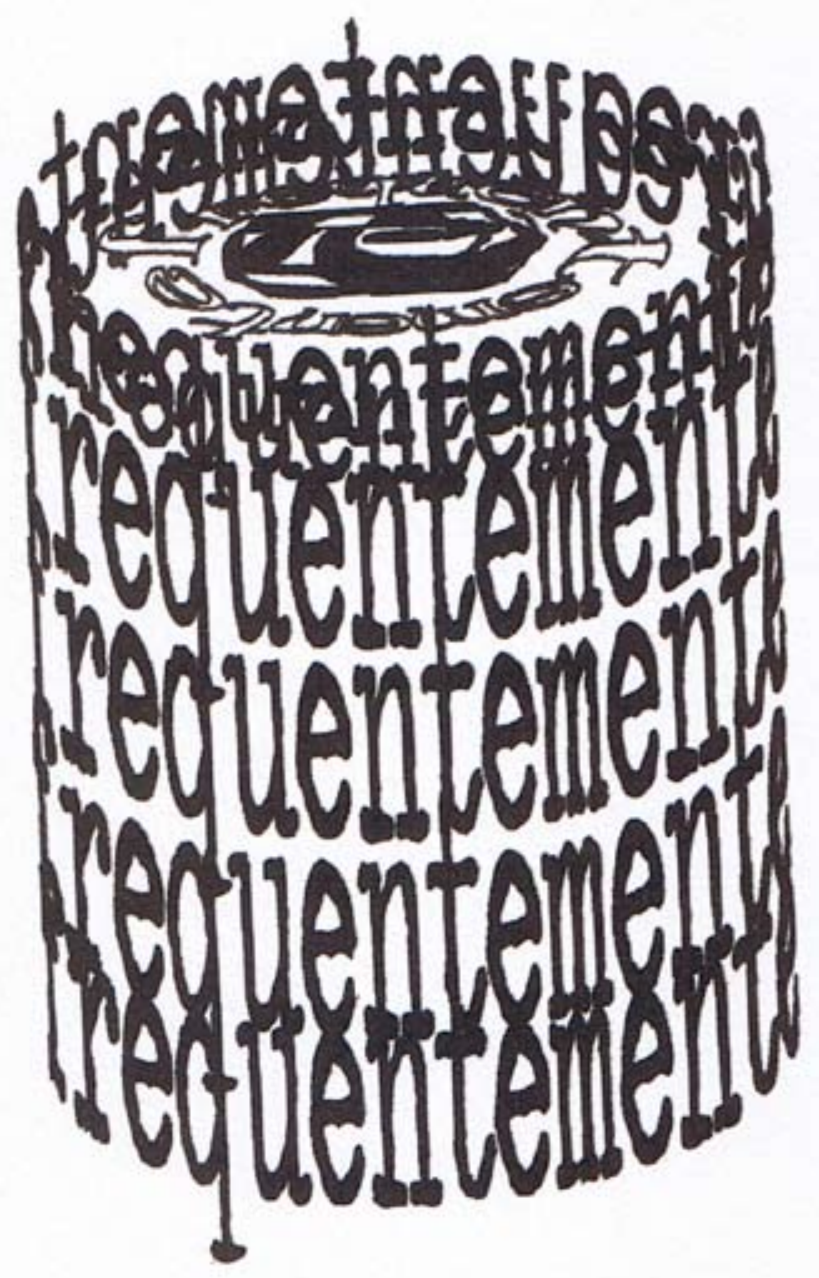




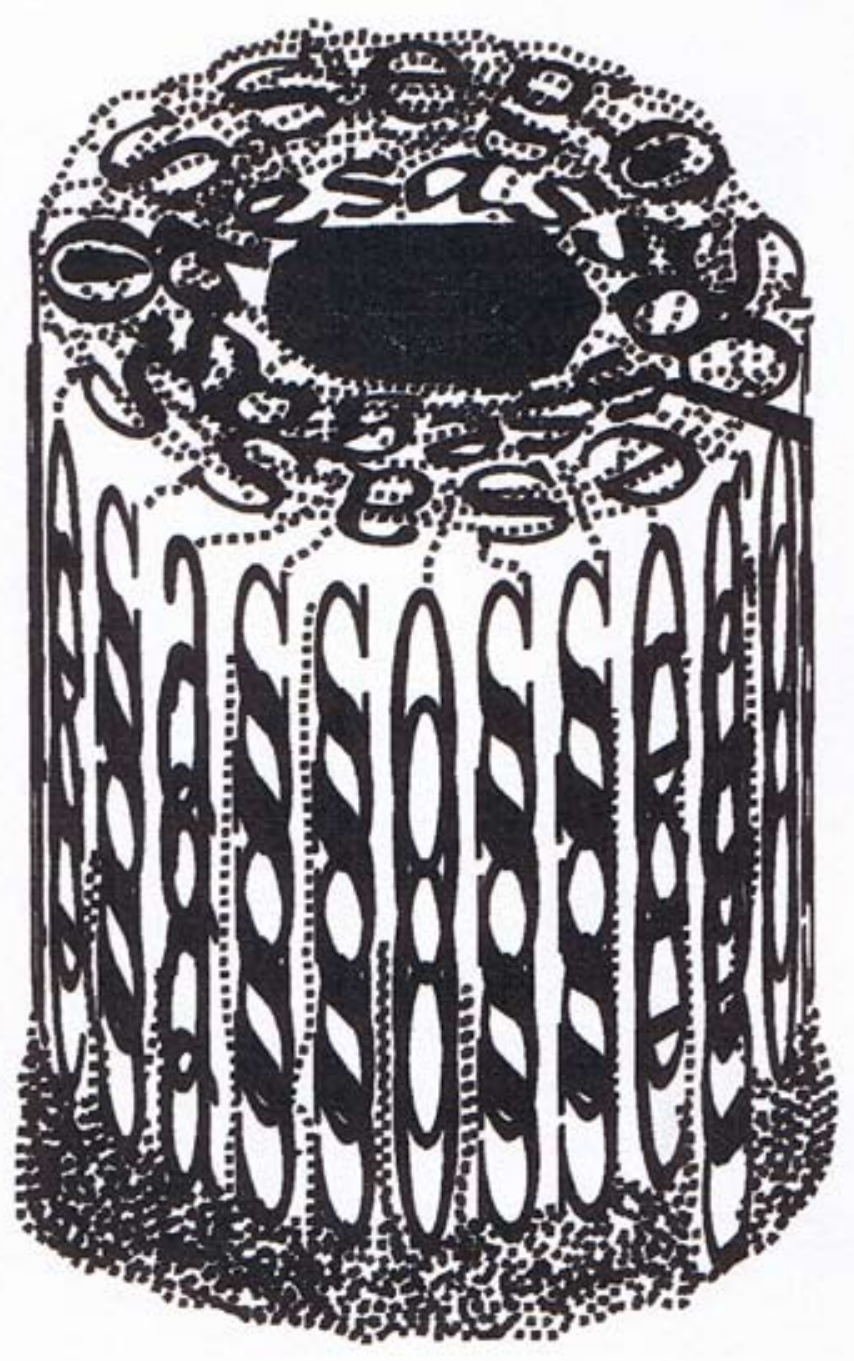




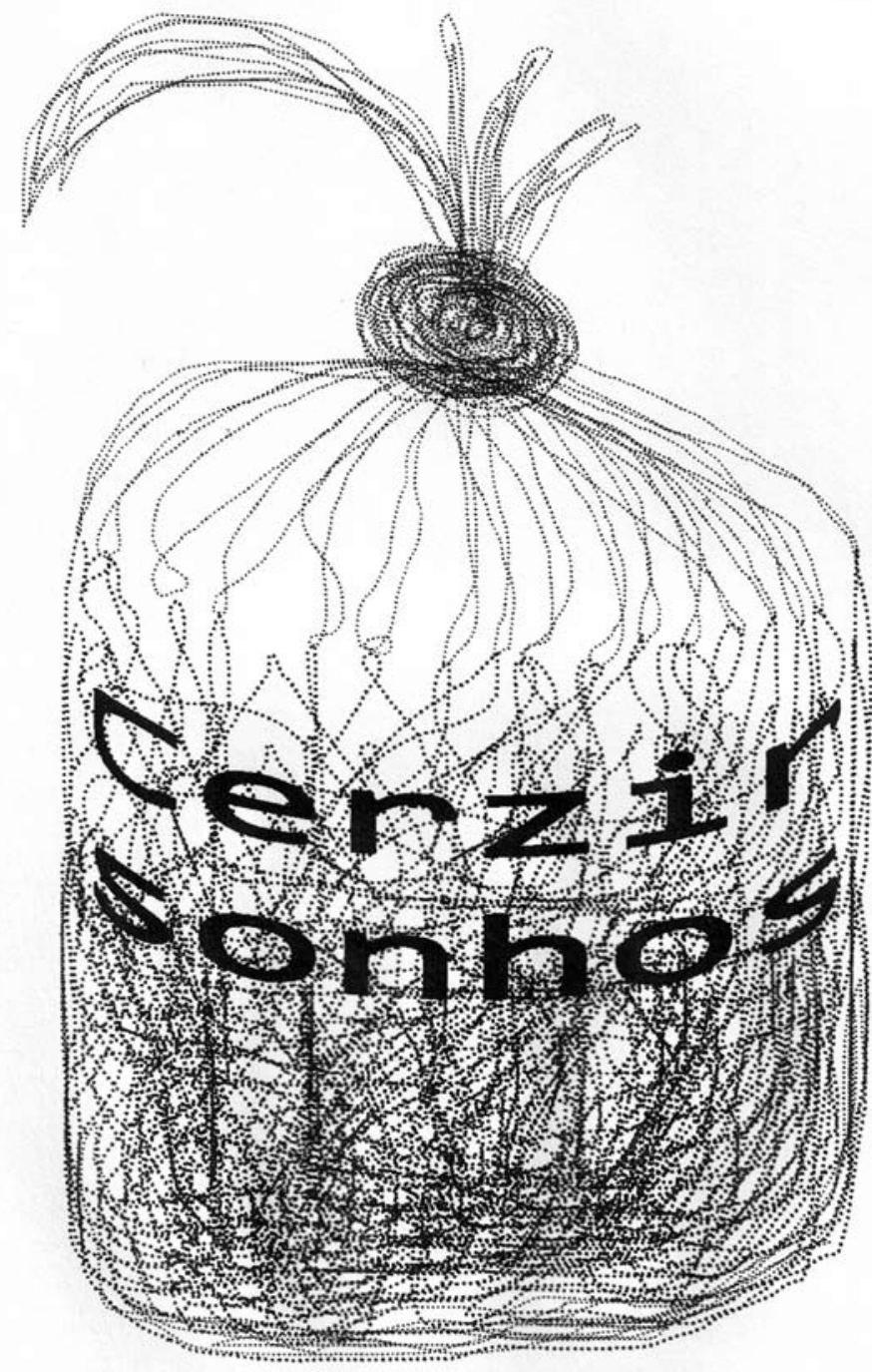




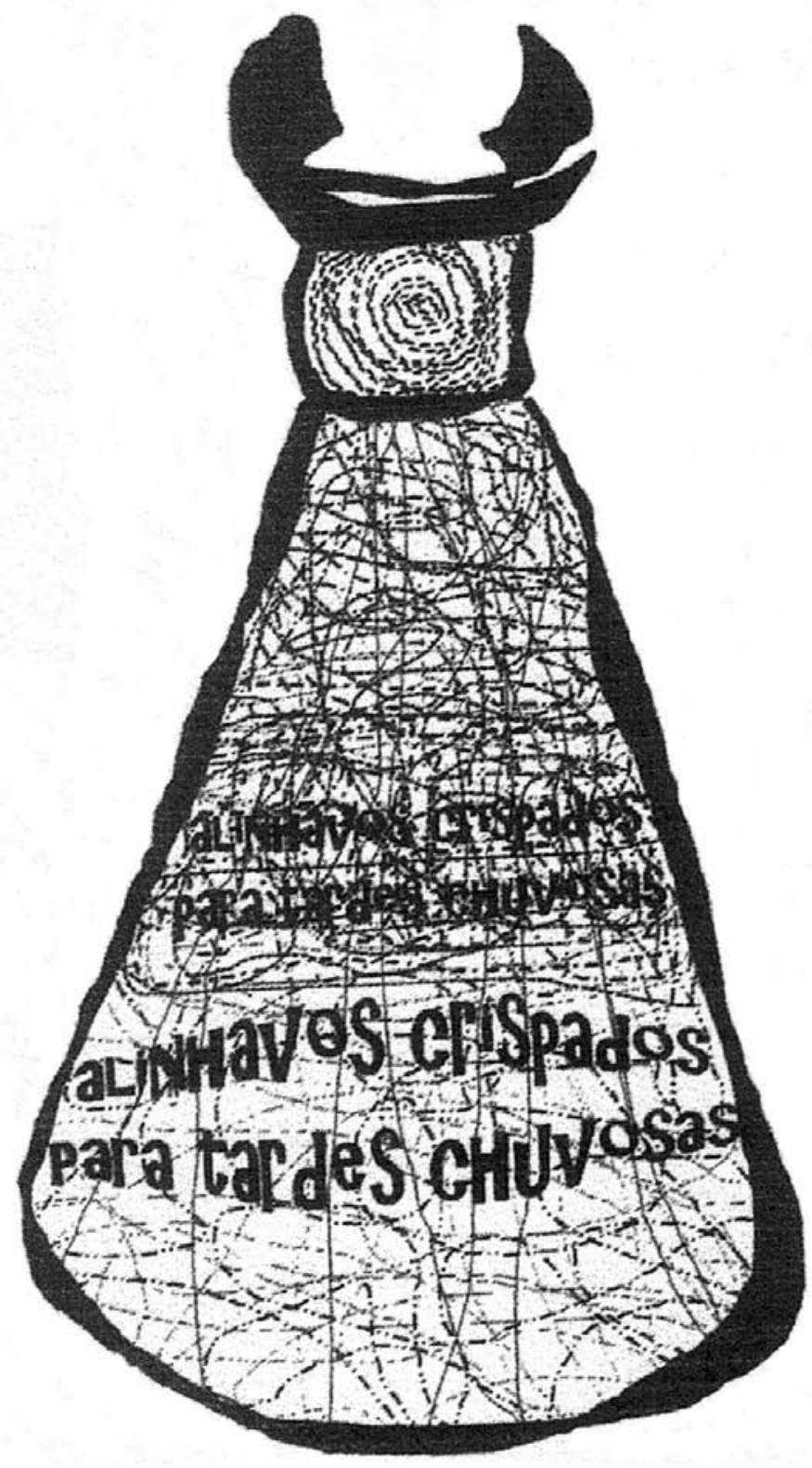




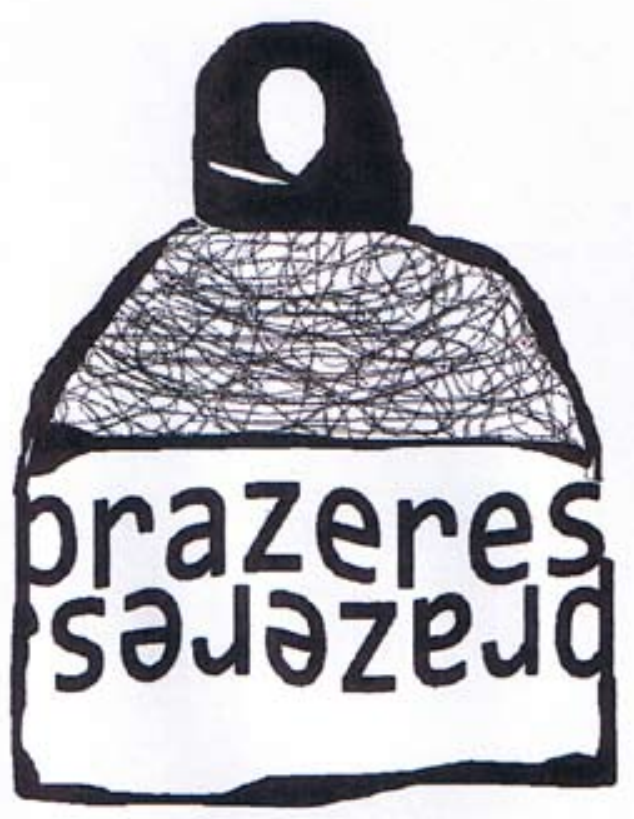




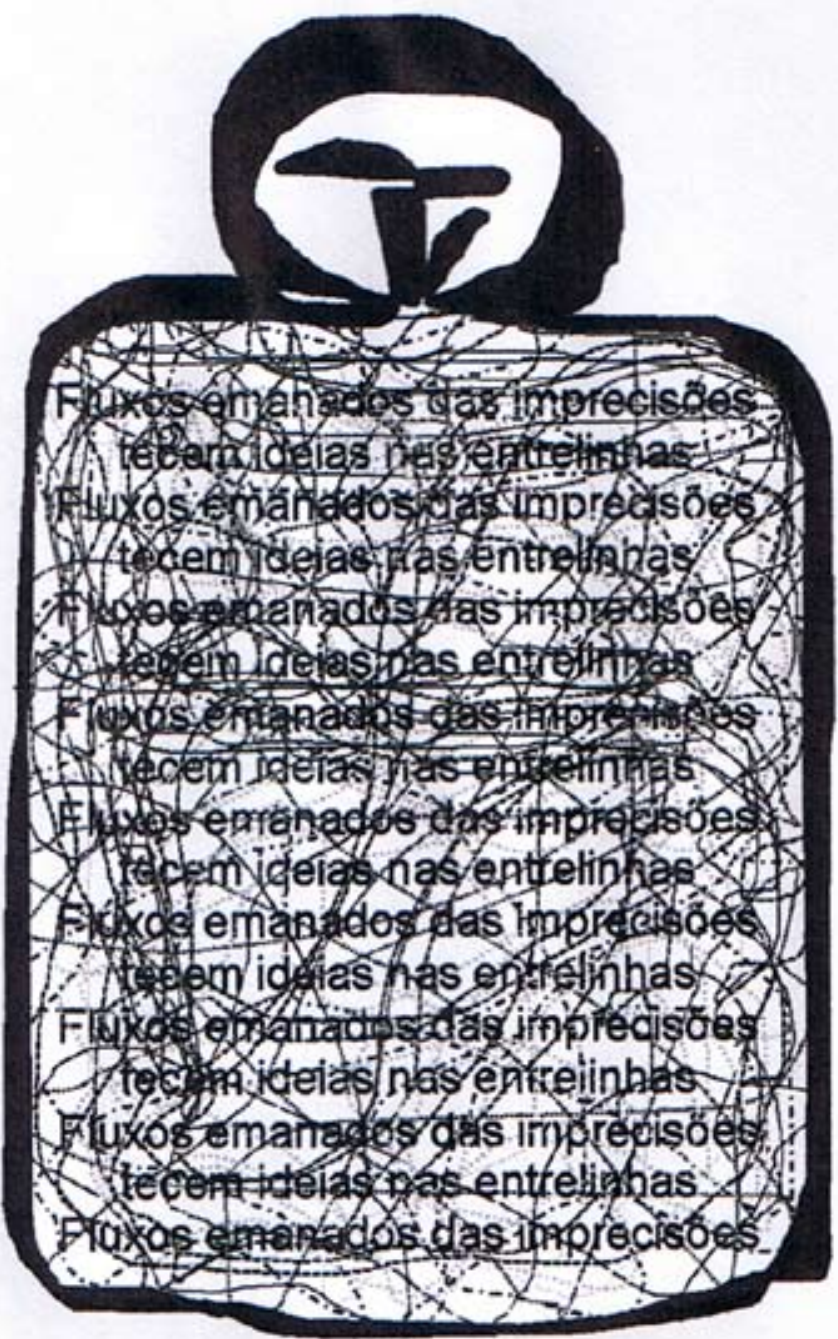




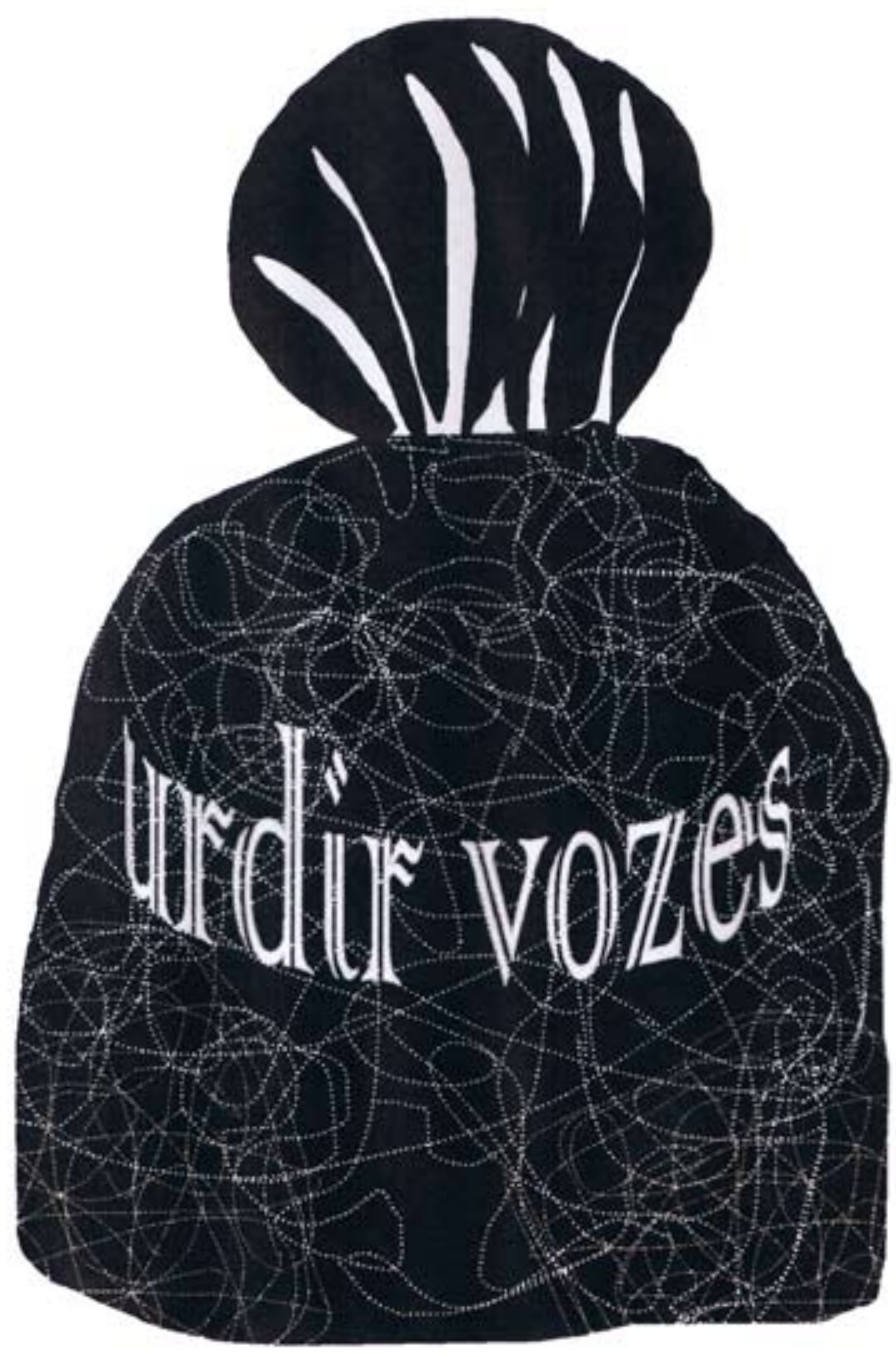




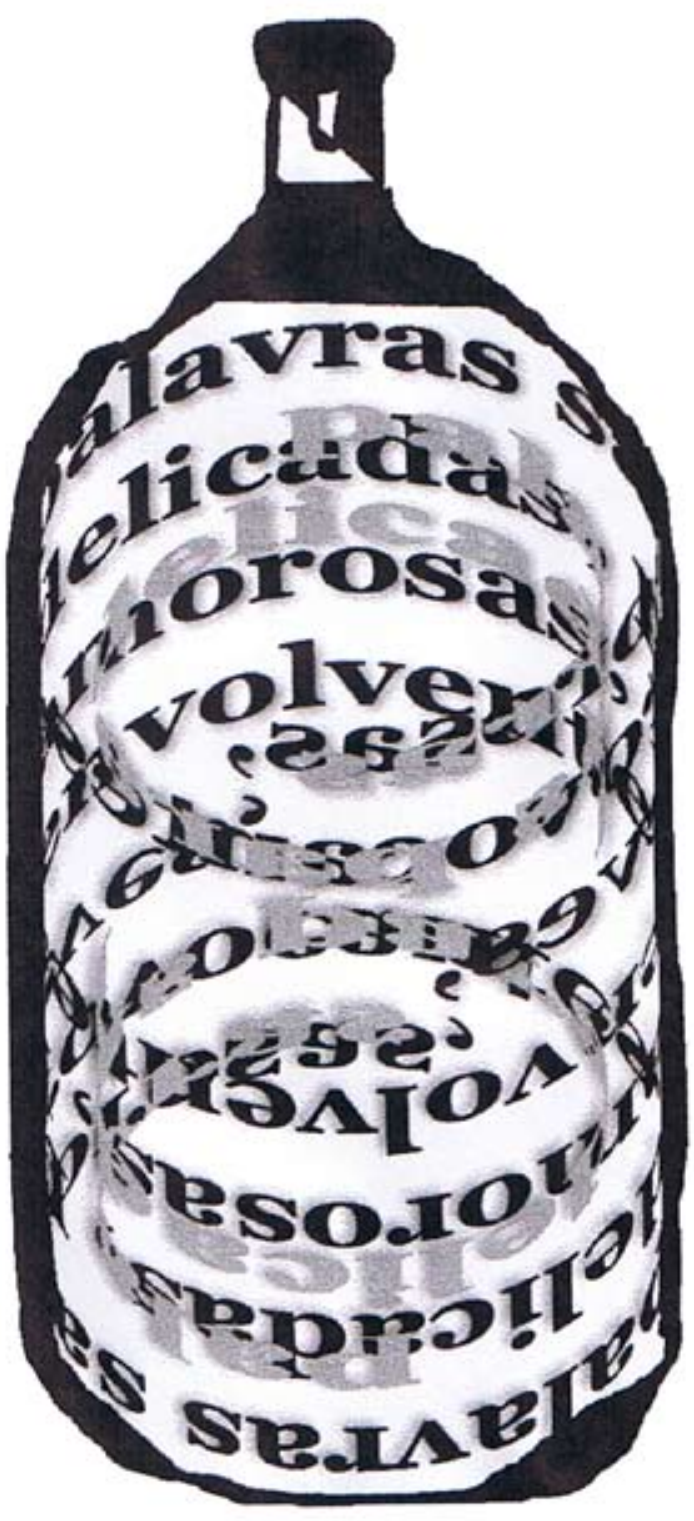




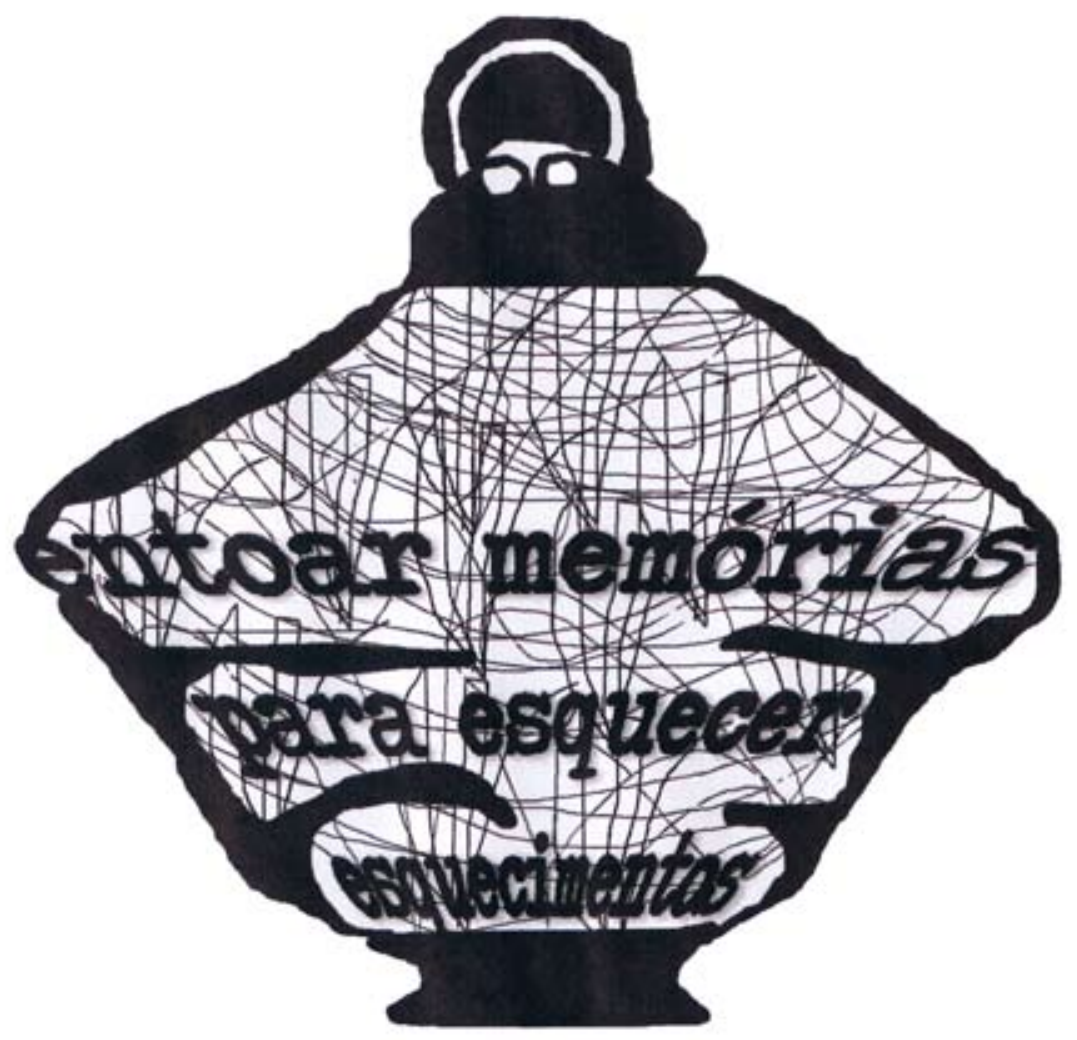




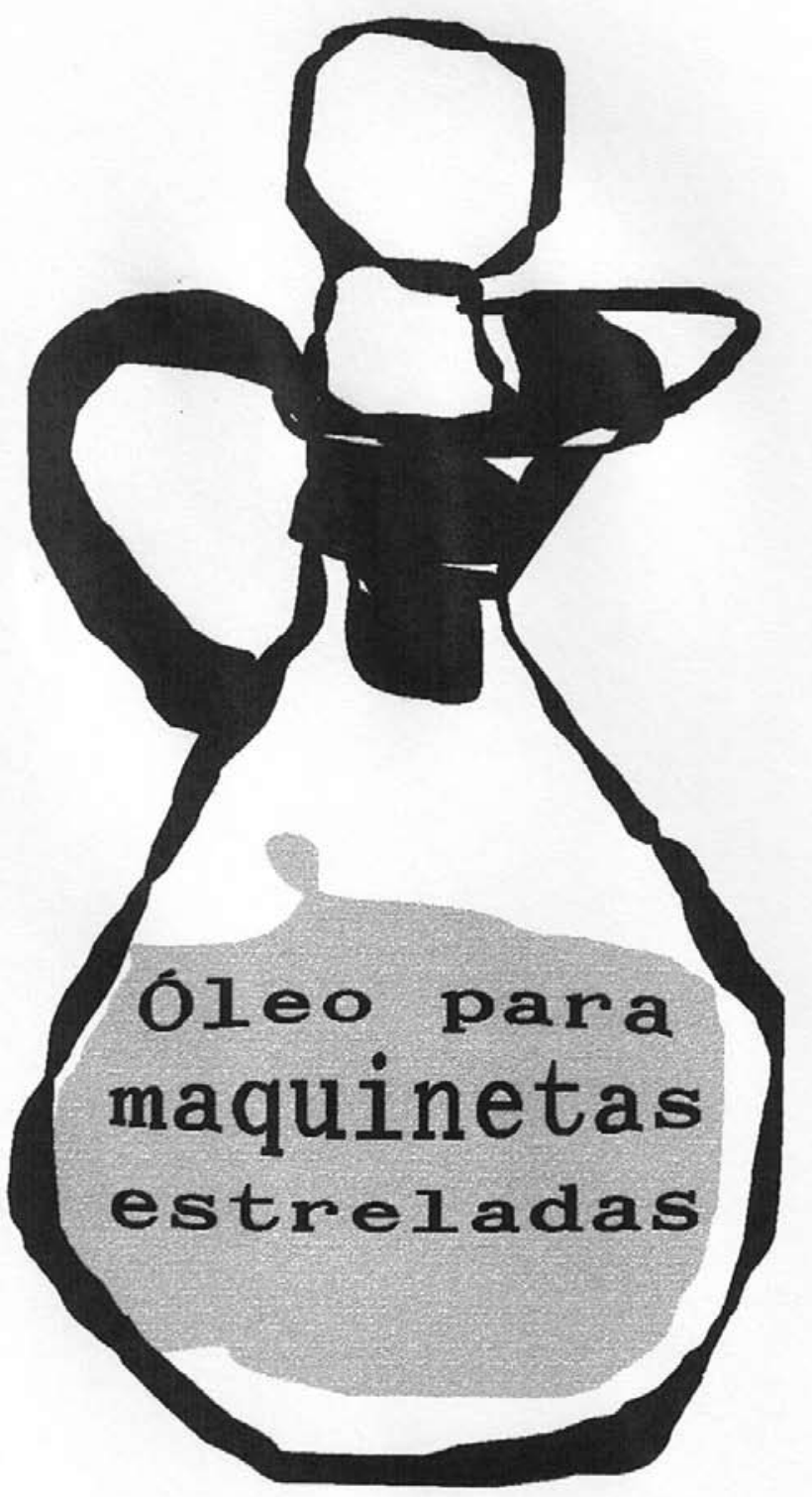




\section{entoar}

dormem em mim

palavras crispadas

desconheço-me,

nos dias de agora

respiro vogais,

entôo saberes

em nada brutais,

e docemente esqueço-me

de esquecer 


\section{Caminhos urbanos \\ Costuras poéticas}

"Não haverá nunca uma porta. Estás dentro

$E$ o alcácer abarca o universo

E não tem nem anverso nem reverso"

Jorge Luis Borges - Elogio da Sombra

Desenho caminhos urbanos, labirintos

construídos nos instantes, nas descobertas.

Revejo e relaciono a matéria gráfica do céu,

da cidade, nas linhas, nas palavras.

Sensível à magia da natureza desenho

nuvem, matéria incisiva e flutuante, densa e

leve, clara e escura, mutante, invenção tempo-

atmosfera nos desenhos impregnados de imagens textuais, num envolvimento citadino.

Tempo e espaço se fundem numa intensa

costura, apresento cidades onde poesia é conversa com o mundo. 



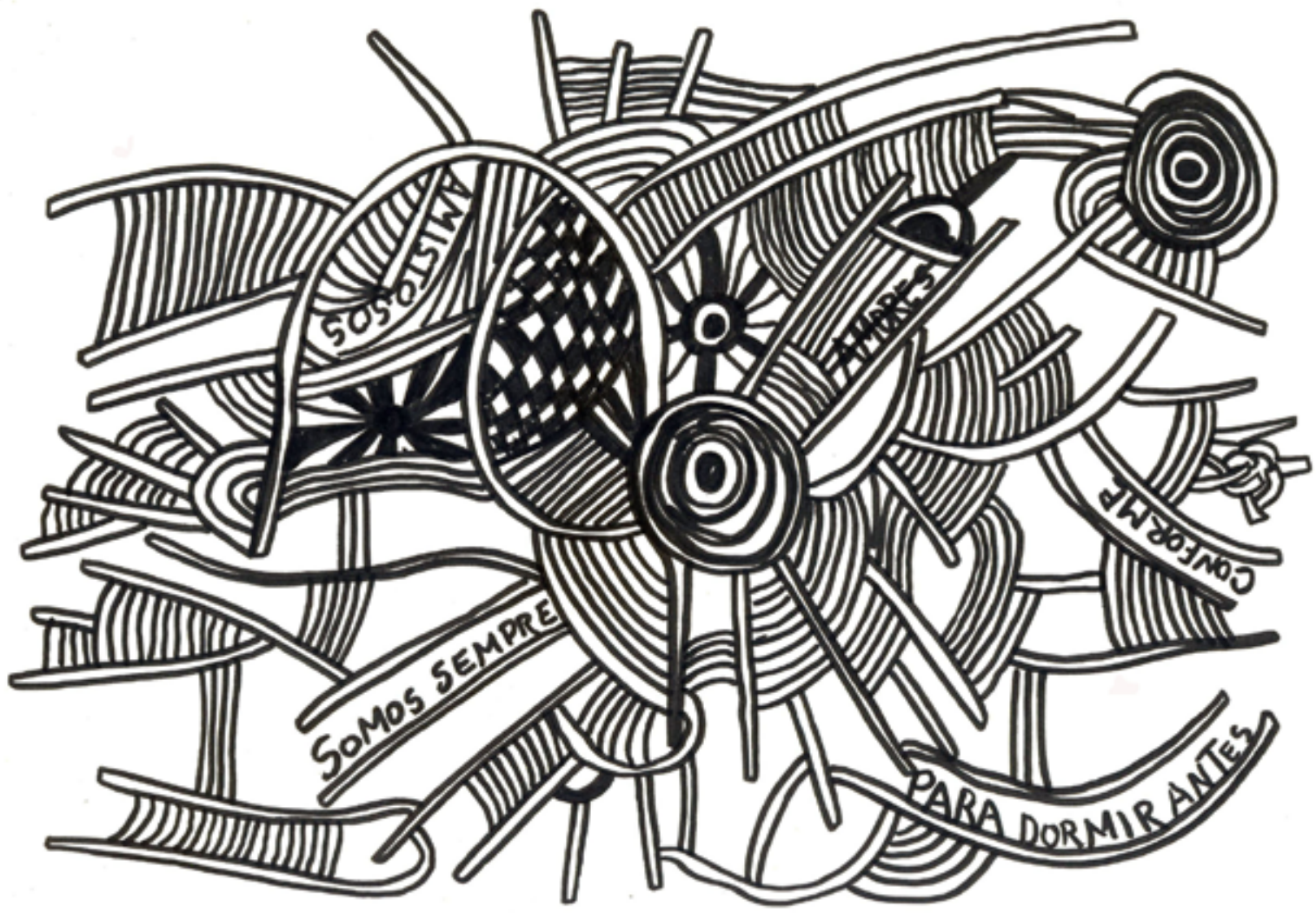




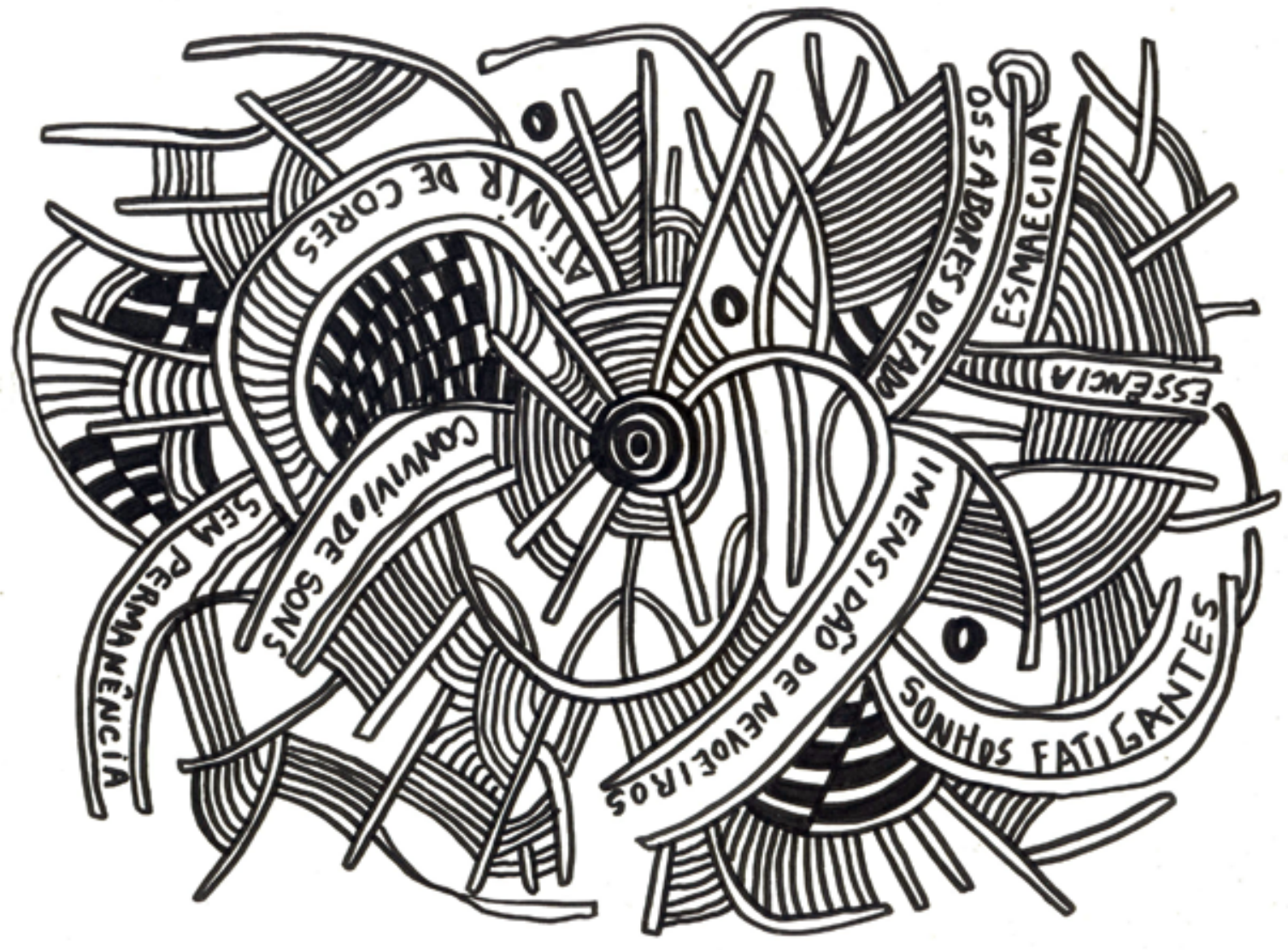




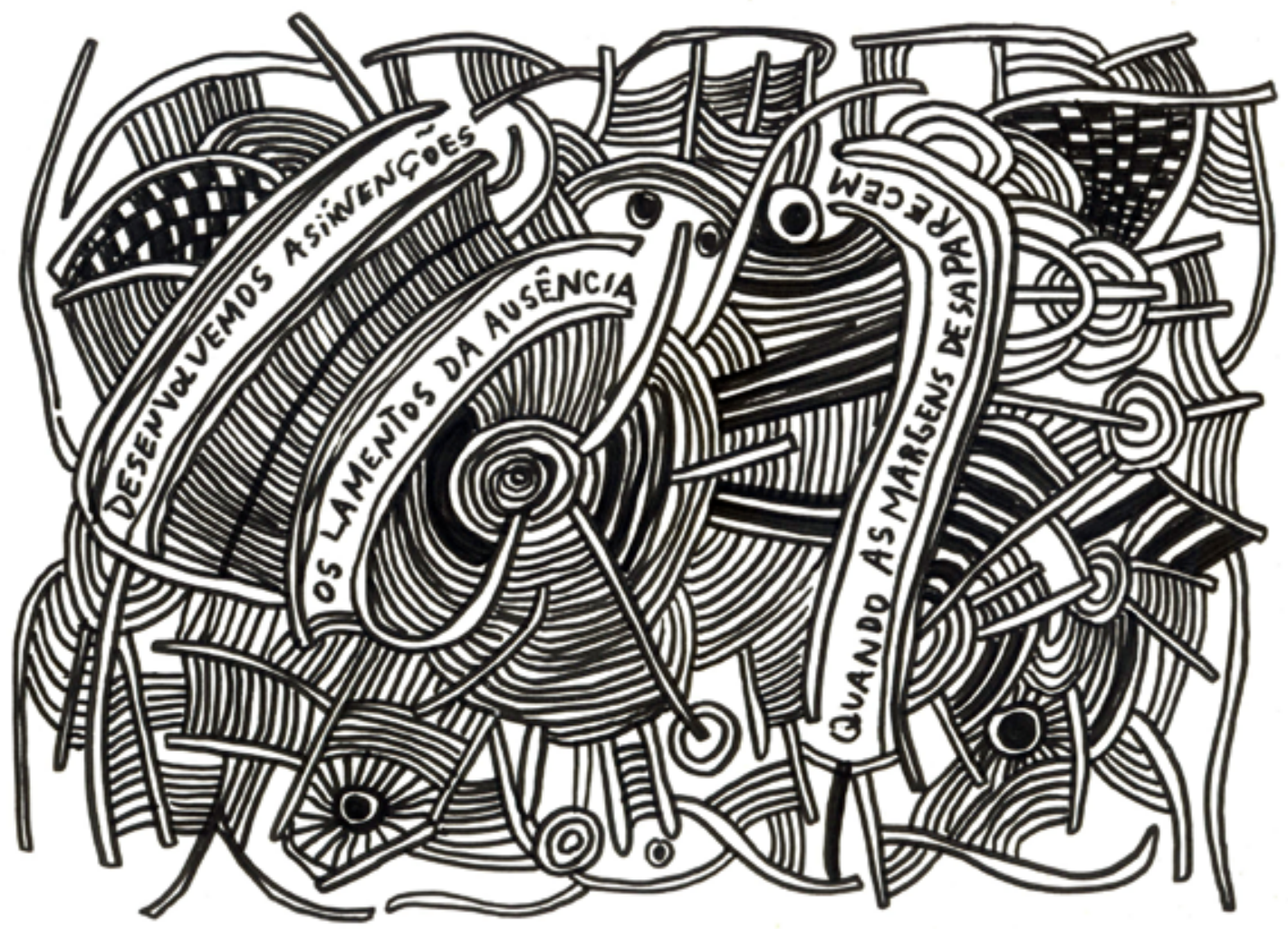




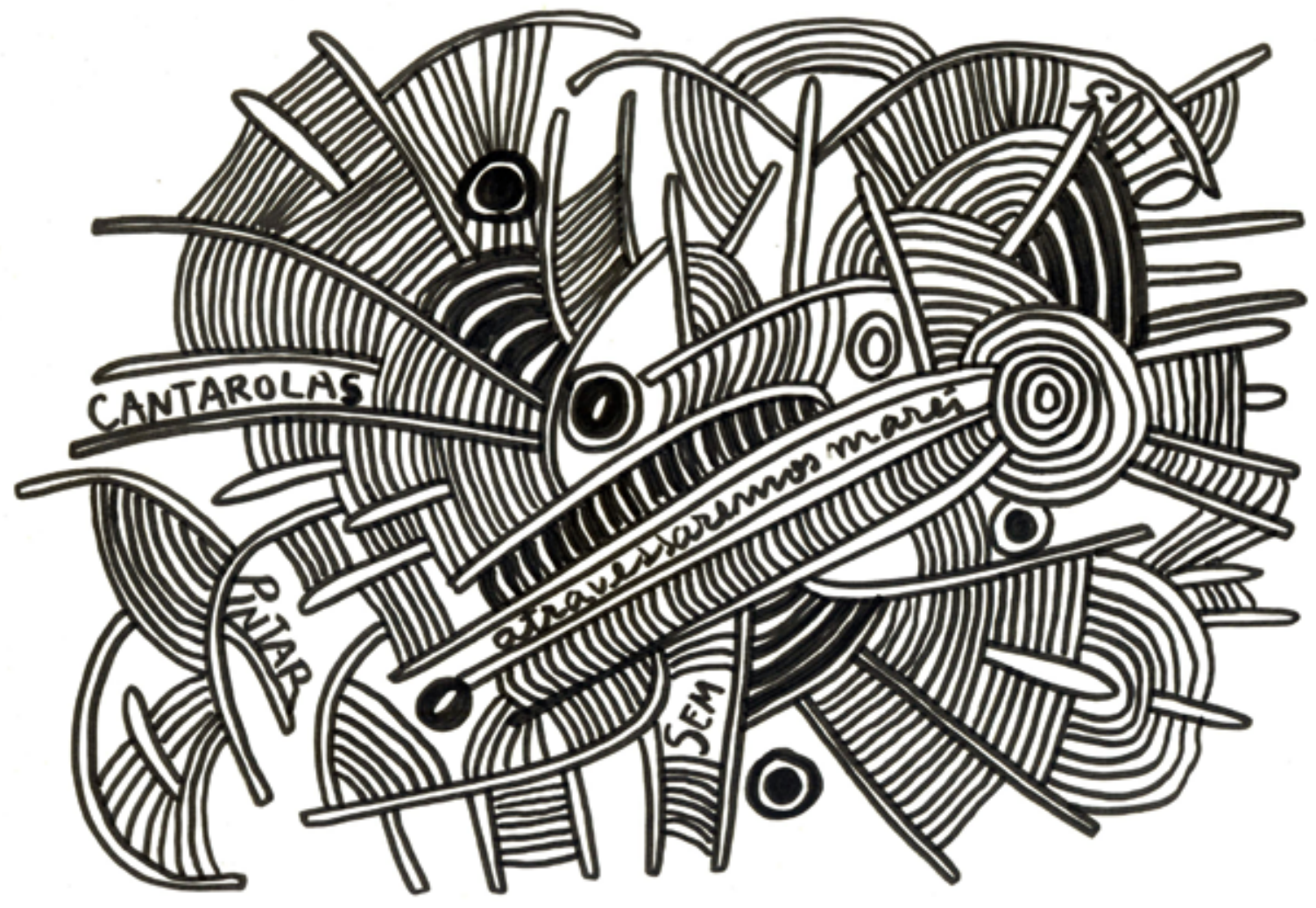




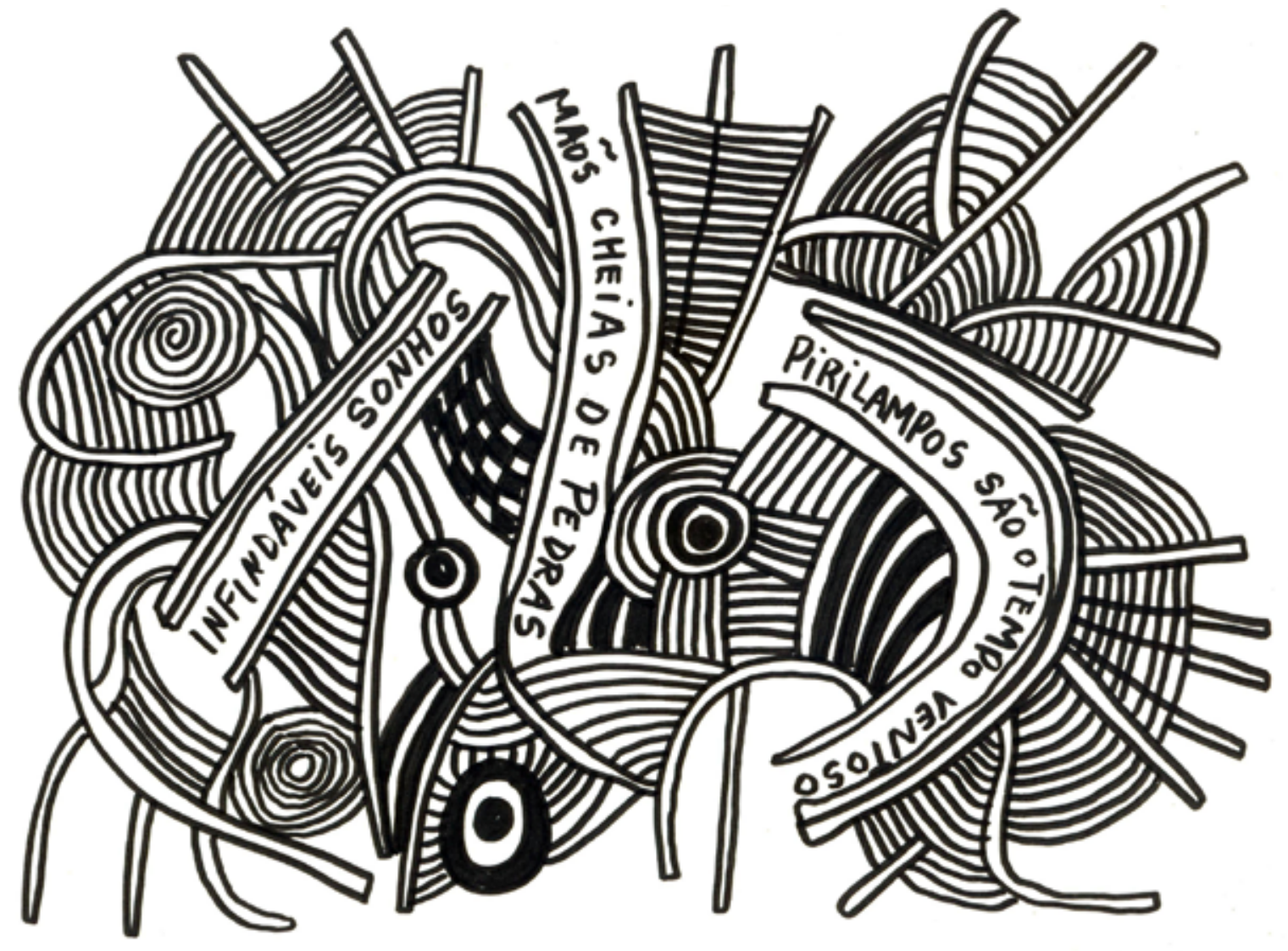




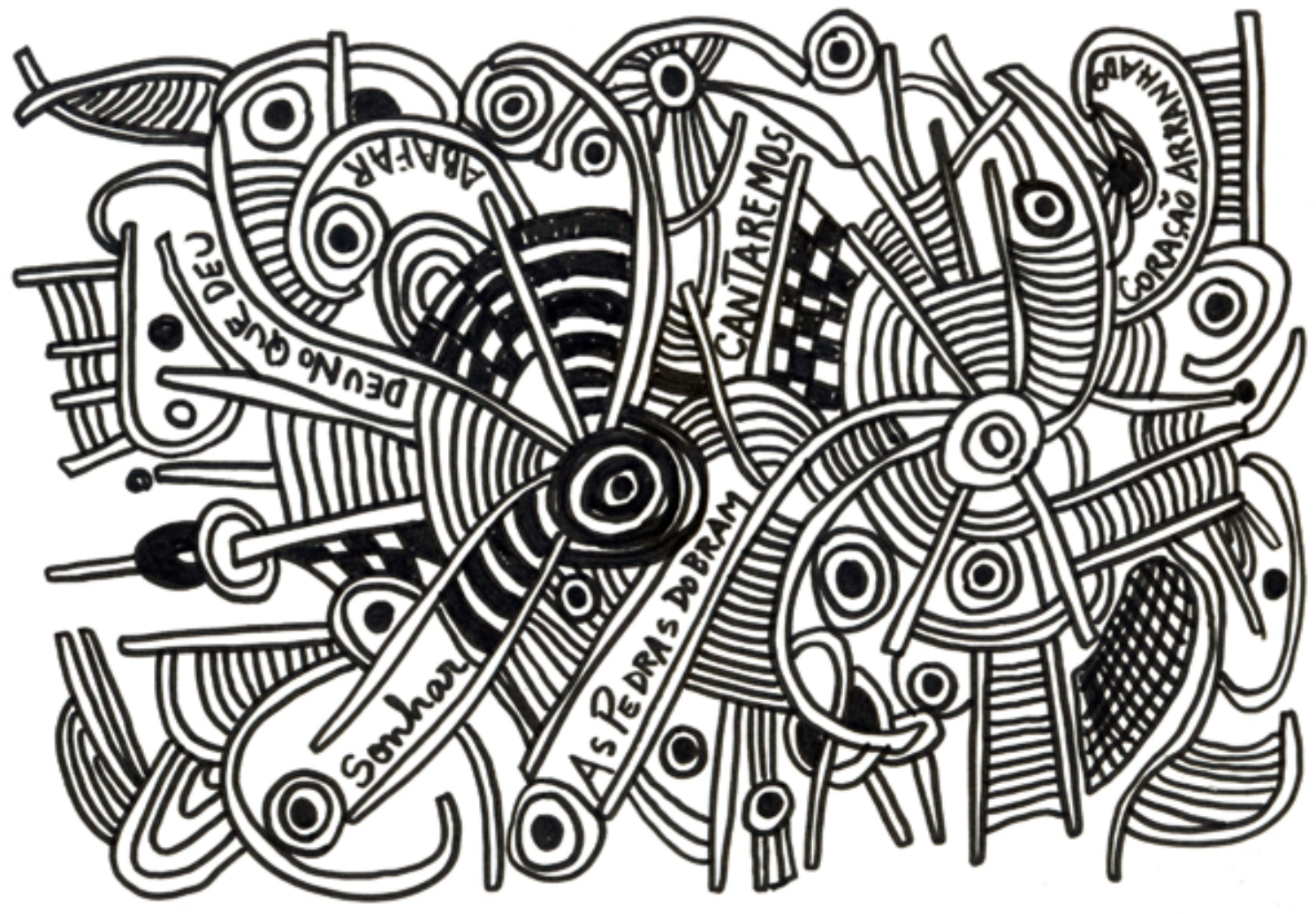




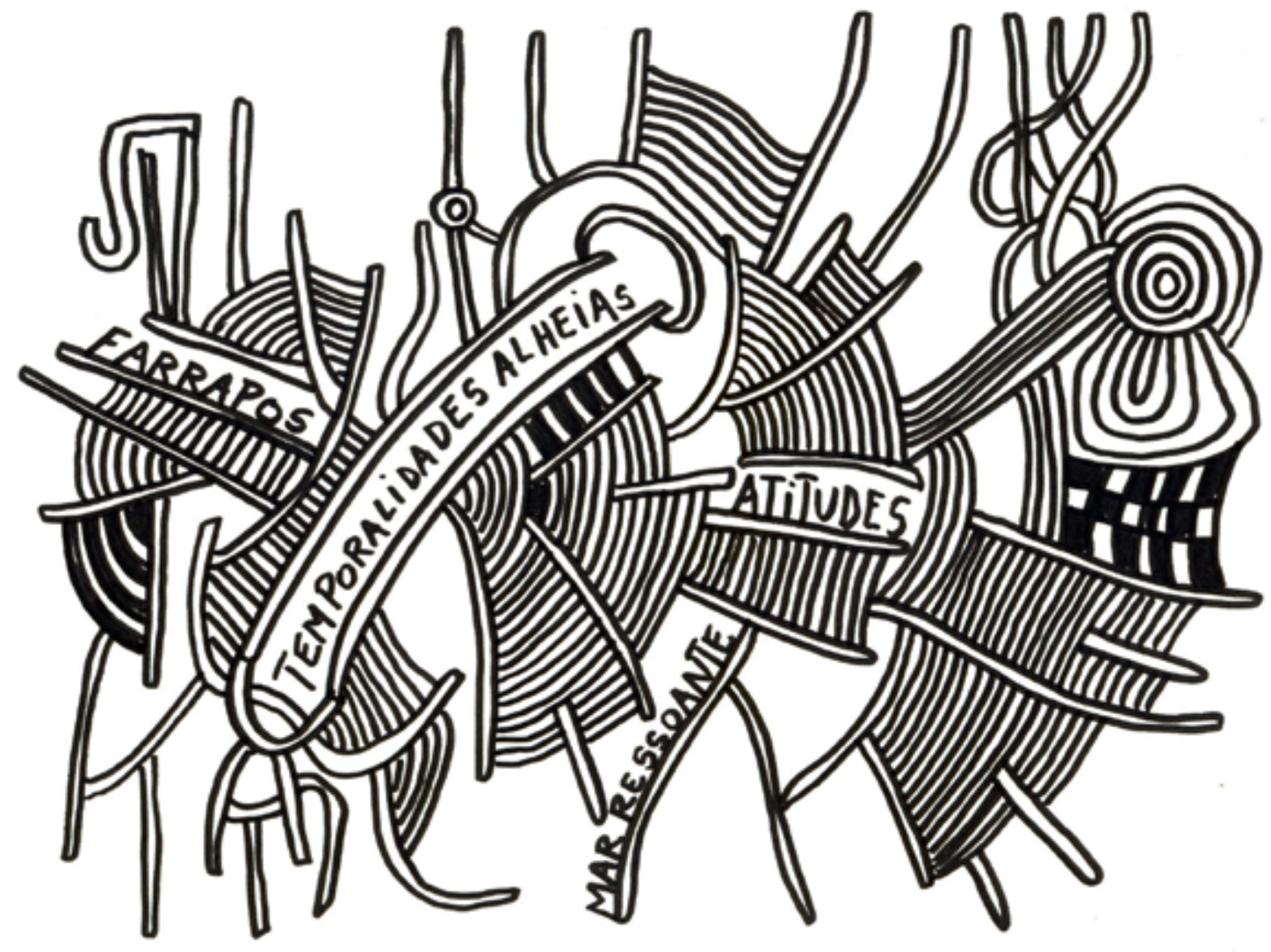




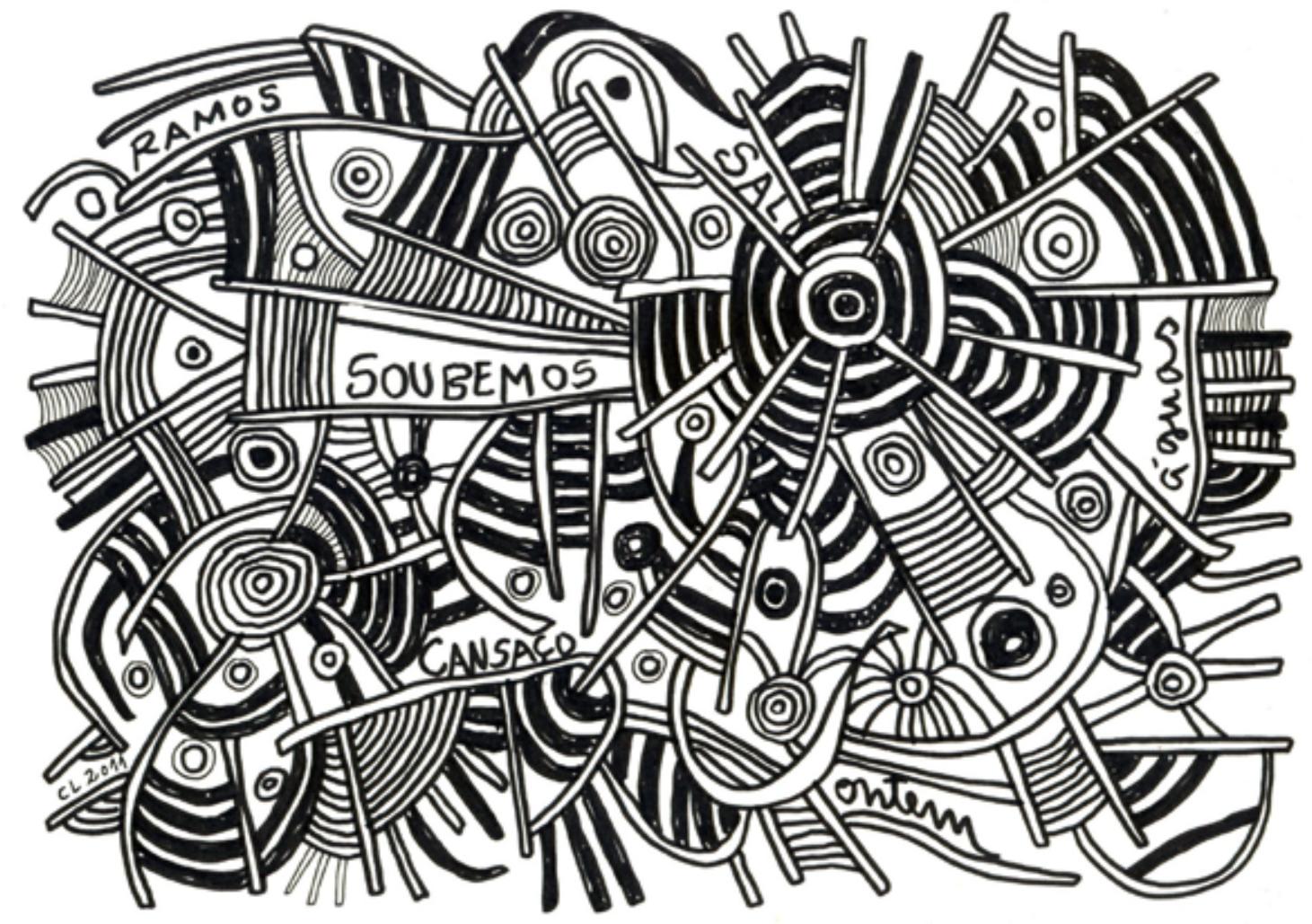




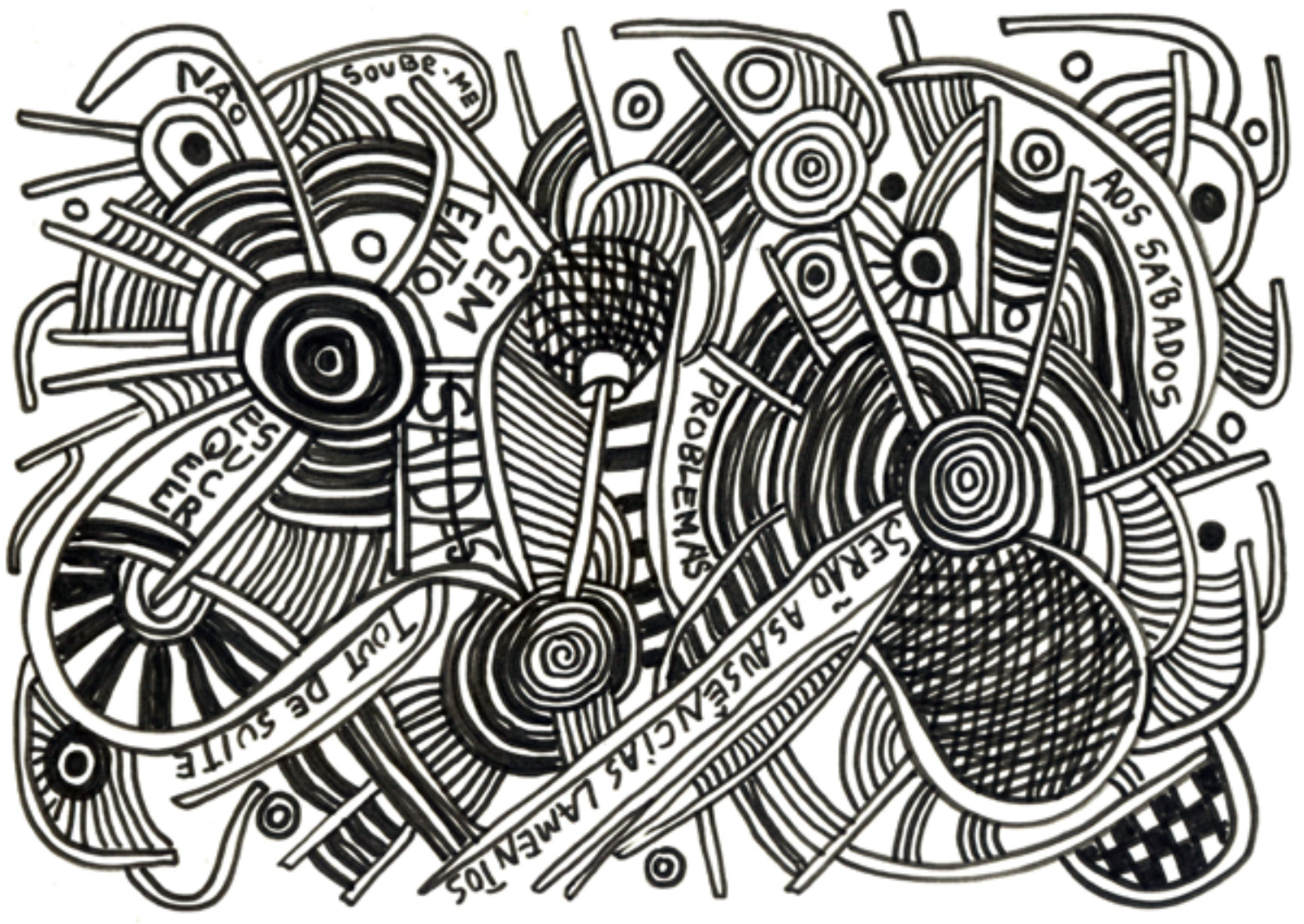




\section{De quando em vez}

"Oh vem silêncio serenado e oculto

De um recordar que a vida só repete

Se a repetimos de memória antiga! "

Jorge de Sena - Exorcismos 


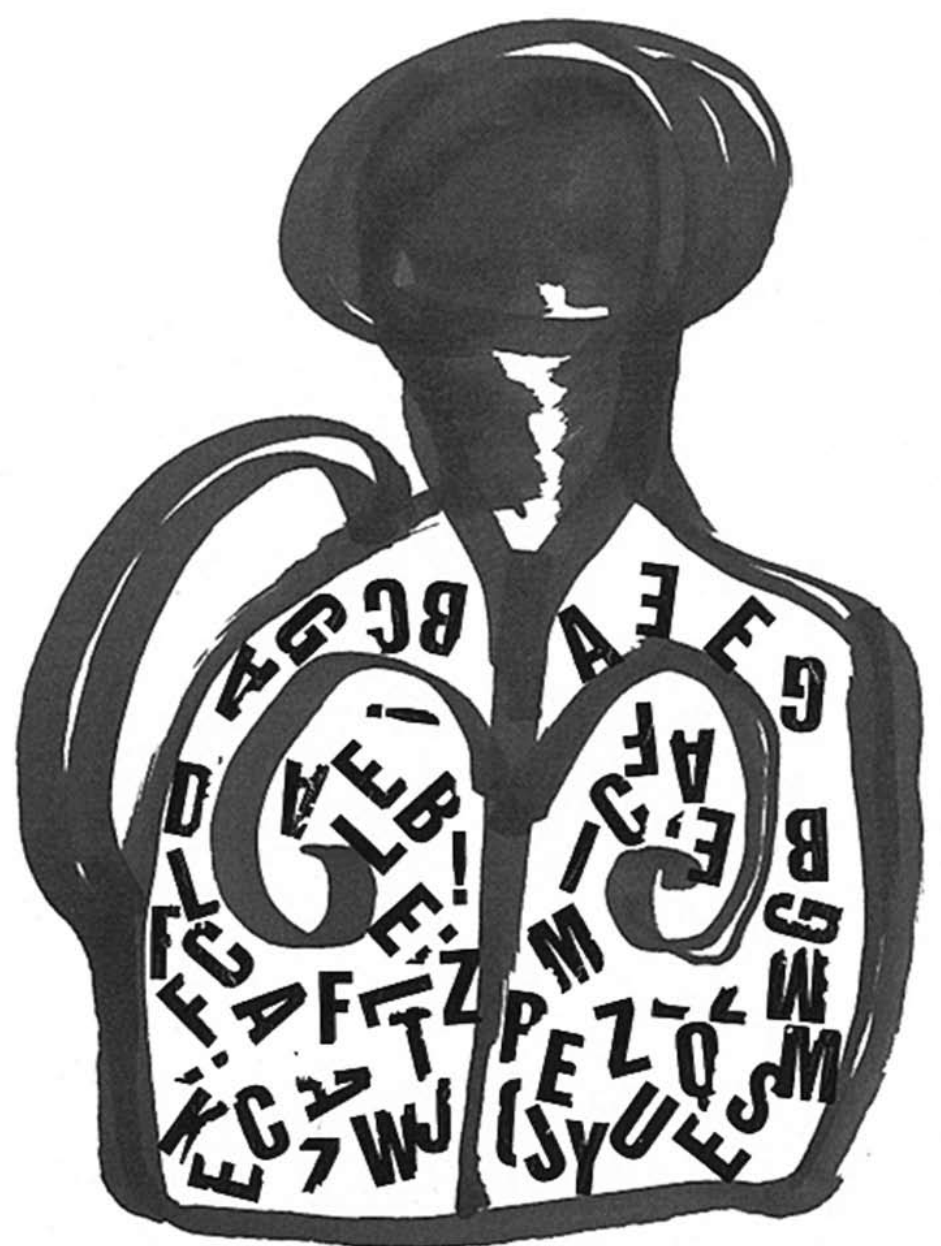




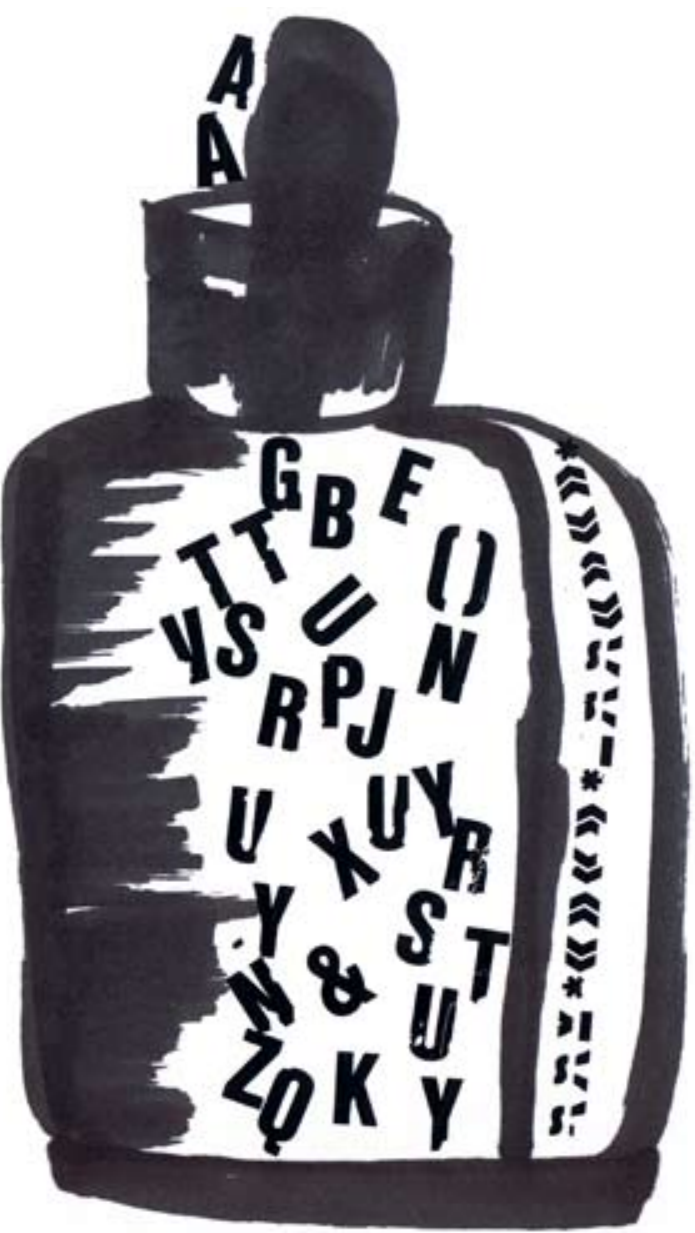




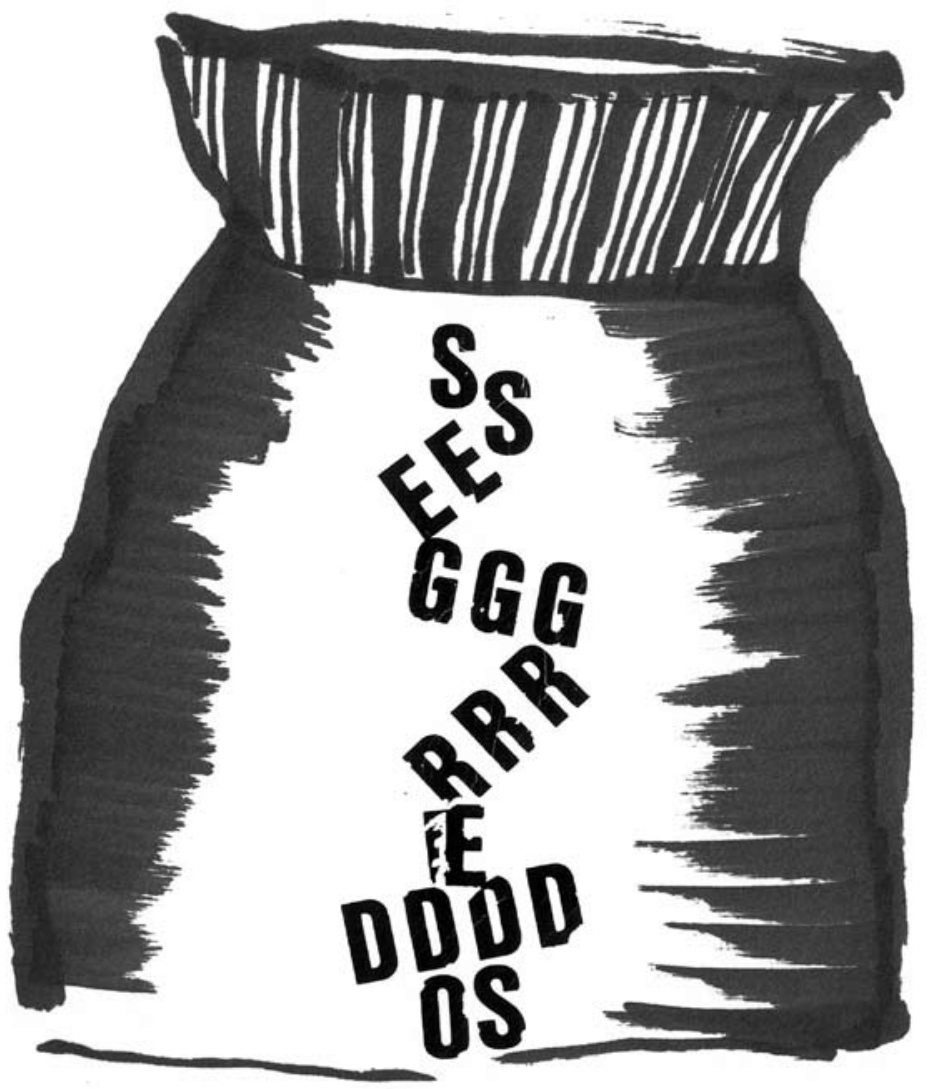




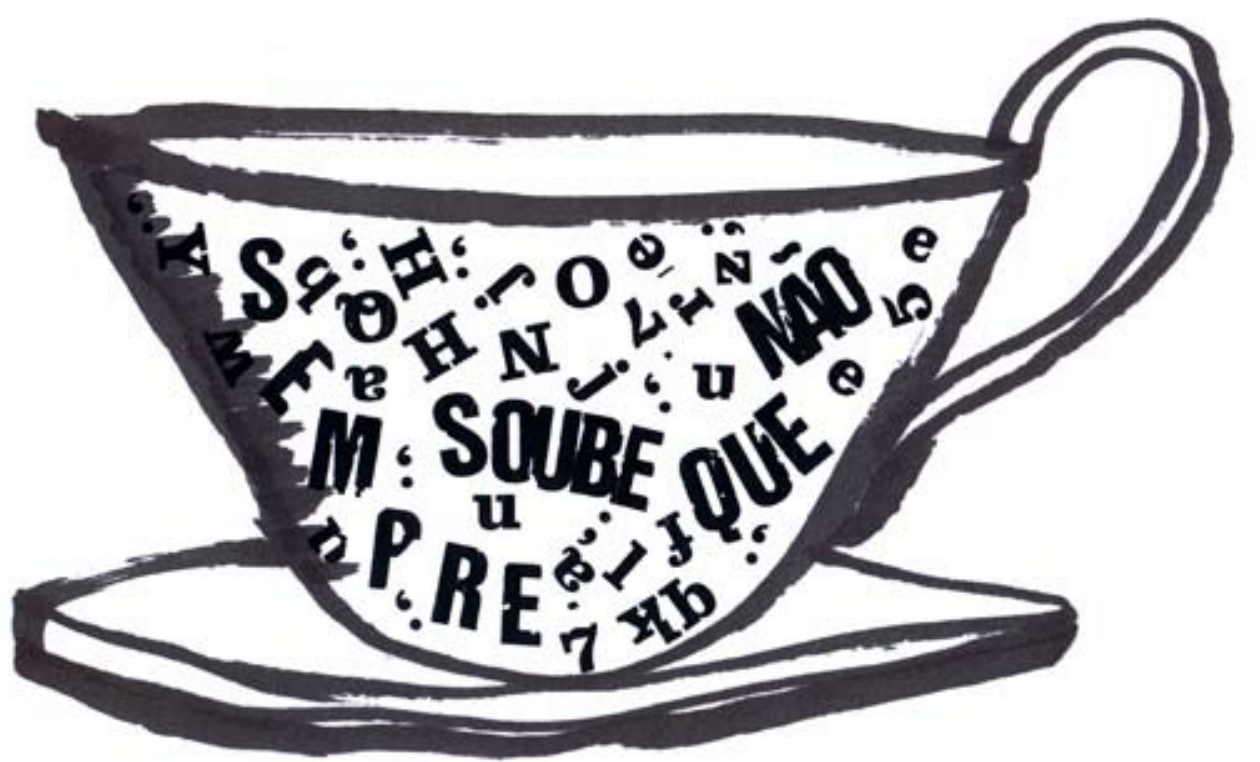




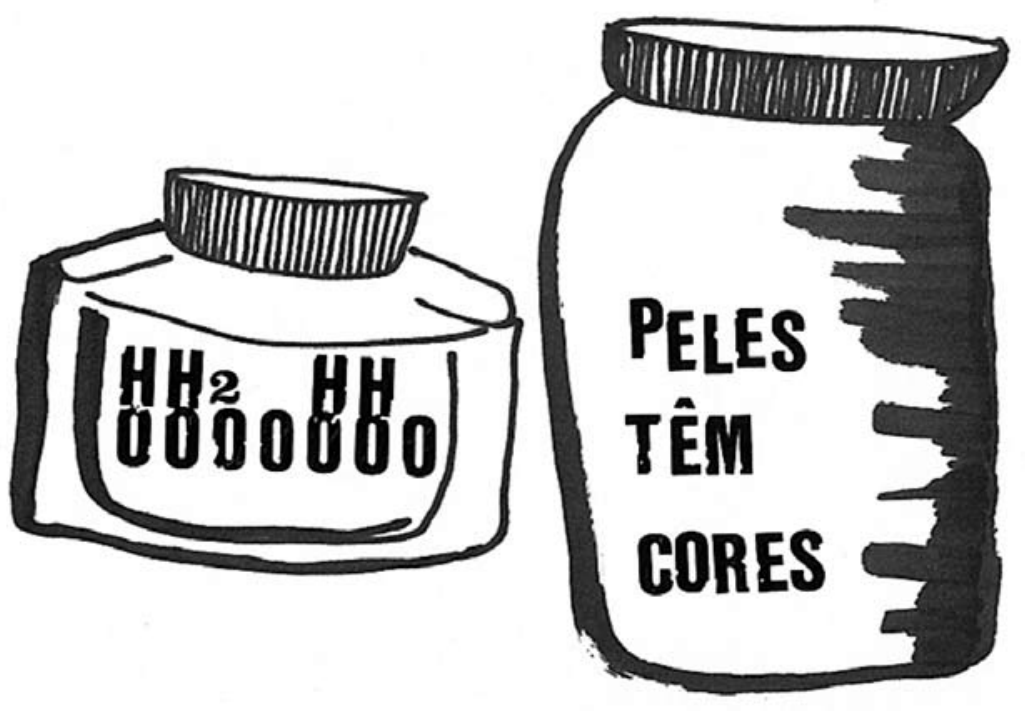




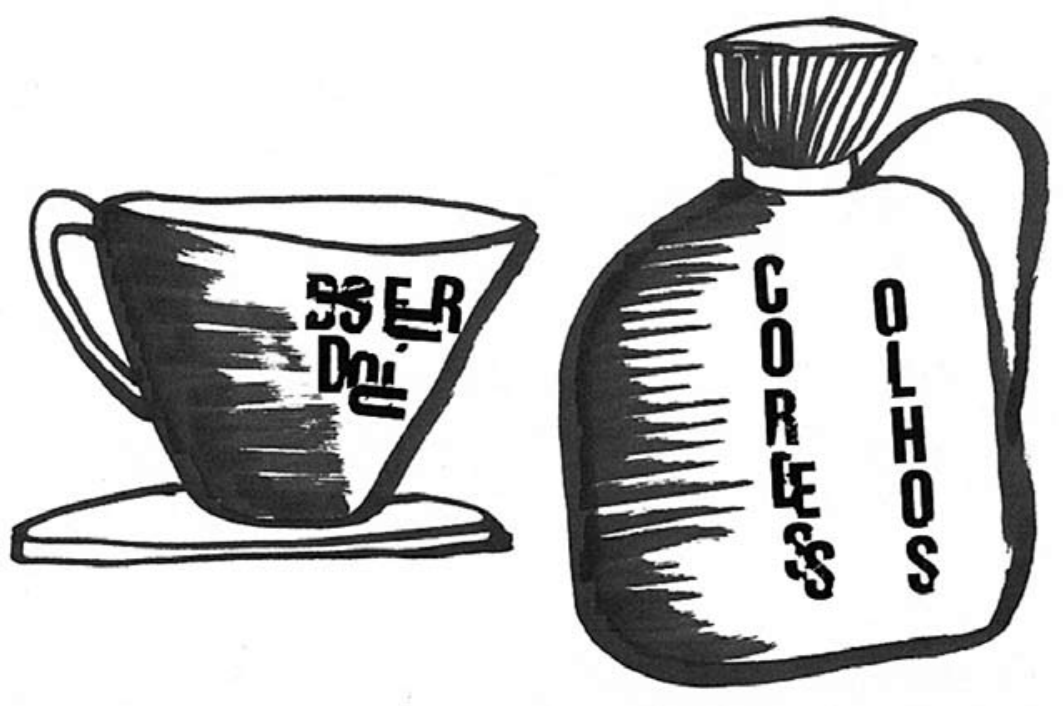




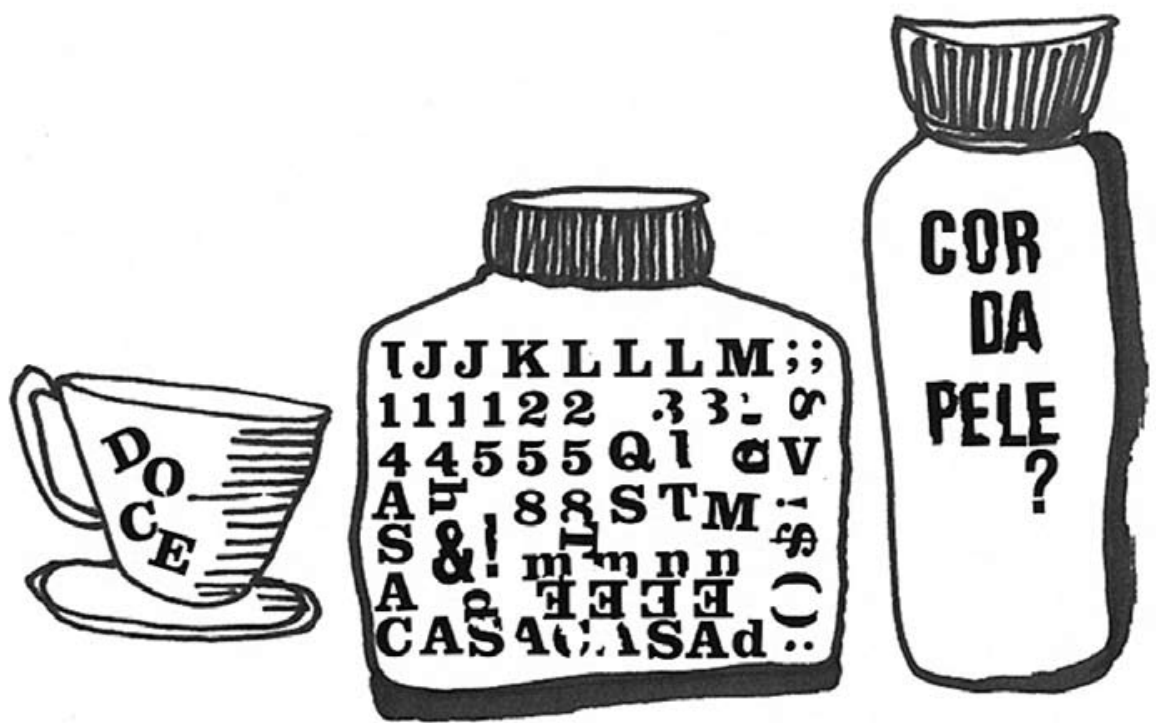




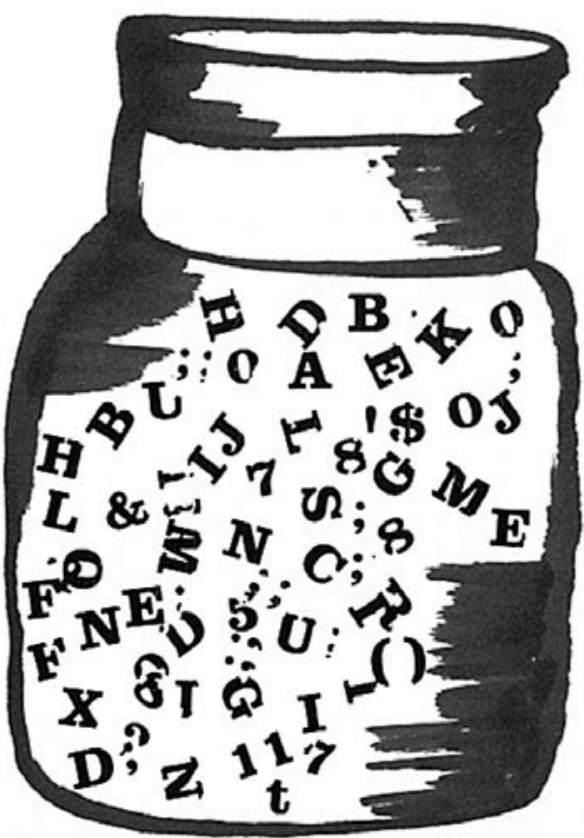



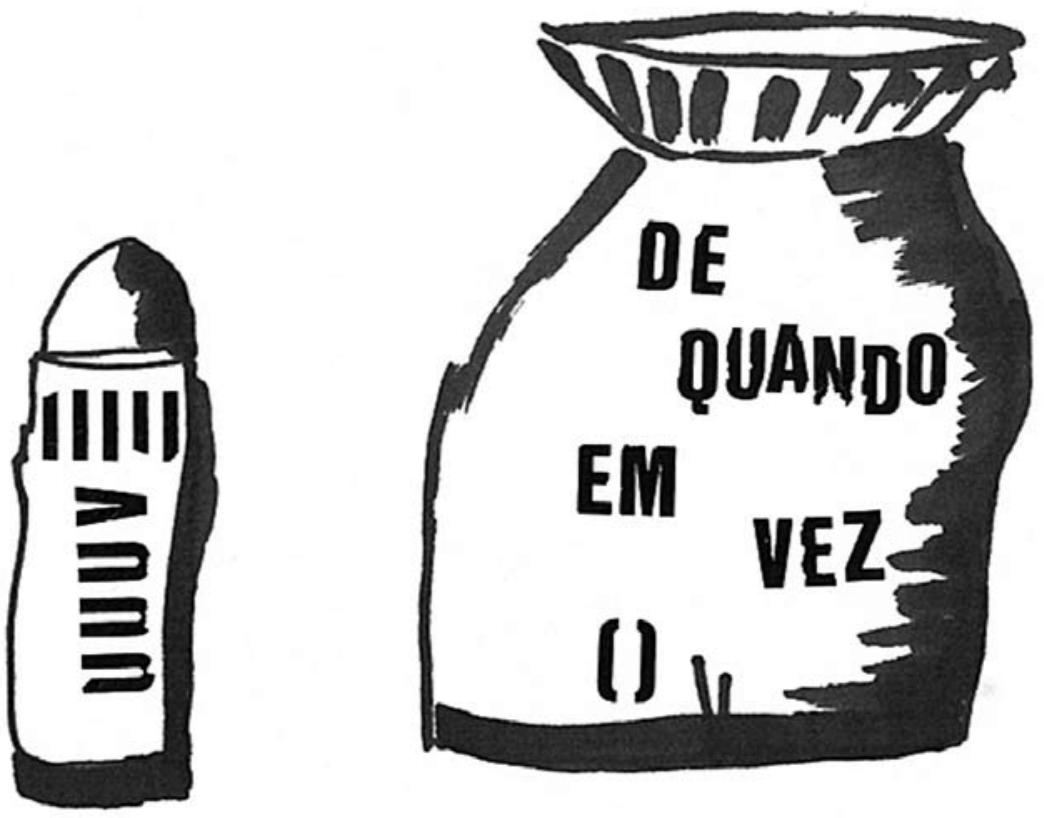
As palavras mudam as batidas do coração a cada instante, desenho palavras sobre memórias

no tempo e espaço, que se fundem.

Navego pelo tempo no ato de desenhar.

0 desenho foi desde sempre um bom lugar para se viver. 
Alinhavar sonhos

Vivenciar espaços onde os sonhos

projetam-se nos desenhos 


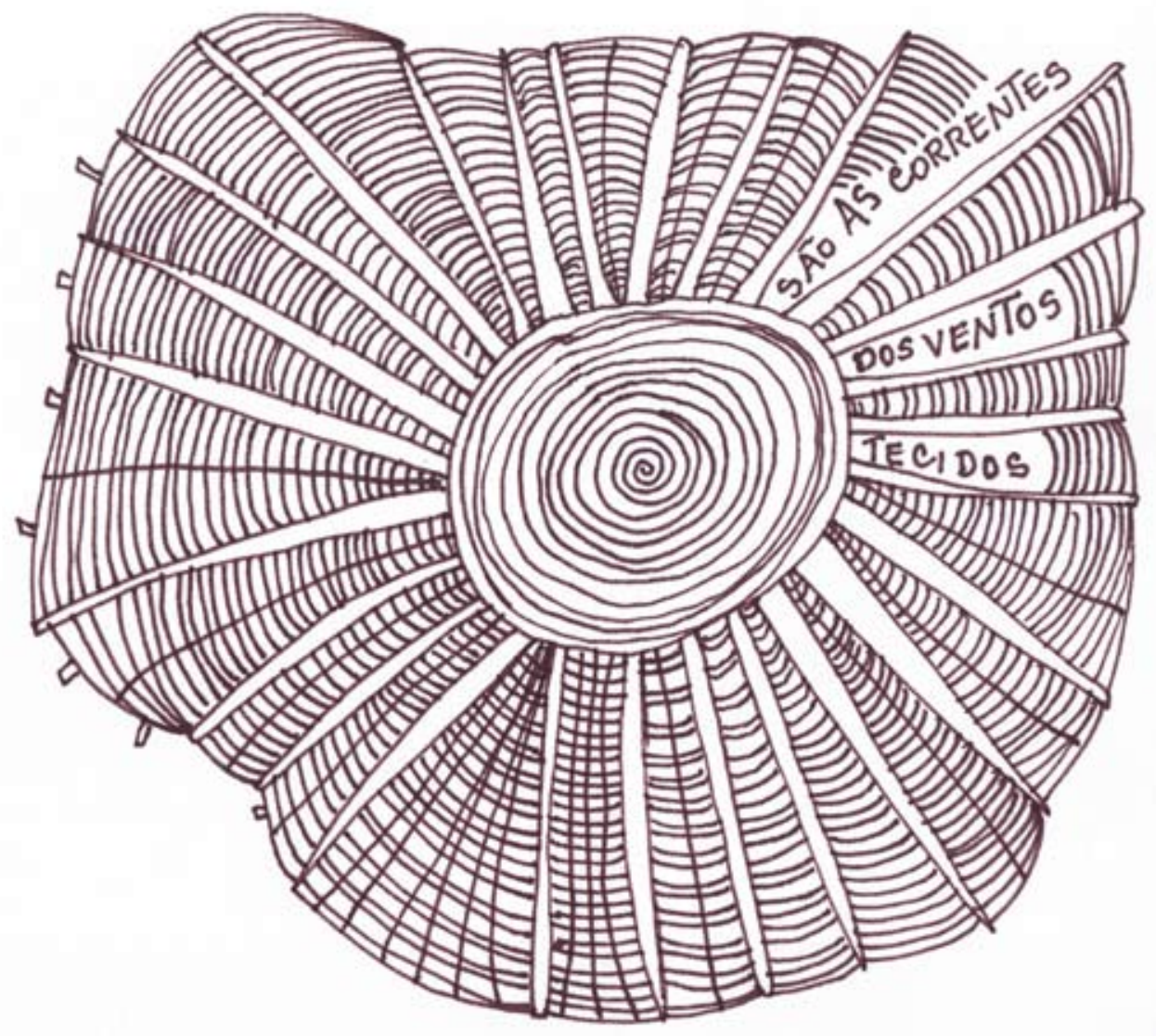




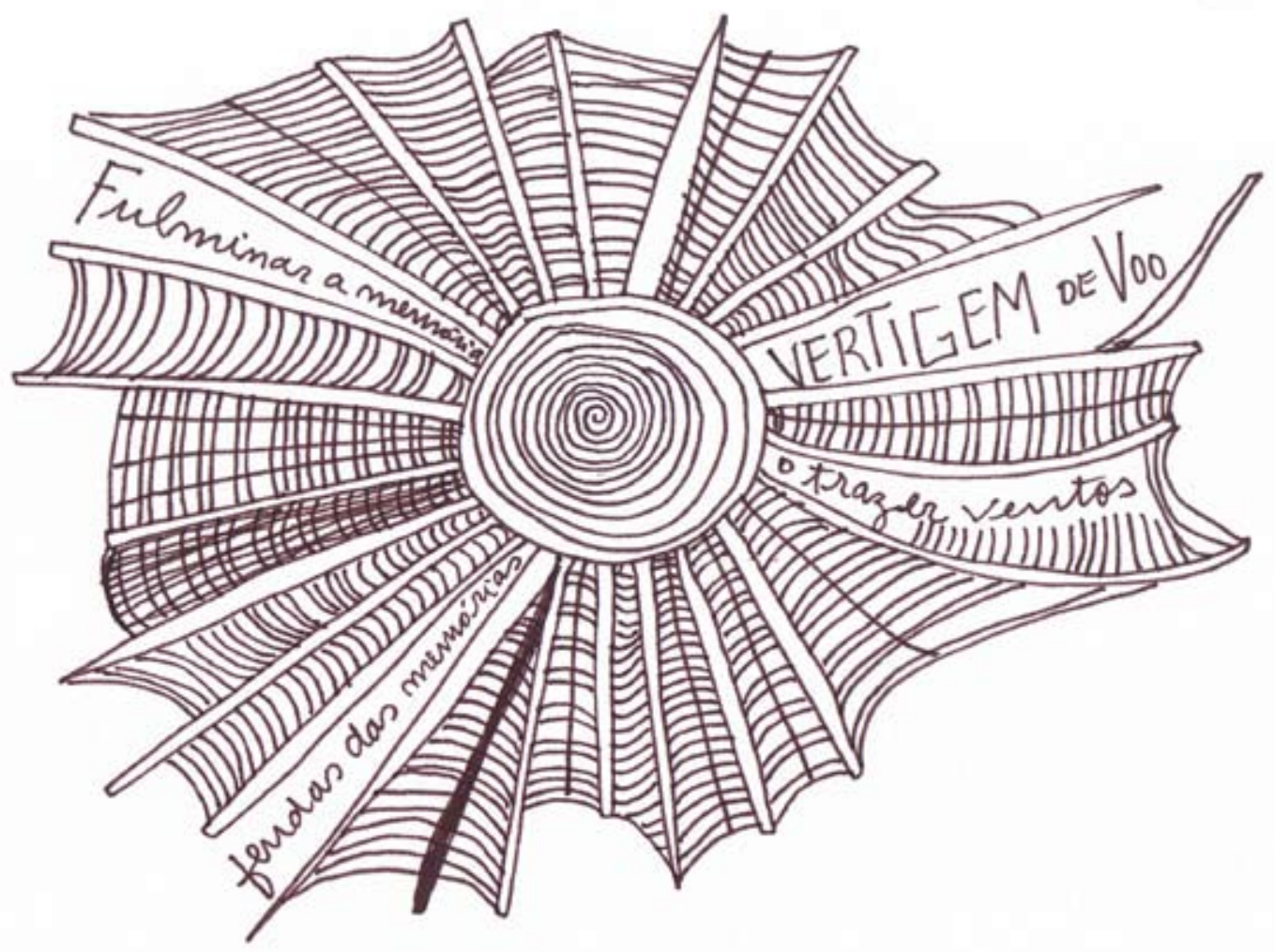




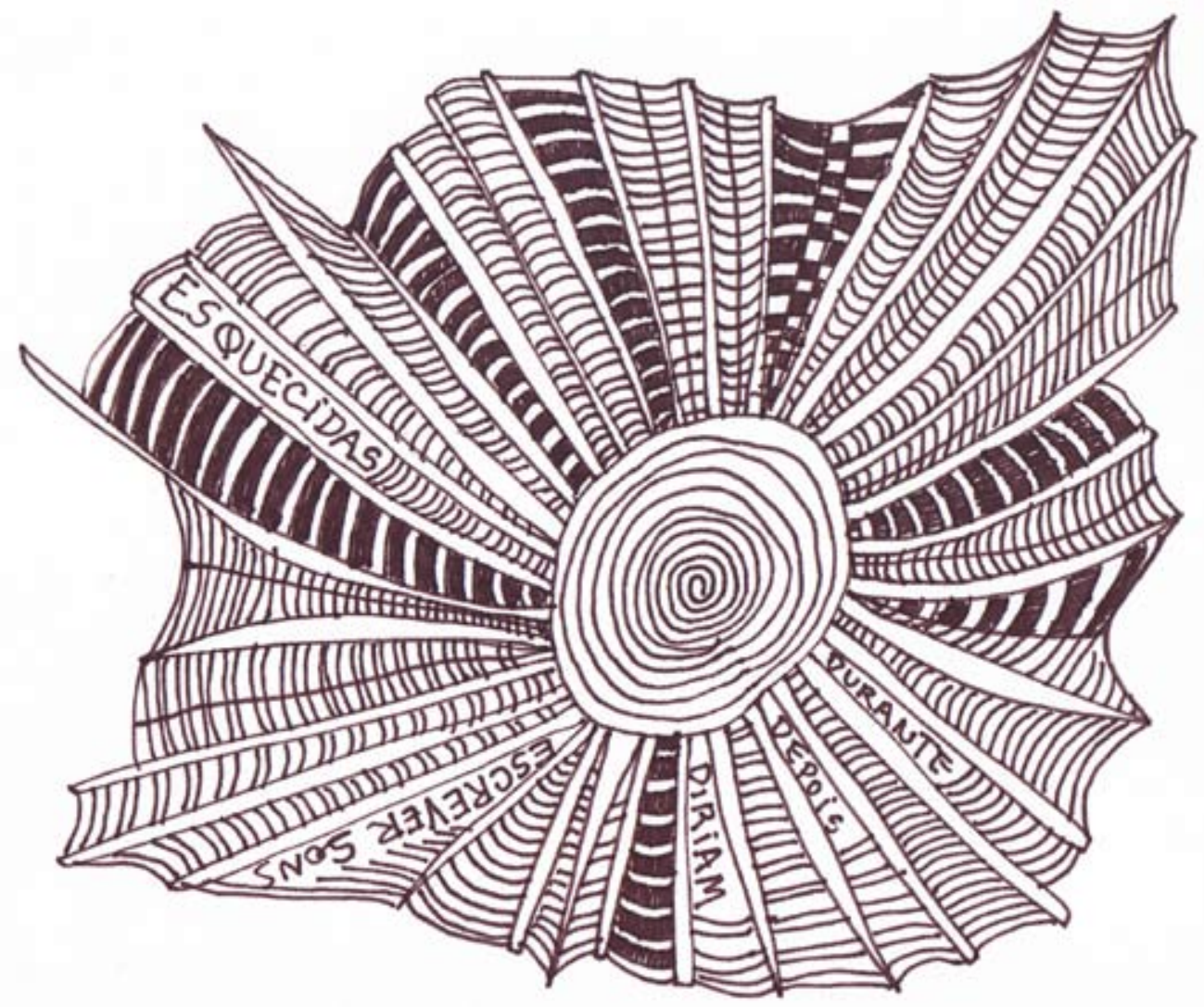




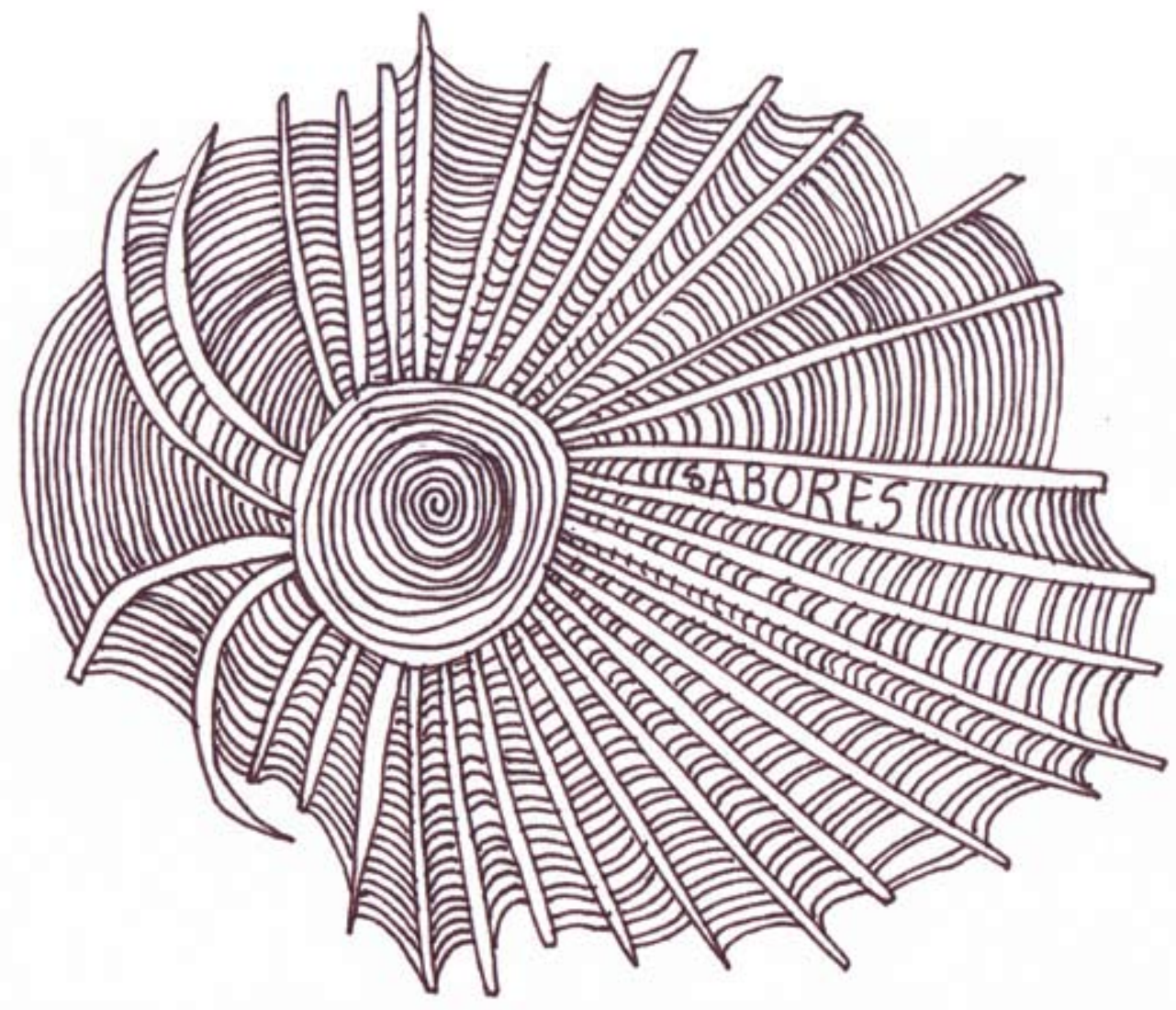




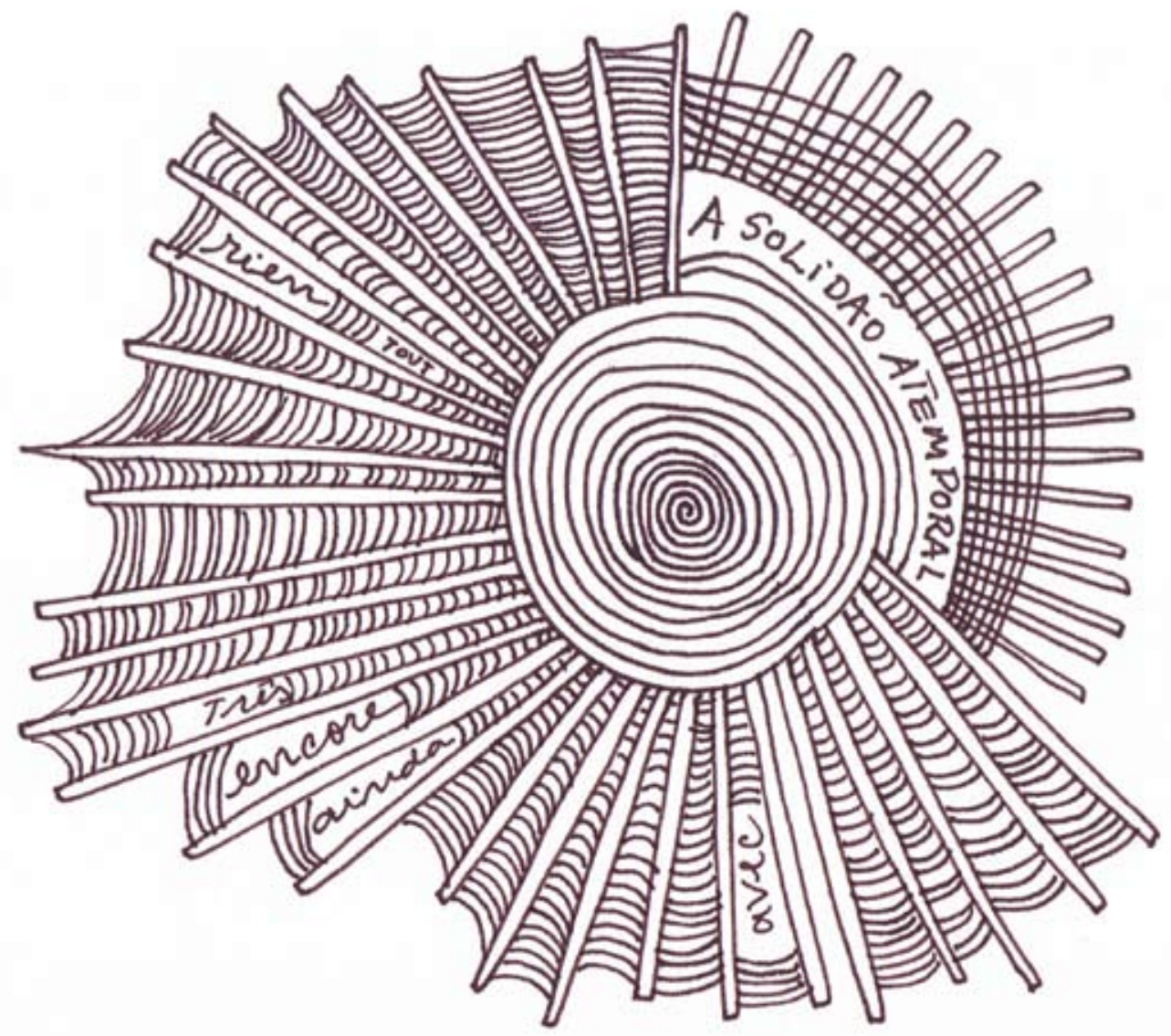




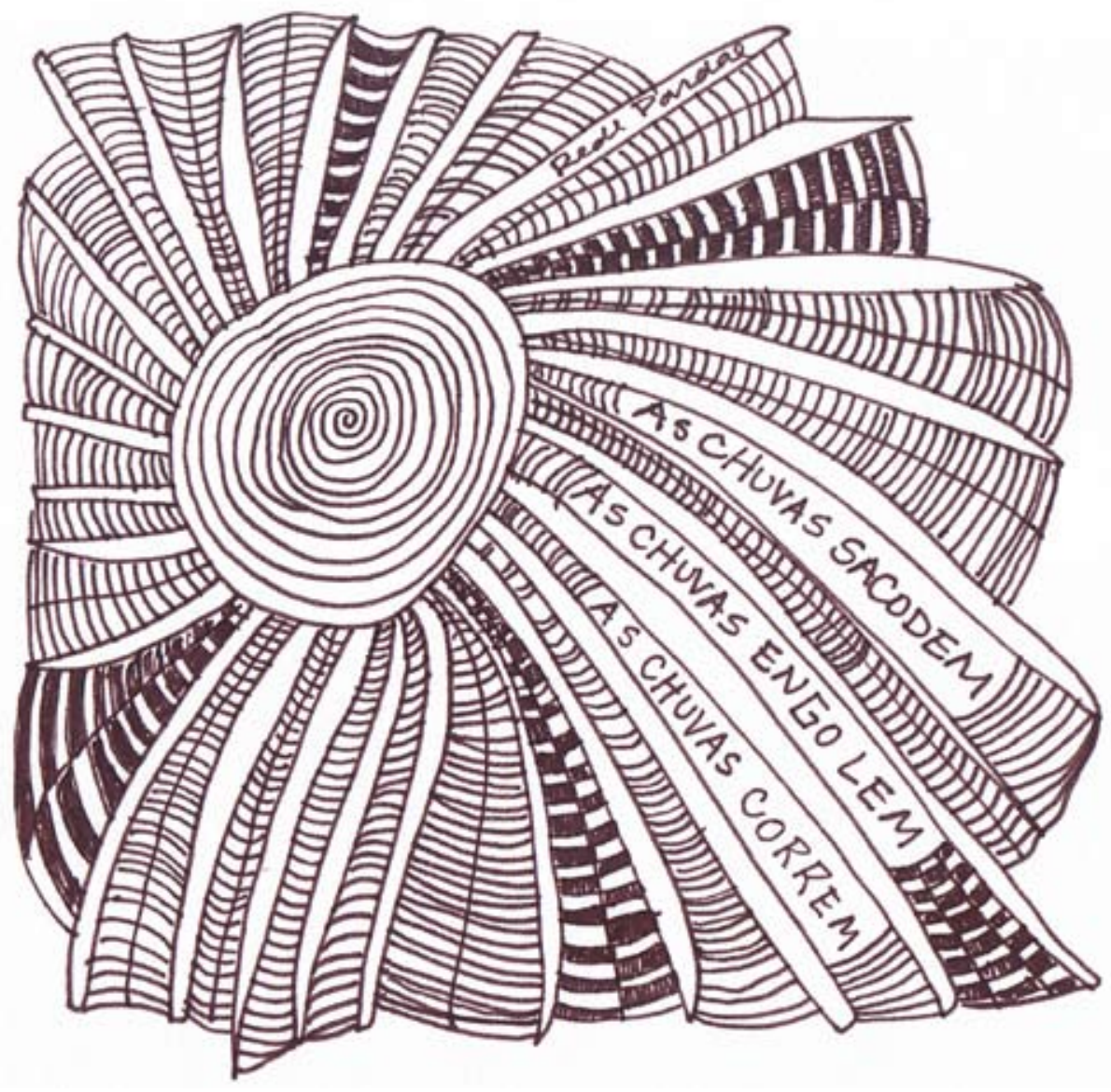


Percursos

As palavras são estrelas,

firmamento suspenso nas sombras. 
"O sonho é ver formas invisíveis Da distância imprecisa, e, com sensiveis Movimentos da esp'rança e da vontade, Buscar na linha fria do horizonte A árvore, a praia, a flor, a ave, a fonte -"

Fernando Pessoa, Mensagem 


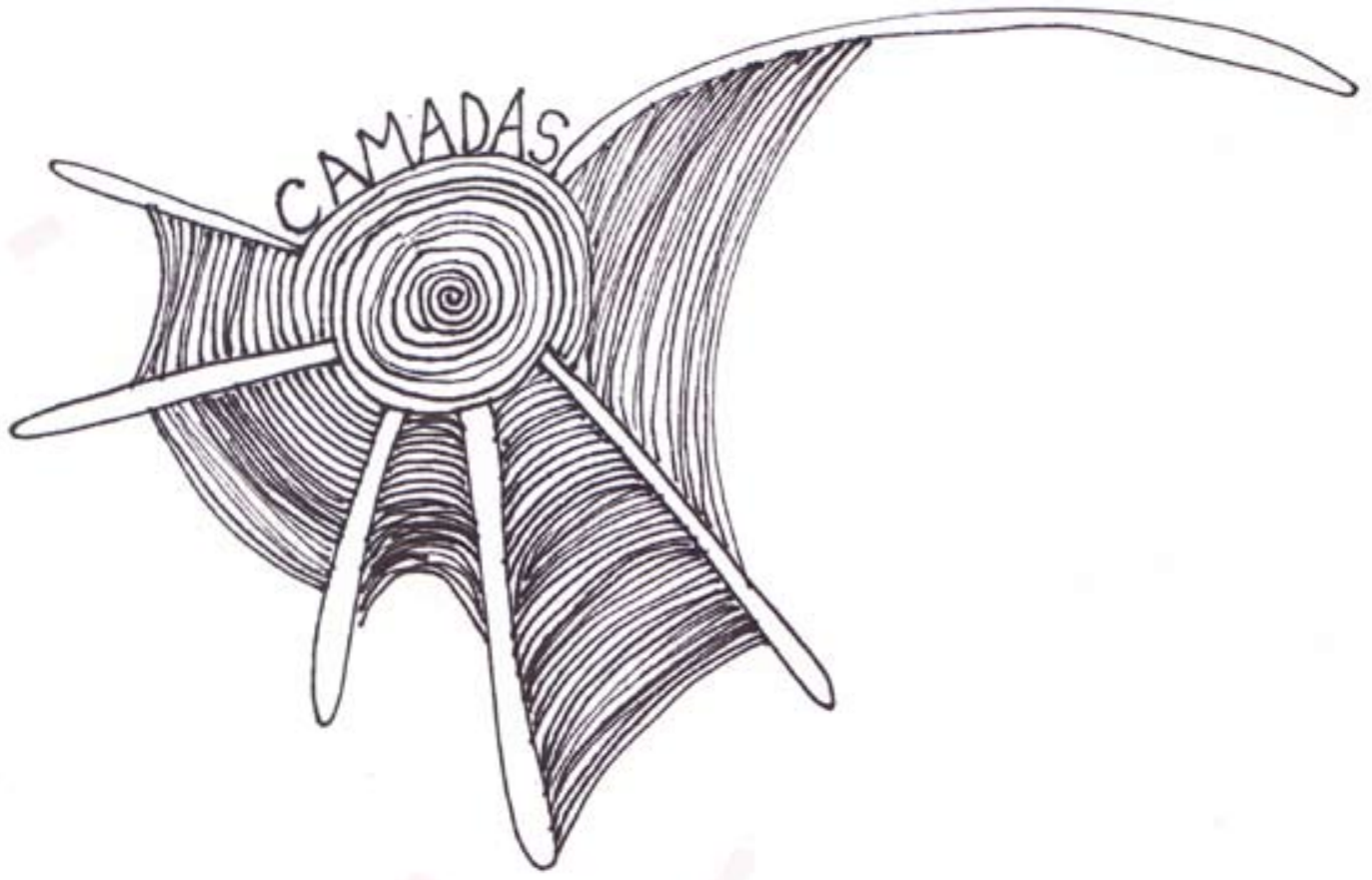




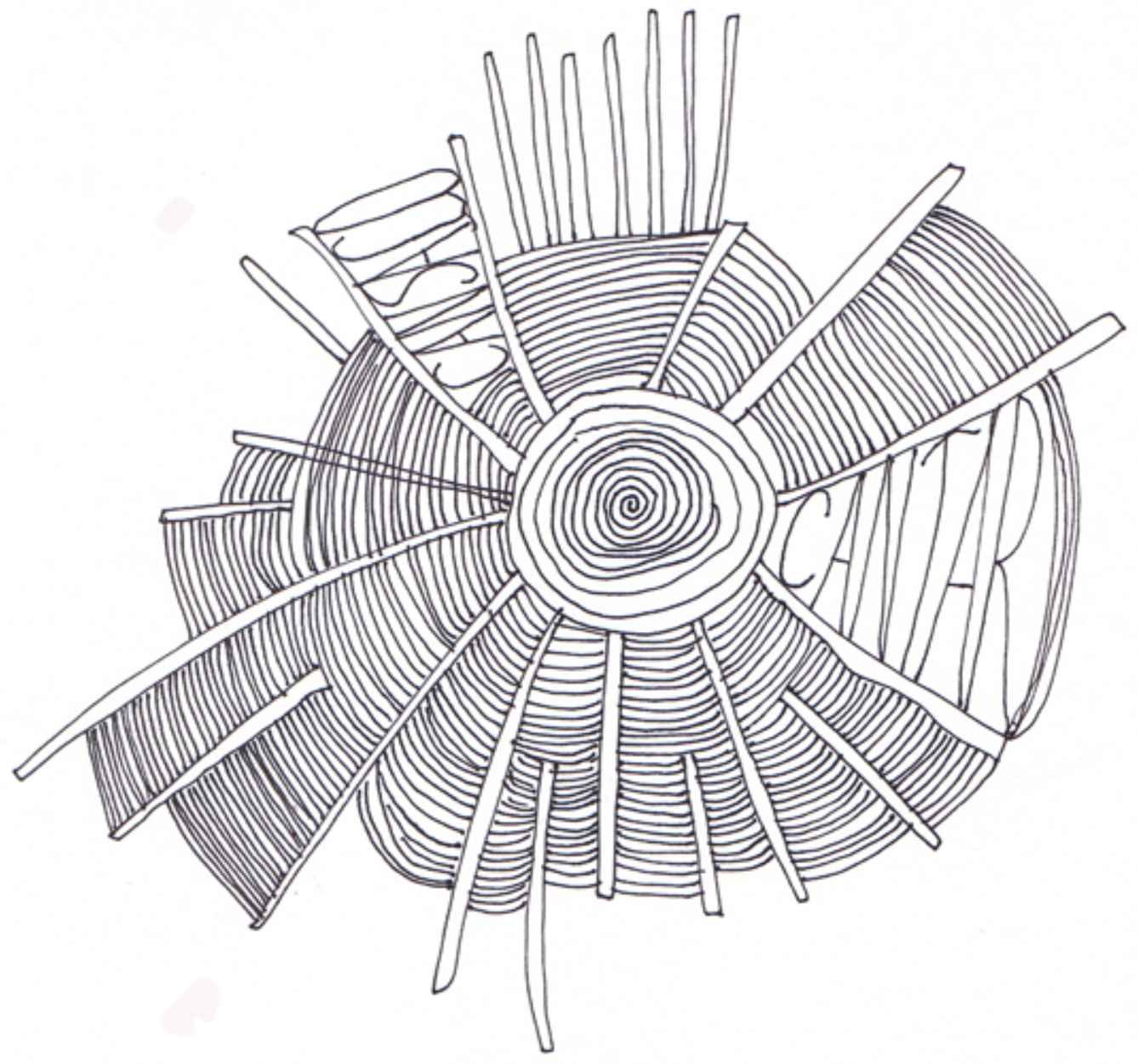




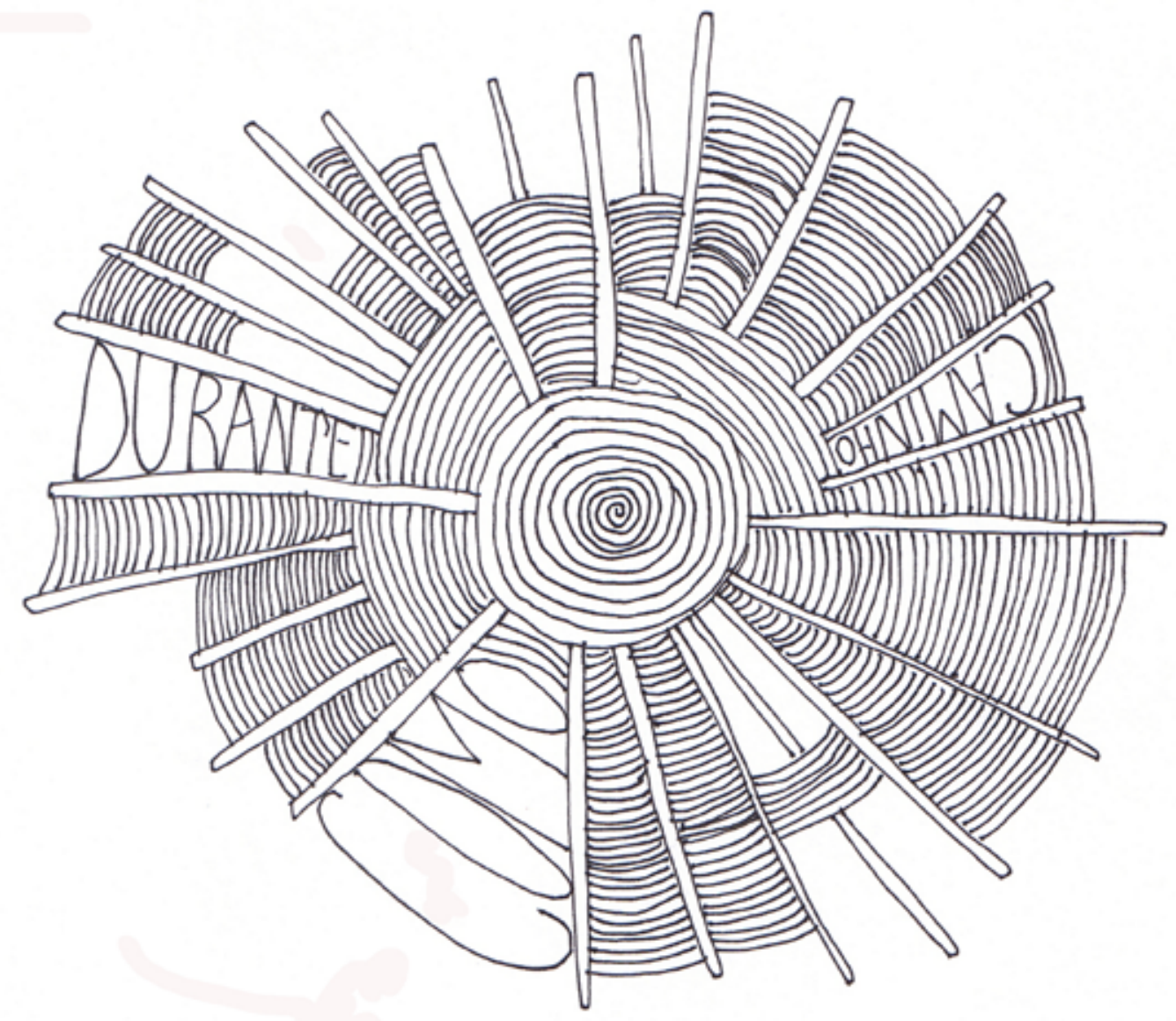




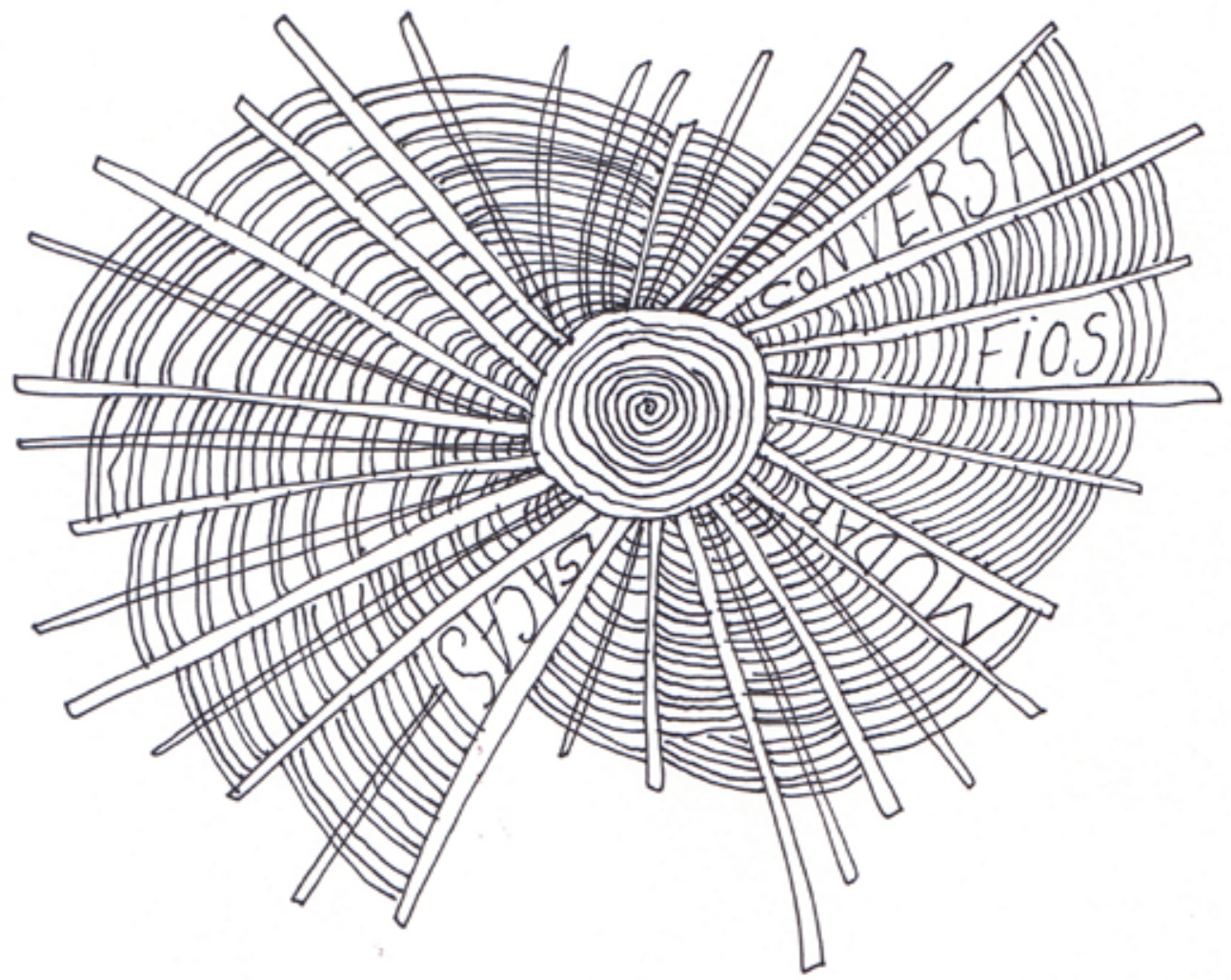




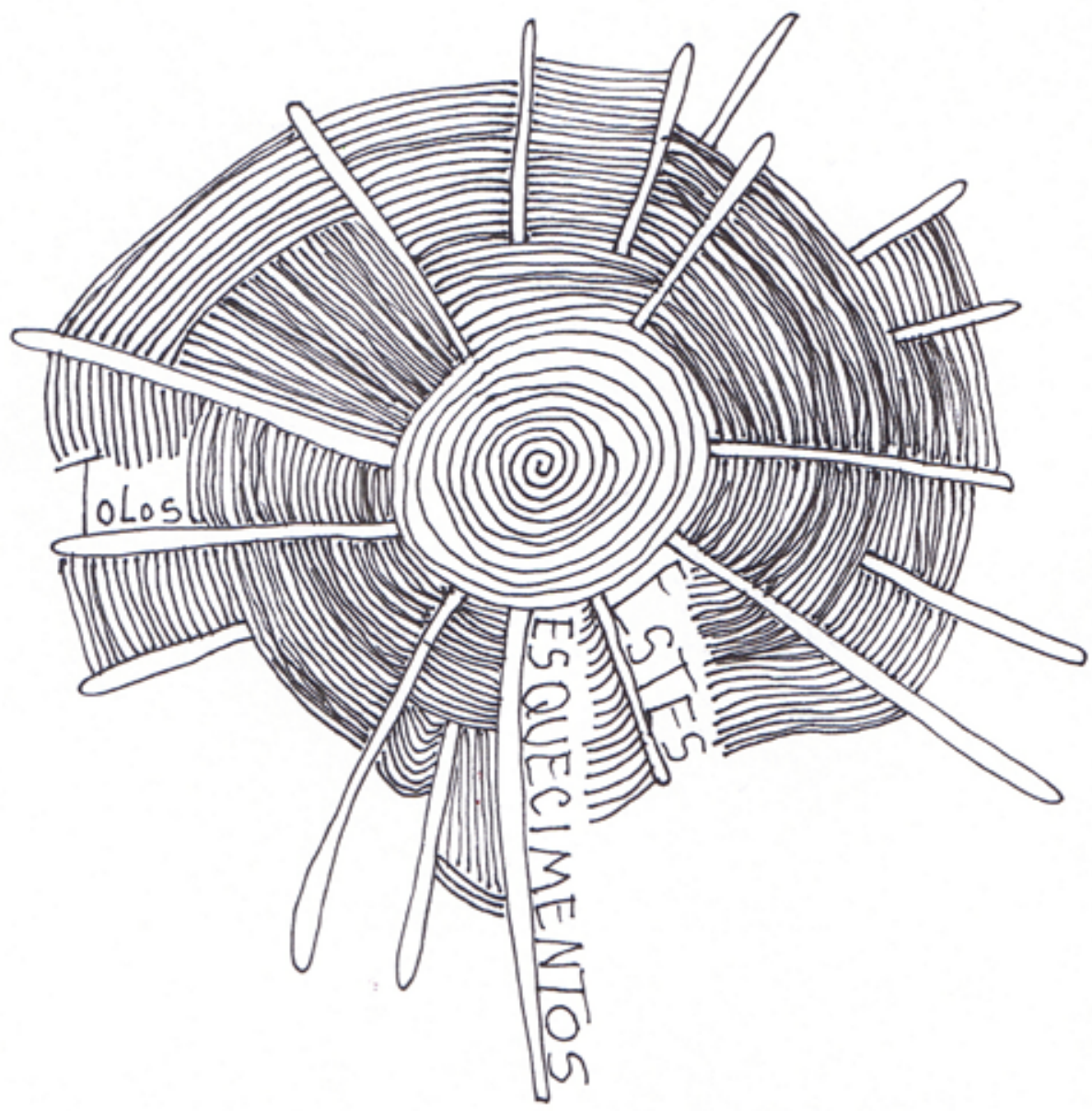




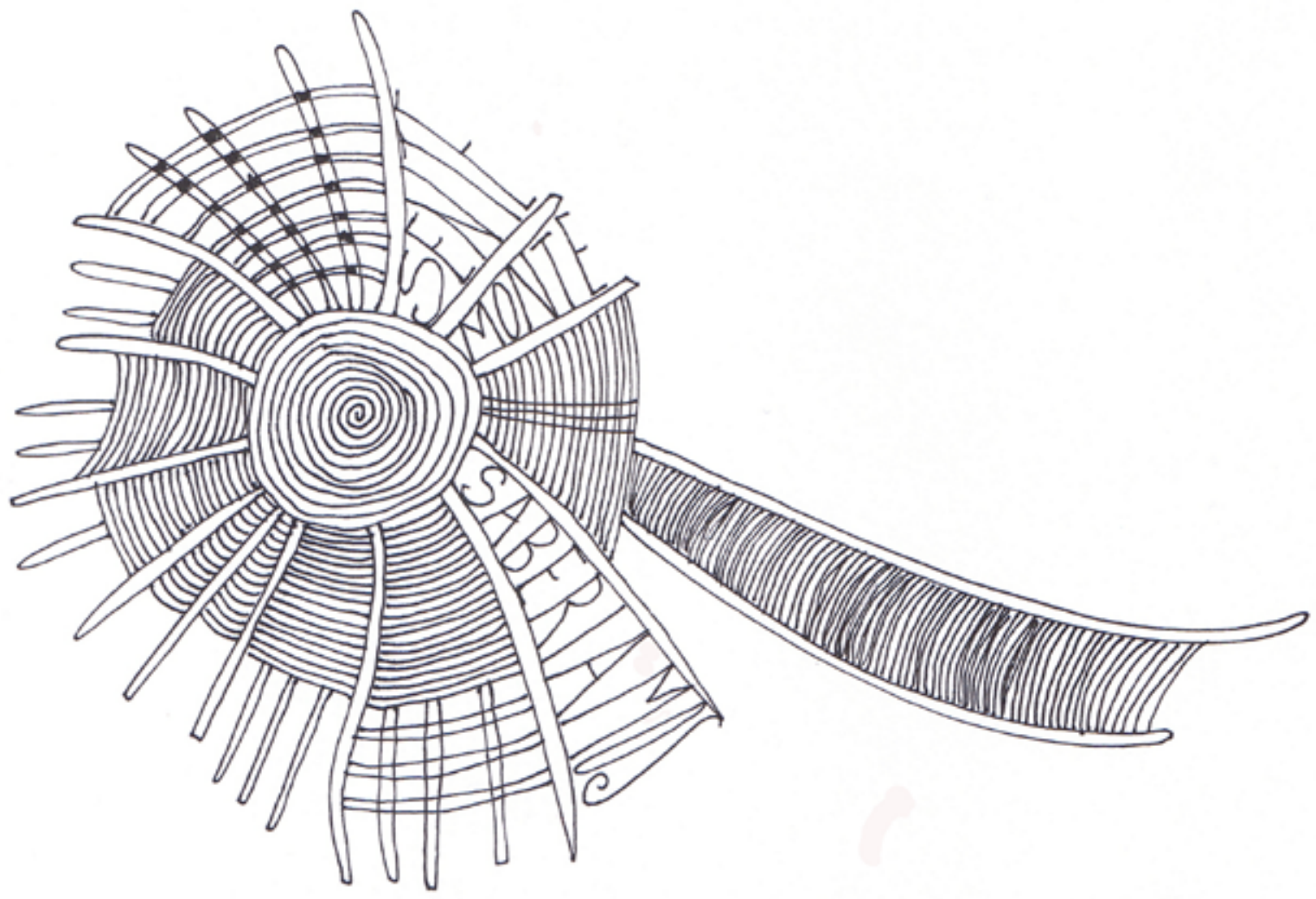




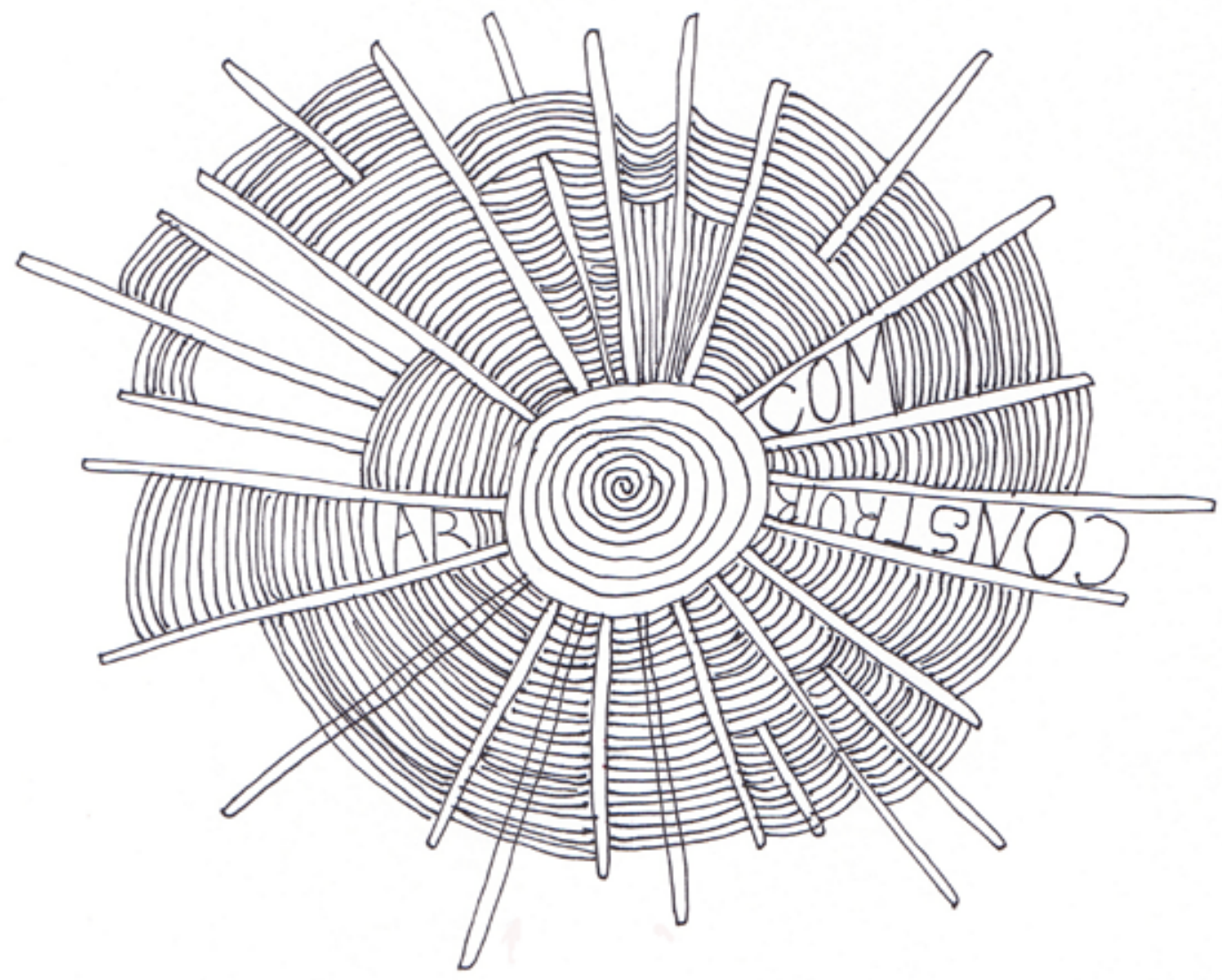




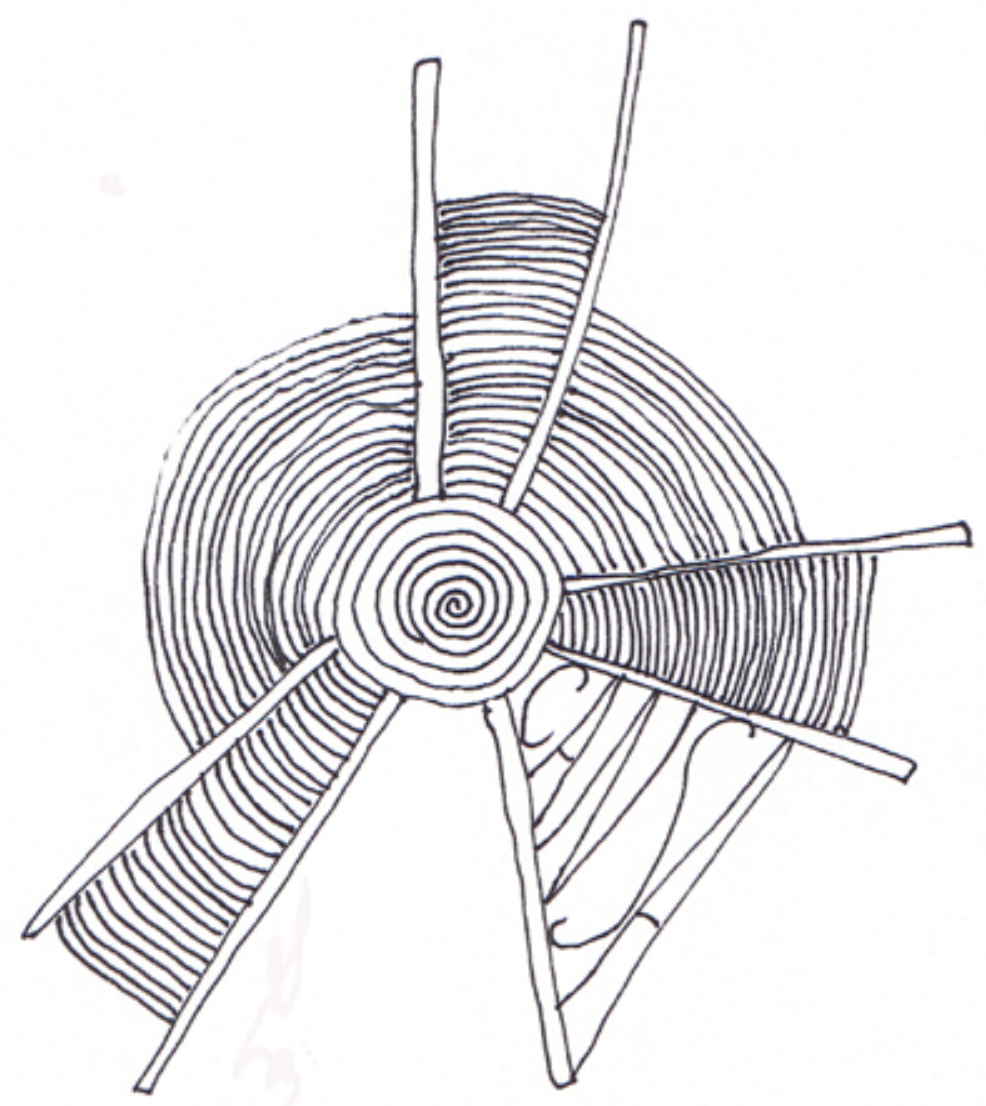




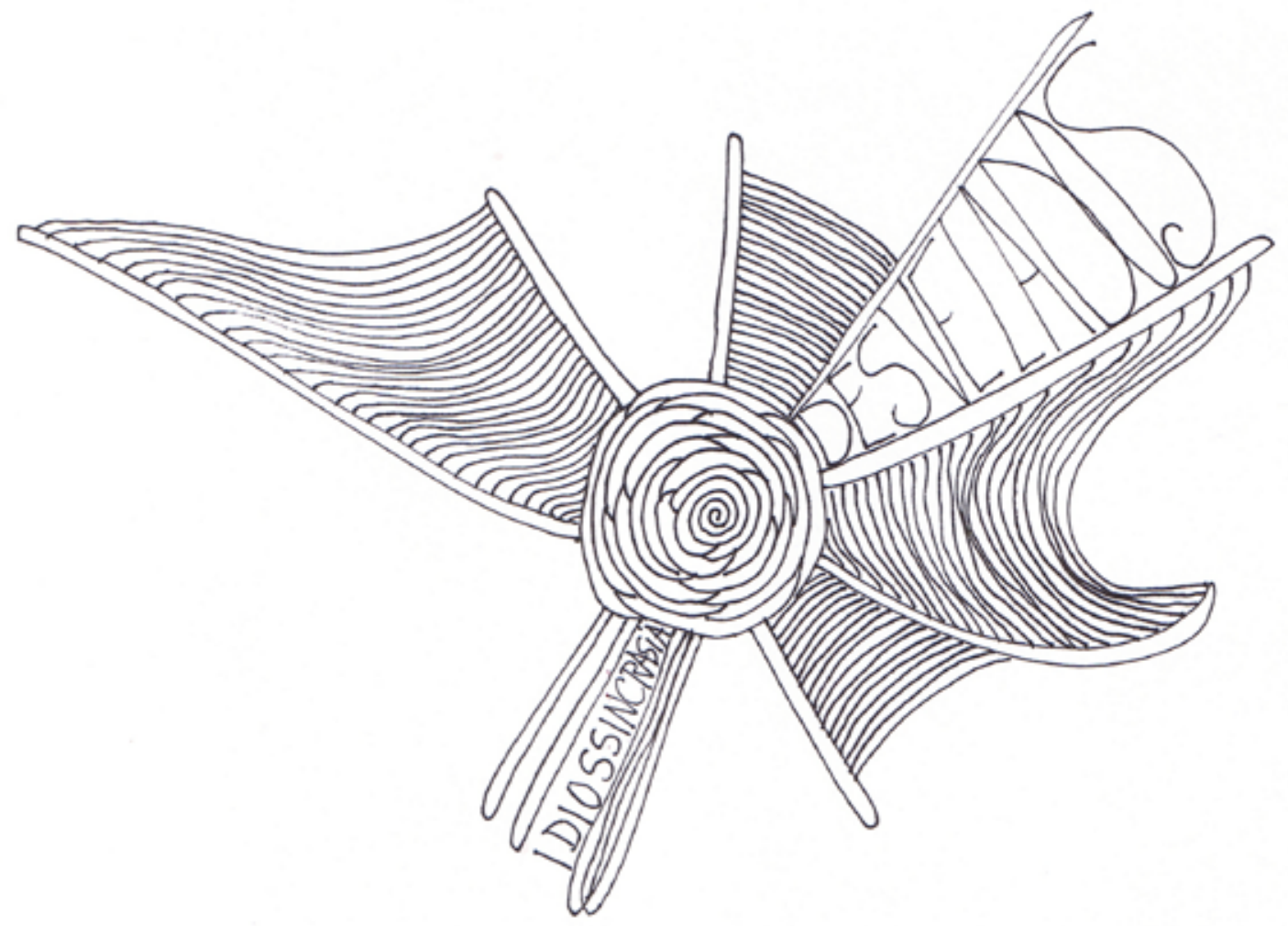




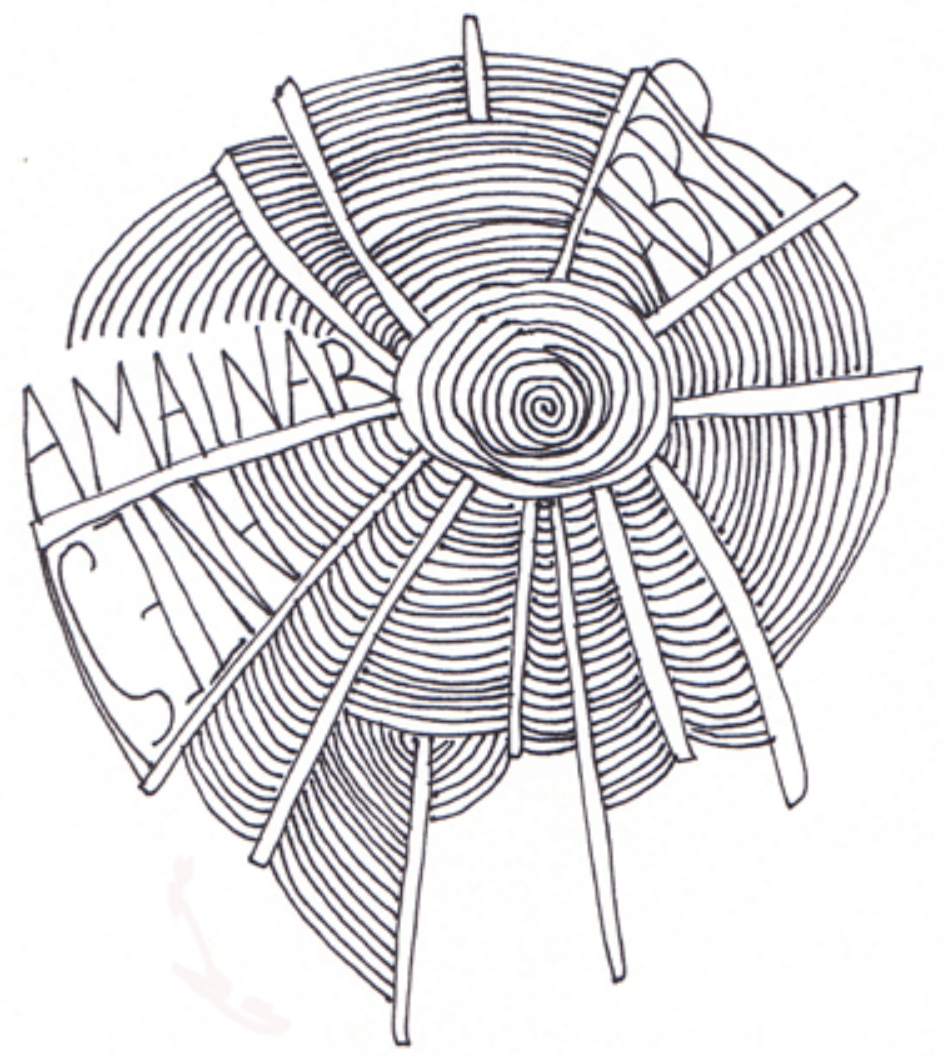




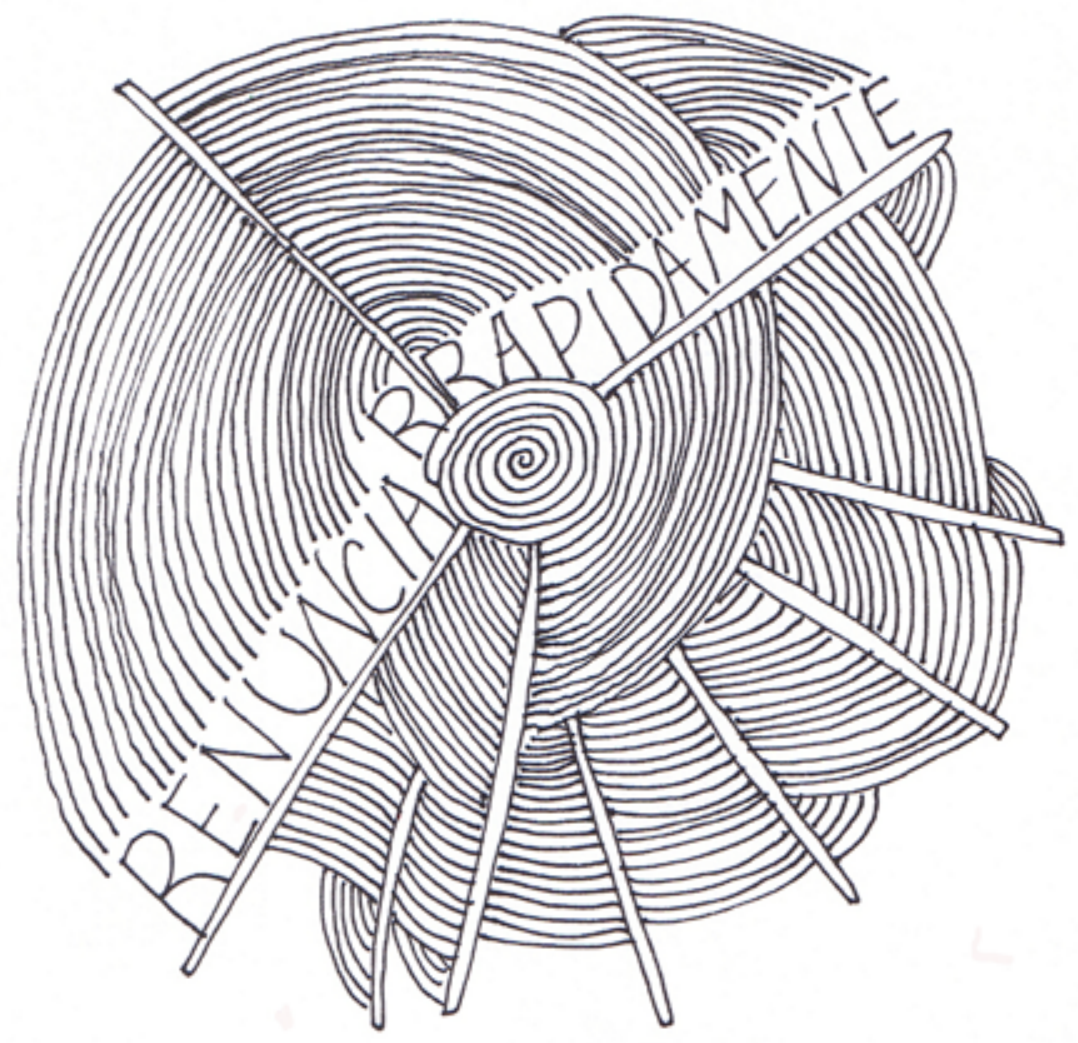




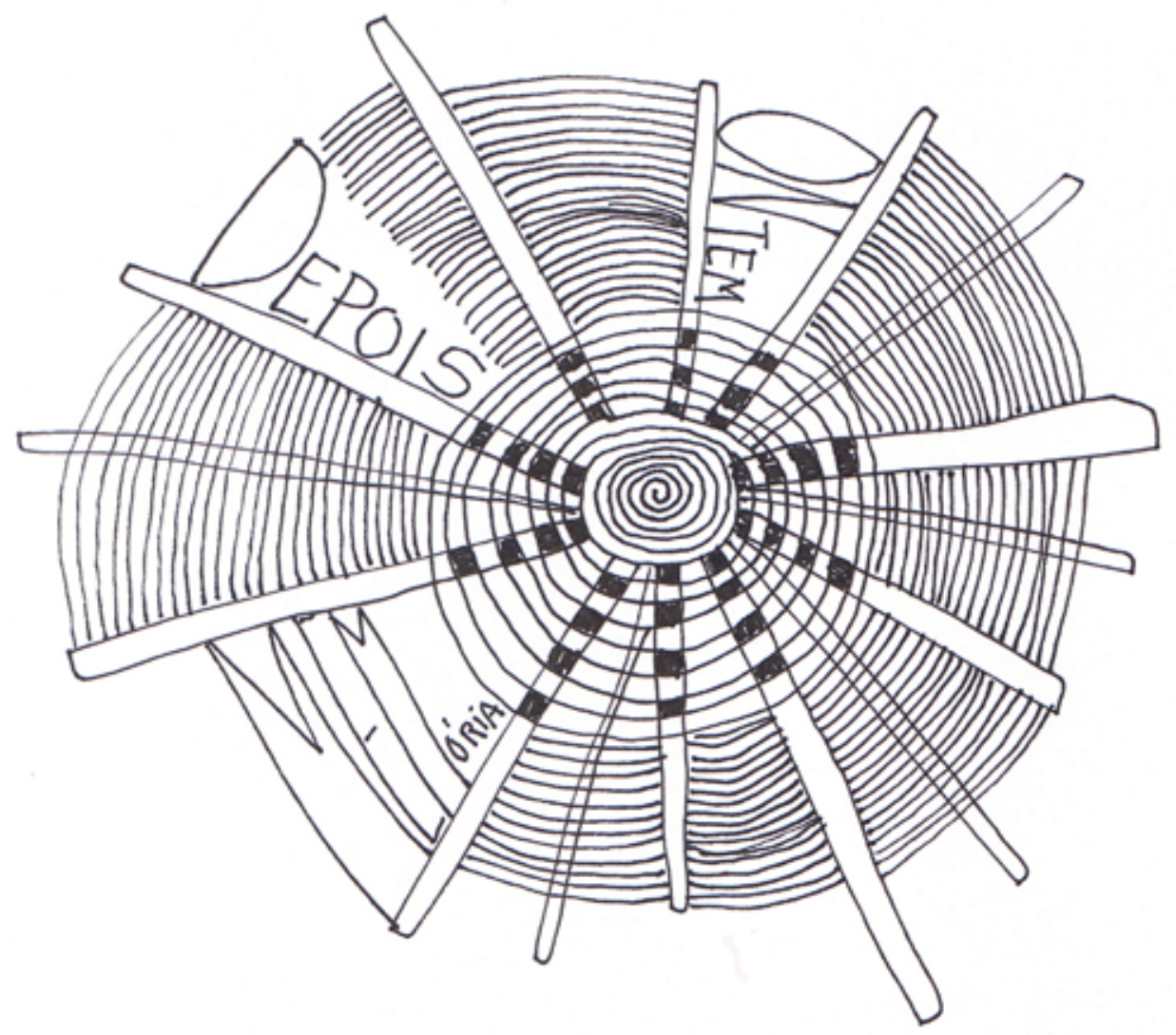




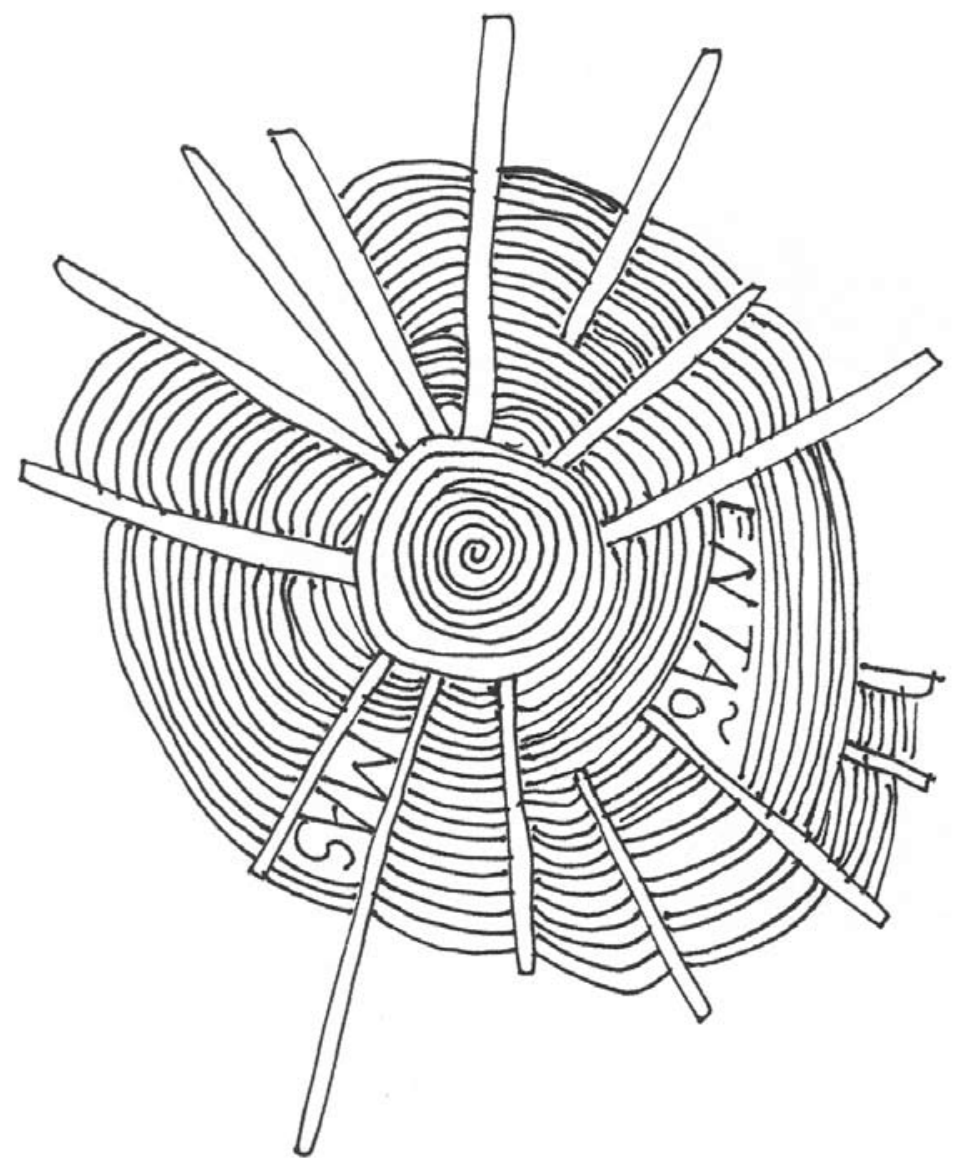




\section{Desenhar ânforas}

é entrar no mundo das demoras, ânforas - sinônimos de viagens.

Ânforas habitam meus desenhos e

têm lugar cativo nos segredos das águas.

São recipientes nos desafios diários, onde vozes ecoam sonoridades e tecem redes nas linhas desenhadas por cantigas além do horizonte.

Nelas saboreio as raízes das minhas paisagens maternas. 


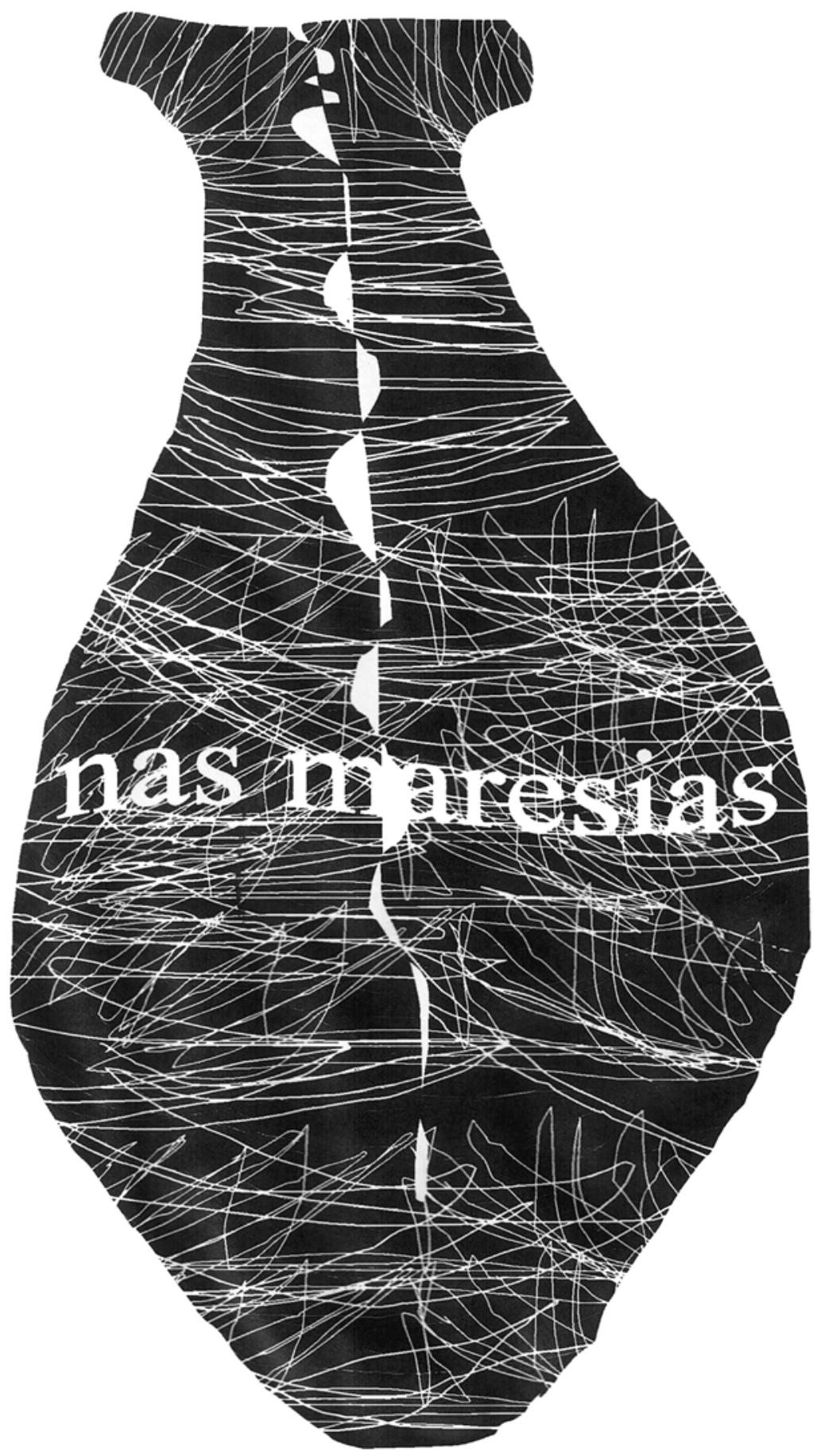




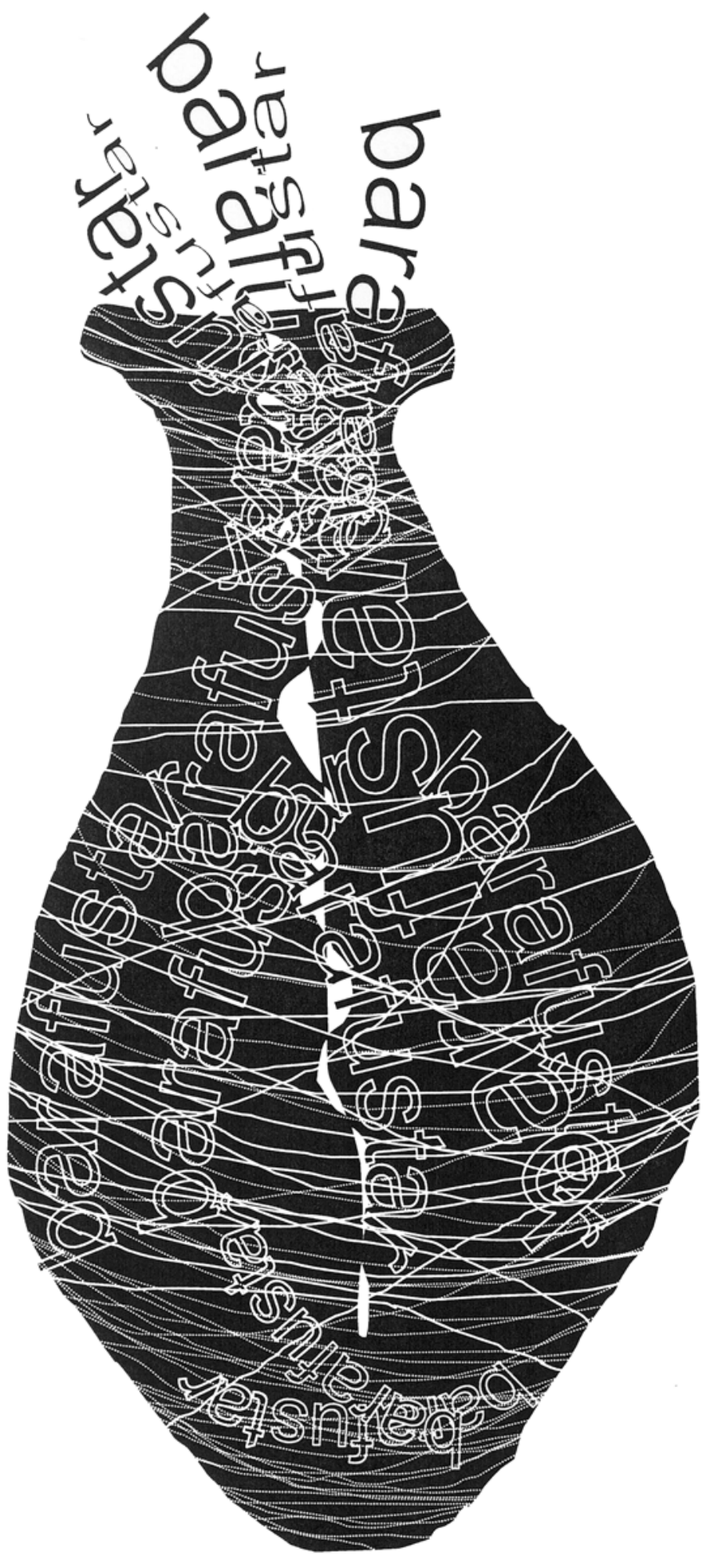




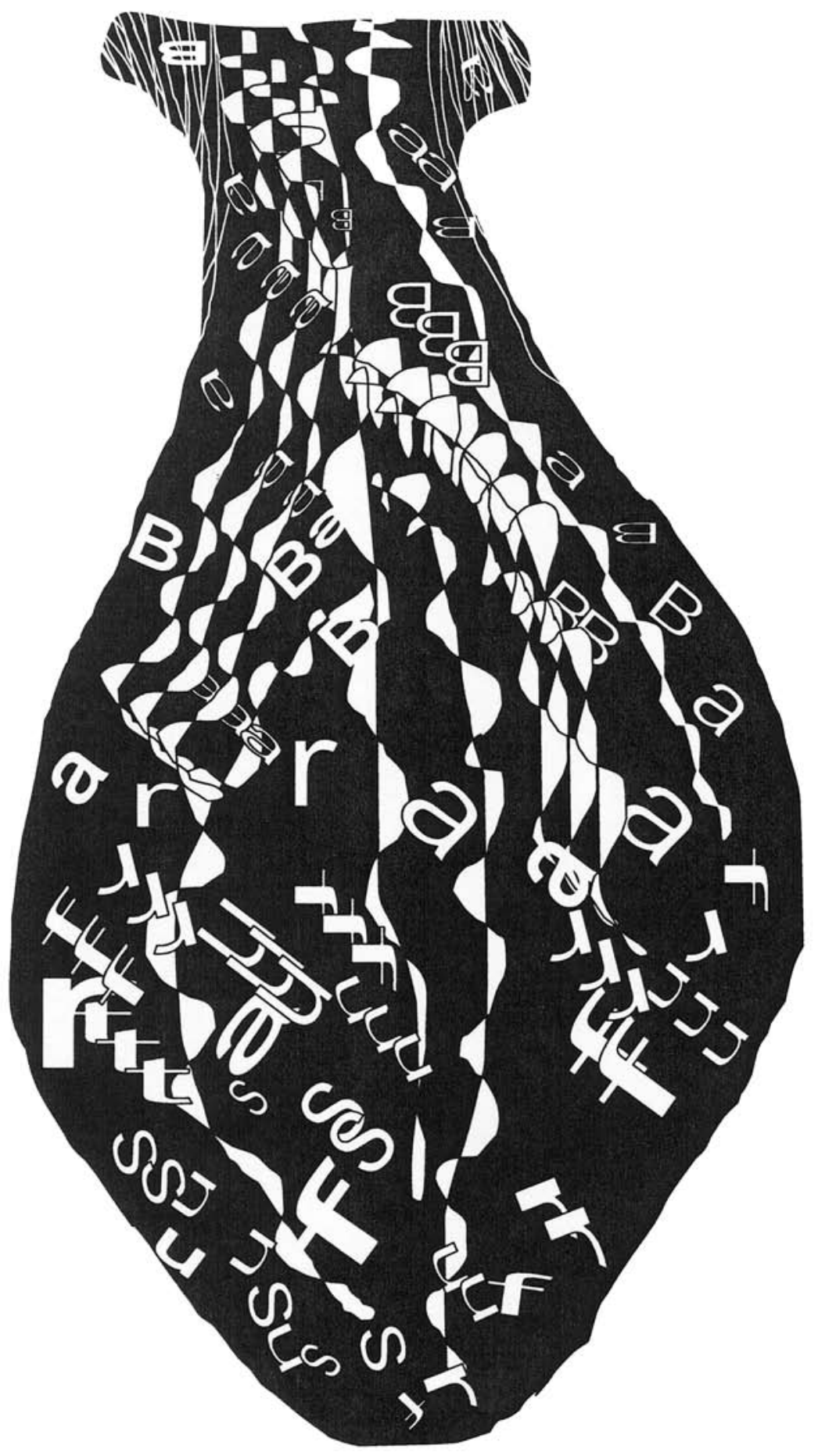




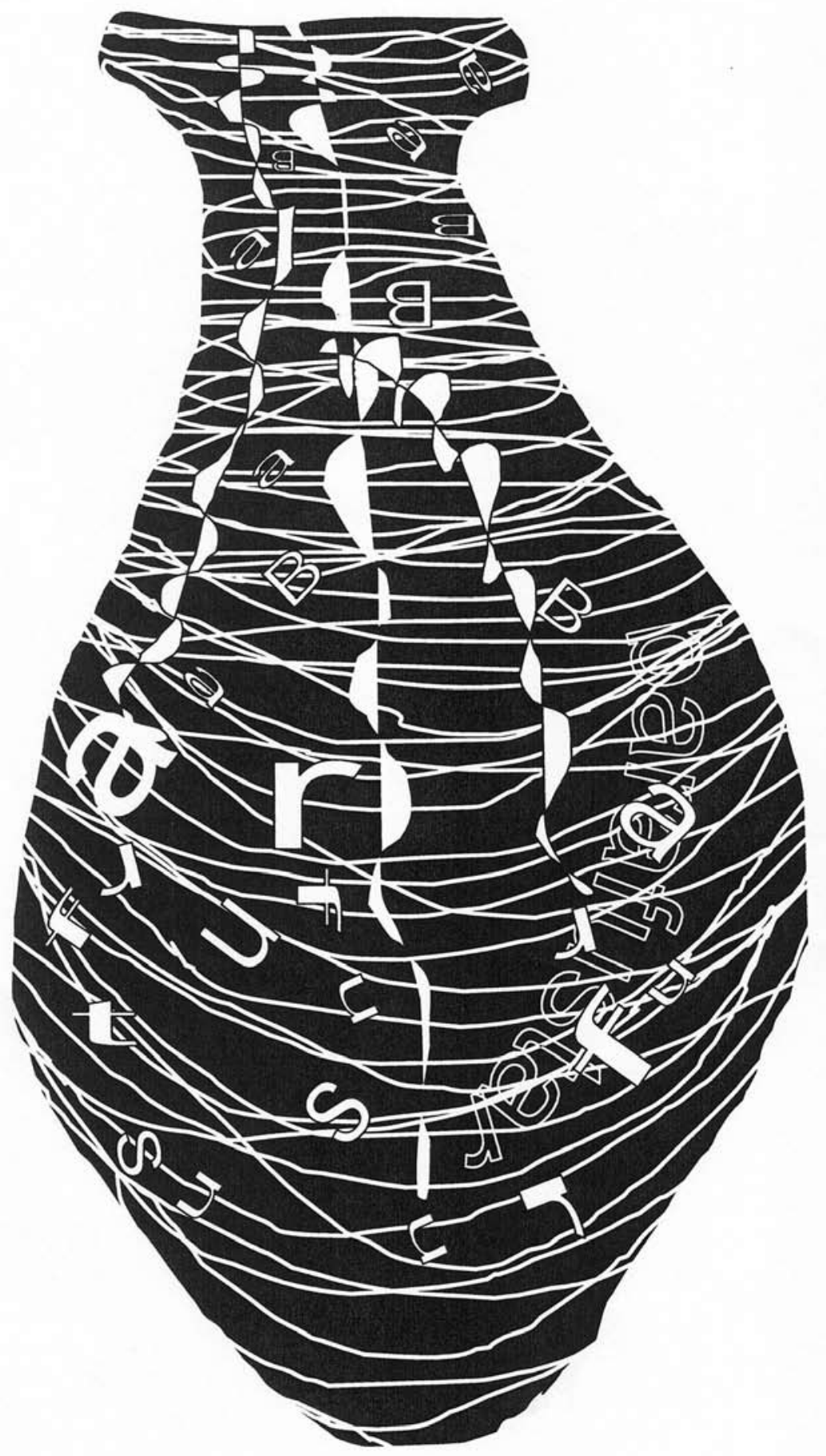




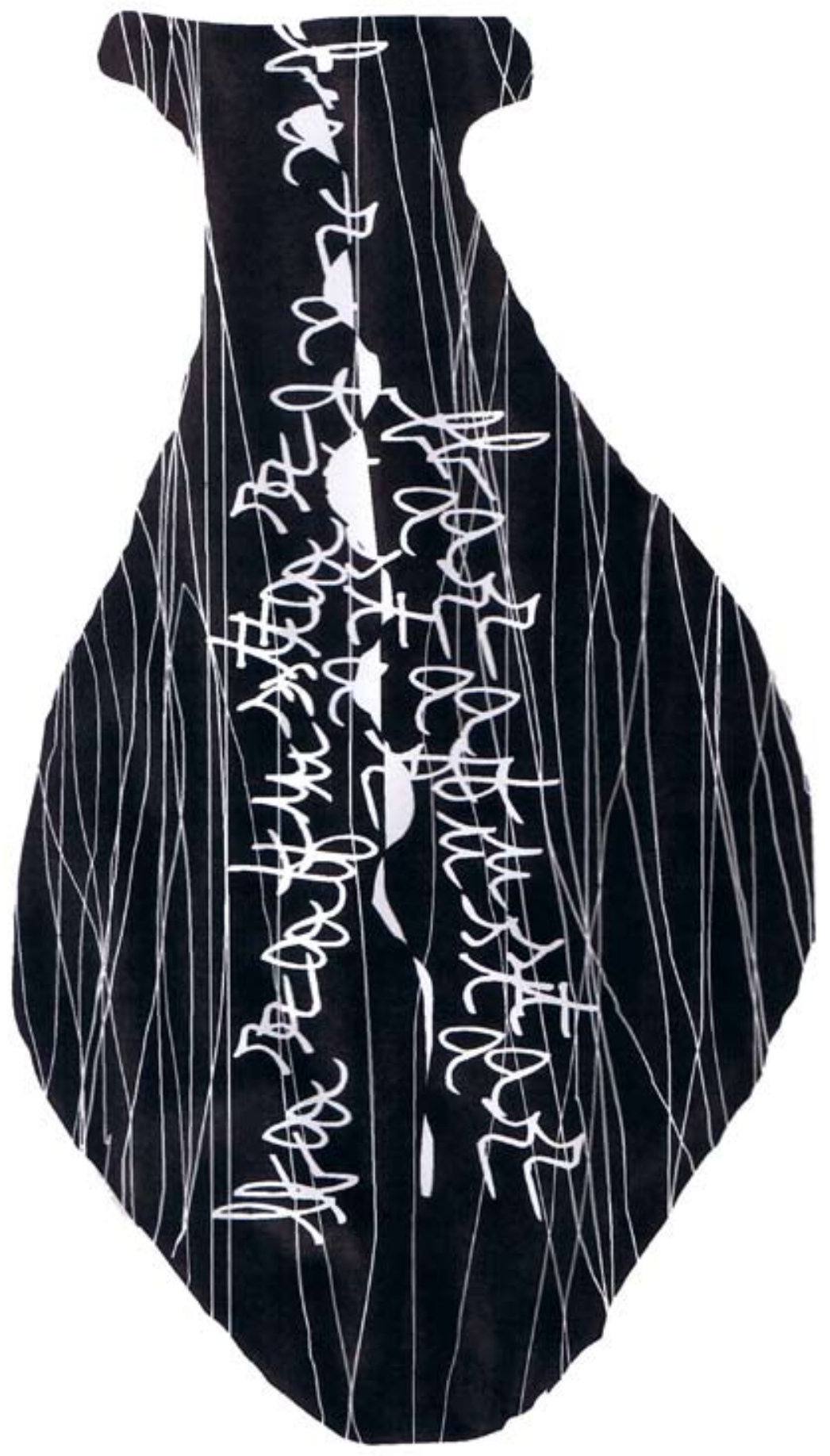




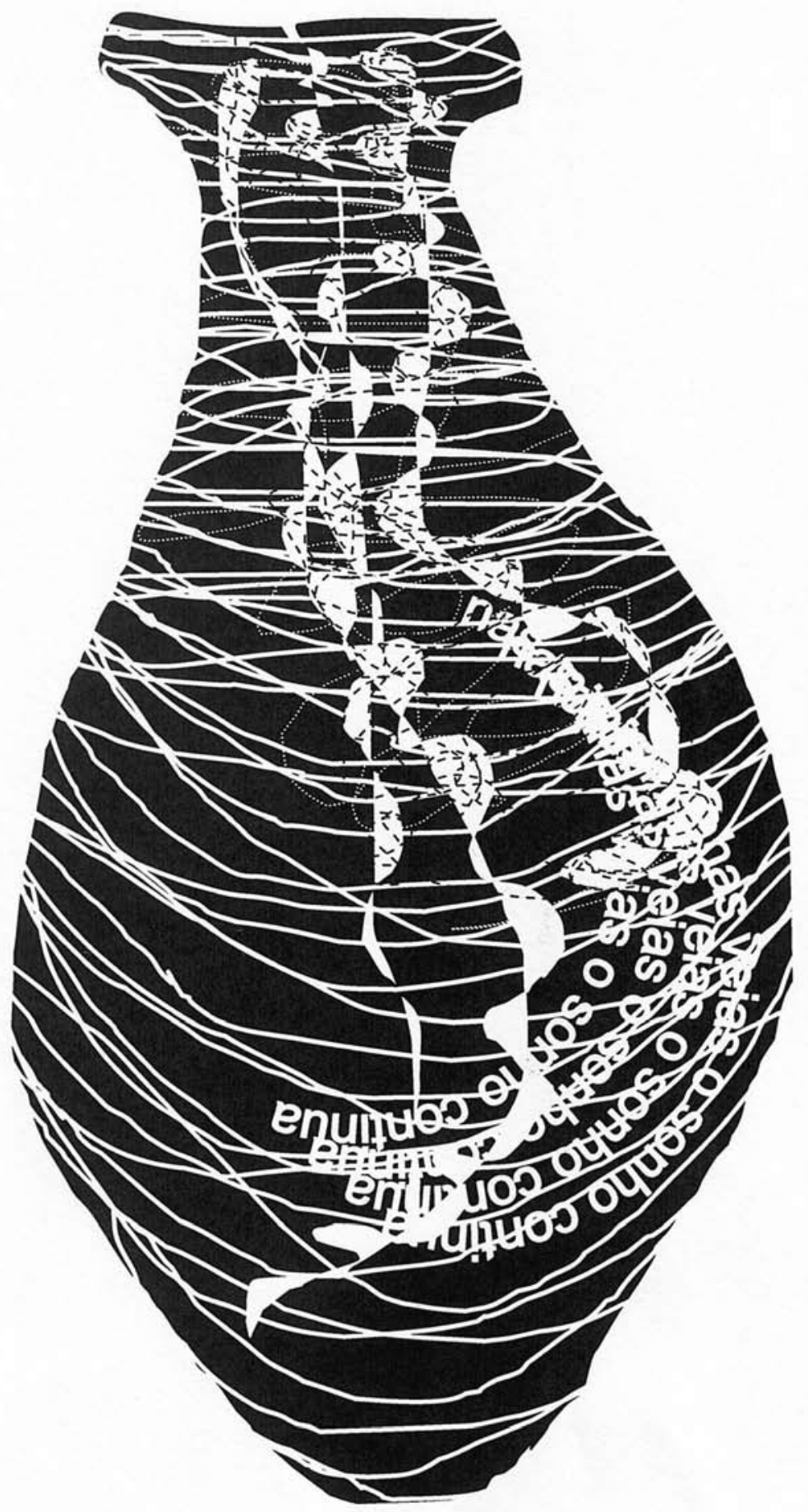




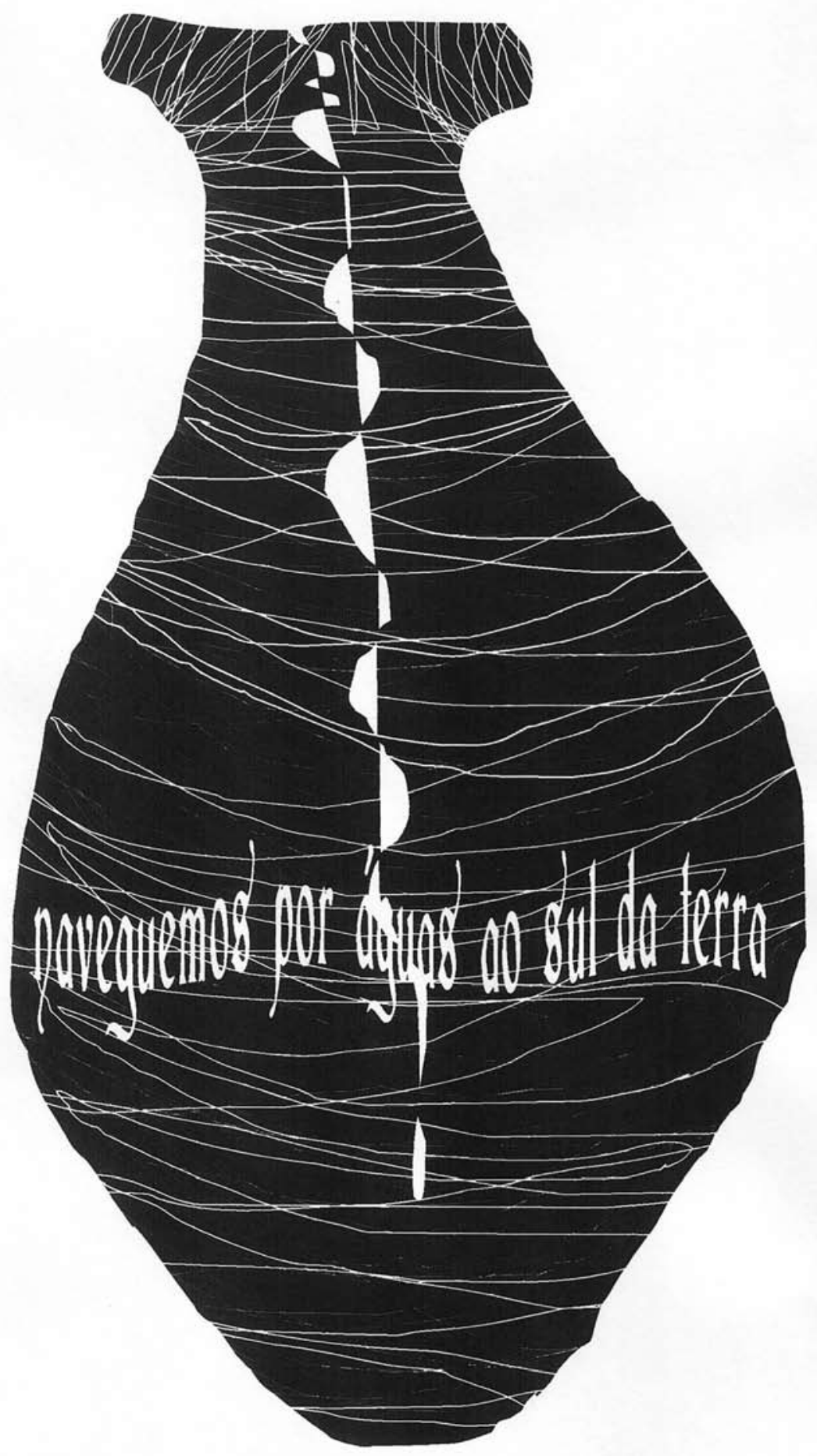




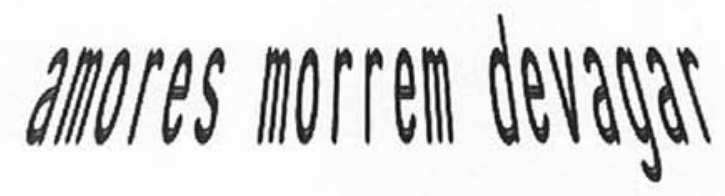

amores mor rem devagar

amores mor rell devagar

amores morrem devagar

amores morrem devagar

amores morrem devagar

amores morrem devagar

amores morrem devagar

amores morrem devagar

amores morrem devagar

amores morrem devagar

devagar devagar

morrem 


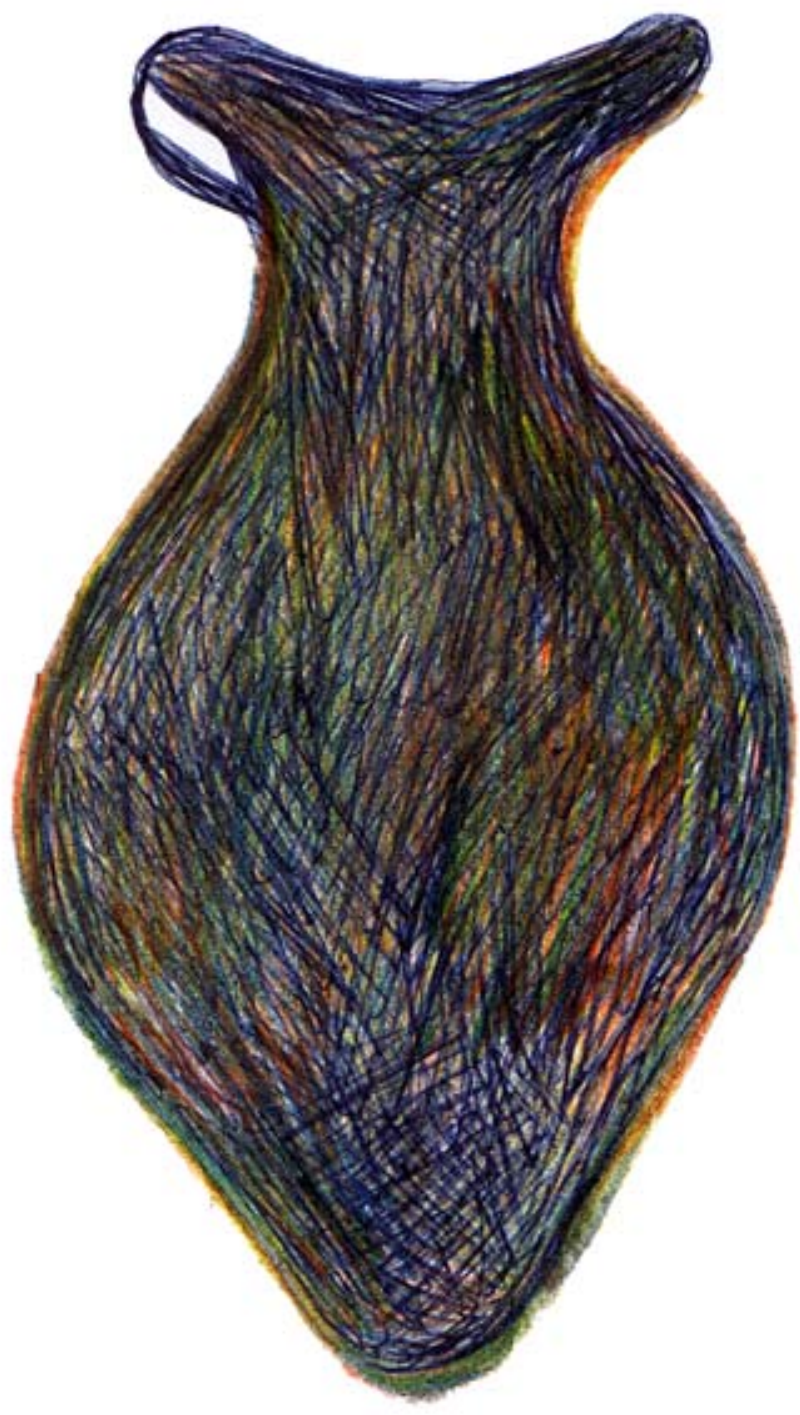




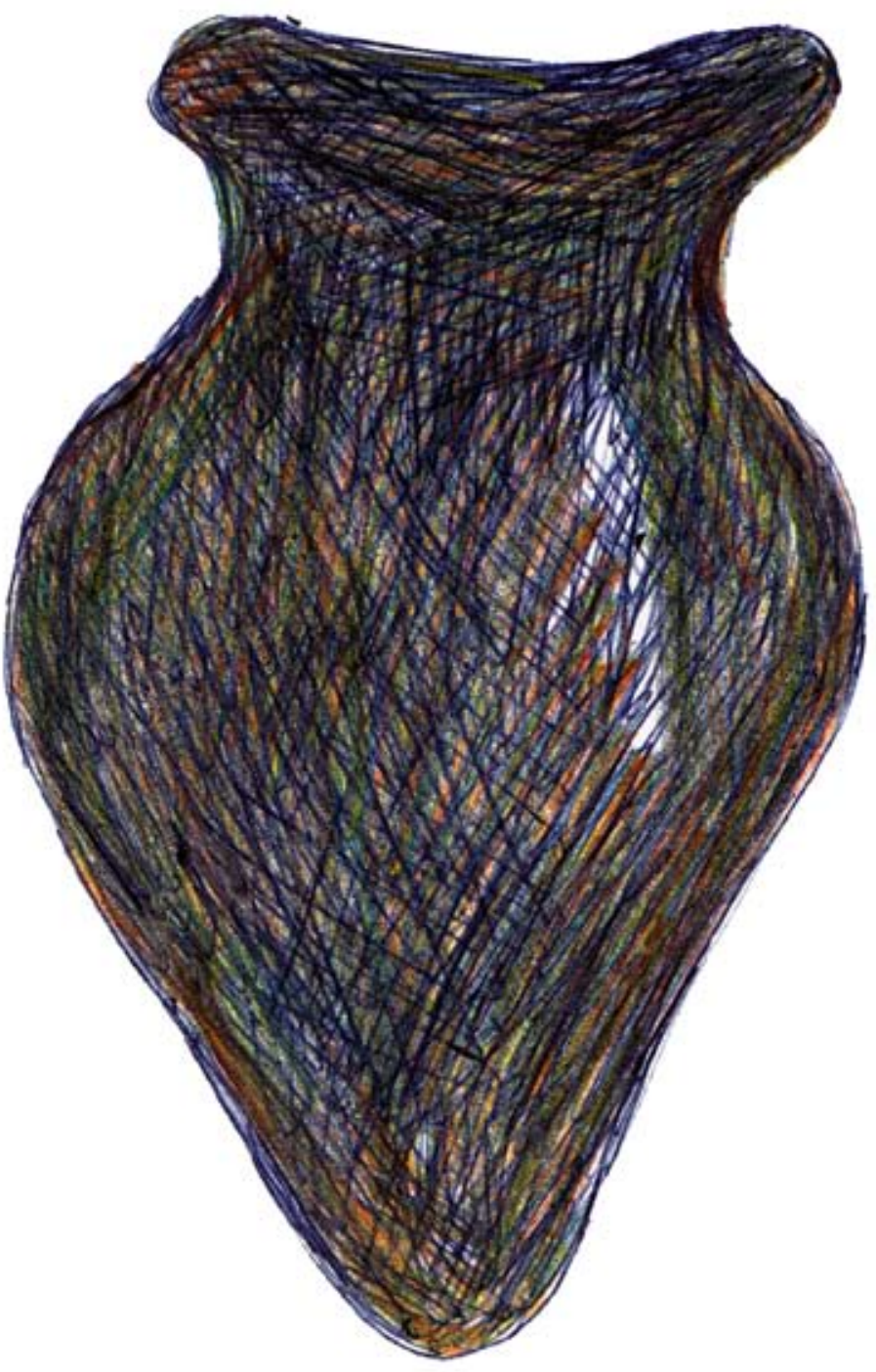




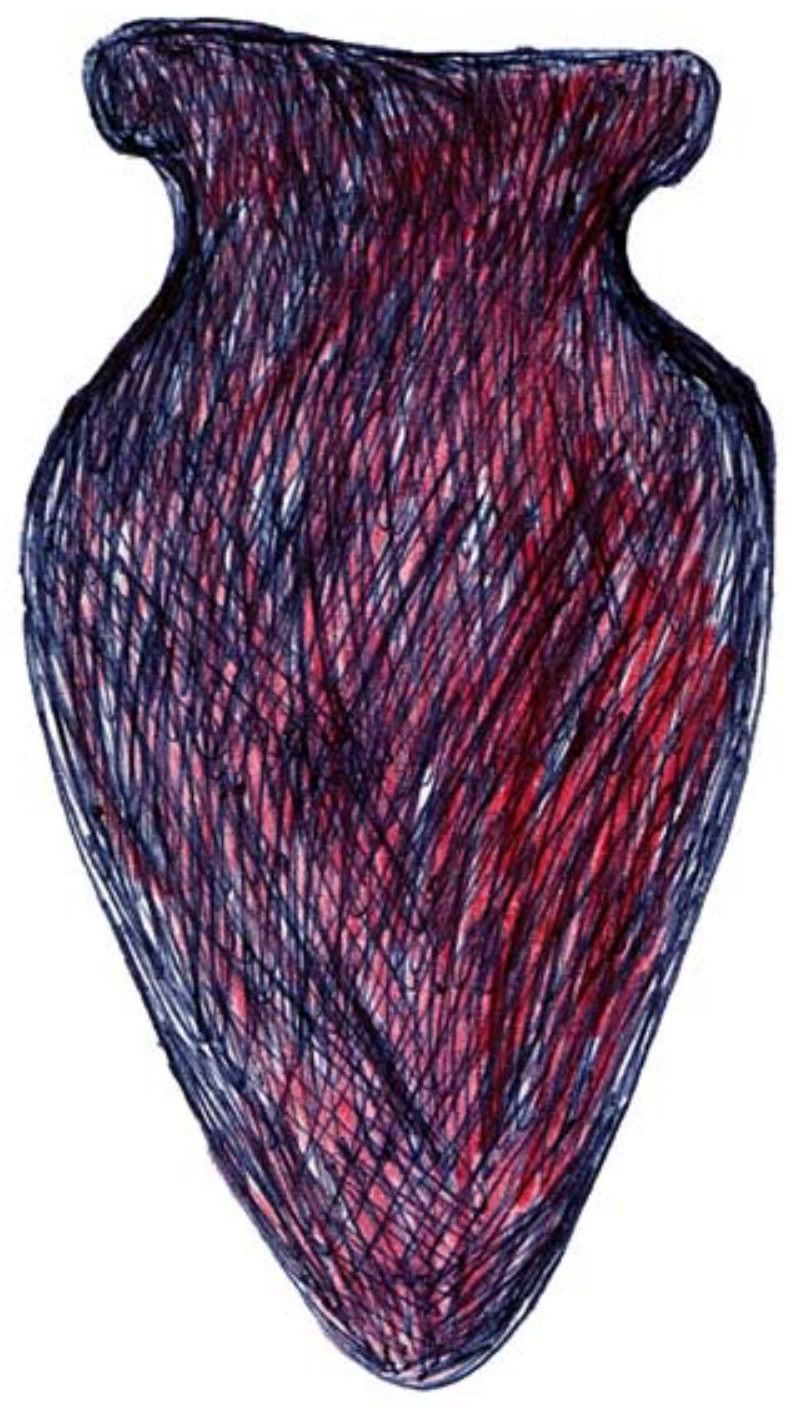


Nos livros de artista experimento entre as

fronteiras da poesia e das artes visuais. Exploro

a palavra como elemento visual, numa sequência

de momentos, sintaxes próprias e vivências do cotidiano.

A escolha do formato de livro acontece pelo tato, o tempo, o volver a página, o fluxo de páginas, o mistério da narração folha após folha, a tridimensionalidade e a participação de quem folheia o livro de artista. 


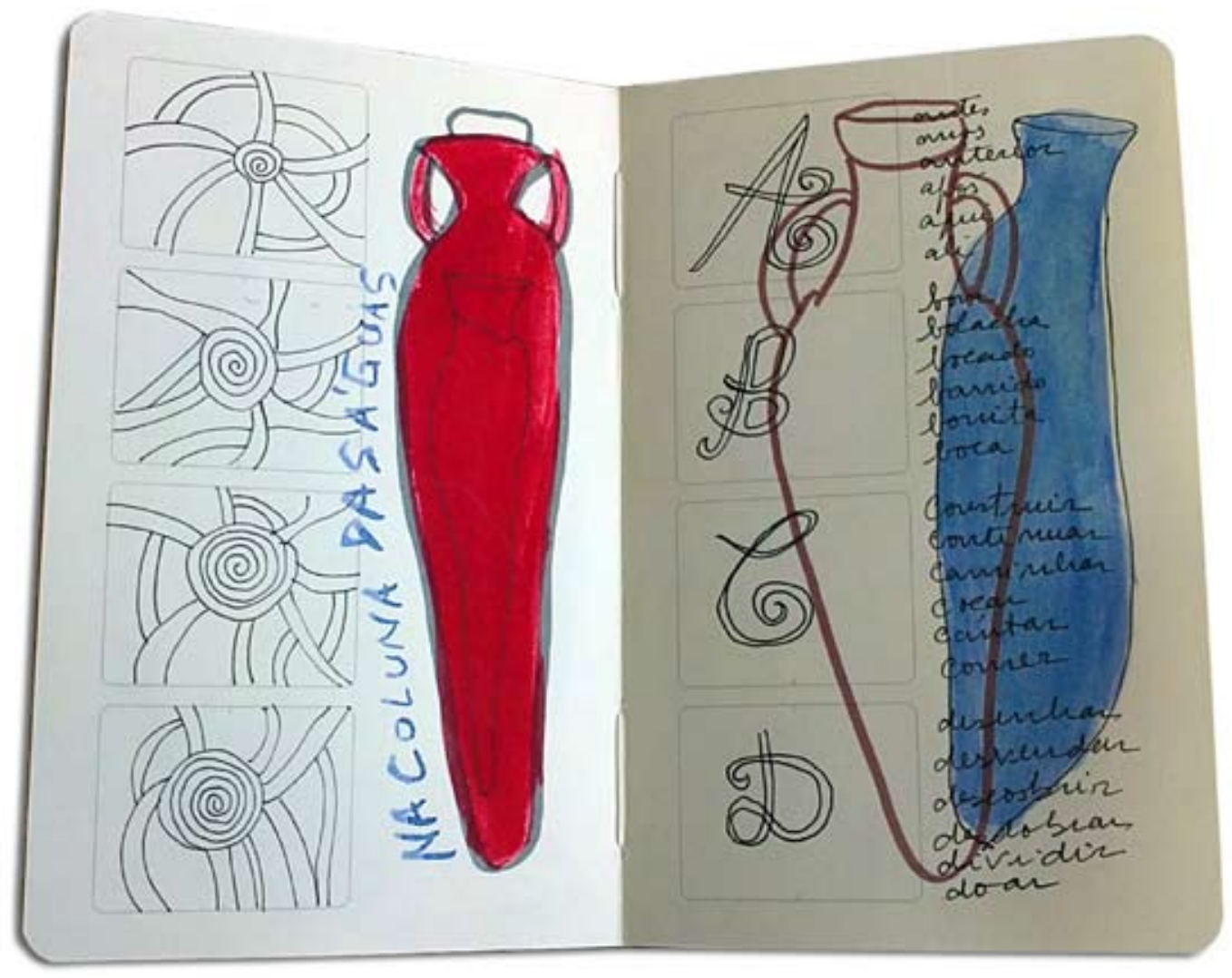




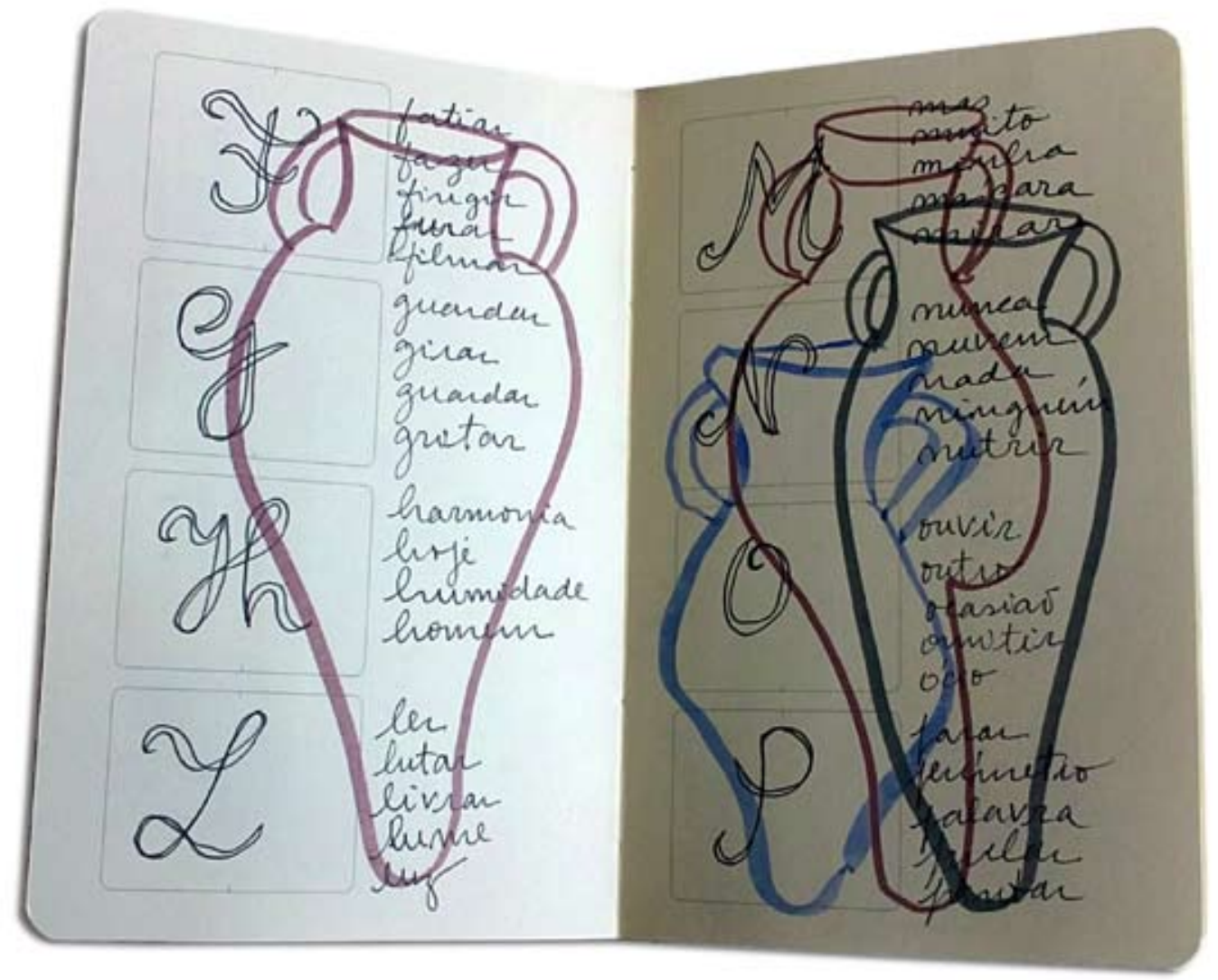




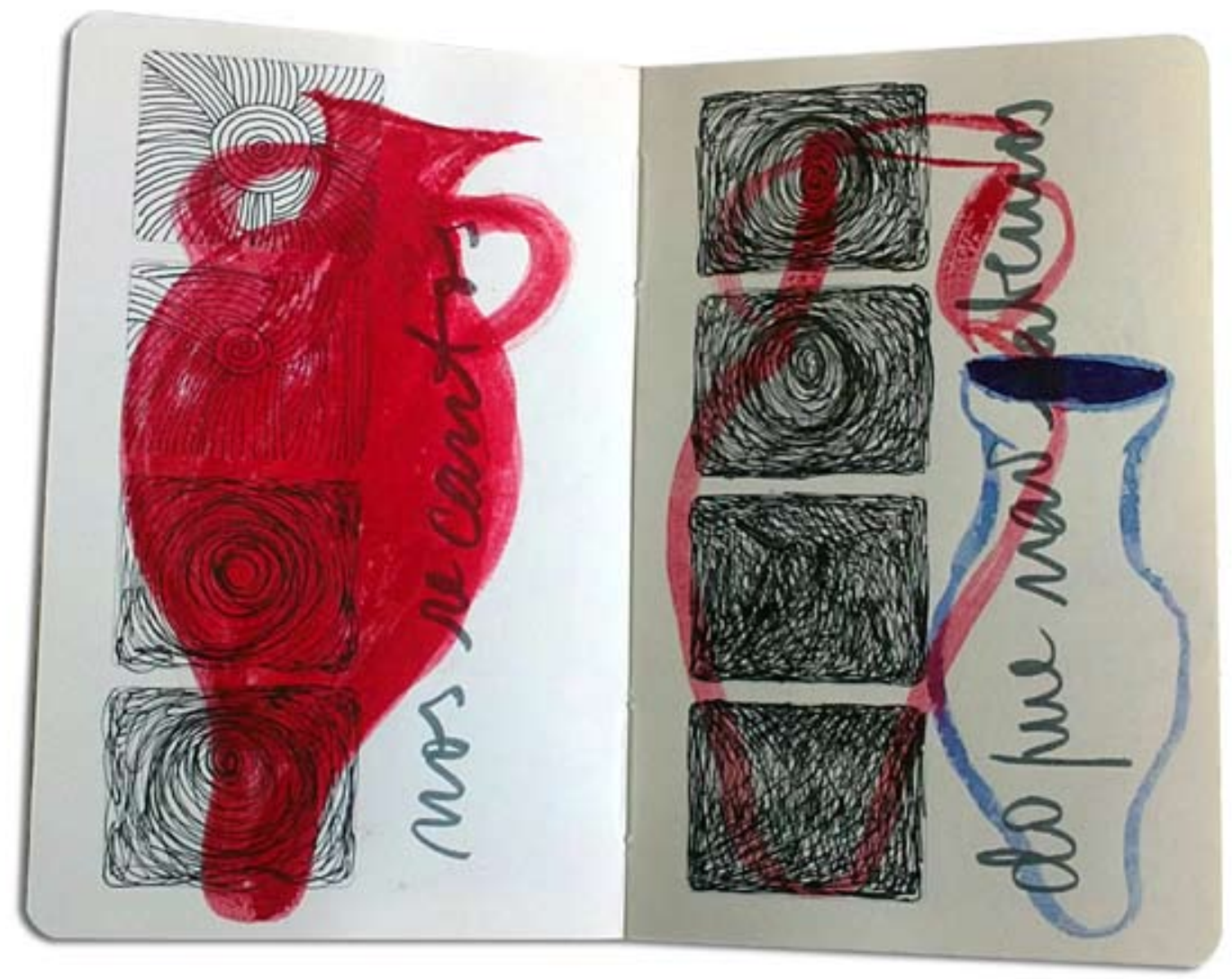




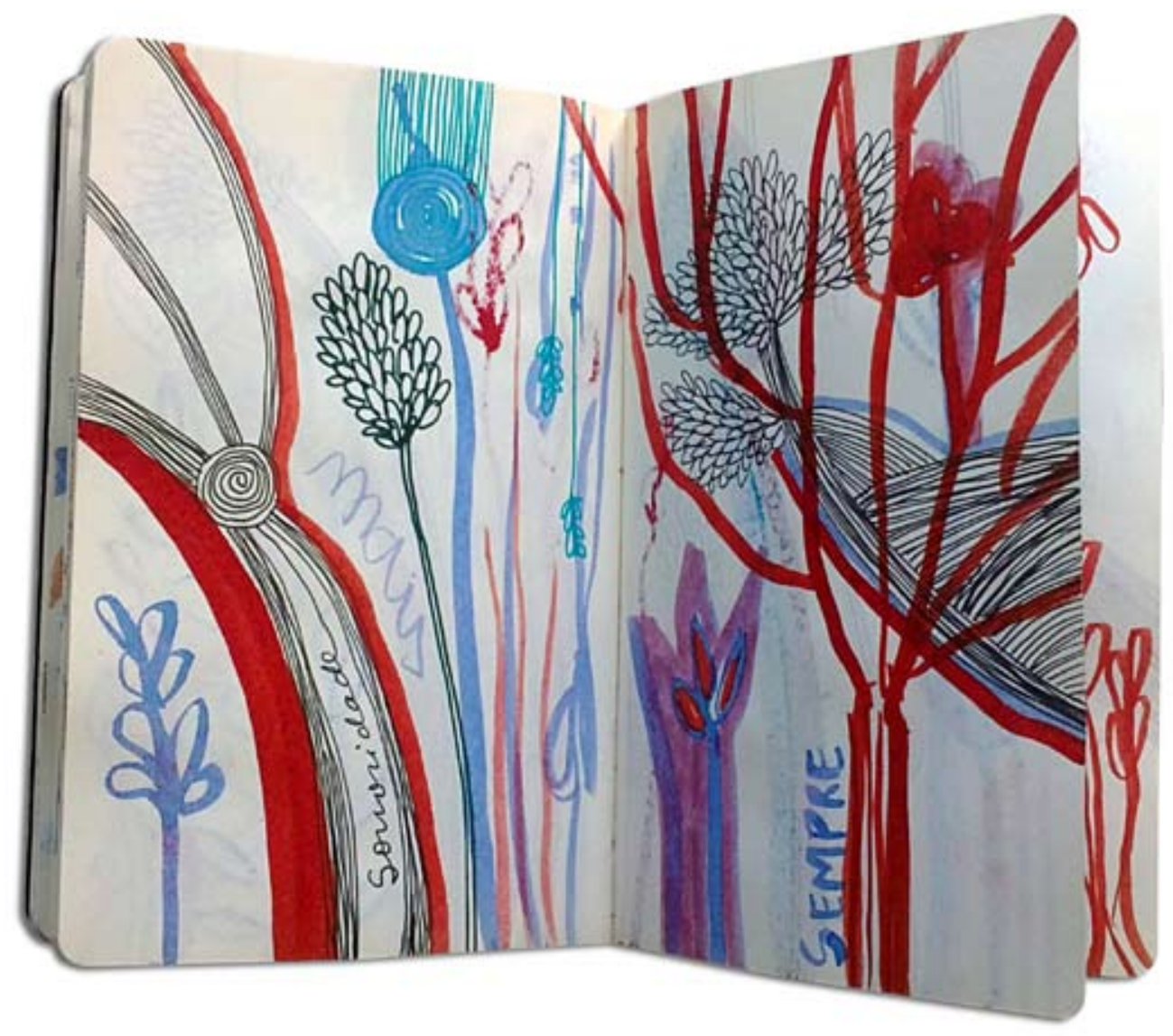




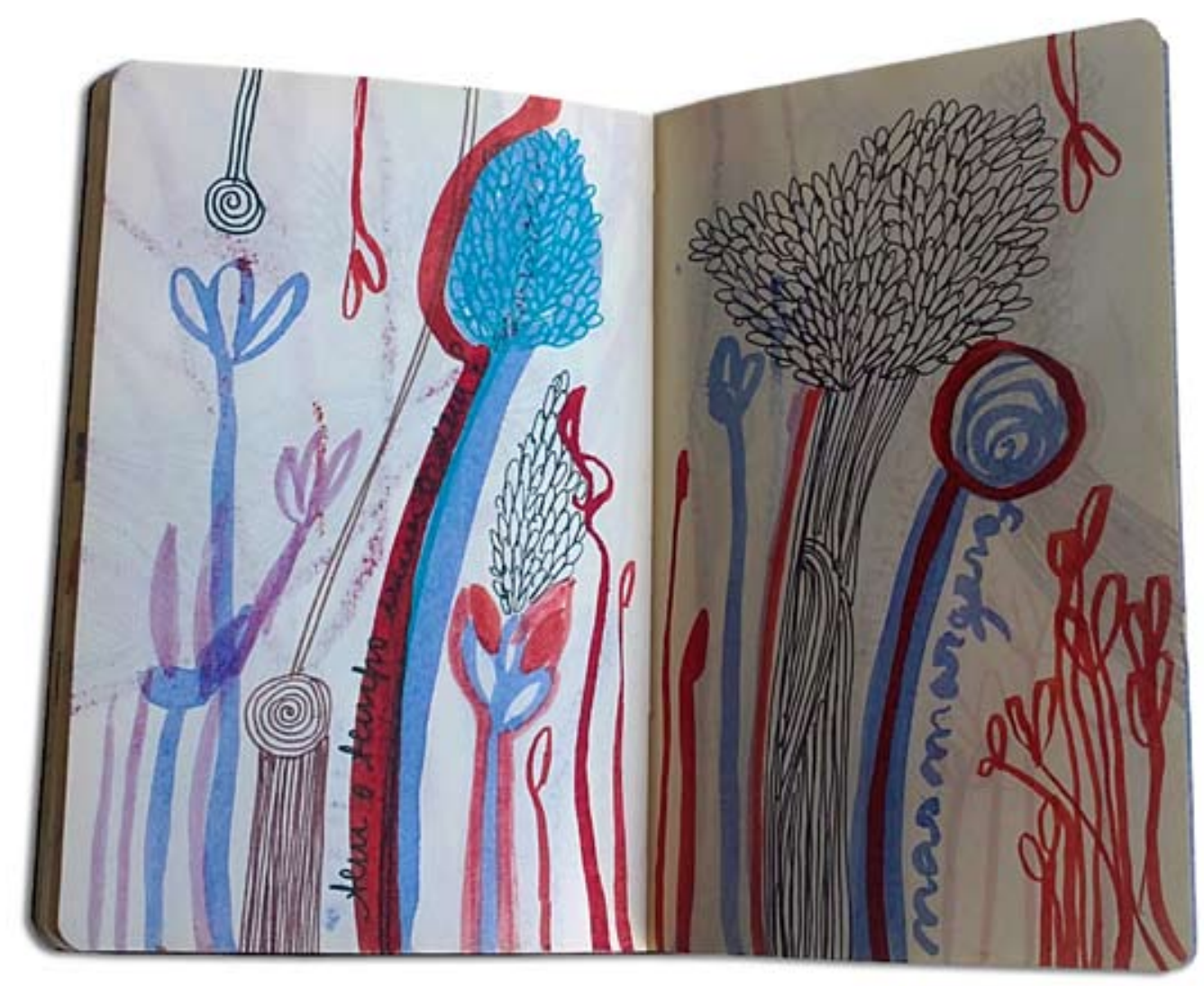




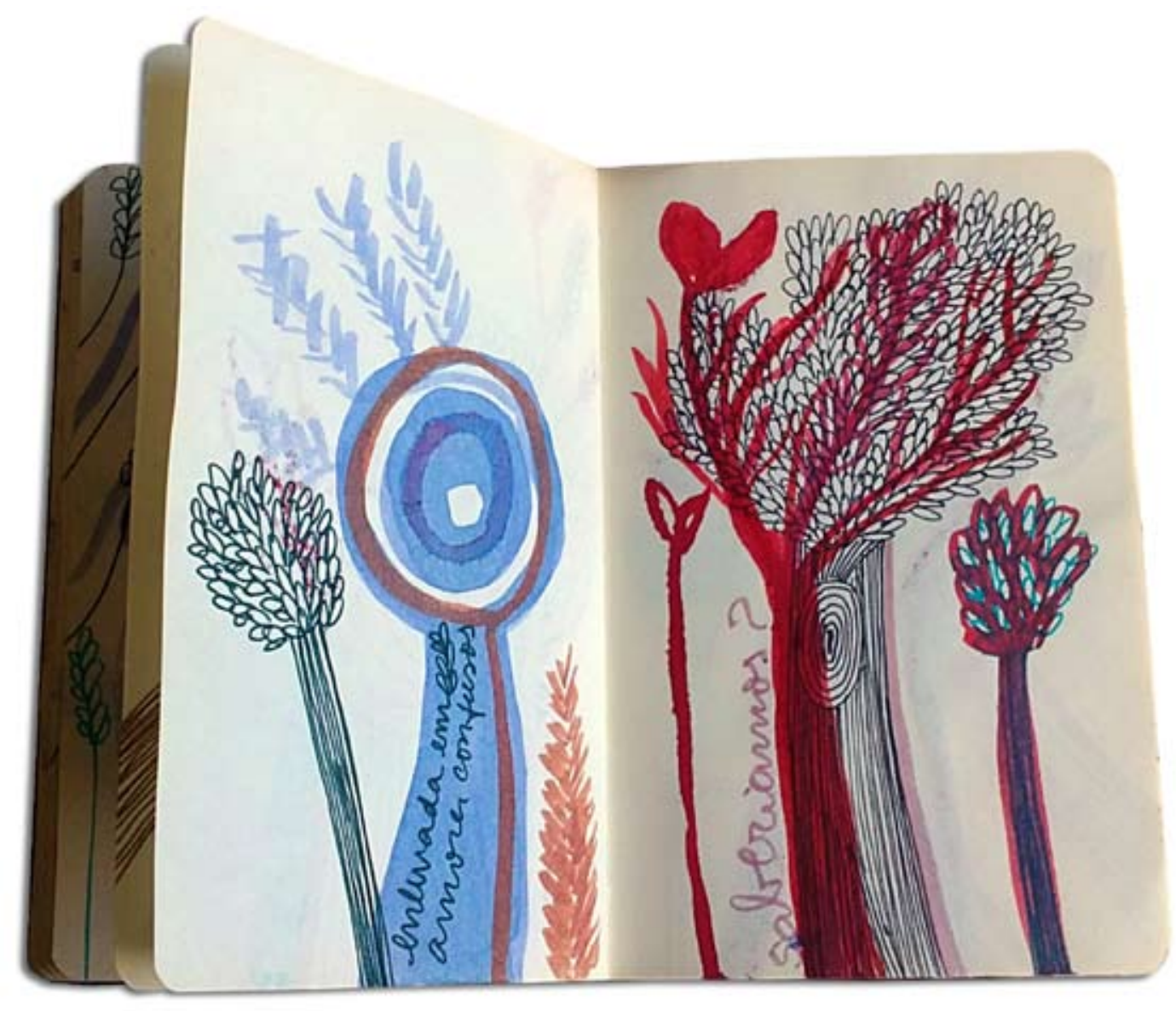


tempo é o pseudônimo de espera

a espera partiu-se na noite

nas árvores das casas brancas

e nas coisas impossíveis procuradas em vão,

nos sonhos que nos acompanham

a espera faz-se longa e esquecida

pergunta quem sou eu, não nos mares

mas em ti que habito a cada dia

eu que sinto excessivamente tudo

no meu coração sem sossego

há-de o mundo ter descanso 


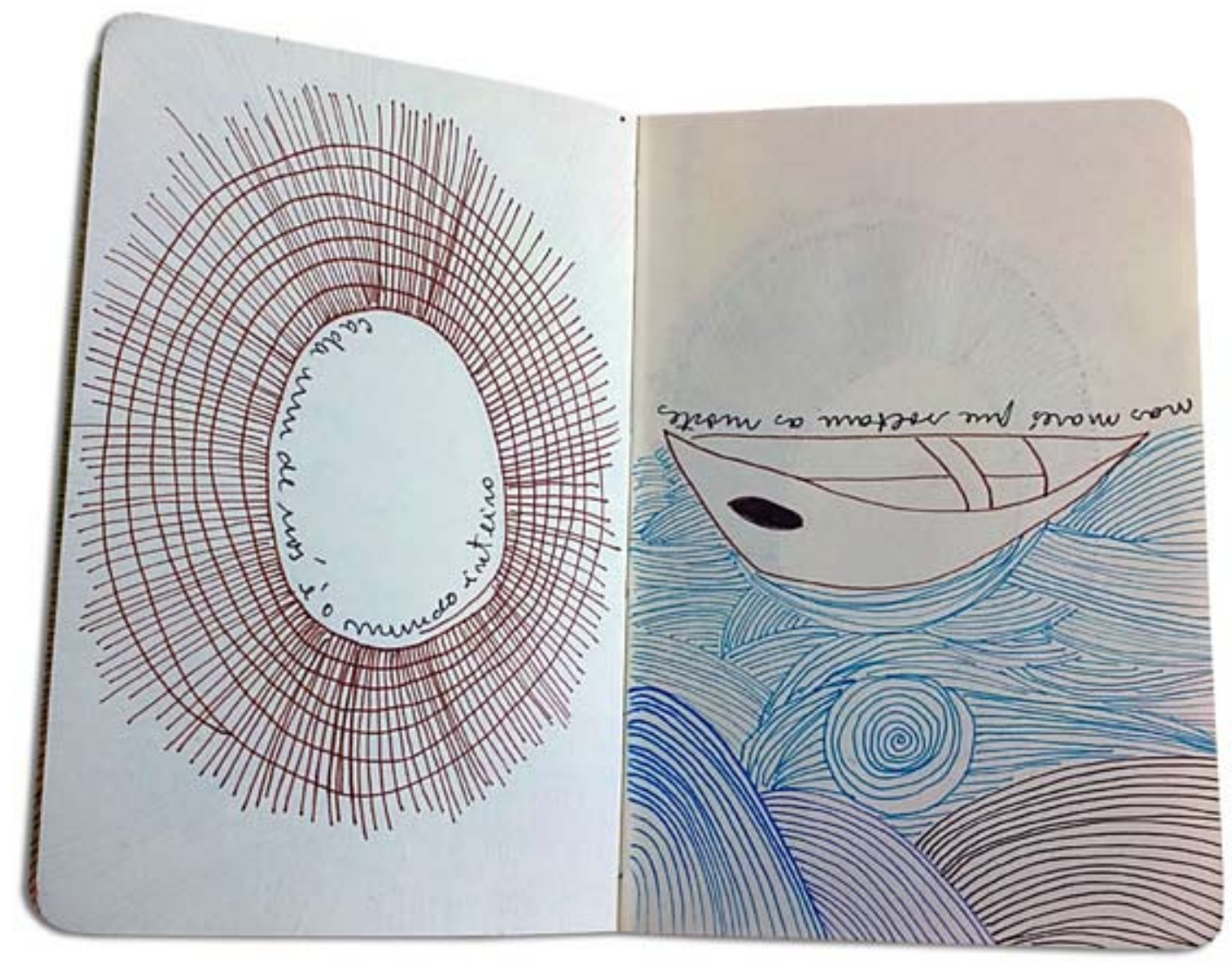




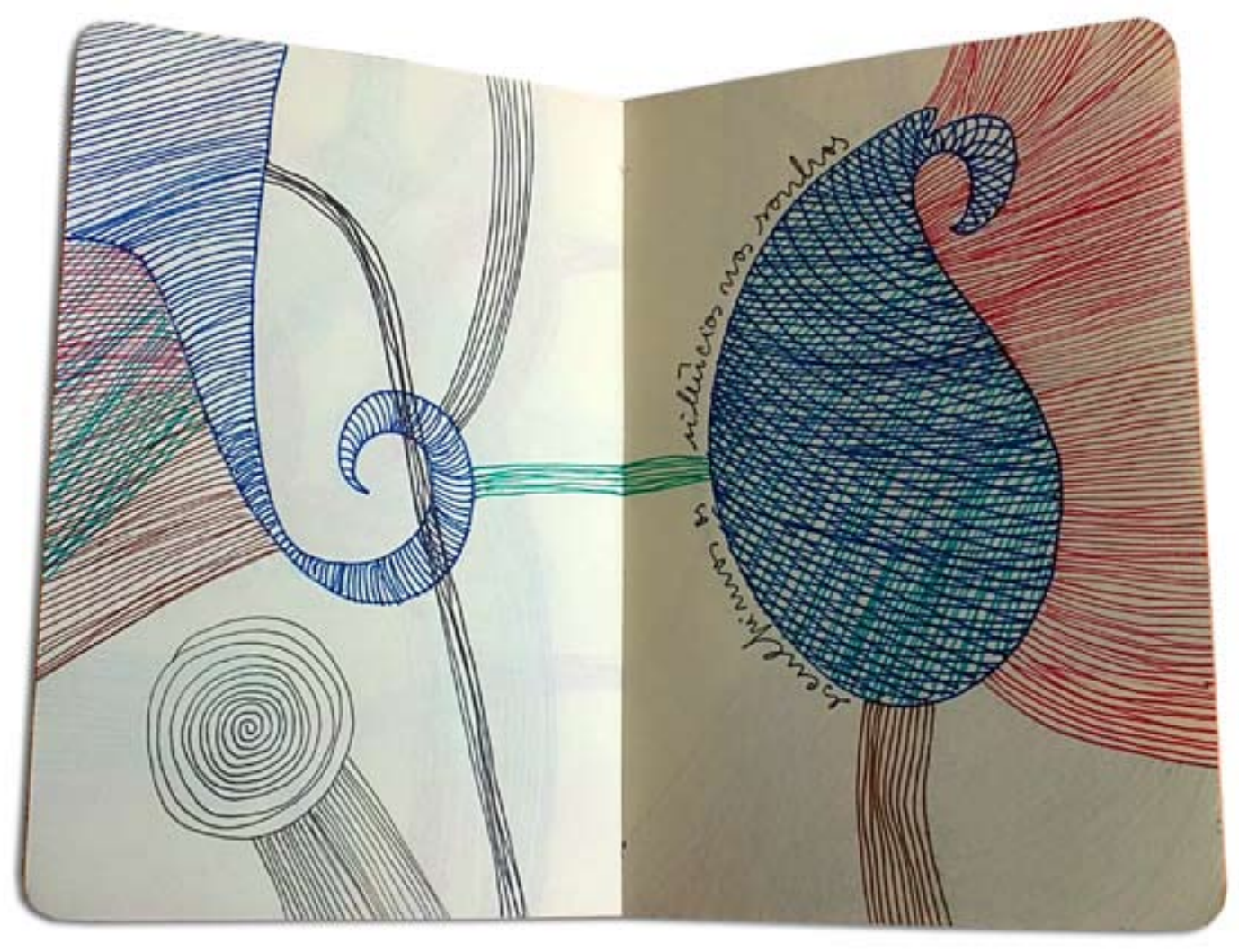




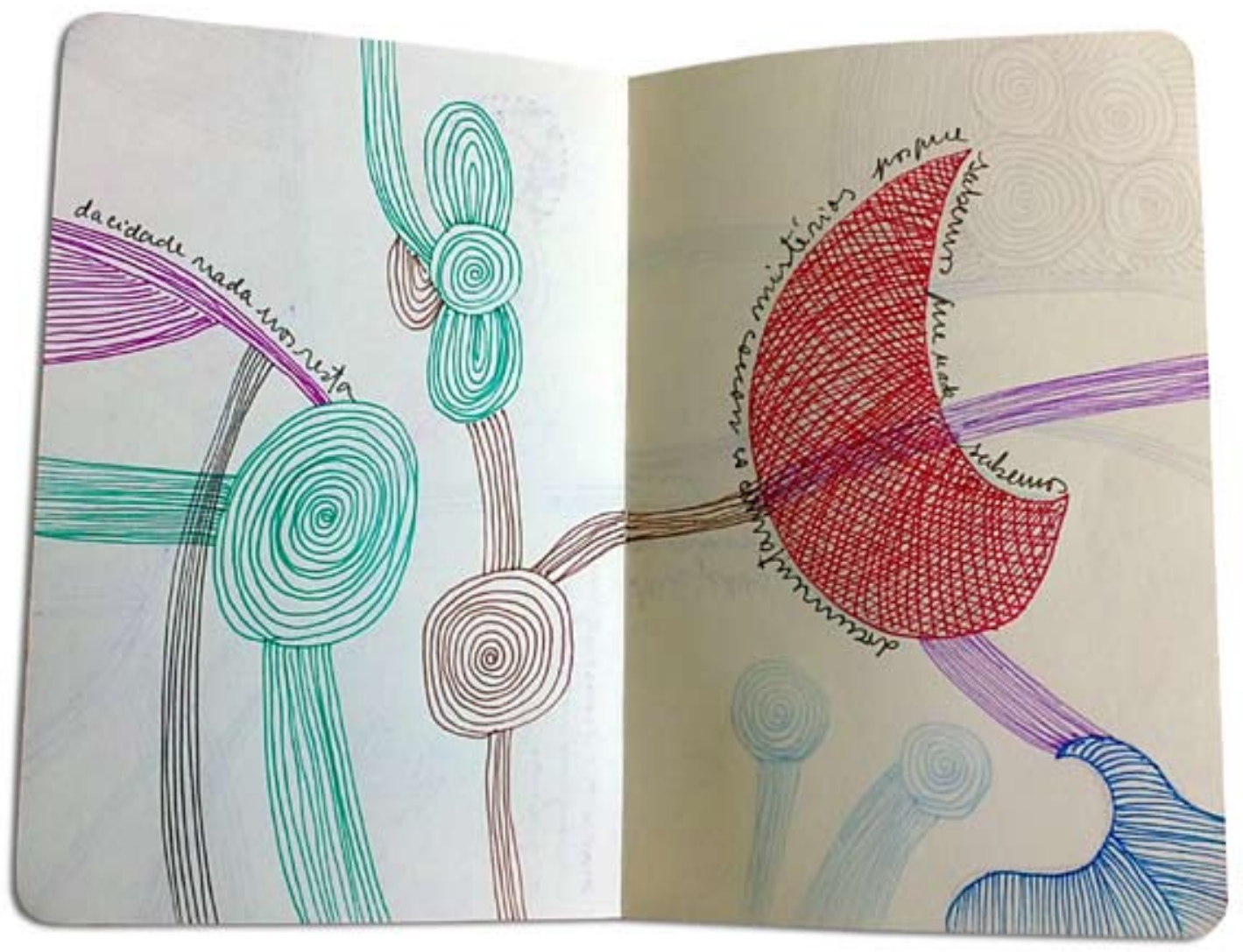


palavras se desenham

como se o mar fosse da praia,

nos sopros fugidios do sal

as cidades das nuvens

procuram caminhos 


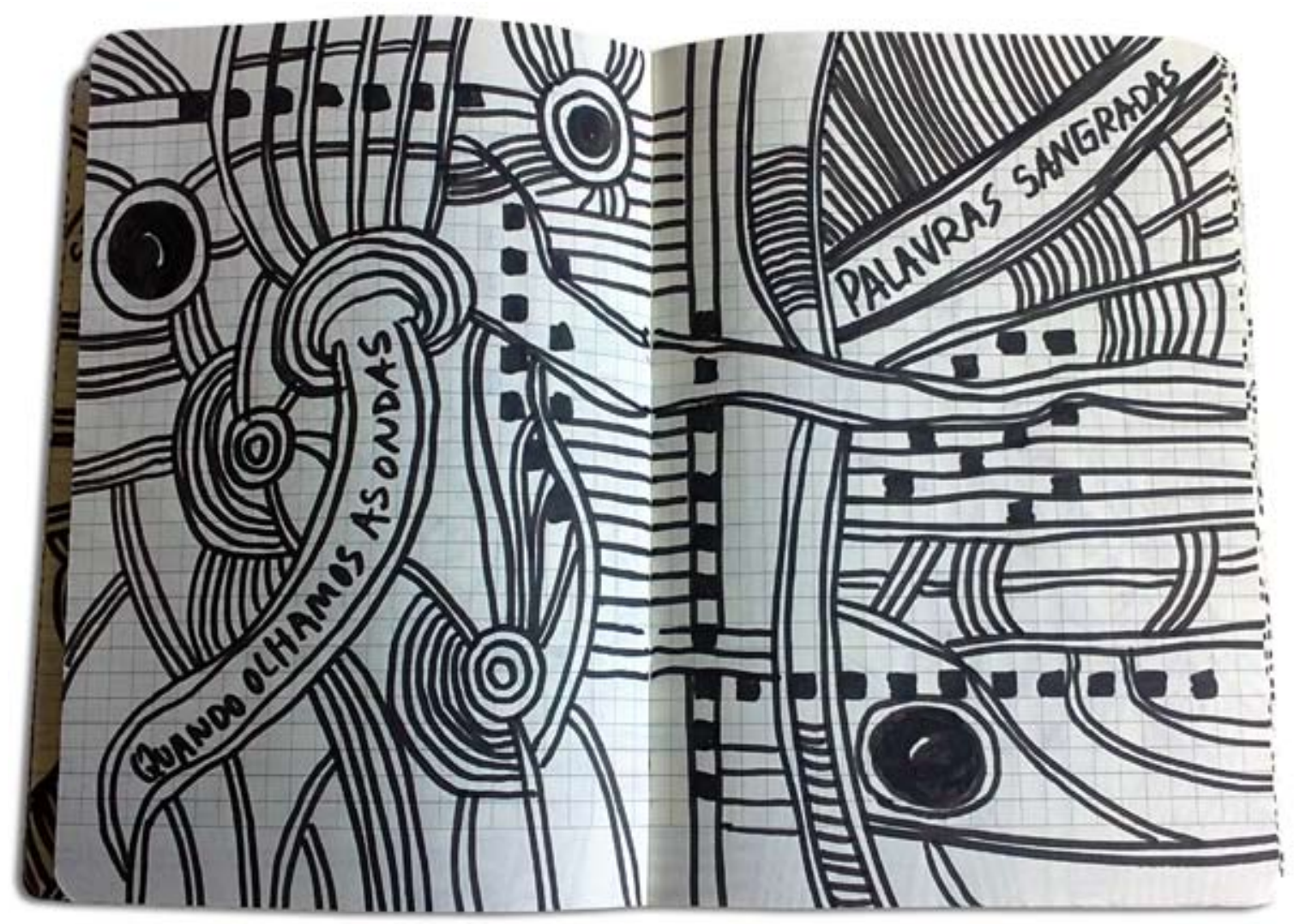




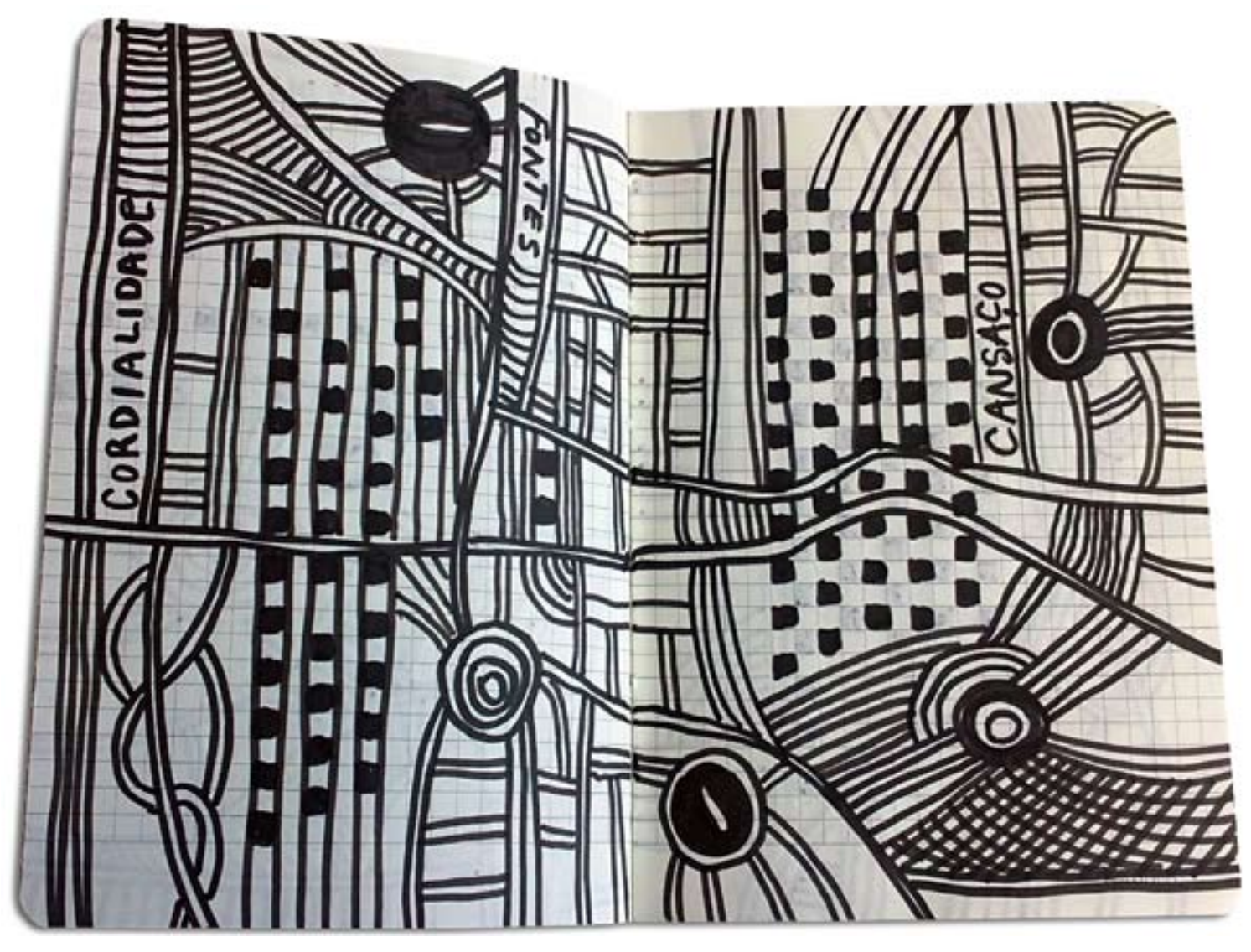




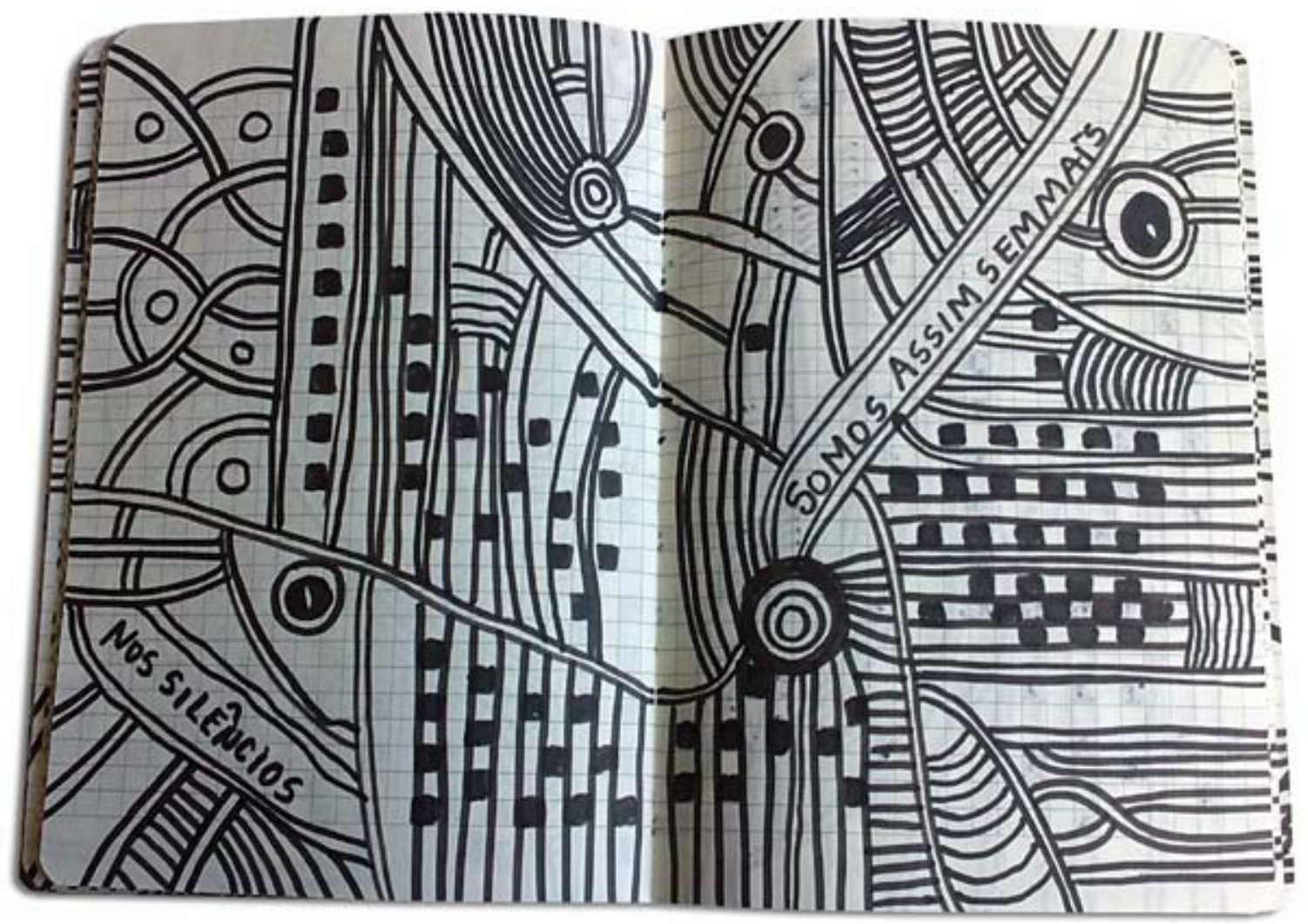


Onde as palavras nascem é segredo, não

têm morada fixa, existe uma linha imaginária entre o desenho de cada letra e os desejos.

Há palavras internas que cintilam nas almas,

navegam em ciclos, germinam no aprendizado dos silêncios perfumados pelas maresias e entendem limites através da linha desenhada. 


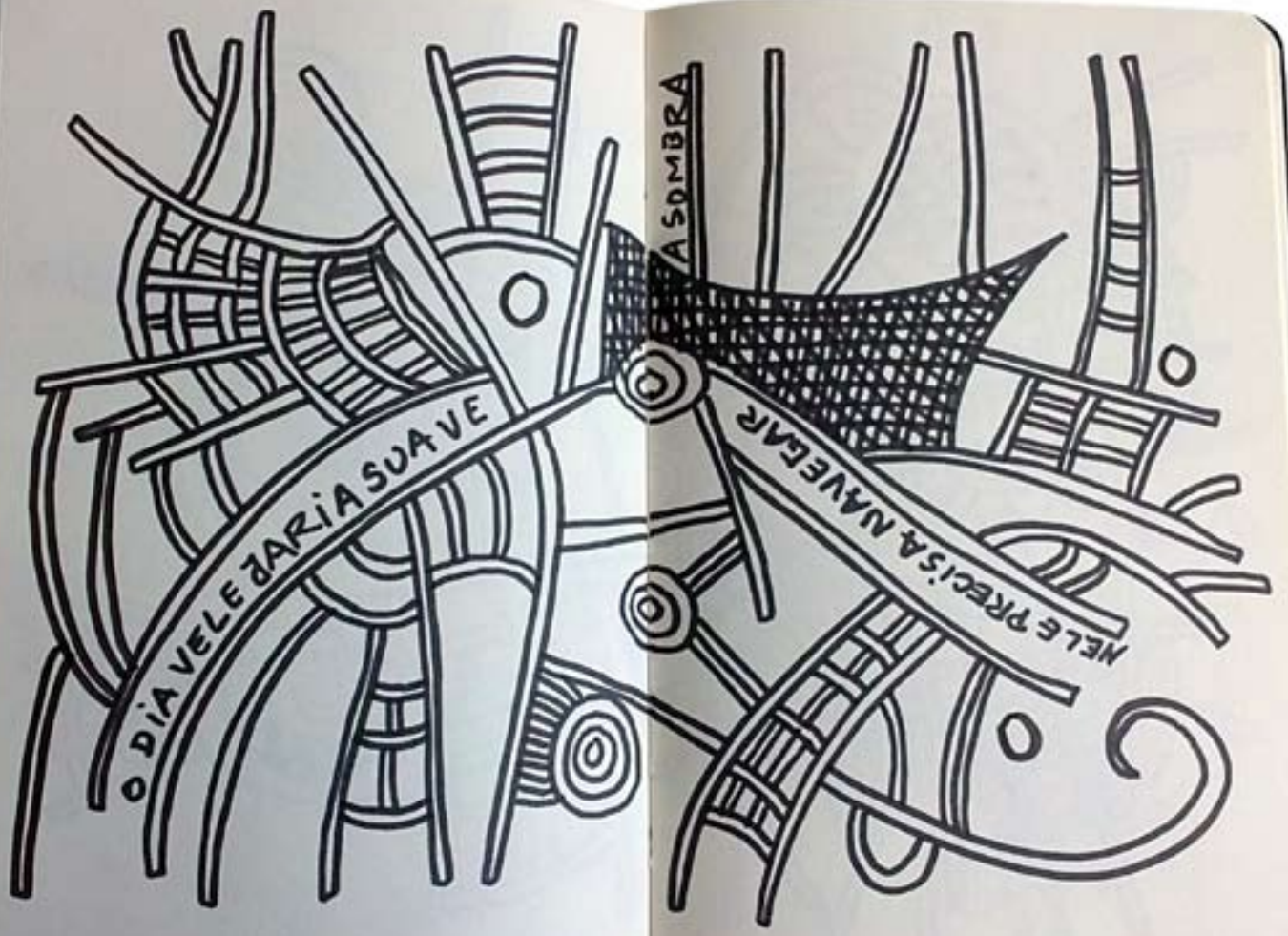





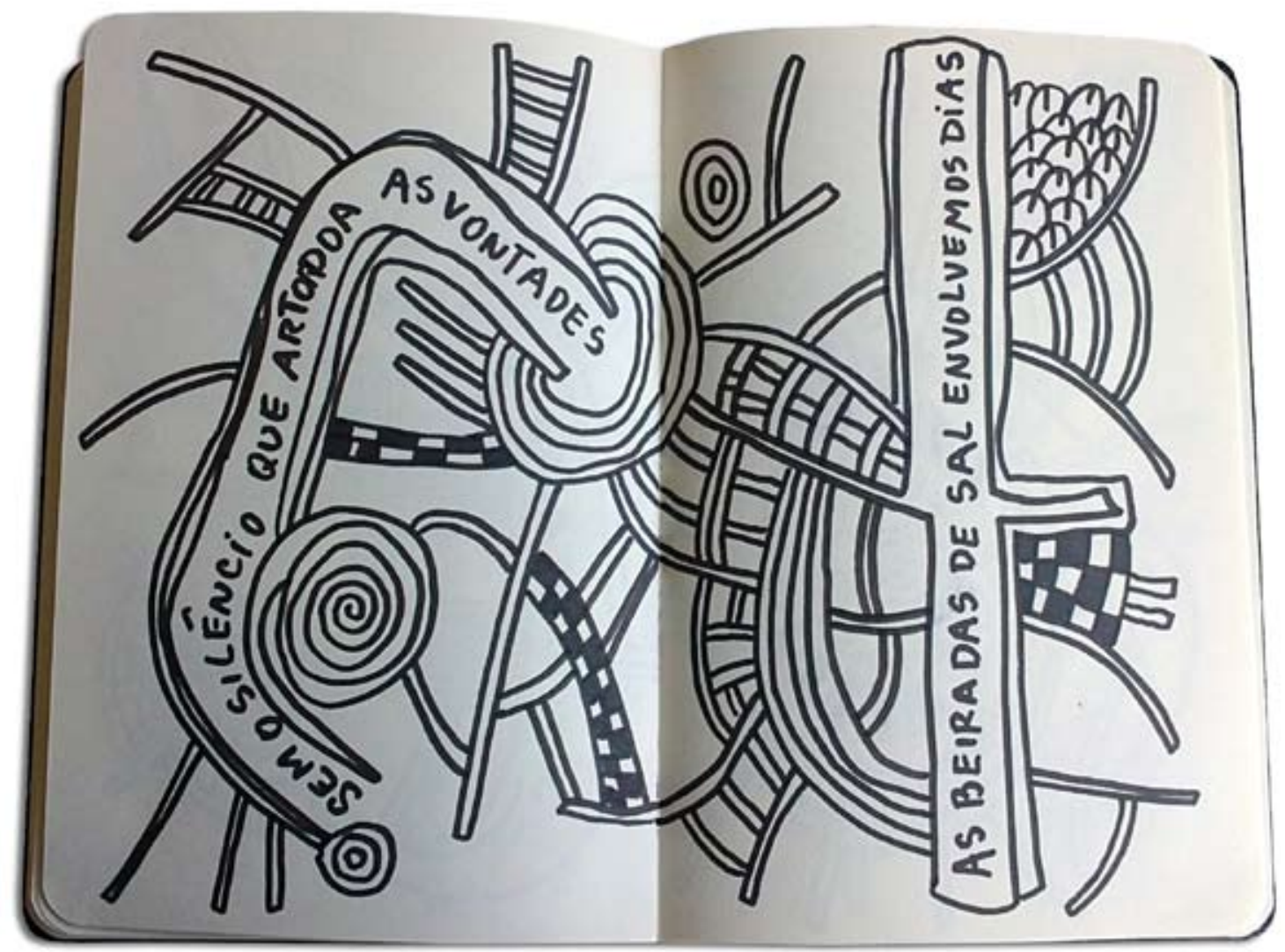




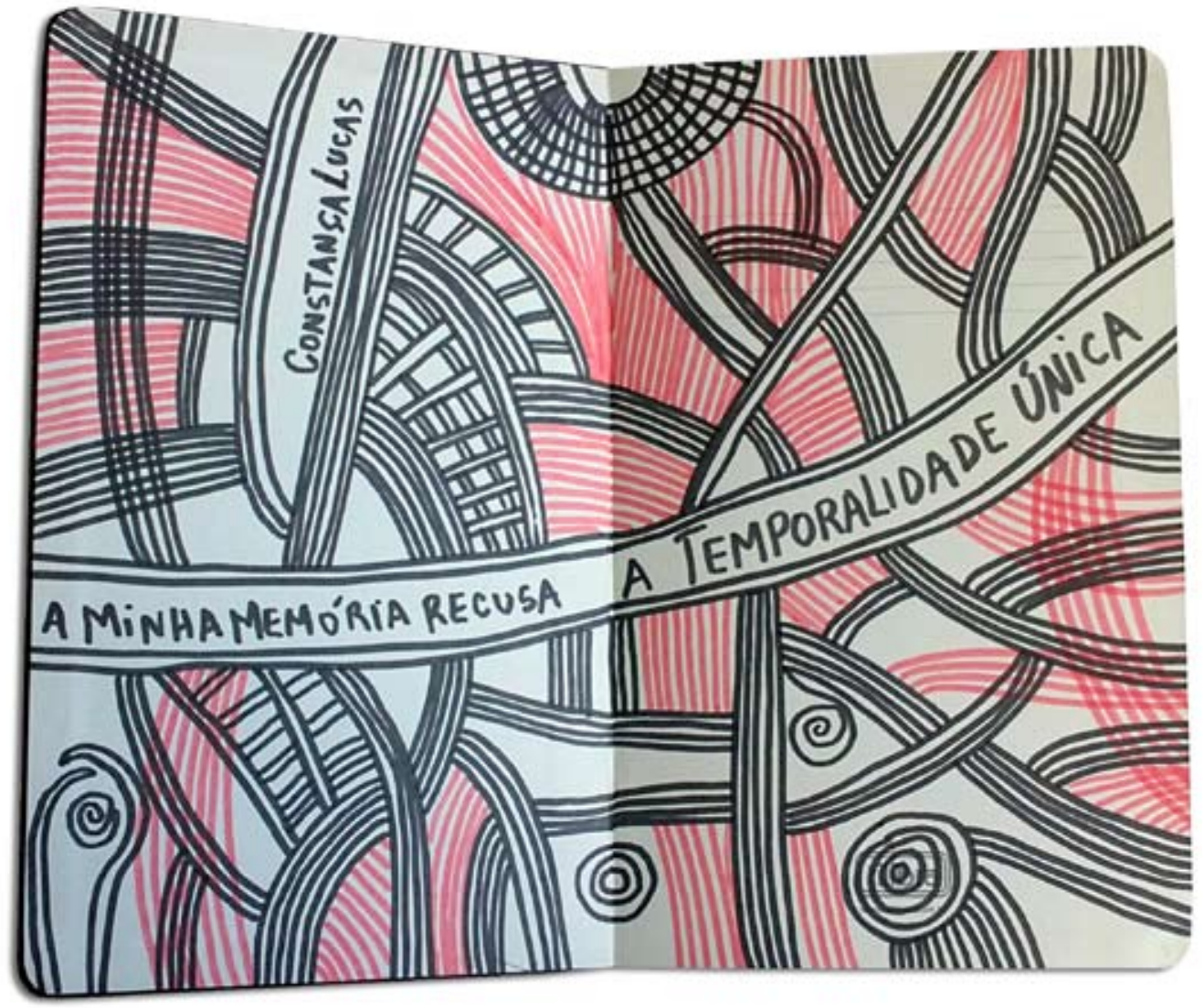




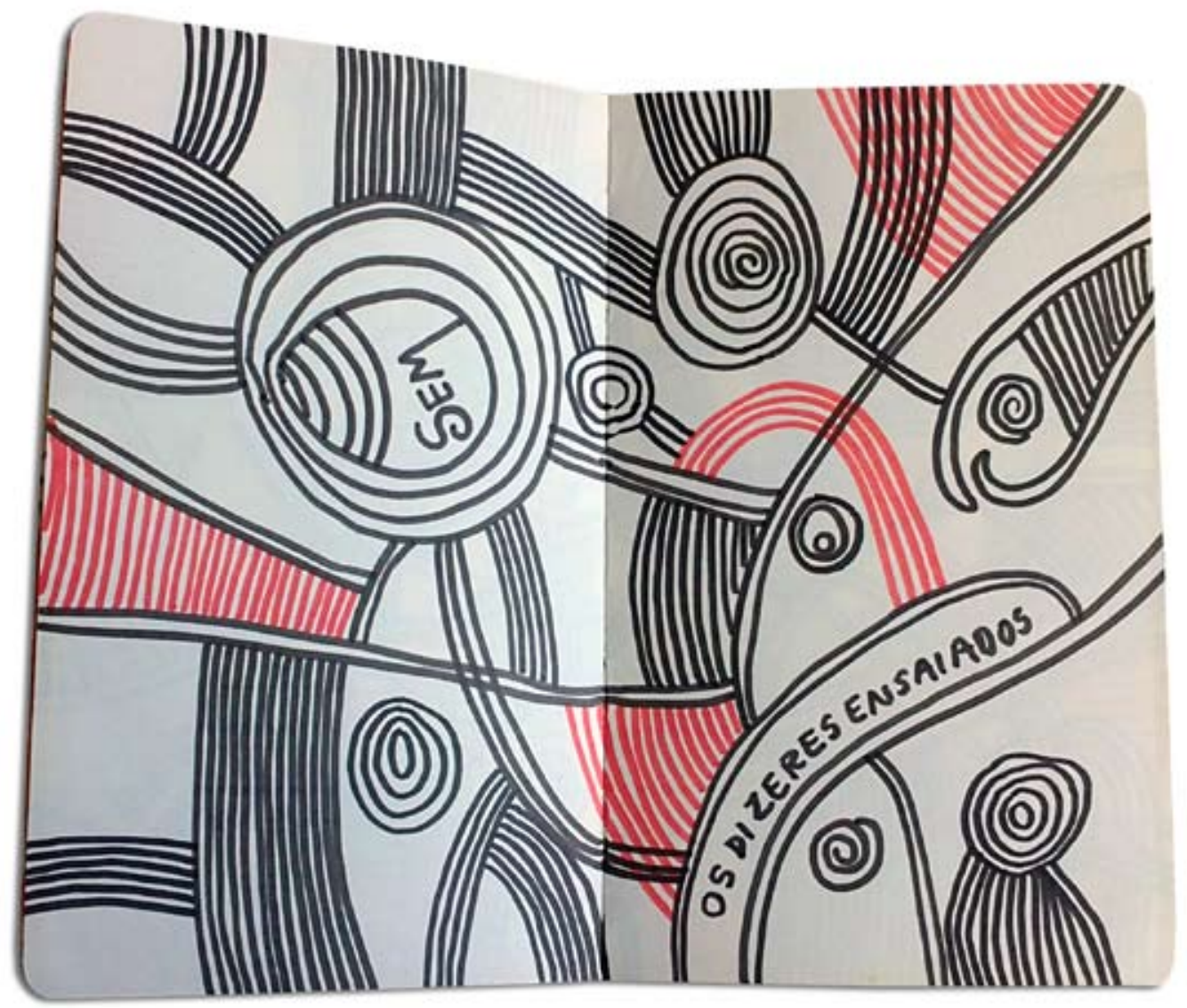




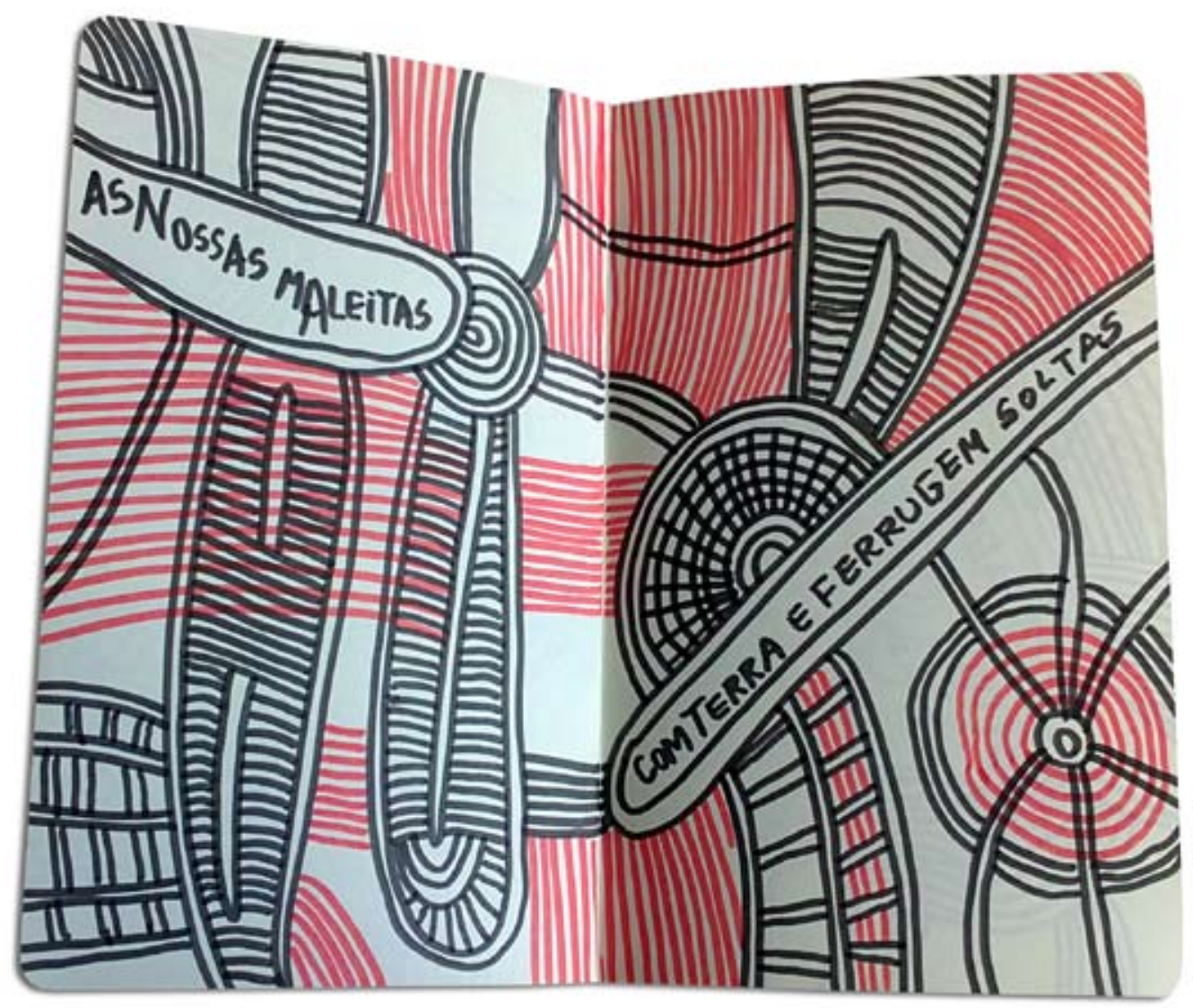





\section{Referências Bibliográficas}

\section{Livros:}

AGUIAR, Fernando. Tudo por tudo. São Paulo: Escrituras Editora, 2011.

. Maximino, Jorge. Imaginários de Rupturas e Poesia Experimental. Lisboa: Instituto Piaget, 2002.

AMARAL, Fernando Pinto do. Às Cegas. Lisboa: Relógio d'água, 1997

ANDRADE, Carlos Drummond de. Antologia Poética. Rio de Janeiro: Livraria José Olympio Editora, 1978.

. Corpo. Rio de Janeiro: Editora Record, 2011.

. Claro Enigma. São Paulo: Companhia das Letras, 2012.

ANDRADE, Eugénio de. O Outro Nome da Terra. Porto: Editora Limiar, 1988.

ANDRESEN, Sophia de Mello Breyner. Poemas Escolhidos. São Paulo: Companhia das Letras, 2004.

Dual. Lisboa: Moraes Editores, 1977.

ANTONIO, Jorge Luiz. Poesia Digital: teoria, história, antologias. São Paulo: Fapesp e

Editora Navegar, 2010

ANTUNES, Arnaldo. As coisas. São Paulo: Editora lluminuras, 2002.

. n.d.a. São Paulo: Editora lluminuras, 2010.

ARGAN, G. C. Arte Moderna. São Paulo: Companhia das Letras, 1992.

APOLLINAIRE, Guillaume. Caligramas. São Paulo: Ateliê Editorial, 2008.

BARBOSA, Ana Mae (Org.). Arte/Educação Contemporânea - Consonâncias Internacionais. São Paulo: Cortez Editora, 2008.

. AMARAL, Lilian. Interterritorialidade, mídias contextos e educação. São Paulo:

Editora SENAC e Edições SESC 2008.

BELO, Ruy. A Margem da Alegria. Lisboa: Moraes Editores, 1974.

BERTO, Al. O Medo trabalho poético 1974-1986. Lisboa: Contexto, 1987.

BARROS, Manoel de. Livro Sobre Nada. Rio de Janeiro: Editora Record, 2001.

Ensaios fotográficos. Rio de Janeiro: Editora Record, 2007.

BORGES, Jorge Luis. Esse Ofício do Verso. São Paulo: Companhia das Letras, 2000. 
. Elogio da Sombra. Rio de Janeiro: Editora Globo, 2001.

. SABATO, Ernesto. Diálogos, São Paulo: Editora Globo, 2005.

BOSI, Alfredo. O Ser e o Tempo da Poesia. São Paulo: Cia das Letras. 2000.

BRASSAÏ. Conversas com Picasso. São Paulo: Cosac Naify, 2000.

BRITTO, Paulo Henriques. Formas do Nada. São Paulo: Companhia das Letras, 2012.

BROSSA, Joan. Poesia Vista. São Paulo: Ateliê Editorial/Amauta Editorial, 2005.

CALVINO, Italo. Seis Propostas para o próximo milénio. Lisboa: Teorema, 1990.

CAMARGO, Iberê. Gaveta dos Guardados. São Paulo: EDUSP, 1998.

CASTRO, E. M de Melo; Nádia Battella Gotlib (Org). O fim visual do século XX e outros textos críticos. Sã Paulo: Edusp, 1993.

CAUQUELIN, Anne. Arte Contemporânea. São Paulo: Martins Fontes, 2005. . A Invenção da Paisagem. São Paulo: Martins Fontes, 2007.

CÉSAR, Ana Cristina. A Teus Pés. São Paulo: Editora Ática, 1999.

CHARTIER, Roger. Os desafios da Escrita. São Paulo: Editora Unesp, 2002. A aventura do livro do leitor ao navegador. São Paulo: Editora Unesp, 2002.

CRUZ, Gastão. A moeda do tempo e outros poemas. Rio de Janeiro: Língua Geral Livros, 2009.

CUMMINGS, e.e. xix poemas. Lisboa: Assírio \&Alvim, 1991.

DEXTER, Emma. Vitamin D: New Perspectives in Drawing. London: Phaidon, 2005.

DIAS, Geraldo Souza. Mira Schendel - do espiritual à corporeidade. São Paulo: Cosac Naify, 2009.

DICKINSON, Emily. Uma centena de poemas. São Paulo: T.A. Queiroz Editor/ EDUSP, 1985.

DONDIS, Donis A. Sintaxe da Linguagem Visual. São Paulo: Martins Fontes, 2003.

ECO, Humberto. Construir inimigos e outros escritos. Lisboa: Gradiva 2011.

. CARRIÉRE, Jean-Claude. Não contem com o fim do livro. Rio de Janeiro: Editora

Record, 2001.

FARIA, Maria Isabel; PERICÃO, Maria da Graça. Dicionário do Livro - Da escrita ao livro eletrônico. São Paulo: Edusp, 2008.

FERREIRA, Glória; COTRIM, Cecilia. Escritos de Artistas anos 60/70. Rio de Janeiro: Zahar, 2009. FERREIRA, Orlando da Costa. Imagem e Letra. São Paulo: Edusp, 1994. 
FIGUERES, Josep M.; SEABRA, Manuel de. Antologia da Poesia Visual Européia. Lisboa:

Editorial Futura, 1977.

FILIPE, Daniel. Pátria lugar de exílio. Lisboa: Editorial Presença, 1977.

FOCILLON, Henri. A vida das formas. Lisboa: Edições 70, 2001.

GEDEÃO, António. Poesias Completas (1956-1967). Lisboa: Portugália Editora, 1975.

GENET, Jean. 0 ateliê de Giacometti. São Paulo: Cosac Naify, 2000.

GIL, José. Sem título: escritos sobre arte e artistas. Lisboa: Relógio d'água, 2005.

GULLAR, Ferreira. Em alguma parte alguma. Rio de Janeiro: José Olympio, 2010

HATHERLY, Ana. A Casa das Musas. Lisboa: Editorial Estampa, 1995.

. A ldade da Escrita. São Paulo: Escrituras Editora, 2005.

HELDER, Herberto. Última Ciência. Lisboa: Assírio e Alvim. 1988.

A cabeça entre as mãos. Lisboa: Assírio e Alvim. 1982.

HIGOUNET, Charles. História Concisa da escrita. São Paulo: Parábola Editorial, 2003.

JEAN, Georges. A Escrita Memória dos Homens. Rio de Janeiro: Editora Objetiva, 2002.

JORGE, Luiza Neto. Corpo insurrecto e outros poemas. São Paulo: Escrituras Editora, 2008.

JÚDICE, Nuno. Por dentro do fruto a chuva. São Paulo: Escrituras Editora, 2004.

KAVAFIS, Konstantinos. 25 Poemas. Lisboa: Edições Cotovia, 1988.

KLEE, Paul. Sobre a arte moderna. Rio de Janeiro: Jorge Zahar Editor, 2001.

. Diários. São Paulo: Livraria Martins Fontes, 1990

LISPECTOR, Clarice. Aprendendo a viver. Rio de janeiro: Editora Rocco, 2004.

LOURENÇO, Eduardo. A Nau de Ícaro. São Paulo: Companhia das Letras, 2001.

LUPTON, Ellen. Pensar com tipos. São Paulo: Cosac \& Naify, 2008.

MAN, John. A História do Alfabeto. São Paulo: Ediouro, 2001.

MATISSE, Henri. Escritos e Reflexões sobre Arte. Lisboa: Editora Ulisseia,1972.

MEGGS, Philip B. História do Design Gráfico. São Paulo: Cosac Naify, 2009.

MEIRELES, Cecília. Mar Absoluto / Retrato Natural. Rio de Janeiro: Editora Nova Fronteira, 1983.

MENEZES, Philadelpho. Poesia Concreta e Visual. São Paulo: Editora Ática, 1998.

MOLINA, José Gómez. Las lecciones del Dibujo. Madrid: 2003. 
NETO, João Cabral de Melo. O cão sem plumas. Rio de Janeiro: Editora Objetiva, 2007. O'NEIL, Alexandre. Poesias Completas 1951/1981. Lisboa: Imprensa Nacional-Casa da Moeda, 1982.

PACHECO, Fernando Assis. Respiração Assistida. Lisboa: Assírio \&Alvim, 2003.

PAdín, Clemente. La Poesia Es La Poesia. Buenos Aires: Ediciones Imaginarias, 2003.

PAIVA, Ana Paula Matias de. A aventura do Livro Experimental. São Paulo: Autêntica Editora e EDUSP, 2010.

PAMUK, Orhan. O romancista ingênuo e sentimental. São Paulo: Companhia das Letras, 2011 PAZ, Octavio. A Outra Voz. São Paulo: Editora Siciliano, 2001.

PAZ, Marie José. Figuras e Figurações. Lisboa: Assírio \&Alvim, 2000.

PEIXOTO, José Luís. Abraço. Lisboa: Quetzal, 2011.

. A criança em ruínas. Vila Nova de Famalicão: Edições Quase, 2003.

. Gaveta de Papéis.Lisboa: Quetzal, 2011.

PESSOA, Fernando. Livro do Desassossego. Volumes I e II. Lisboa: Edições Ática, 1997.

. Alberto Caeiro-Poemas Completos. São Paulo: Editora Saraiva, 2007.

PONTES, Hugo. Poemas Visuais e Poesias. São Paulo: Dix Editorial, 2007.

PRADO, Adélia. A Duração do dia. Rio de Janeiro: Editora Record, 2011.

READ, Herbert. As Origens da Forma de Arte. Rio de Janeiro, Zahar Editores, 1981.

ROSA, António Ramos. Clareiras. Lisboa: Ulmeiro, 1986.

. A Intacta ferida. Lisboa: Relógio de água, 1991.

. As Palavras. Porto: Capo das Letras, 2001.

ROSA, João Guimarães. Ave, Palavra. Rio de Janeiro: Livraria José Olympio Editora, 1978.

ROSÁRIO, Maria do. O canto do vento nos ciprestes. São Paulo: Escrituras Editora, 2008

SABATO, Ernesto. O escritor e seus fantasmas. São Paulo: Companhia das Letras, 2003.

SAID, Edward. Representações do Intelectual - As Conferências Reith de 1993. São Paulo:

Companhia das Letras, 1994.

Reflexões sobre o exílio e outros ensaios. São Paulo: Companhia das Letras, 2003. 
SALLES, Cecília Almeida. Gesto Inacabado - Processo de Criação Artística. São Paulo: Annablume, 2001.

Redes de Criação - Construção da obra de arte. Vinhedo: Editora Horizonte, 2006.

SALZSTEIN, Sônia (Org.). Matisse/ Imaginação, erotismo e visão decorativa. São Paulo:

Cosac Naify, 2009.

SANTOS, Milton. Pensando o espaço do Homem. São Paulo: EDUSP, 2004.

SARTRE, Jean-Paul. Alberto Giacometti. São Paulo: Wmf Martins Fontes 2012.

SENA, Jorge de. Exorcismos. Lisboa: Circulo de Poesia - Moraes Editores, 1972.

SILVEIRA, Paulo. A Página Virada - Da ternura à injúria na construção do livro de artista.

Porto Alegre: Editora da Universidade, 2001.

SENNETT, Richard. O Artífice. Rio de Janeiro: Record, 2009.

SONTAG, Susan. Diante da Dor dos Outros. São Paulo: Companhia das Letras, 2003.

STEINBERG, Leo. Outros Critérios. São Paulo: Cosac Naify, 2008.

VALÉRY, Paul. Degas Dança Desenho. São Paulo: Cosac Naify, 2003.

Variedades. Editora lluminuras, São Paulo, 1991.

WILKINSON, Alan. Henry Moore: Writings and Conversations. Los Angeles: University of

California Press, 2002

ZANINI, Walter (Org.). História Geral da Arte no Brasil. São Paulo: Instituto Walther Moreira

Salles - Fundação Djalma Guimarães, 1984.

\section{Catálogos}

FERNANDES, Maria João. Caligrafias - a nascente dos nomes. Lisboa: Fundação

Portuguesa de Comunicações, 2008.

MUBARAC, Claudio. O desenho estampado a obra gráfica de Evandro Carlos Jardim. São Paulo: Pinacoteca do Estado de São Paulo, 2005.

PÉREZ-Oramas, Luís. León Ferrari; Mira Schendel - o alfabeto enfurecido. Porto Alegre:

Fundação Iberê Camargo, 2010.

WIESINGER, Véronique. Giacometti. São Paulo: Cosac Naify, 2012. 


\section{Documentos eletrônicos consultados}

\section{Sites e Blogs}

Antologia Boek Visual: http://boek861.blog.com.es/

Artes Postal e poesia visual - Saudarte: http://webs.uvigo.es/saudarte/

Biblioteca Nacional de Portugal: http://www.bnportugal.pt/

Brazilian Digital Art and Poetry on the Web: http://www.vispo.com/misc/BrazilianDigitalPoetry.htm

Centro de Documentación de Poesía Visual de Espana: http://centrodepoesiavisual.blogspot.com/

Cronópios - portal de literatura e arte: http://www.cronopios.com.br/site/poesia.asp?id=4735

Germina revista :http://www.germinaliteratura.com.br/constanca_lucas.htm

Jornal de Poesia: http://www.jornaldepoesia.jor.br/poesia.html

Mostra Internacional de Poesia Visual e Eletrônica:

http://arteonline.arq.br/museu/library_pdf/mostra_poesia.html

Mostra Internacional de Poesia Visual 13 de junho a 08 de julho de 2005:

http://www.iar.unicamp.br/alunos/poesiavisual/inicial.html

Multiplicidades: http://www.multiplicidades.art.br/

Poema Visual: http://www.poemavisual.com.br/

Poesía visual contra violencia de gênero: http://pvcontravg.blogspot.com/

Portal de Poesia Ibero America: http://www.antoniomiranda.com.br/index.html

Tanto: http://www.tanto.com.br/opoemavisual.htm

Vídeo com Poemas visuais de Constança Lucas realizado por Boek 861 / Espanha:

https://www.youtube.com/watch?v=ensBLhPJTvQ\&feature=player_embedded

\section{Site e Blogs de Constança Lucas}

Constança Lucas : http://www.constanca.lucas.nom.br/

Imagem e Palavra: http://www.constancalucas.blogspot.com.br/

Projeto: Postais com Poemas Visuais: http://postaiscompoemasvisuais.blogspot.com.br/

Poemas Visuais de Constança Lucas no Metrô de São Paulo:

http://poemasvisuaisnometrosp.blogspot.com/

Arte Postal Pela Paz: http://artepostalpelapaz.blogspot.com/

Arte postal - Os Livros: http://artepostaloslivros.blogspot.com/ 


\section{Índice das Obras}

\section{Poemas Visuais}

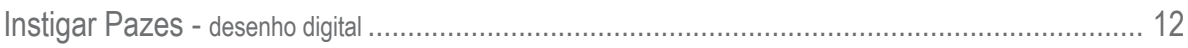

Poesia Use várias vezes ao dia - desenho digital ........................................................................ 13

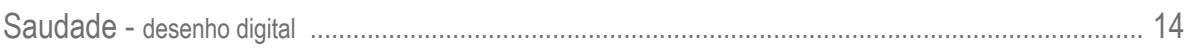

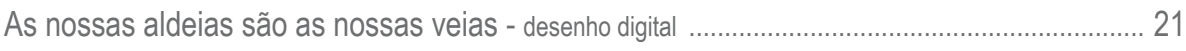

Caixinha de Palavras - desenho digital ............................................................................................. 22

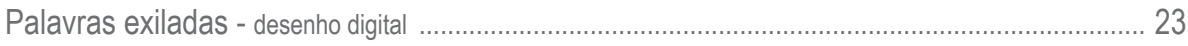

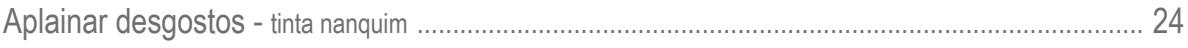

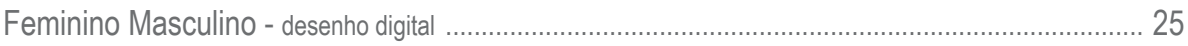

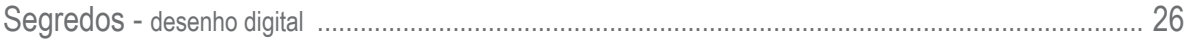

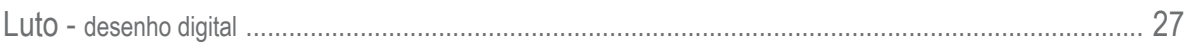

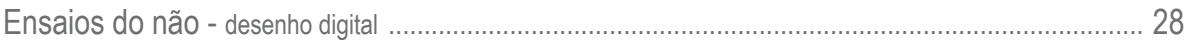

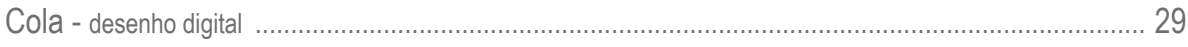

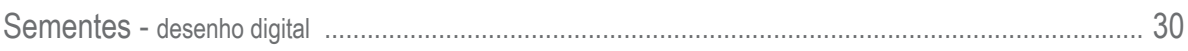

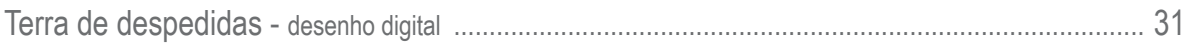

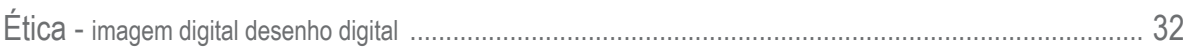

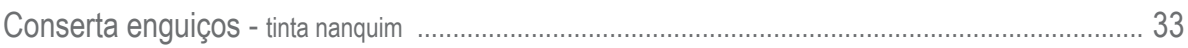

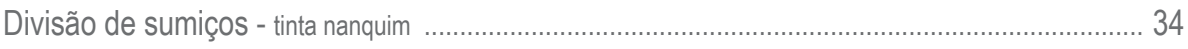

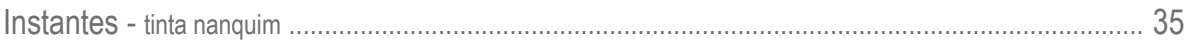

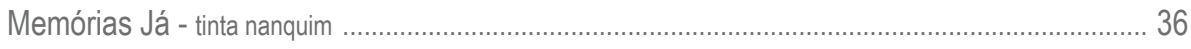

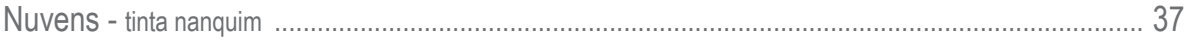

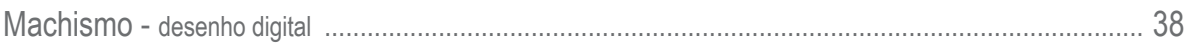

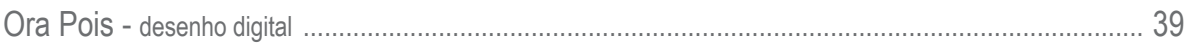

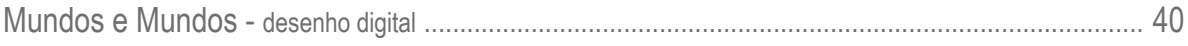

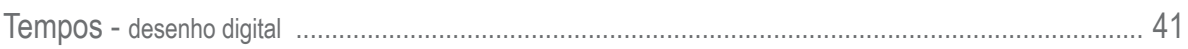

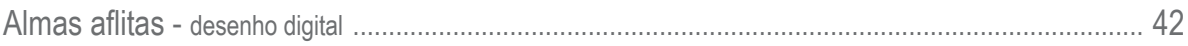

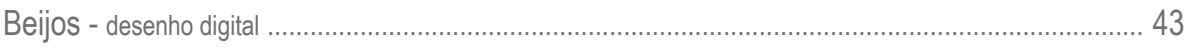

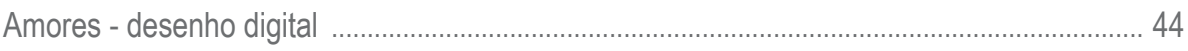

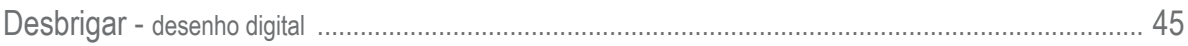

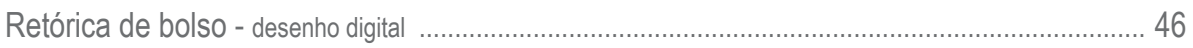

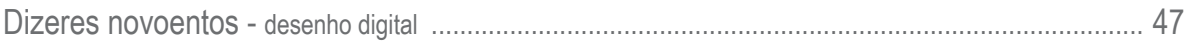

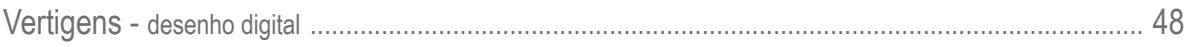

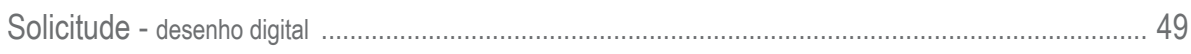




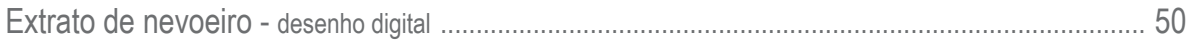

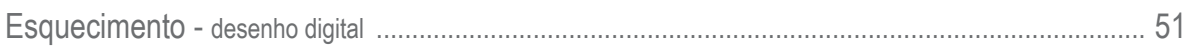

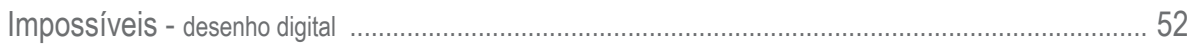

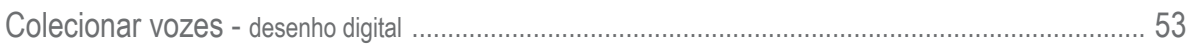

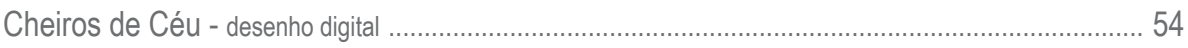

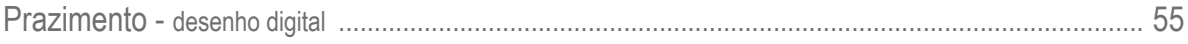

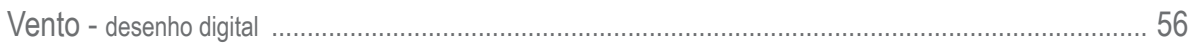

Projeto: Postais com Poemas Visuais

$2009 / 2012$ - 42 poemas visuais - $14 \mathrm{~cm} \times 10 \mathrm{~cm}$

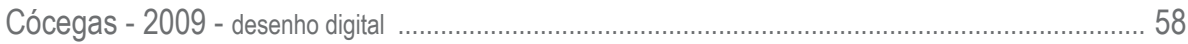

O tempo é pseudónimo de espera - 2009 - desenho digital ......................................................... 59

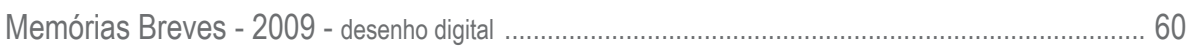

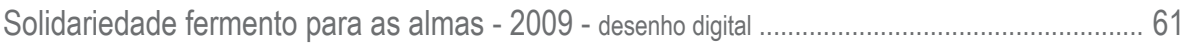

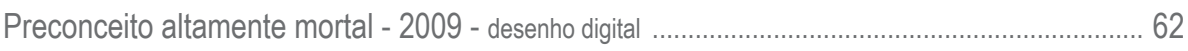

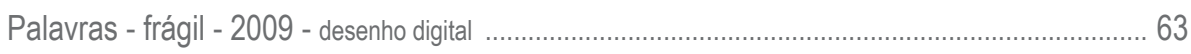

Sampa \& Lx - tinta permanente ideias passageiras - 2009 - desenho digital ................................... 64

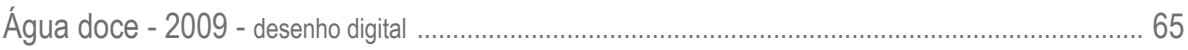

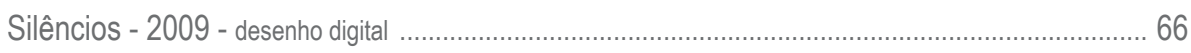

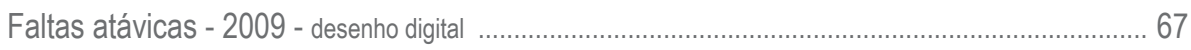

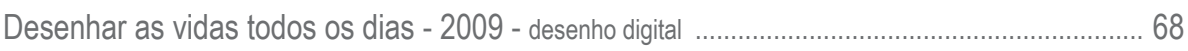

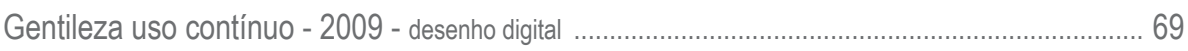

Sorrisos - uso facultativo - 2010 - desenho digital ..................................................................... 70

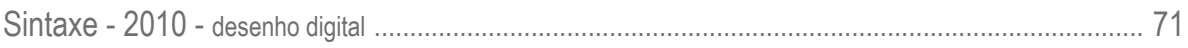

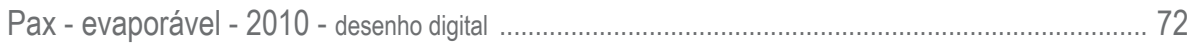

Repentes - uso esporádico - 2010 - desenho digital ......................................................................... 73

Vislumbres - realidade - 2010 - desenho digital ......................................................................... 74

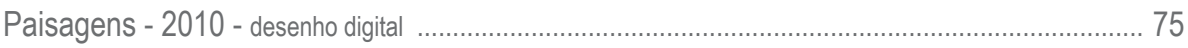

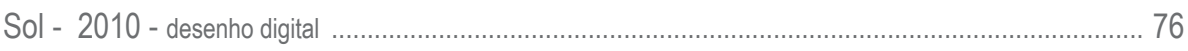

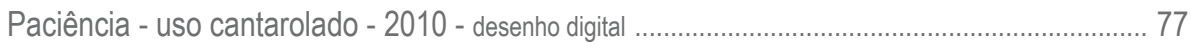

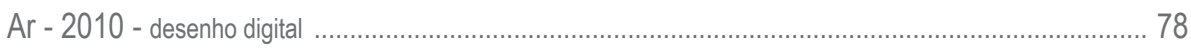

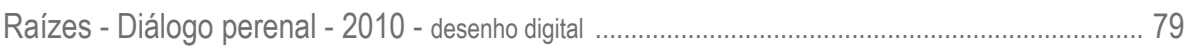

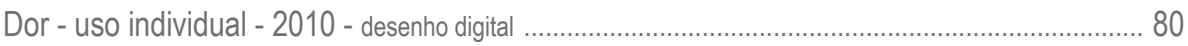

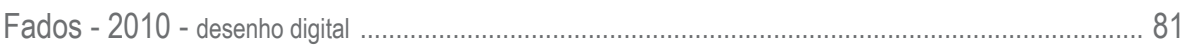

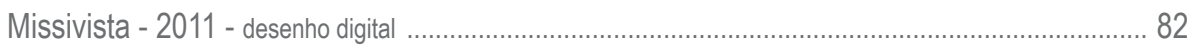

Precisão não é preciso - 2011 - desenho digital ........................................................................... 83

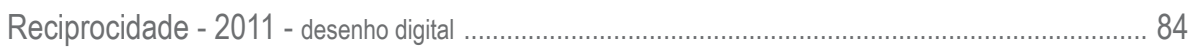




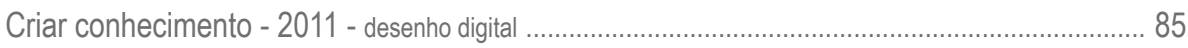

Afetos de transumância - 2011 - desenho digital ............................................................................ 86

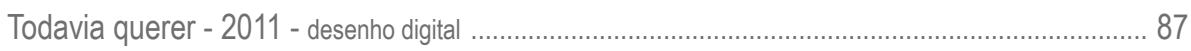

Fazes falta - 2011 - desenho digital ......................................................................................... 88

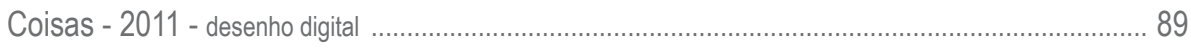

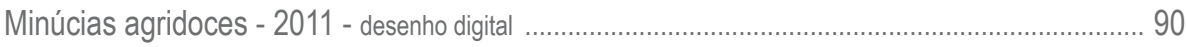

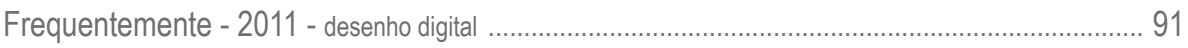

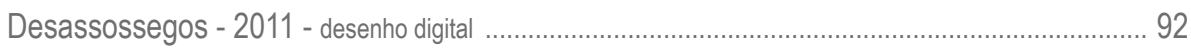

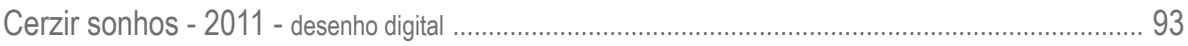

Alinhavos crispados para tardes chuvosas - 2012 - desenho digital .............................................. 94

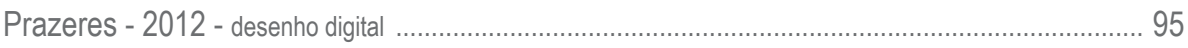

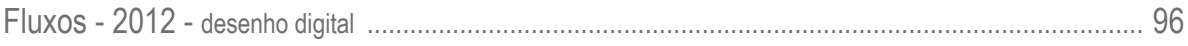

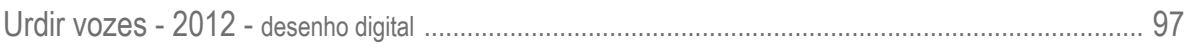

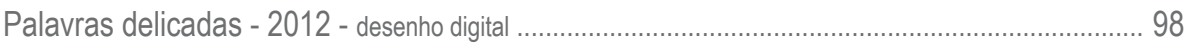

Entoar memórias para esquecer esquecimentos - 2012 - desenho digital ...................................... 99

Óleo para maquinetas estreladas - 2012 - desenho digital ............................................................. 100

\section{Caminhos Urbanos}

2010/2011 - desenhos - nanquim sobre papel, $21 \mathrm{~cm} \times 30 \mathrm{~cm}$

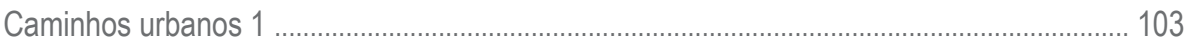

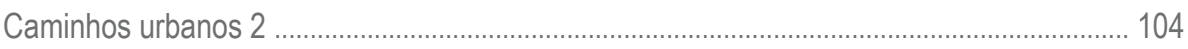

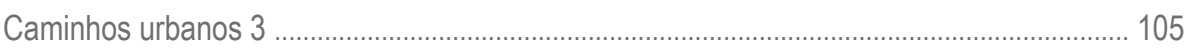

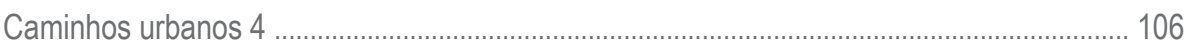

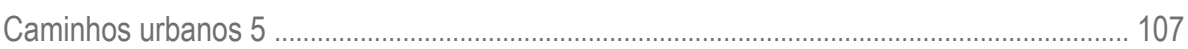

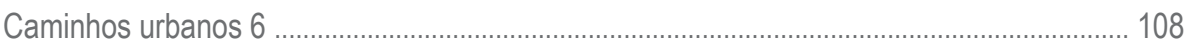

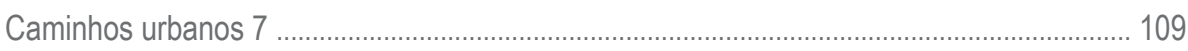

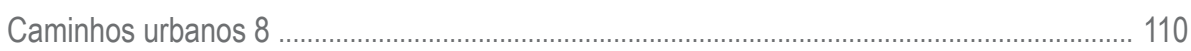

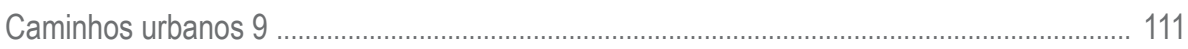

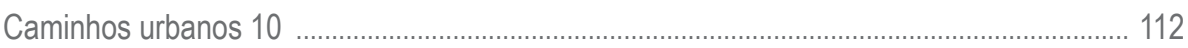

De quando em vez

2010 desenhos - letra set e nanquim sobre papel

De quando em vez I ............................................................................................................... 114

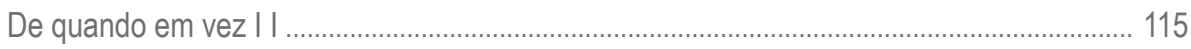

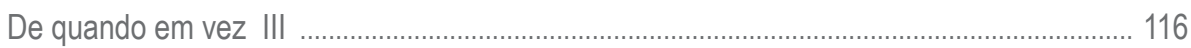

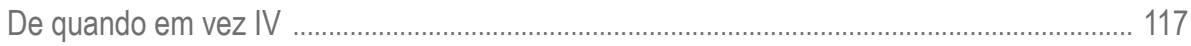

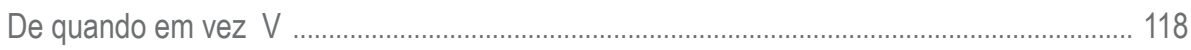


De quando em vez $\mathrm{VI}$

De quando em vez VII

De quando em vez VIII

De quando em vez IX

\section{Alinhavar sonhos}

2011, desenhos - nanquim sobre papel, $15 \mathrm{~cm} \times 21 \mathrm{~cm}$

Alinhavar sonhos 001 124

Alinhavar sonhos 002 125

Alinhavar sonhos 003 126

Alinhavar sonhos 004 127

Alinhavar sonhos 005 128

Alinhavar sonhos 006 129

\section{Percursos}

2011/2012,desenhos - nanquim sobre papel, $15 \mathrm{~cm}$ X $21 \mathrm{~cm}$

Camadas

Cantar 134

Durante 135

Conversa 136

Esquecimentos 137

Saberíamos 138

Construir 139

Cansa 140

Desvelados 141

Amainar 142

Renunciar 143

Memória 144

Mas 145

Ânforas

2011/2012 - desenhos digitais, $30 \mathrm{~cm} \times 21 \mathrm{~cm}$

Ânfora I 147

Ânfora II 148

Ânfora III 149

Ânfora IV 150

Ânfora V 151 
Ânfora VI

Ânfora VII

2011, desenho a caneta e lápis de cor, $14 \mathrm{~cm}$ X 10cm

Ânfora 155

Ânfora 156

Ânfora 157

2010/2011, desenho a nanquim e tinta permanente, $14 \mathrm{~cm} X 18 \mathrm{~cm}$

Livro de artista: conversas nas ânforas 159

Livro de artista: conversas nas ânforas 160

Livro de artista: conversas nas ânforas 161

2010/2011, desenho a nanquim e tinta permanente, $14 \mathrm{~cm} X 18 \mathrm{~cm}$

Livro de artista: Floresta 162

Livro de artista: Floresta 163

Livro de artista: Floresta 164

2011, desenho a caneta, $14 \mathrm{~cm} \times 18 \mathrm{~cm}$

Livro de artista: O Fundo do Mar 165

Livro de artista: O Fundo do Mar 166

Livro de artista: O Fundo do Mar 167

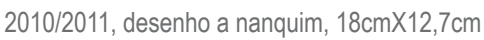

Livro de artista: Cidades 170

Livro de artista: Cidades 171

Livro de artista: Cidades 172

2011/2012, desenho a nanquim, $21 \mathrm{cmX} 14 \mathrm{~cm}$

Livro de artista: Perdidamente 174

Livro de artista: Perdidamente 175

Livro de artista: Perdidamente 176

2011/2012, desenho a nanquim, $21 \mathrm{~cm} X 13 \mathrm{~cm}$

Livro de artista: Temporalidade 177

Livro de artista: Temporalidade 178

Livro de artista: Temporalidade 179 

São Paulo | 2012 